Historic, archived document

Do not assume content reflects current scientific knowledge, policies, or practices. 

North Central

Forest Experiment

Station

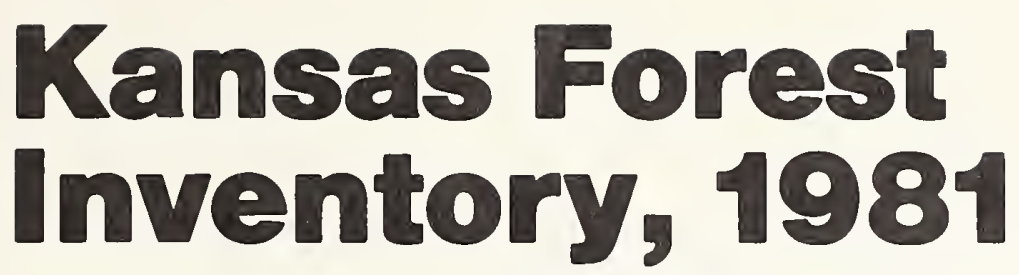

Serial Libraty

\section{Researef}

Bulletin NC-83

[4⿻肀二

John S. Spencer, Jr., John K. Strickler, and William J. Moyer

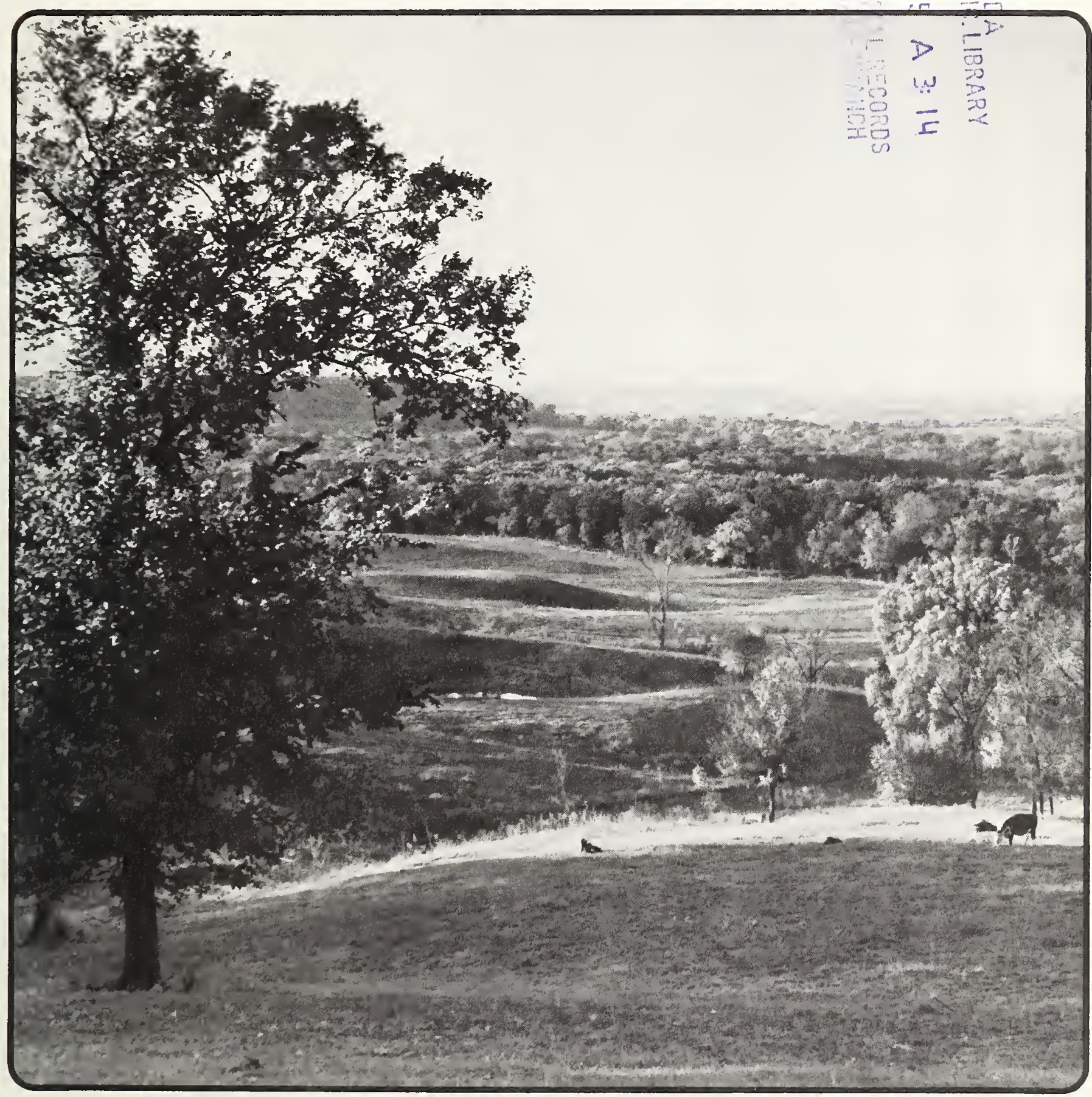

IBBAAPY

FORESTRY SCIENCES LABORATORY

P.O. EOX 909

JUNEAU, ALASKA 99302 
This report includes the most commonly used Forest Inventory and Analysis (FIA) statistics. However, additional forest resource data can be provided to interested users. Persons requesting additional information from the raw inventory data are expected to pay the retrieval costs. These costs will vary from less than $\$ 100$ for a relatively simple request to $\$ 2,000$ for a complete retrieval involving the services of a FIA computer programmer. Requests for data will be scheduled to minimize the impact on the work unit.

Requests for published, unpublished, or additional information may be directed to:

Burton L. Essex

Forest Inventory and Analysis Project

North Central Forest Experiment Station

1992 Folwell Avenue

St. Paul, Minnesota 55108

Phone: (612) 642-5275

Area served: Illinois, Indiana, Iowa, Kansas,

Michigan, Minnesota, Missouri, Nebraska,

North Dakota, eastern South Dakota, Wisconsin.

In Kansas, requests for published, unpublished, or additional information may be directed to:

State and Extension Forestry

Kansas State University

2610 Claflin road

Manhattan, Kansas 66502

Phone: (913) 532-5752

North Central Forest Experiment Station

Forest Service--U.S. Department of Agriculture

1992 Folwell Avenue

St. Paul, Minnesota 55108

Manuscript approved for publication August 24, 1984

December 1984 


\section{FOREWORD}

Forest Inventory and Analysis (formerly called Forest Survey) is a continuing endeavor as mandated by the Forest and Rangeland Renewable Resources Planning Act of 1974, which was preceded by the McSweeney-McNary Forest Research Act of 1928. Its objective is to inventory periodically the Nation's forest land to determine its extent, condition, and volume of timber, growth, and depletions. This kind of up-to-date information is essential for intelligent forest policies and programs. USDA Forest Service regional experiment stations are responsible for conducting these inventories and publishing summary reports for individual States. The North Central Forest Experiment Station is responsible for Forest Inventory and Analysis work done in Illinois, Indiana, Iowa, Kansas, Michigan, Minnesota, Missouri, Nebraska, North Dakota, eastern South Dakota, and Wisconsin.

Fieldwork for the 1981 Kansas Forest Survey was begun in October 1980 and was completed in July 1981. Reports on the two previous surveys of Kansas' timber resources are dated 1936 and 1965.

Because of intensified field sampling, more accurate survey information was obtained during the 1981 survey than otherwise would have been feasible. This was made possible through the close cooperation provided the North Central Station by State and Extension Forestry, Kansas State University. Special funding requested by the Governor and appropriated by the 1980 Kansas Legislature allowed State and Extension Forestry to provide additional personnel to intensify the field sample. State and Extension Forestry also canvassed primary woodusing plants in the State, and those results were used to help estimate the quantity of timber products harvested in Kansas.

Aerial photos used in the Kansas forest inventory were provided by the USDA Agricultural Stabilization and Conservation Service. 


\section{HIGHLIGHTS}

\section{Forest Area}

- Forest land totaled 1.4 million acres in 1981, 2.6 percent of the State's land area.

- Commercial forest area increased from 1,192 to 1,208 thousand acres between 1965 and 1981.

- Nonindustrial private parties own 96 percent of the commercial forest--farmers alone own 62 percent.

- The oak-hickory forest type leads all others with 317 thousand acres or 26 percent of the commercial area.

- Sawtimber stands are the most extensive stand-size class with 565 thousand acres or 47 percent of the commercial area.

- Stands aged 1-20 years make up the largest proportion of commercial forest ( 29 percent).

- Average site index is 62 feet.

- One-half of all commercial forest land is on deep, well-drained soils commonly found on cove sites and intermittent stream bottoms.

- Fifty percent of the commercial forest is within onefourth mile of a maintained road.

- Noncommercial forest land amounts to 151 thousand acres.

- Wooded strips amount to 150 thousand acres and windbreaks amount to 186 thousand acres.

- Wooded pasture accounted for 210 thousand acres in 1981 compared to 369 thousand acres in 1965.

\section{Timber Volume}

- Volume of growing stock increased 42 percent from 1965 to 1981, from 503 to 711 million cubic feet.

- Sawtimber volume on commercial forest land increased 31 percent from 1965 (2.0 billion board feet) to 1981 (2.6 billion board feet).

- Wooded strip land and short-log trees account for an additional 463 million board feet, making a total State volume of 3.0 billion board feet.

- Linn County contains the largest growing-stock volume, 31 million cubic feet.

- Rough, rotten, short-log, and salvable dead tree volume amounts to 216 million cubic feet.

- Cottonwood leads all species in growing-stock volume with 19 percent of the total.

- Nearly all species increased in volume between surveys, but elm growing stock decreased drastically due to Dutch elm disease--from 89 million cubic feet in 1965 to 31 million cubic feet in 1981.

- Elm sawtimber volume dropped even more significantly--from 358 million board feet in 1965 to 70 million board feet in 1981.

- Fifty-two percent of the growing-stock volume is in trees in the 14-inch diameter class and smaller.
- Average growing-stock volume per acre was $589 \mathrm{cu}$ bic feet in 1981, compared to 422 cubic feet in 1965.

- Forty-six percent of the growing-stock volume is in stands 51-80 years old.

- Black walnut growing-stock volume amounts to 58 million cubic feet, and walnut sawtimber volume is 170 million board feet.

- Volume in growing-stock trees on nonforest land (wooded strips, wooded pasıure, and windbreaks) amounts to 115 million cubic feet.

\section{Stand Conditions}

- Net annual growth of growing stock increased from 22 to 23 million cubic feet between inventories.

- Growing-stock growth rate was 3.3 percent of inventory in 1980 .

- Growing-stock net growth per acre increased from 18.5 cubic feet in 1964 to 19.2 cubic feet in 1980 .

- Sawtimber growth on commercial forest land was 64 million board feet in 1980, 2.5 percent of inventory.

- Mortality of growing-stock trees increased from 3.3 million cubic feet in 1964 to 3.8 million cubic feet in 1980.

- Disease caused 40 percent of the 1980 mortality.

\section{Timber Use}

- Growing-stock removals increased from 8.3 to 14.0 million cubic feet between inventories.

- Sawtimber removals jumped from 30.0 to 53.3 million board feet between 1964 and 1980 .

- Cottonwood accounted for the largest volume of 1980 growing-stock removals--1.9 million cubic feet.

- Timber removals of black walnut amounted to 1.3 million cubic feet in 1980, third highest among species.

- Eighty-six percent of the 1980 growing-stock removals were harvested for roundwood products, primarily fuelwood and saw logs.

- Output of fuelwood from roundwood nearly quadrupled from 1964 to 1980 --from 68 to 255 thousand cords.

- Private land supplied virtually all of the removals from growing stock.

- Growing-stock removals amounted to only 60 percent of growth in 1980.

\section{Biomass}

- Total biomass of all live trees at least 1 inch in d.b.h. averages 44 green tons per acre.

- Greatest live tree biomass density is in the cottonwood type with 77 green tons per acre. 
- Shrub biomass is greatest in the willow and eastern redcedar-hardwood forest types where it averages 2,786 and 2,767 pounds per acre green weight, respectively.

- Among the tall shrubs, roughleaf dogwood produces the greatest average biomass with 269 pounds per acre.

- Buckbrush predominates among low shrubs with an average of 129 pounds per acre.

\section{Projections}

- The low removals option projection shows inventory increasing from 711 to 1,098 million cubic feet between 1981 and 2011, a 54-percent gain. Growth is projected to remain higher than removals throughout the period but to approach removals during the last decade.

- The high removals option projection shows inventory rising from 711 to 974 million cubic feet in 2008 , then declining to 969 million cubic feet in 2011. Removals are projected to surpass growth by 2008 .

- The trend of increased fuelwood production is expected to continue. If the best young growing-stock trees are taken for fuelwood, future potential to produce quality saw logs will be greatly reduced. How ever, proper utilization of lower quality trees for fuelwood provides an opportunity for improved forest management. 


\section{CONTENTS}

Page

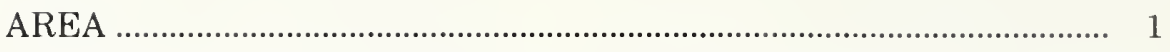

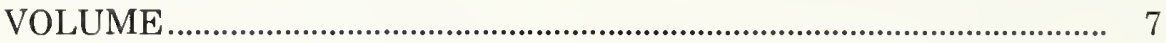

GROWTH, MORTALITY, REMOVALS AND BIOMASS.................... 13

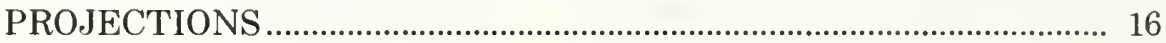

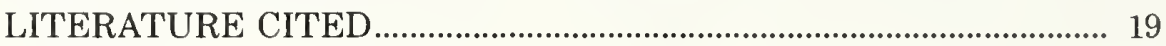

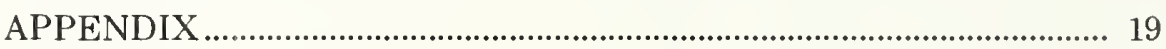

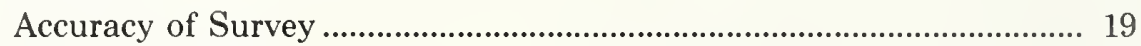

Survey Procedure .................................................................................. 20

Comparing Kansas' Third Survey with the Second Survey ................ 21

Log Grade.............................................................................................. 21

Principal Tree and Shrub Species Groups in Kansas ........................... 24

Metric Equivalents of Units Used in this Report.............................. 25

Definitions of Terms......................................................................... 25

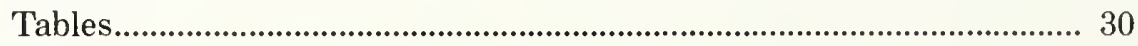




\title{
KANSAS FOREST INVENTORY, 1981
}

\author{
John S. Spencer, Jr., Principal Resource Analyst, \\ St. Paul, Minnesota \\ John K. Strickler, Associate State Extension Forester, \\ and William J. Moyer, Extension Forester, Fire Control, \\ State and Extension Forestry, \\ Kansas State University, \\ Manbattan, Kansas
}

Forest land in Kansas, more plentiful in the east and reduced to narrow stringers along rivers and streams in the west, totaled 1.4 million acres in 1981. This is a slight increase of 8,900 acres over the 1965 forest area (Chase and Strickler 1968). Although only 2.6 percent of Kansas' total land area, forests return important economic and non-commodity benefits to the State. Forest land includes commercial forest, unproductive forest, and productive-reserved forest land (see Definition of Terms in Appendix).

Probably the greatest single impact on the State's forest land between the 1965 and 1981 forest inventories was the death of many elms from Dutch elm disease--particularly the larger diameter trees. In 1965 , elm was second only to cottonwood as the most predominant species in the State; but by 1981, it had become relatively insignificant compared to a number of other species.

\section{AREA}

\section{Commercial Forest Gains $\mathbf{1 . 4}$ Percent Between Inventories}

Commercial forest area increased slightly from 1,192 to 1,208 thousand acres between $1965^{1}$ and 1981 . Onethird of the 1981 commercial area is pastured. This grazing on land for which the primary use is wood production is an obstacle to the establishment and regeneration of high-quality stands.

The largest area of commercial forest is in the Northeastern Survey Unit (588 thousand acres), followed by the Southeastern Unit (437 thousand), and the Western Unit (183 thousand) (fig. 1).

'Figures have been adjusted from those published after the 1965 survey to conform to 1981 statistics because of changes in survey definitions and procedures.
Linn County (48,700 acres) and Chautauqua County (48,500 acres), both in the Southeastern Unit, and Miami County $(46,300$ acres) in the Northeastern Unit, lead all other counties in commercial forest area. But in terms of commercial forest as a percent of total land area, Leavenworth County in the Northeastern Unit leads all others with 14.6 percent. Linn County (12.7 percent), Miami County (12.3 percent), and Jefferson County (12.0 percent) follow.

\section{Most Forest is Privately Owned}

Nonindustrial private parties own 96 percent of the commercial forest (fig. 2). Farmers alone own 62 percent of the State's commercial area, and miscellaneous private parties own another 34 percent.

Fifty-eight percent of the nonindustrial private forest land is owned by parties with 10 to 50 acres of commercial forest. Another 25 percent is owned by parties with from 50 to 500 acres, and 2 percent is owned by parties with 500 to 2,500 acres, as shown in the following tabulation. These areas represent the total area owned by an individual, and may include one or more non-continguous tracts.

$\begin{array}{cc}\begin{array}{c}\text { Size of holding } \\ \text { (Acres) }\end{array} & \begin{array}{c}\text { Area owned by nonindustrial } \\ \text { private parties } \\ \text { (Thousand acres) }\end{array} \\ 1-5 & 31.0 \\ 5-10 & 132.8 \\ 10-20 & 272.3 \\ 20-50 & 401.3 \\ 50-100 & 194.6 \\ 100-100 & 95.0 \\ 500-2,500 & 21.9 \\ 2,500-5,000 & -- \\ 5,000+ & 8.6 \\ \text { Total } & 1,157.5\end{array}$




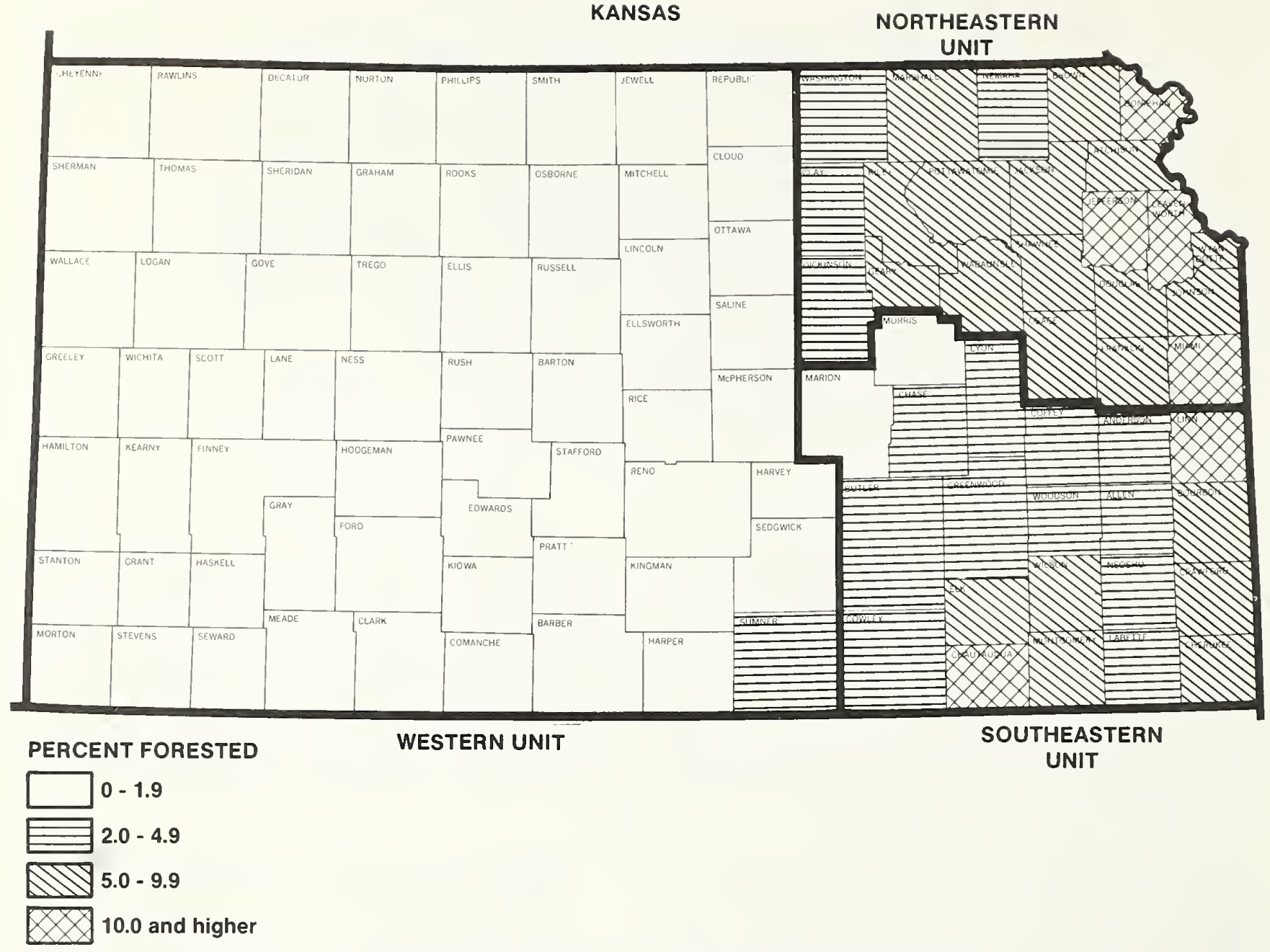

Figure 1.--Survey units in Kansas and commercial forest area as a percent of all land, by county, 1981.

\section{Oak-Hickory Type Makes Up One-quarter of Commercial Area}

The oak-hickory forest type, generally found on dry upland sites in the east, leads all others in area with 317 thousand acres (26 percent of the commercial area). This is a 71-percent increase from the 185 thousand acres in 1965. The elm-ash-cottonwood type, usually found on moist sites along stream bottoms, follows with 290 thousand acres, up 50 percent from the 193 thousand acres in 1965 (fig. 3). The lowland plains hardwood type, a mix of black walnut, hackberry, bur oak, soft maple, and boxelder generally found in coves and bottomlands, is the third largest forest type. It encompasses 266 thousand acres, a 20-percent gain over the 221 thousand acres in 1965. These three forest types together account for nearly three-fourths of the State's commercial forest area.

The upland elm-ash-locust type was the most extensive in 1965 with 229 thousand acres. But by 1981 it had declined 52 percent to 110 thousand acres, making it the fourth largest type. The high mortality rate of elm from Dutch elm disease between the two surveys undoubtedly accounts for some of the shift from the elm-ash-locust type to some of the other more predominant types in 1981. Other types that lost area between surveys include upland plains hardwoods that declined 56 percent and willow that declined 52 percent. Nonstocked area fell from 147 thousand acres in 1965 to 45 thousand acres in 1981, a 69 -percent drop. It can be assumed that increased stocking levels in many cases shifted these nonstocked acres into other types in the later survey.

\section{Sawtimber Stands Predominate}

Sawtimber stands in Kansas account for the largest area of any stand-size class--565 thousand acres or 47 percent of the total commercial area. This is slightly higher than the national average for proportion of sawtimber stands ( 45 percent), but much less than the 57 


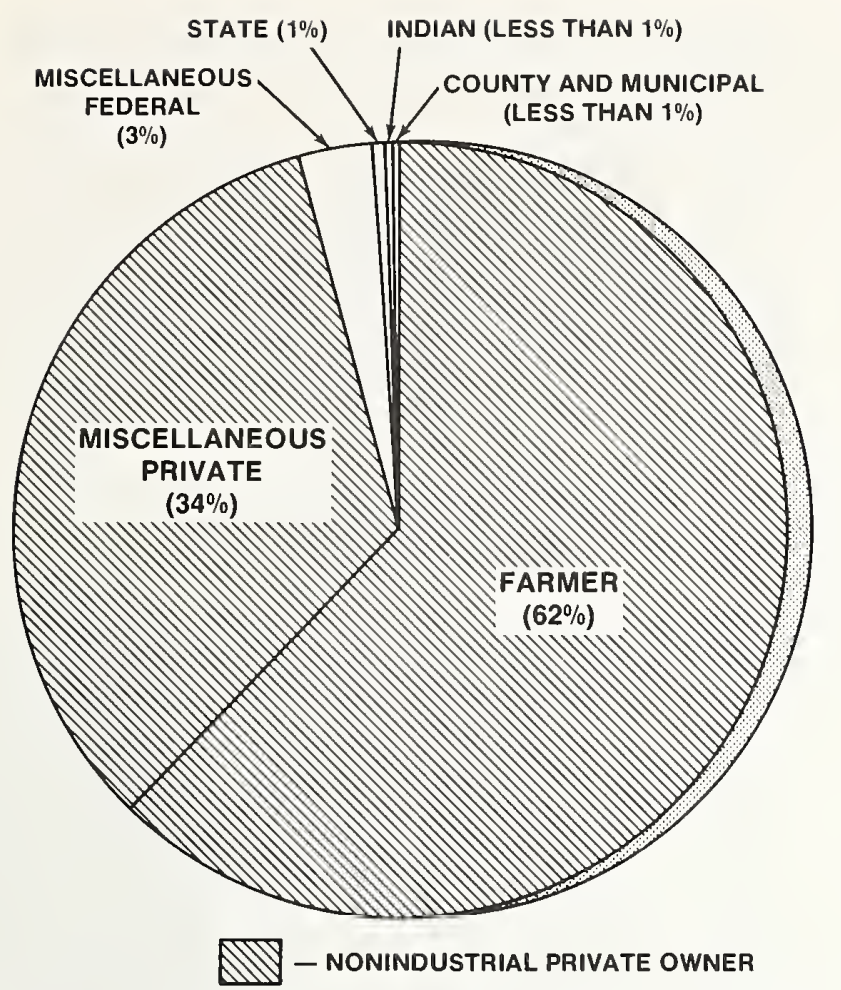

Figure 2.--Area of commercial forest land by ownership class, Kansas, 1981.

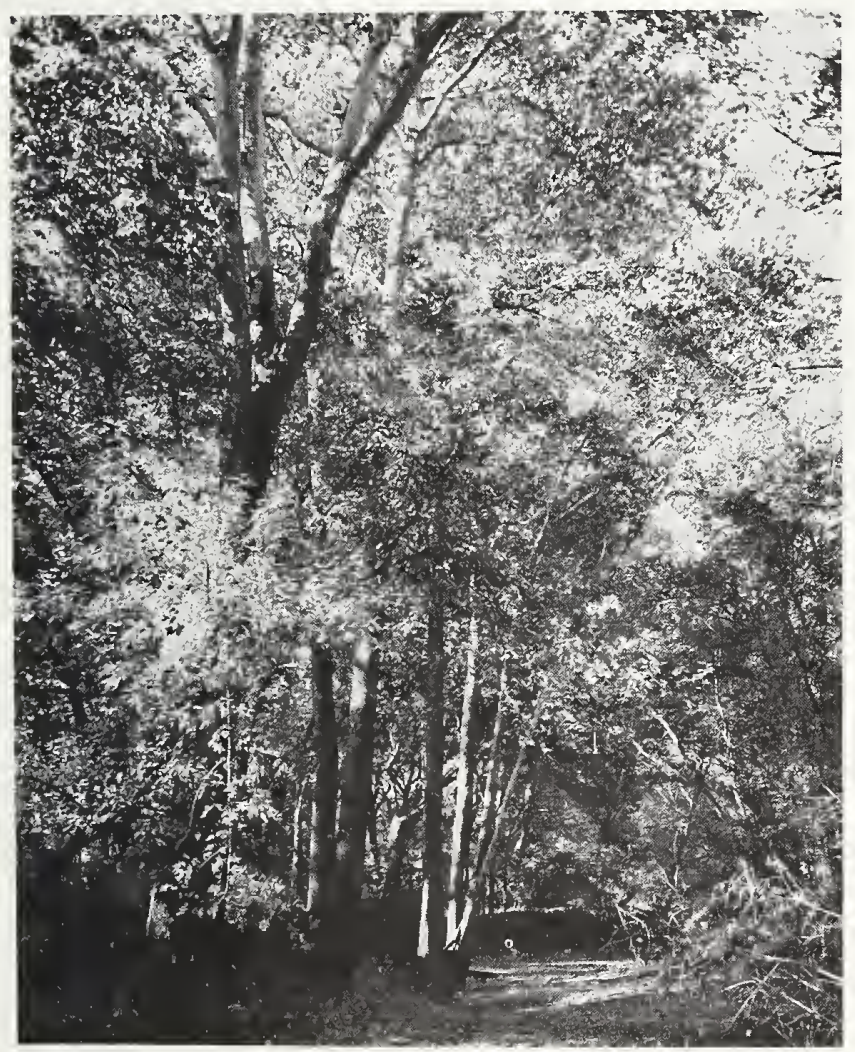

Figure 3.--Elm-ash-cottonwood forest type paralleling a dry stream bed. This type is usually found on first or second bottoms of streams. percent estimated during the 1965 Kansas inventory. This drop in sawtimber acreage can be partially explained by the death of elm sawtimber trees. Sawtimber stand acreage in the upland elm-ash-locust type dropped from 106,100 acres in 1965 to 16,800 acres in 1981.

Sapling and seedling stands, with 363 thousand acres in 1981, are the second largest stand-size class. This class represents 30 percent of the commercial forest in 1981, compared to 12 percent in 1965 . Nationwide, the average proportion of sapling and seedling stands is 24 percent of the commercial forest.

Poletimber stands account for 234 thousand acres in 1981 or 19 percent of the commercial area, the same proportion as in 1965 . Throughout the U.S., poletimber stands average 28 percent of the total commercial area.

Nonstocked areas amounted to 45 thousand acres in 1981 (4 percent of the total), a big drop from the 147 thousand acres in 1965 (12 percent).

Largest areas of sawtimber stands are in the lowland plains hardwoods type (171 thousand acres), the elmash-cottonwood type (145 thousand acres), and the oak-hickory type (142 thousand acres). But the highest proportion of any forest type in sawtimber stands is the 88 percent of the cottonwood type. The eastern redcedar-hardwood type, which increased in area from 2.7 to 27.5 thousand acres between surveys, contains 80 percent of its area in sapling and seedling stands-highest of any type.

\section{Largest Area in Stands Aged 1-20 Years}

The distribution of commercial forest by stand-age class shows more area aged 1-20 years and less area aged 21-50 years (fig. 4). Stands 11-20 years old are most numerous with 193 thousand acres or 16 percent of the commercial forest area, and stands aged 1-10 years follow with 155 thousand acres or 13 percent of the total. Together, these two classes generally represent the new stands established since the last survey.

An ideal distribution of age classes from a forest management perspective is an equal area in each 10year class through the rotation age ${ }^{2}$ of the particular forest type and no area in classes beyond rotation age. The diminished area of stands 21-50 years old means a future shortage of mature timber in some forest types when they reach rotation age--primarily the elm-ashcottonwood and lowland plains hardwoods types.

${ }^{2}$ Rotation age is the period of years required to establish and grow timber crops to a specified condition of maturity. 


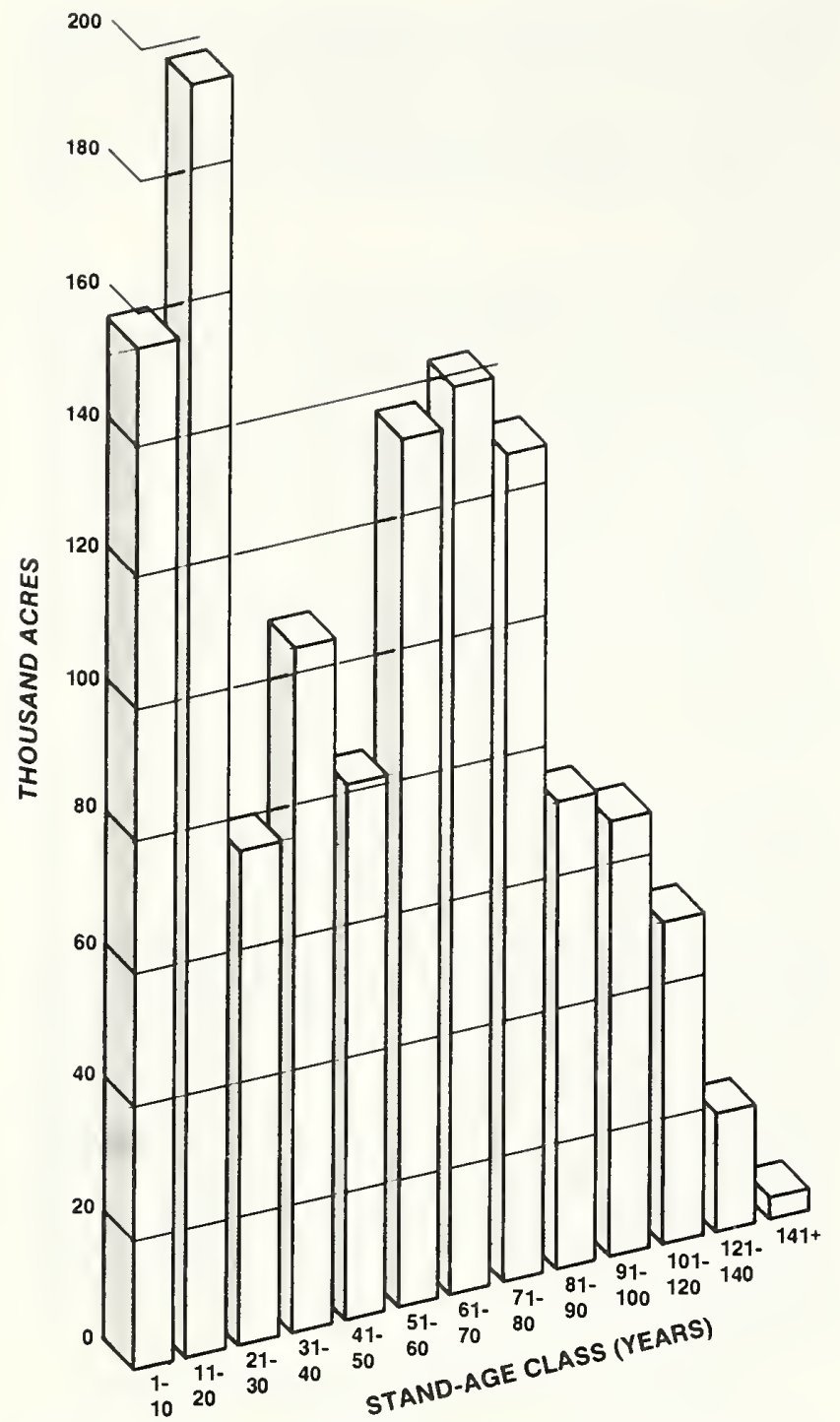

Figure 4.--Area of commercial forest land by stand-age class, Kansas, 1981.

However, this imbalance in age classes is not strongly reflected in the diameter distribution of growing-stock trees of several desirable species such as ash, black walnut, and hackberry. Comparisons of the growing-stock diameter distribution for number of trees or cubic foot volume would indicate an opportunity to offset much of the effects of this age imbalance through improved forest management to favor these desirable species.

\section{Average Site Class Highest of Plains States}

Site class is one means of estimating forest site quality. Site class describes forest land in terms of its inherent capacity to grow wood based on fully stocked

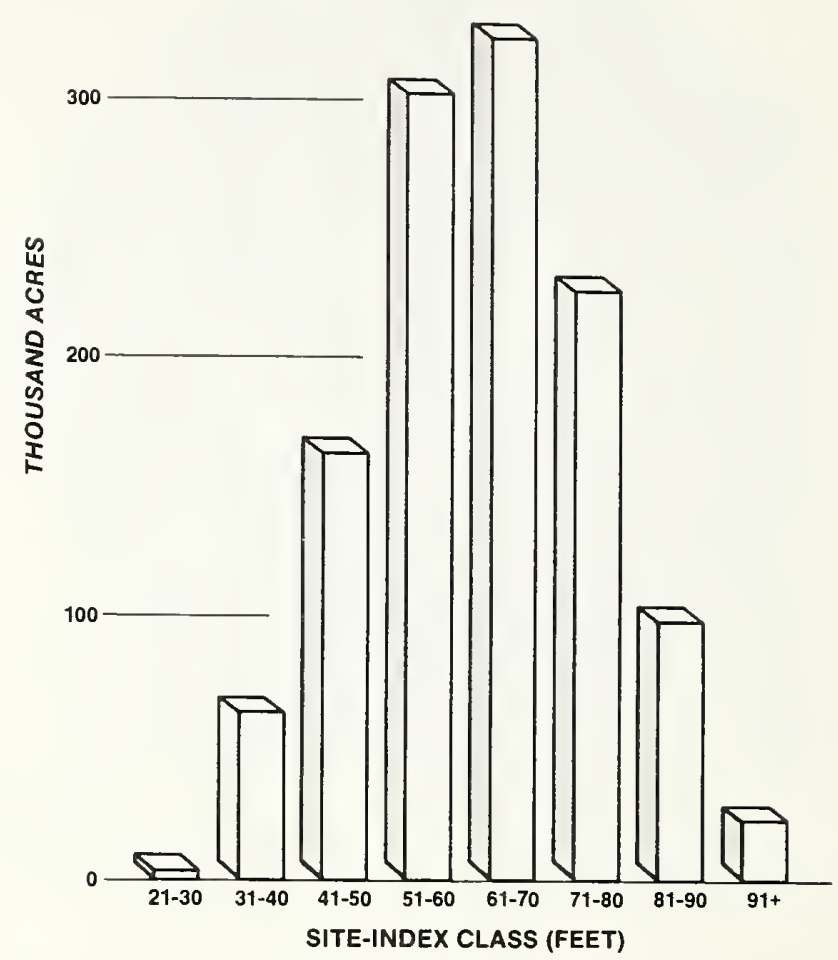

Figure 5.--A rea of commercial forest land by site-index class, Kansas, 1981.

natural stands. Site class values are the cubic feet of growth per acre per year expected from such stands.

The weighted average site class for Kansas is 56.8 cubic feet of growth per acre per year, compared to a weighted average for the Plains States ${ }^{3}$ of 54.1. (Commercial forest land can produce more than 20 cubic feet per acre of annual growth under management.)

\section{Average Site Index is $\mathbf{6 2}$ Feet}

Another way of estimating forest site quality is through use of site index information. Site index is a means of classifying forest land in terms of height growth of dominant or codominant trees of representative species within a forest type at 50 years of age. Eighty-one percent of the commercial forest area (979 thousand acres) grows trees taller than 51 feet at age 50 , and 29 percent of the total grows trees taller than 71 feet (fig. 5).

${ }^{3}$ In this paper the Plains States are considered to be North Dakota, eastern South Dakota (east of the 103rd meridian), Nebraska, and Kansas. 
Site index values differ by forest type. A high value for one type may be a low value for another type. The weighted average site index for all types is 62.2 feet. The highest weighted average is 67.5 feet for the lowland plains hardwoods type, followed by elm-ash-cottonwood (66.9 feet), upland plains hardwoods (64.3 feet), cottonwood (64.1 feet), and willow (64.0 feet). The lowest weighted average is the 45.2 feet in the eastern redcedar-hardwood type.

\section{Half of Area on Deep, Well-drained Soils}

Yet another way forest site quality can be appraised is by considering the area in each physiographic class. Physiographic class is a measure of soil and water conditions on a site that affect tree growth. The five classes range from exceptionally wet sites (hydric) to very dry sites (xeric). Best growing conditions for most species are in the class midway between these two extremes (mesic). Mesic sites are the deep, well-drained soils commonly found on cove sites and bottomlands along intermittent streams. One-half of the commercial forest area is on mesic sites, including 79 percent of the lowland plains hardwoods type, 70 percent of the elm-ash-cottonwood type, and 42 percent of the oak-hickory type (table 1).

\section{Stocking Could be Improved}

The stocking picture varies greatly depending upon whether only growing-stock trees or all live trees are considered. When all live trees, including rough and rotten trees and noncommercial species are considered, the area of commercial forest land at least medium stocked (61 percent stocked or better) is $1,035,000$ acres or 86 percent of the total. This represents little change from 1965 when 1,014,000 acres (85 percent) were medium or better stocked with all live trees.

When only growing-stock trees are considered, the stocking situation has improved decidedly. Commercial forest acreage medium or better stocked with growing-stock trees increased from 161,500 acres (14 percent) in 1965 to 639,200 acres (53 percent) in 1981. Of this total, 95,000 acres are well stocked with growing-stock trees. The remainder of the commercial forest is either poorly stocked with growing-stock trees (523,300 acres) or nonstocked (45,400 acres).

Still, the 47 percent of commercial forest land poorly stocked or nonstocked with growing-stock trees represents a less than desirable situation. This land could produce trees much more efficiently if better stocked. Stocking is poorest in sapling and seedling stands where 57 percent of the area is poorly stocked with growing-stock trees. A larger proportion of the upland elm-ash-locust forest type is poorly stocked (66 percent) than any other type, although the eastern redcedar-hardwood (58 percent) and upland plains hardwoods types (58 percent) follow closely.

\section{Half of Forest Within One-quarter Mile of Road}

Fifty percent of the commercial forest area in Kansas is within one-fourth mile of a maintained road (one

Table 1.--Area of commercial forest land by forest type and physiographic class, Kansas, 1981

(In thousand acres)

\begin{tabular}{|c|c|c|c|c|c|c|}
\hline \multirow[b]{2}{*}{ Forest type } & \multicolumn{6}{|c|}{ Physiographic class } \\
\hline & $\begin{array}{c}\text { All } \\
\text { classes }\end{array}$ & Hydric & $\begin{array}{l}\text { Hydro- } \\
\text { mesic }\end{array}$ & Mesic & $\begin{array}{l}\text { Xero- } \\
\text { mesic }\end{array}$ & Xeric \\
\hline Eastern redcedar-hardwood & 27.5 & -- & -- & 2.4 & 25.1 & -- \\
\hline Oak-hickory & 316.6 & 2.6 & 7.6 & 132.7 & 155.5 & 18.2 \\
\hline Post-blackjack oak & 30.9 & -- & 1.2 & 9.8 & 17.6 & 2.3 \\
\hline Upland plains hardwoods & 49.4 & -- & -- & 1.2 & 46.5 & 1.7 \\
\hline Elm-ash-cottonwood & 289.6 & 9.0 & 77.1 & 203.5 & -- & -- \\
\hline Cottonwood & 68.1 & 3.9 & 20.2 & 29.9 & 6.9 & 7.2 \\
\hline Willow & 4.2 & -- & 3.4 & -- & 0.8 & -- \\
\hline Lowland plains hardwoods & 265.9 & 2.5 & 52.3 & 211.1 & -- & -- \\
\hline Upland elm-ash-locust & 110.3 & -- & -- & -- & 100.5 & 9.8 \\
\hline Nonstocked & 45.4 & 9.1 & 3.0 & 11.5 & 19.7 & 2.1 \\
\hline All types & $1,207.9$ & 27.1 & 164.8 & 602.1 & 372.6 & 41.3 \\
\hline
\end{tabular}


graded at least once a year), and 96 percent of it is within 1 mile of a road:

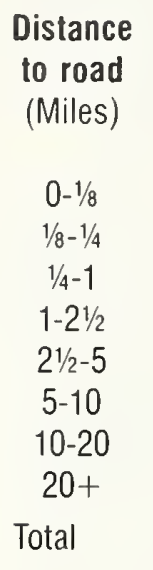

\section{Area of commercial forest land (Thousand acres)}

\begin{tabular}{c}
240.2 \\
363.8 \\
560.2 \\
19.3 \\
16.1 \\
-- \\
8.3 \\
-- \\
\hline $1,207.9$
\end{tabular}

30

46

2

1

$--$

1

100

\section{One-fifth of Forest Within Quarter Mile of Open Water}

Proximity of timber to open water may affect its suitability for harvest because of multiple use (primarily wildlife and recreation, and accessibility considerations. Twenty-one percent of the State's commercial forest area is within one-fourth mile of a lake or pond at least 5 acres in area or a stream at least 66 feet wide. Fourteen percent is within oneeighth mile of open water:

\begin{tabular}{|c|}
\hline $\begin{array}{l}\text { ater } \\
\text { iles) }\end{array}$ \\
\hline $0-1 / 8$ \\
\hline $1 / 8-1 / 4$ \\
\hline $1 / 4-1$ \\
\hline $1-2^{1 / 2}$ \\
\hline $2^{1 / 2-5}$ \\
\hline $5-10$ \\
\hline $10-20$ \\
\hline $20+$ \\
\hline Total \\
\hline
\end{tabular}

\begin{tabular}{c} 
Area of commercial \\
forest land \\
(Thousand acres) \\
169.4 \\
81.0 \\
201.2 \\
211.6 \\
167.6 \\
106.6 \\
111.5 \\
159.0 \\
\hline $1,207.9$
\end{tabular}

Percent 14

\section{Noncommercial Forest Land Amounts to 150,800 Acres}

Kansas also has two kinds of forest land on which industrial wood is not harvested: unproductive forest (128,400 acres) and productive-reserved forest land (22,400 acres).

All of the unproductive forest is owned by farmers and miscellaneous private parties, and most is in the post-blackjack oak type (59 percent), the eastern redcedar-hardwood type (13 percent), and the oak-hickory type (10 percent).
The productive-reserved forest land, which includes Christmas tree plantations, is primarily owned by public agencies. The oak-hickory type (44 percent) and the eastern redcedar-hardwood type (33 percent) account for most of the productive-reserved area.

\section{Wooded Strips and Windbreaks-- An Important Resource}

The area of nonforest land with trees $(1,189$ thousand acres) almost equals the area of commercial forest land in the State. Trees are usually very sparse on this category of land except on wooded strips and windbreaks.

Wooded strips amount to 150,000 acres in Kansas (fig. 6). Most of these strips are in the elm-ash-cottonwood type $(51,600$ acres $)$ and the lowland plains hardwoods type (49,900 acres), and almost all are owned by private parties. Only 10 percent of the area is in sawtimber stands, and almost equal amounts are in poletimber ( 39 percent) and sapling and seedling stands (38 percent). Sixty-one percent of the wooded strip area supports stands aged 30 years or less and 73 percent supports stands 40 years old and younger. The significance of wooded strips is indicated by the 92 million cubic feet of growing-stock trees and the 315 million board feet of sawtimber and short-log trees they contain. Although small tract size sometimes imposes constraints on logging, these wooded strips are frequently logged in conjunction with adjacent commercial land.

Windbreaks total 186,300 acres in the State (fig. 7). Because their primary purpose is protection from wind, these windbreaks are of little significance for timber supply except for occasional firewood cuttings. Windbreaks are more numerous in the Western Unit (76,400 acres), compared with the Southeastern Unit $(66,900$ acres) and the Northeastern Unit $(43,000$ acres). Both wooded strips and windbreaks are important habitat for wildlife.

One other significant class of nonforest land with trees is wooded pasture--grazed land with more than 16.7 percent stocking in live trees, but less than 25 percent stocking in growing-stock trees. In 1981, wooded pasture accounted for 210,000 acres--a 43-p. . cent drop from 369,000 acres in 1965 . Some of the wooded pasture acreage in 1965 may have shifted into the commercial forest acreage because of the increased growth and stocking of growing-stock trees. For example, this might account for the increase in acreage of the eastern redcedar-hardwood type from 2.7 to 27.5 thousand acres between surveys. 


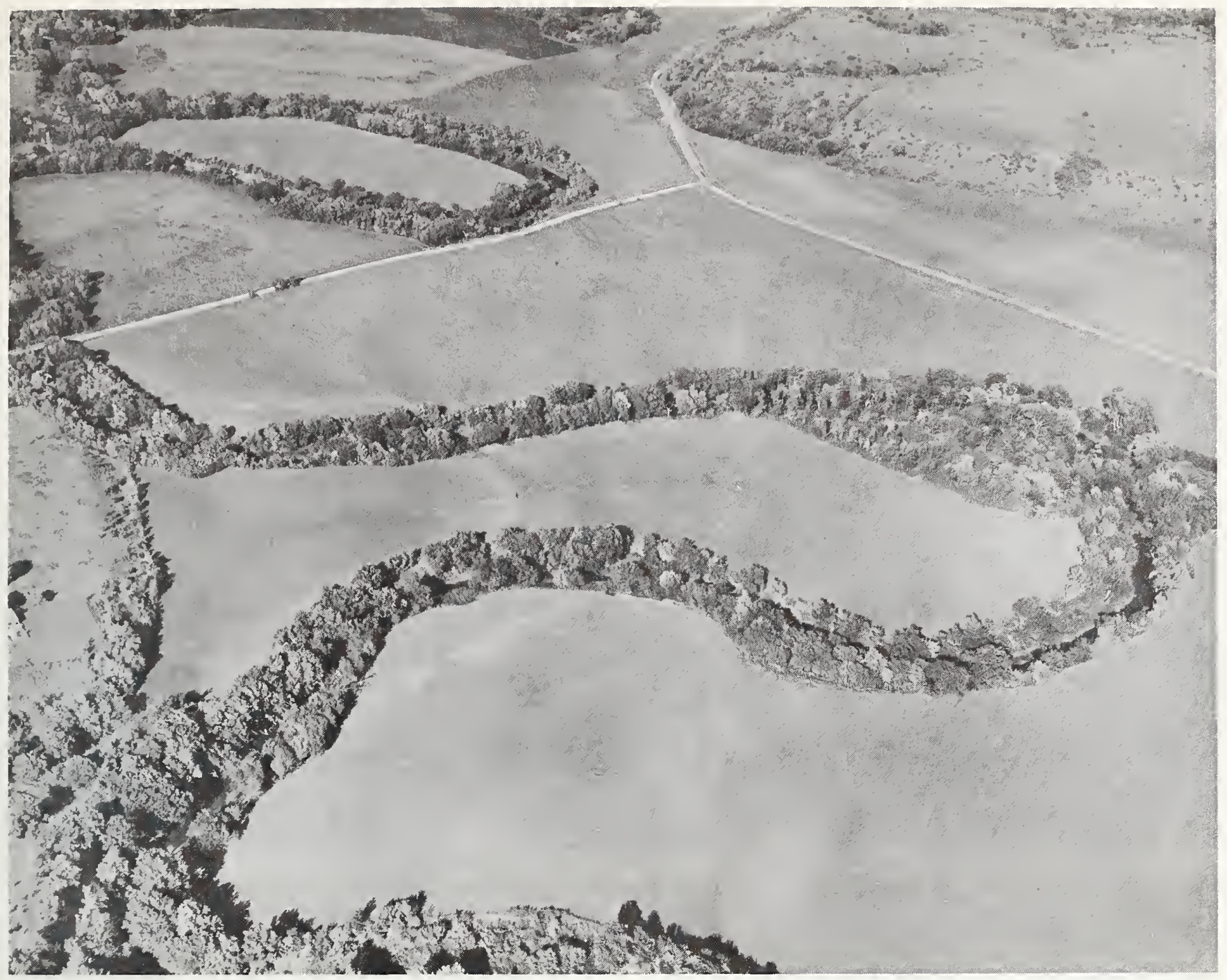

Figure 6.--Wooded strips, like these following a meandering stream, are land that meets all the requirements for commercial forest land except that it supports trees in stands less than 120 feet wide.

\section{VOLUME}

\section{Timber Volume Shows Substantial Gain Between Inventories}

Volume of growing stock on commercial forest land in Kansas increased 42 percent between 1965 (503 million cubic feet) and 1981 (711 million cubic feet). The continuing surplus of growth over timber removals between inventories causes these building inventory volumes.

The minor softwood growing-stock volume, which is entirely eastern redcedar, had surged to 21 times its 1965 volume by 1981 . Hardwood volume, which accounts for 99 percent of the growing-stock total, gained 41 percent between inventories:

\begin{tabular}{ccr} 
Species & \multicolumn{2}{c}{ Growing-stock volume } \\
\cline { 2 - 3 } group & 1965 & 1981 \\
& (Thousand & cubic feet) \\
Softwoods & 216 & 4,591 \\
Hardwoods & $\underline{502,384}$ & $\underline{706,724}$ \\
Total & 502,600 & 711,315
\end{tabular}

Sawtimber volume on commercial forest land increased 31 percent, from 2.0 billion board feet ${ }^{4}$ in 1965 to 2.6 billion in 1981. Softwood sawtimber volume showed an extraordinary expansion similar to the softwood growing-stock volume, but hardwoods showed a more modest gain:

${ }^{4}$ International $1 / 4-$ inch rule. 


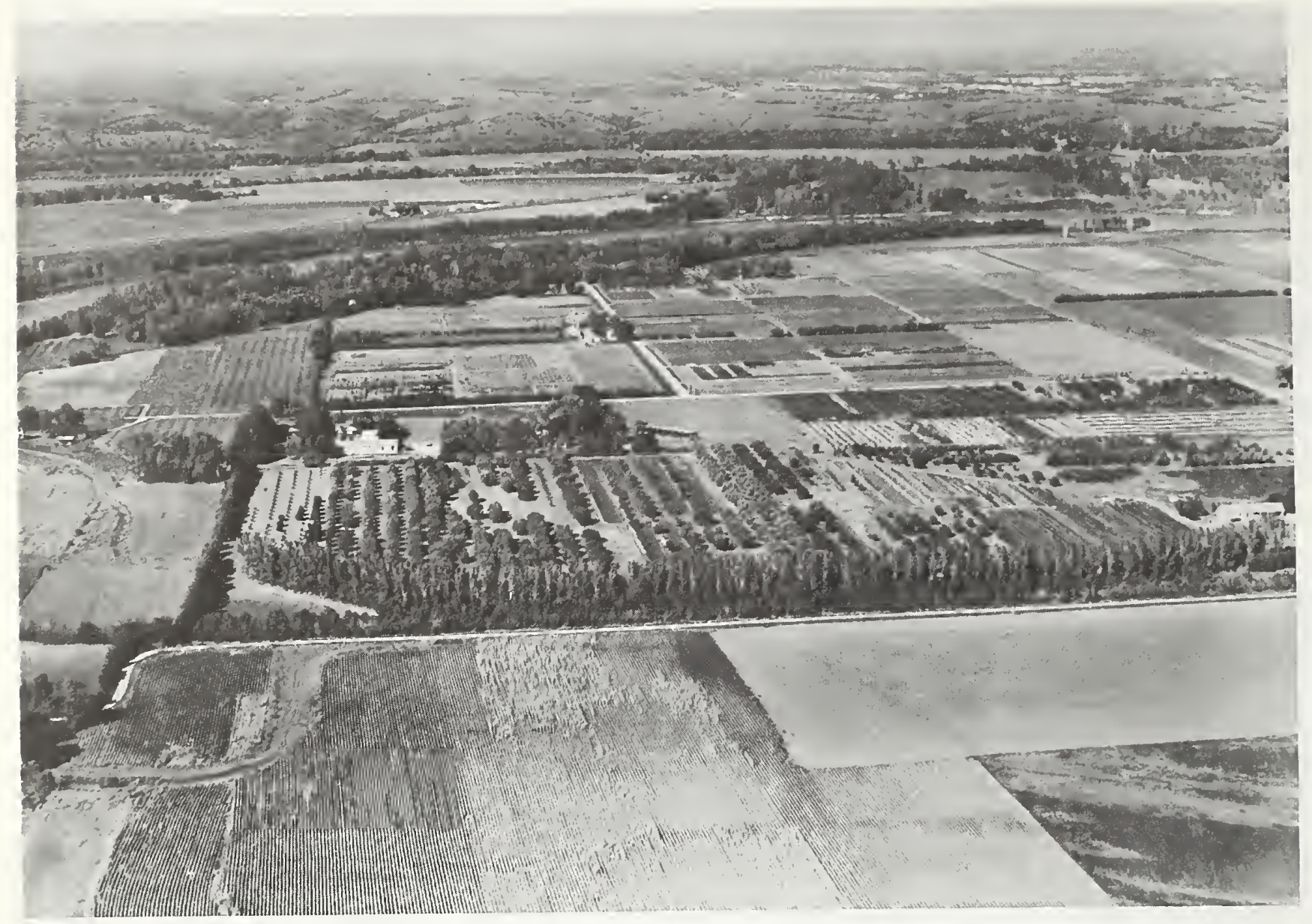

Figure 7.--Windbreaks, like the one above, are trees planted in strips less than 120 feet wide, used for protecting soil, fields, and buildings.

\begin{tabular}{|c|c|c|}
\hline \multirow{2}{*}{$\begin{array}{l}\text { Species } \\
\text { group }\end{array}$} & \multicolumn{2}{|c|}{ Sawtimber volume } \\
\hline & 1965 & 1981 \\
\hline & \multicolumn{2}{|c|}{ (Million board feet) } \\
\hline $\begin{array}{l}\text { Softwoods } \\
\text { Hardwoods }\end{array}$ & $\begin{array}{r}0.5 \\
1,953.0\end{array}$ & $\begin{array}{r}10.9 \\
2,555.3 \\
\end{array}$ \\
\hline Total & $1,953.5$ & $2,566.2$ \\
\hline
\end{tabular}

The Northeastern Survey Unit contains the largest growing-stock volume in the State. However, the Western Unit, which has the smallest volume of the three Survey Units, showed the greatest percent of increase between inventories (table 2).

Table 2.--Net volume of growing stock and sawtimber in 1965 and 1981 by Forest Survey Unit and change since 1965, Kansas

\begin{tabular}{|c|c|c|c|c|c|c|}
\hline \multirow[t]{2}{*}{$\begin{array}{c}\text { Forest Survey } \\
\text { Unit }\end{array}$} & \multicolumn{2}{|c|}{$\begin{array}{c}\text { Growing-stock } \\
\text { volume }\end{array}$} & \multirow{2}{*}{$\begin{array}{l}\text { Change } \\
\text { since } \\
1965\end{array}$} & \multicolumn{2}{|c|}{$\begin{array}{c}\text { Sawtimber } \\
\text { volume }\end{array}$} & \multirow{2}{*}{$\begin{array}{c}\text { Change } \\
\text { since } \\
1965 \\
\end{array}$} \\
\hline & 1965 & 1981 & & 1965 & 1981 & \\
\hline & \multicolumn{2}{|c|}{ Thousand cubic feet } & Percent & \multicolumn{2}{|c|}{ Thousand board feet } & Percent \\
\hline $\begin{array}{l}\text { Northeastern } \\
\text { Southeastern } \\
\text { Western }\end{array}$ & $\begin{array}{r}233,033 \\
188,375 \\
81,192 \\
\end{array}$ & $\begin{array}{l}315,093 \\
249,128 \\
147,094 \\
\end{array}$ & $\begin{array}{l}+35 \\
+32 \\
+81 \\
\end{array}$ & $\begin{array}{l}879,200 \\
738,579 \\
335,767 \\
\end{array}$ & $\begin{array}{r}1,107,613 \\
828,546 \\
630,070 \\
\end{array}$ & $\begin{array}{l}+26 \\
+12 \\
+88 \\
\end{array}$ \\
\hline Total & 502,600 & 711,315 & +42 & $1,953,546$ & $2,566,229$ & +31 \\
\hline
\end{tabular}

'International $1 / 4$-inch rule. 
Linn County, with 31 million cubic feet, contains the largest growing-stock volume among counties, followed by Leavenworth ( 28 million cubic feet), Miami (26 million), Chautauqua (24 million), Bourbon (23 million), and Pottawatomie (22 million) (fig. 8).

\section{Nongrowing-stock Volume is 216 Million Cubic Feet}

In addition to the volume in growing-stock trees discussed thus far, rough and rotten, short-log, and salvable dead tree volume adds another 216 million cubic feet. Total volume on commercial forest land in Kansas, then, is 927 million cubic feet (table 3).

The volume in short-log trees is 148 million board feet, which brings total sawtimber volume on commercial forest land to 2,714 million board feet in the State. The volume in sawtimber trees and short-log trees on wooded strips adds another 315 million board feet, bringing the total volume to 3,029 million board feet.
Table 3.--Net volume of timber on commercial forest land by class of timber and softwoods and hardwoods, Kansas, 1981

(In million cubic feet)

\begin{tabular}{lrcr}
\hline Class of timber & $\begin{array}{c}\text { All } \\
\text { spe- } \\
\text { cies }\end{array}$ & Softwoods & Hardwoods \\
\hline Growing stock & & & \\
$\quad$ Sawtimber & 490.8 & 1.9 & 488.9 \\
Poletimber & 220.5 & 2.7 & 217.8 \\
\cline { 2 - 4 }$\quad$ Total growing stock & 711.3 & 4.6 & 706.7 \\
Rough and rotten cull & 143.8 & 0.5 & 143.3 \\
Short-log cull & 67.4 & 0.4 & 67.0 \\
Salvable dead & 4.5 & 0.1 & 4.4 \\
\cline { 2 - 4 }$\quad$ All classes & 927.0 & 5.6 & 921.4 \\
\hline
\end{tabular}

\section{KANSAS}

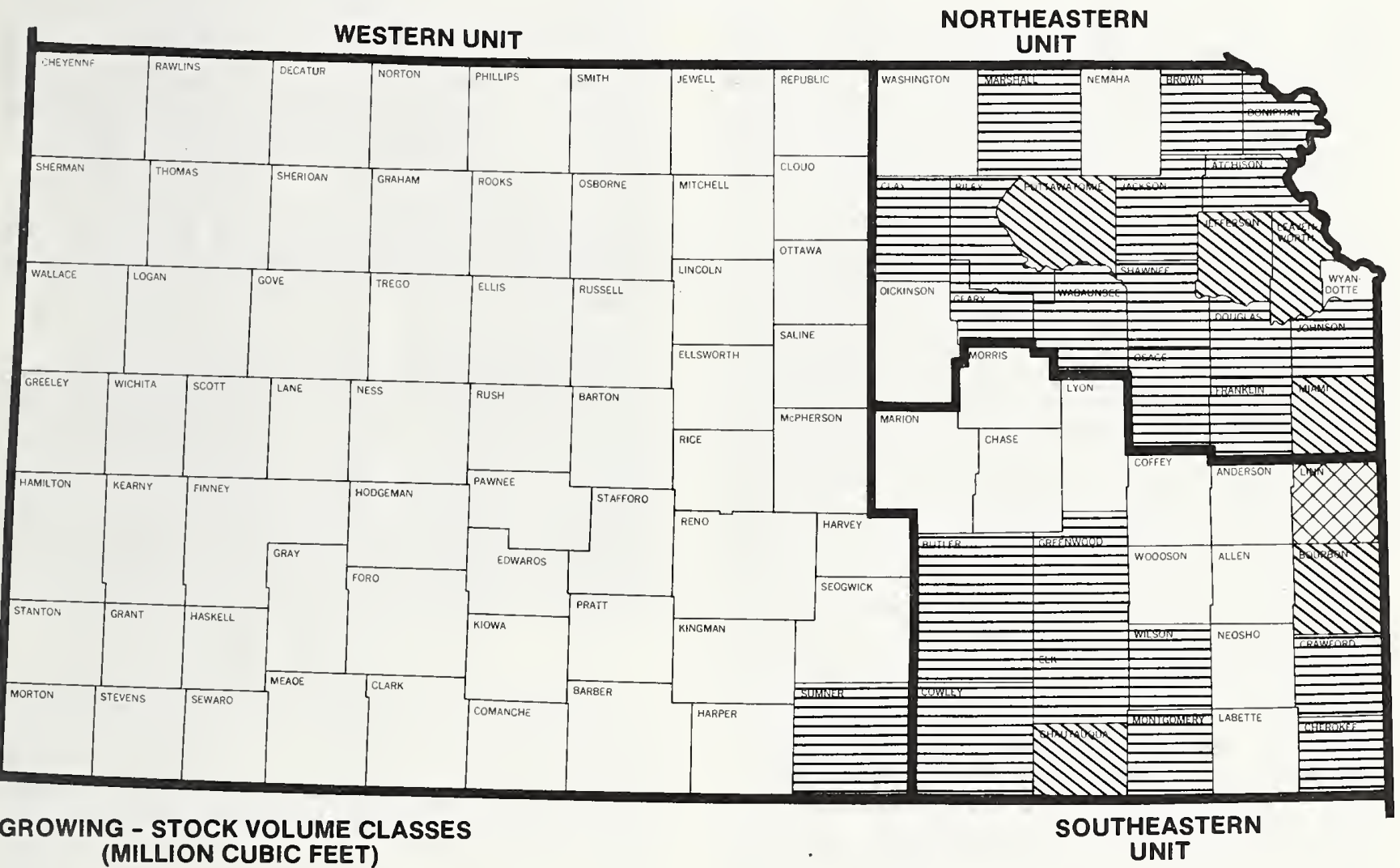

$30+$

20-30

10-20

0-10

Figure 8.--Growing-stock volume in Kansas counties, 1981. 
Although cull and salvable dead trees take up space that could be used by potentially more valuable growing-stock trees, some of them provide homes for cavity-nesting birds and other wildlife. And many of these trees can be used for timber products such as saw logs or bolts and fuelwood.

\section{Cottonwood First in Growing-stock Volume with One-fifth of Total}

In both 1965 and 1981, cottonwood led all other species in growing-stock and sawtimber volumes. The 134 million cubic feet of cottonwood represents 19 percent of the total growing-stock volume on commercial forest land in 1981 and is a 33-percent increase over the 1965 cottonwood growing-stock volume. In 1965, elm was second only to cottonwood in both growing-stock and sawtimber volumes, with a large concentration of volumes in the larger, overmature trees most susceptible to Dutch elm disease. The decimation of elm by the disease between the two surveys--elm growingstock volume decreased from 89 to 31 million cubic feet--caused a reordering of volume rankings except for cottonwood. Hackberry moved up to second in 1981 with 87 million cubic feet, a 77-percent gain over its 1965 volume of 49 million cubic feet when it ranked third behind cottonwood and elm. Ash (62 million cubic feet), bur oak (61 million), and black walnut ( 58 million) are other species with large volumes. Black walnut, highly valued and in great demand for furniture, cabinets, gun stocks and other high-quality products, increased 57 percent from its 1965 volume of 37 million cubic feet. Sycamore was the only other species besides elm to decline in volume between surveys--a much more modest decline from 25 to 22 million cubic feet. Select white oaks (see Principal Tree and Shrub Species Groups in Kansas in Appendix) made the largest proportional increase between inventories, almost tripling from 12 to 34 million cubic feet.

The order of species by sawtimber volume is somewhat different from that of growing stock. Cottonwood dominates with 24 percent of the total, expanding from 459 million board feet in 1965 to 610 million board feet in 1981. Hackberry contains the second largest sawtimber volume, with 300 million board feet. Bur oak ranks third in sawtimber volume with 286 million board feet, ash is fourth with 186 million board feet, and select red oaks are fifth with 183 million board feet. Black walnut volume follows with 170 million board feet. As might be expected from its 1965 concentration of volume in the larger diameters, elm sawtimber volume plunged even more sharply than growing-stock volume--from 358 to 70 million board feet between inventories.
Nonindustrial private owners account for 94 percent of the growing-stock volume. Farmers clearly dominate with 60 percent of the total, and miscellaneous private parties own 34 percent of the volume. Public agencies own the remaining 6 percent.

\section{Half of Growing-stock Volume in Trees 14 Inches in Diameter and Smaller}

Fifty-two percent of the State's 1981 volume of growing stock is in trees in the 14 -inch diameter class and smaller (fig. 9). There are no gaps in total growingstock volume between succeeding diameter classes that might cause future supply problems, although uneven volumes by diameter class may pose problems in the future supply of certain species--especially soft maple, basswood and sycamore. Nineteen percent of the volume is in trees 24 inches in diameter and greater, due largely to the high proportions of cottonwood and bur oak volumes in these bigger trees. Fortyfour percent of the total cottonwood volume and 38 percent of the bur oak volume are in these larger trees. Sixty-four percent of the cumulative growing-stock volume of ash, hackberry, and black walnut--among the 5 species with the greatest volumes--is in diameter classes 14 inches and smaller. The proportion in these classes is 76 percent for black walnut.

The 1981 growing-stock volumes are greater than the 1965 volumes in each diameter class, as shown in figure 9 .

Average volume per acre of growing stock on commercial forest land in 1981 was 589 cubic feet compared to 422 cubic feet in 1965 . Average volume per acre was highest in the cottonwood forest type $(1,397$ cubic feet), followed by the lowland plains hardwoods type (672), oak-hickory type (612), elm-ash-cottonwood type (596), and the post-blackjack oak type (555).

The average sawtimber volume per acre in 1981 was 2,125 board feet compared to 1,640 board feet in 1965 . The cottonwood type leads by an even wider margin than for growing stock, averaging 6,024 board feet per acre, followed by lowland plains hardwood $(2,564$ board feet), elm-ash-cottonwood $(2,162)$, and oakhickory $(2,114)$.

Three-quarters of the total growing-stock volume is in three forest types--oak-hickory (27 percent), lowland plains hardwoods ( 25 percent), and elm-ash-cottonwood (24 percent). 


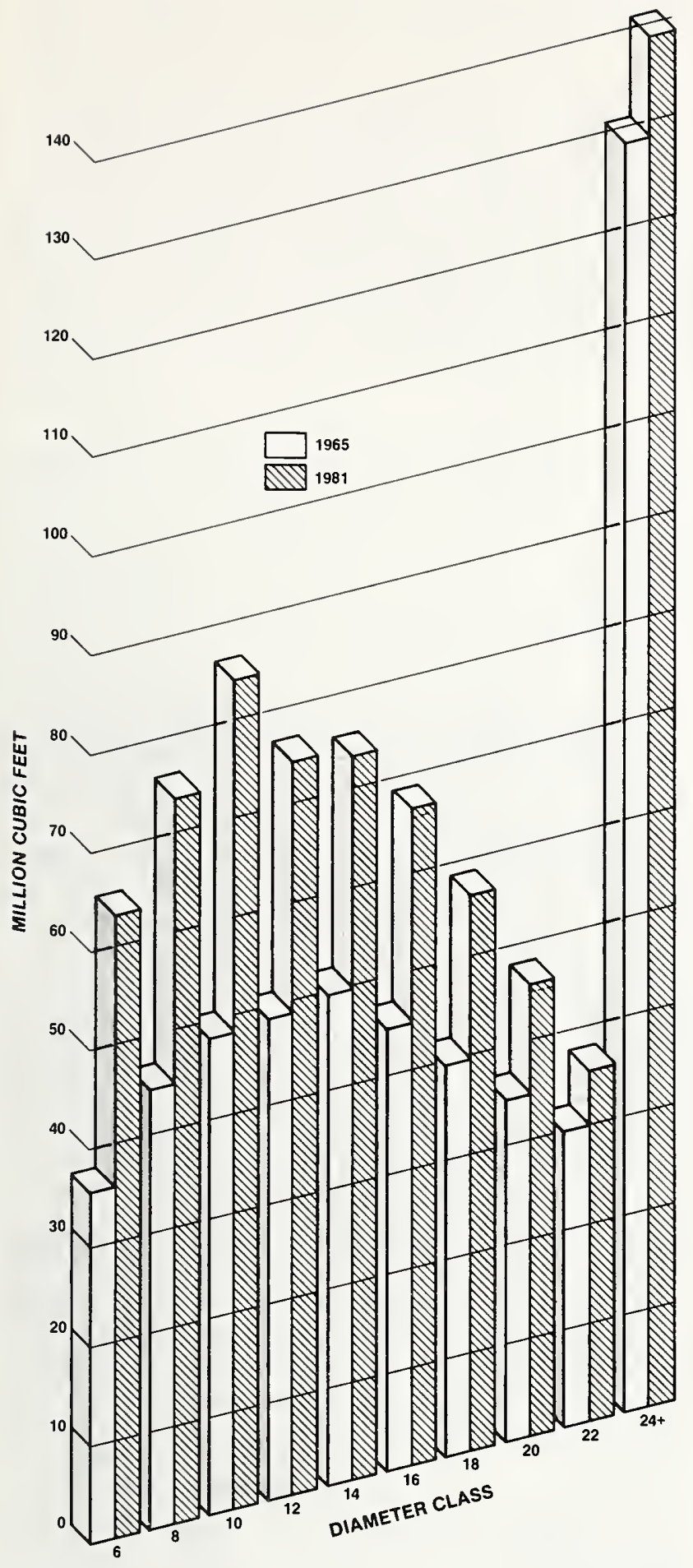

Figure 9.--Net volume of growing stock on commercial forest land, by diameter class, Kansas, 1965 and 1981.

\section{Largest Volume in Stands Aged 51-80 Years}

Forty-six percent of the total growing-stock volume is concentrated in stands $51-80$ years old (fig. 10). This

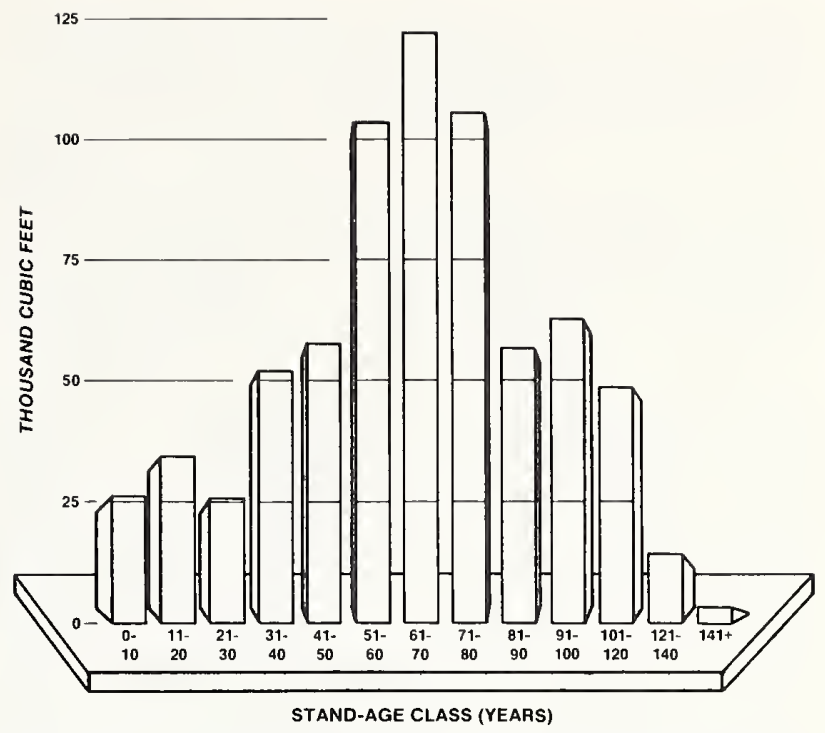

Figure 10.--Net volume of growing stock on commercial forest land by stand-age class, Kansas, 1981.

bulge corresponds to a similar bulge in the area of commercial forest land for those stand-age classes. These stands, which originated between 1901 and 1930, were among the first to become established as the public became more aware of its forests.

\section{Sawtimber Quality is Good}

The butt log of every sawtimber tree tallied in the Kansas inventory was log-graded. The total volume in sawtimber trees was grouped by butt log grade based on the sampled tree volumes by butt log grade. These volumes could not be converted to whole-tree log grades because the means to make this conversion accurately are not available. Volumes, then, represent the total volume in trees with the indicated butt log grade. However, experience in other States where butt log grade was converted to whole tree log grade indicates that the volume distribution by whole tree log grades is not much different from that of volumes in trees by butt log grade.

The volume of sawtimber is fairly evenly divided among the best three of the four log grades used to estimate saw log quality in Kansas (fig. 11). (See Log Grade section in Appendix for an explanation of individual log grades). Sycamore produces the highest proportion of sawtimber volume in grades 1 and 2 (log grade 1 is the highest quality) with 86 percent. Cottonwood ranks second in quality with 76 percent of its volume in these two grades, followed by ash (70 percent), willow (66 percent), black walnut (63 percent), and other hickories (63 percent). 


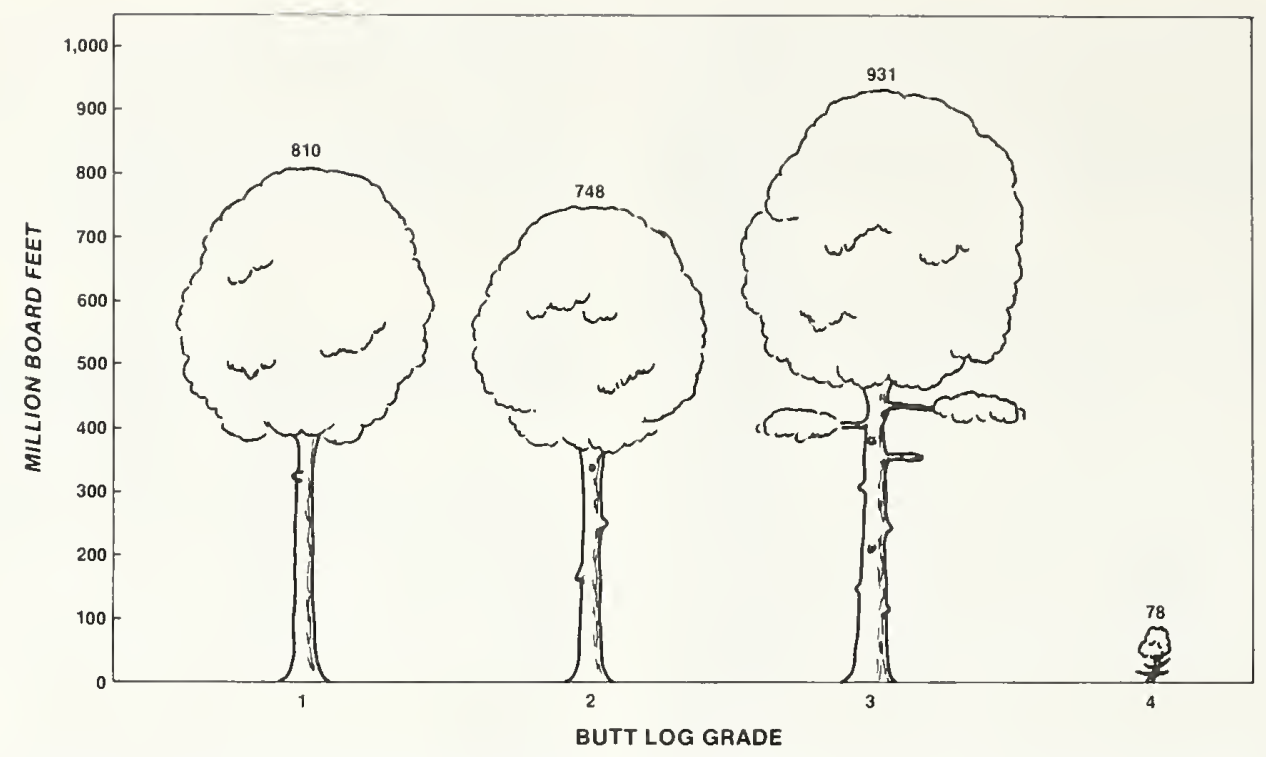

Figure 11.--Net volume of sawtimber on commercial forest land by butt log grade, Kansas, 1981.

\section{Black Walnut Volume Increasing}

Black walnut deserves special comment because of its exceptionally high value and the extraordinary demand for this fine hardwood. In addition to the 58 million cubic feet of black walnut growing stock in Kansas, there are 5 million cubic feet of short-log cull and 5 million cubic feet of rough and rotten cull black walnut on commercial forest land. Similarly there are 5 million cubic feet of walnut in all tree classes on wooded strips and another 3 million cubic feet of walnut on other nonforest land with trees (table 4).

Table 4.--Net volume of black walnut by land class and tree class, Kansas, 1981

(In million cubic feet)

\begin{tabular}{lccc}
\hline Tree class & $\begin{array}{c}\text { Commercial } \\
\text { forest }\end{array}$ & \multicolumn{2}{c}{ Nonforest with trees } \\
\cline { 3 - 4 } & 57.8 & 3.3 & 2.1 \\
Wrowing stock & 5.5 & 0.7 & 0.6 \\
$\begin{array}{l}\text { Short-log cull } \\
\text { Rough and rotten } \\
\quad \text { cull }\end{array}$ & 5.4 & 0.5 & 0.8 \\
\cline { 2 - 4 }$\quad$ All classes & 68.7 & 4.5 & 3.5 \\
\hline
\end{tabular}

Black walnut sawtimber volume on commercial forest land was 170 million board feet in 1981. The total walnut volume, including that from all tree classes and land classes, is 200 million board feet (see table 64 in Appendix).
The volume of black walnut increased between surveys faster than the hardwood volume average. Walnut growing stock increased 57 percent compared to an increase of 41 percent for all hardwood growing stock, and walnut sawitimber volume gained 57 percent compared to 31 percent for all hardwoods. However, volume of walnut in the larger diameter classes represents a smaller share of total walnut volume than it did in 1965 , reflecting the heavy demand for large trees. In 1965,15 percent of the walnut sawtimber volume was in trees 19 inches in diameter and larger, compared to 54 percent for all species. In 1981, only 12 percent of the walnut sawtimber volume was in trees at least 19 inches d.b.h., compared to 44 percent for all species.

\section{Nonforest Land has Large Volume}

In addition to the 711 million cubic feet of growing stock on commercial forest land discussed so far, nonforest land with trees contributes 115 million cubic feet in growing-stock trees, as seen below:

\section{Land use}

Wooded strips

Wooded pasture

Windbreaks

Total

\section{Volume of growing stock} (Million cubic feet)

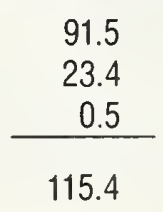

Of this nonforest land, wooded strips have the greatest potential for commercial timber production because they meet the definition of commercial forest land in every way except they are less than 120 feet wide. In addition to growing-stock volume shown 
above, wooded strips contain 300 million board feet in sawtimber trees.

Volume on wooded strips is fairly evenly divided between upland and lowland forest types. Cottonwood is the most abundant species on wooded strips (24 million cubic feet), followed by hackberry (13 million), bur oak (11 million), and ash (11 million). Forty-four percent of the growing-stock volume on wooded strips is in the Western Survey Unit, followed by the Northeastern Unit (33 percent), and the Southeastern Unit (23 percent).

In contrast to wooded strips, wooded pasture is primarily used for grazing; and a combination of this use, adverse sites, and poor tree quality preclude this land class from much commercial timber production. Wooded pastures are frequently rangeland or pastures invaded by low-quality trees. Some of these lands classed as wooded pasture may become commercial forest in the future as increased stocking and tree growth bring them into the required stocking to meet commercial forest standards. On the other hand, many others may be cleared of trees through proper range or pasture management.

\section{GROWTH, MORTALITY, REMOVALS, AND BIOMASS Net Growth Rises Slightly}

Net annual growth of growing stock on commercial forest land increased 5 percent between surveys, from 22 million cubic feet in 1964 to 23 million cubic feet in 1980 .

The Northeastern Unit accounted for 41 percent of the growth volume, but 44 percent of total growingstock volume. The Southeastern Unit, however, claimed 42 percent of the growth even though it had 35 percent of growing-stock volume. And the Western Unit, with its somewhat harsher growing conditions and somewhat larger diameter trees, contributed only 17 percent of the growth volume, although it accounted for 21 percent of the growing-stock inventory.

The average cubic foot growth rate in the State in 1980 was 3.3 percent of growing-stock inventory, compared to 4.4 percent in 1964 . This means that even though the volume of net growth increased between surveys ( 5 percent), it did not increase as fast as the growing-stock inventory (42 percent).

Net growth per acre increased from 18.5 cubic feet in 1964 to 19.2 cubic feet in 1980 , a 4 -percent gain.

The highest average cubic foot growth rate was in the Southeastern Unit (3.9 percent), followed by the Northeastern Unit (3.1 percent), and the Western Unit (2.6 percent).
Among species with the highest cubic foot growth rates are eastern redcedar (10.3 percent), boxelder ( 7.3 percent), hackberry (5.1 percent), and soft maple ( 4.5 percent).

Net annual growth of sawtimber in 1980 amounted to 64 million board feet--a growth rate of 2.5 percent of inventory. Sawtimber growth per acre averaged 53.0 board feet.

Net annual growth represents growth and ingrowth less natural mortality. The total volume lost by the death of a large, overmature tree cancels out the growth in many smaller diameter trees of the same species. Therefore, a species with a higher proportion of its trees and volume in the larger diameter classes, those likeliest to die, tends to have a lower net annual growth rate. Cottonwood, for example, has a net annual growing-stock growth rate of 1.9 percent, and a sawtimber growth rate of 1.4 percent--both rates well below average. Approximately half of the cottonwood cubic foot volume is in trees 21 inches in diameter and larger, compared to 19 percent for all other species combined.

\section{Potential Growth Higher than Current Growth}

The present net annual growth in Kansas is less than the potential net growth (or productive potential) of the commercial forest land, which cannot be measured accurately. However, we made a rough estimate of it by using site class information collected during the latest inventory. Site class values indicate the annual volume of growth per acre in fully stocked stands undisturbed by man (unmanaged or uncut) at culmination of mean annual increment ${ }^{5}$.

By multiplying the area of commercial forest land in each site by the midpoint of the growth range in that class, we estimated potential growth in the State (table 5). This method yields inflated results because most stands in Kansas are neither fully stocked nor undisturbed. In addition, it does not take into account the present distribution of age classes or the obvious differences in growth among them. Spurr and Vaux (1976) discounted an estimate of potential growth for the Nation by 10 percent to arrive at a figure they considered realistic. A study of the aspen type in Wisconsin suggests that potential growth is 52 percent higher than current growth (Lundgren and Hahn 1978).

${ }^{5}$ Culmination of mean annual increment is the point at which a curve plotting current annual increment crosses a curve plotting mean annual increment. 
Table 5.--Estimation of potential net annual growth on commercial forest land, Kansas, 1980

\begin{tabular}{lccc}
\hline $\begin{array}{c}\text { Site class - } \\
\text { cubic feet/acre/ } \\
\text { year }\end{array}$ & $\begin{array}{c}\text { Area of } \\
\text { commercial } \\
\text { forest land }\end{array}$ & $\begin{array}{c}\text { Potential net } \\
\text { growth/acre }\end{array}$ & $\begin{array}{c}\text { Total } \\
\text { potential } \\
\text { net growth }\end{array}$ \\
\hline & Thousand acres & Cu ft/acre/year & $\begin{array}{c}\text { Thousand cubic } \\
\text { feet/year }\end{array}$ \\
$120+$ & 2.1 & 142.0 & 298.2 \\
$85-119$ & 158.9 & 102.0 & $16,207.8$ \\
$50-84$ & 485.5 & 67.0 & $32,528.5$ \\
$20-49$ & 561.4 & 34.5 & $19,368.3$ \\
\hline Total & $1,207.9$ & -- & $68,402.8$ \\
\hline
\end{tabular}

${ }^{1}$ Midpoint of site class interval.

The undiscounted potential net annual growth for Kansas using the above method is 68.4 million cubic feet or 56.6 cubic feet per acre. If this potential growth is discounted 10 percent, the resulting 61.6 million cubic feet or 51.0 cubic feet per acre is a better estimate, although its accuracy can only be guessed.

This potential growth is not the ultimate growth possible--higher volumes of growth can be attained by applying intensive forest management practices such as thinning, fertilization, and planting or seeding genetically superior stock.

\section{Tree Disease Largest Known Cause of Death}

Net annual mortality of growing-stock trees increased from 3.3 million cubic feet in 1964 to 3.8 million in 1980, a 15 -percent gain. The mortality rate in 1964 was 0.7 percent of inventory; in 1980 it was 0.5 percent.

The largest volume of mortality was due to "unknown and other" causes, 43 percent of the total (fig. 12). This finding stems from the difficulty experienced by field crews in determining the primary cause of death in trees that had been dead for several years. Among the known causes of mortality, disease accounted for the largest volume, 40 percent of the total. Diseases of elm, principally Dutch elm disease, account for nearly six-tenths of the disease-caused mortality.

Mortality of sawtimber amounted to only 12.3 million board feet in 1980--0.5 percent of inventory.

\section{Timber Removals Higher Between Surveys}

Timber removals from growing stock increased from 8.3 to 14.0 million cubic feet between surveys, a 68 percent gain. Sawtimber removals jumped even higher, from 30.0 to 53.3 million board feet, a 77 -percent increase.

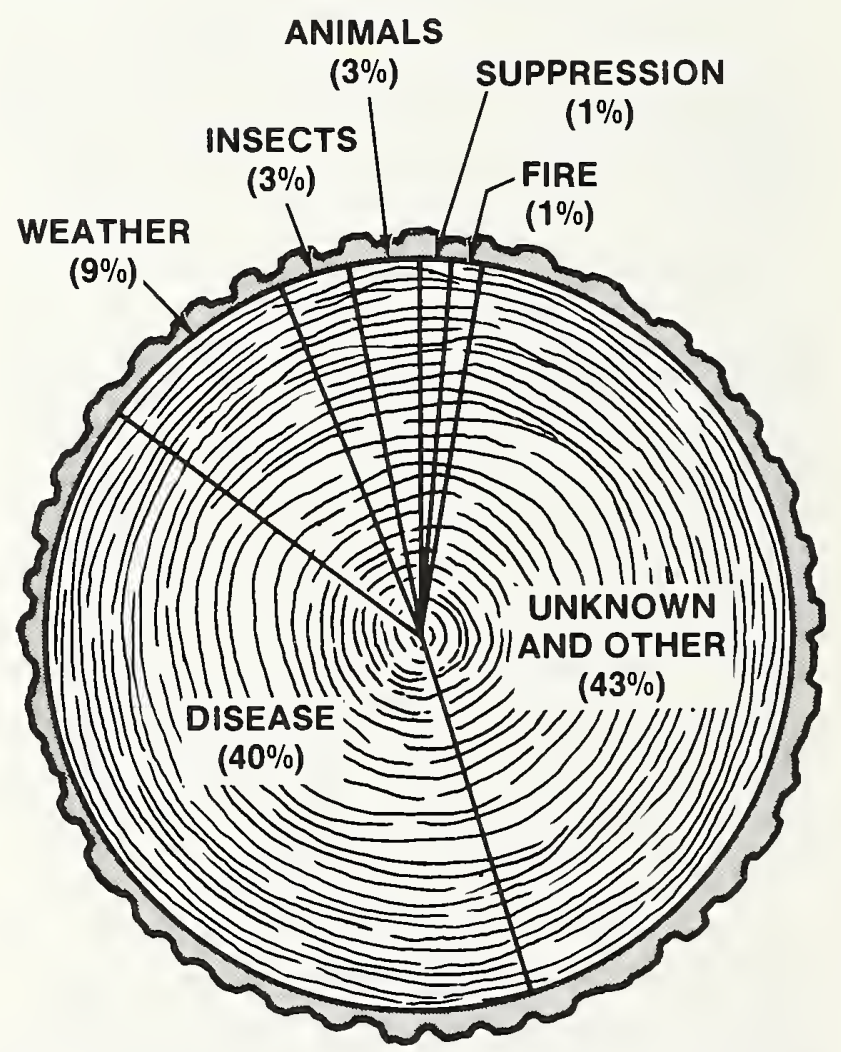

Figure 12.--Annual mortality of growing stock on commercial forest land by cause of mortality, Kansas, 1980. 
Cottonwood accounted for the largest volume of growing-stock removals in 1980 with 1.9 million cubic feet, compared to 1.1 million cubic feet in 1964, when it represented the second largest volume. In 1964 black walnut led all other species with 1.2 million cubic feet, but by 1980 it had dropped to third place among species, even though its removals volume had increased slightly to 1.3 million cubic feet. Removals of ash were the second largest in 1980 with 1.6 million cubic feet, nearly triple the 1964 removals volume of 0.6 million cubic feet.

The picture is somewhat different for sawtimber removals. Black walnut sawtimber removals in 1980 were 8.3 million board feet--a 14-percent increase from 1964--and second only to cottonwood at 9.2 million board feet. Ash was a distant third in sawtimber removals at 5.5 million board feet. This difference is due to a high proportion of the ash volume being utilized for fuelwood, which allows use of smaller diameter trees. By contrast, virtually all the walnut volume is utilized as saw logs and veneer logs.

The volume of removals increased between surveys for most species, but declined for a few species. Removals of hickory in 1980 were one half the $1964 \mathrm{vol}-$ ume even though the growing-stock inventory more than doubled during this period. The relative scarcity of large diameter hickories is a major factor--only 17 percent of the growing-stock volume of hickory is in trees 15 inches d.b.h. and larger. The removals volumes for soft maple and elm also declined 25 percent and 19 percent, respectively, between surveys. The elm decline came at the same time the inventory of elm growing stock fell to one-third of its 1964 volume.

Eighty-six percent of the growing-stock removals (12.1 million cubic feet) were harvested for roundwood products, primarily fuelwood and saw logs. Other removals--trees removed but not used for products, or trees left standing but "removed" from the commercial forest classification by land use change--amounted to 8 percent of the removals volume (1.1 million cubic feet). Logging residue--unused trees killed by logging or the unused portion of cut trees--accounted for the remaining 6 percent of the removals volume $(0.8$ million cubic feet).

Fuelwood ( 7.6 million cubic feet) accounted for 63 percent of the volume of roundwood products from growing stock in 1980 , and saw logs (4.3 million cubic feet) accounted for 36 percent. In 1964 the proportion was 35 percent for fuelwood and 45 percent for saw logs.

Ninety percent of the sawtimber removals volume (48.0 million board feet) was harvested for roundwood products. The proportion of sawtimber roundwood products in saw logs did not change much between 1964 (57 percent) and 1980 (55 percent). But the proportion of roundwood products used as fuelwood did shift from 1964 (20 percent) to 1980 (44 percent).

Although the Southeastern Unit contains only 35 percent of the State's growing-stock inventory, it accounted for 45 percent of the total removals volume. The Northeastern Unit accounted for 43 percent of the removals (44 percent of total inventory), and the Western Unit made up only 12 percent of the removals (21 percent of inventory).

Private land supplied virtually all of the removals from growing stock.

\section{Growing-stock Growth Two-thirds Higher Than Timber Removals}

One way of appraising the level of removals is to compare it with growth. This is an imperfect method because the volume of growth includes the growth from many trees too small to be part of the volume of removals.

In 1980 growing-stock removals ( 14.0 million cubic feet) amounted to only 60 percent of the volume of growth (23.2 million cubic feet). Sawtimber removals (53.3 million board feet) were 83 percent of growth (64.0 million board feet). These surpluses of growth over removals create the presently expanding inventory volumes.

\section{Aboveground Biomass Estimated}

Interest in whole-tree utilization is increasing as demand for wood fiber increases, as wood as an energy source is further exploited, and as costs of harvesting timber products continue to rise. An estimate of the aboveground weight of live trees and shrubs in Kansas was made as part of the inventory.

The total biomass of all live trees at least 1 inch d.b.h. on commercial forest land in the State amounts to 53.3 million green tons, an average of 44 tons per acre. The largest total biomass is in the oak-hickory forest type with 15.0 million green tons ( 47 tons per acre), but the greatest biomass density is in the cottonwood type where the 77 tons per acre converts to a total of 5.2 million tons. Among individual species, cottonwood contributes the largest share of biomass (6.8 million green tons), followed by hackberry (5.9 million tons), elm (4.2 million tons), bur oak (4.2 million tons), and ash (4.1 million tons).

The greatest proportion of live-tree biomass is located in growing-stock trees (64 percent). Cull trees 
provide 22 percent of the State's biomass, and trees 1 to 5 inches in diameter add the remaining 14 percent:

\section{Biomass component}

Weight

(Million green tons)

Growing-stock trees

Boles

Tops and limbs

Cull trees

Boles

Tops and limbs

1- to 5 -inch trees

Total

The biomass of shrubs is greatest in the willow forest type, where these plants average 2,786 pounds per acre green weight, and in the eastern redcedar-hardwood type where they average 2,767 pounds per acre. The upland elm-ash-locust and oak-hickory types produce the next largest shrub biomass amounts, 1,065 and 986 pounds per acre, respectively. Many shrubs are important wildlife food and cover species.

Among the tall shrubs (including live trees less than 1 inch in d.b.h.), roughleaf dogwood produces the greatest average biomass with 269 pounds per acre ${ }^{6}$. American elm was a distant second with 76 pounds per acre, followed by green ash with 74 pounds per acre, hackberry with 38 pounds per acre, and slippery elm with 30 pounds per acre.

${ }^{6} \mathrm{~A}$ weighted average based on the number of plots sampled for biomass in each forest type and the biomass of each species in the type, including types in which the shrub species was not found.
Buckbrush predominates among low shrubs with an average biomass of 129 pounds per acre. Poison ivy follows with 8 pounds per acre along with gooseberrycurrant with 7 pounds per acre.

Table 6 summarizes the per acre biomass yields for each forest type by vegetation component.

\section{PROJECTIONS Projections of National Timber Supply}

In the most recent projection of national demand for roundwood, annual consumption is estimated to increase from 13.3 billion cubic feet in 1976 to 25.2 billion in 2010, an 89-percent gain (USDA Forest Service 1981). Hardwood demand in the U.S. is projected to jump from 3.0 to 7.5 billion cubic feet during this period--a 150-percent increase. Demand for softwood is projected to be much higher but to increase at a slower rate, from 10.3 to 17.7 billion cubic feet--a 72 percent rise. The faster rate for hardwood demand reflects the expected increase in the use of hardwood roundwood for pulpwood and fuelwood, hardwood lumber for pallets and railroad ties, and hardwood plywood and veneer for furniture. This projection, made at a medium level of population and economic growth, assumes that the price trends in the base period used in making the projection (roughly from the late 1950's through the mid 1970's) continue through the projection period. ${ }^{7}$ When the excess of roundwood imports ( 4.5 billion cubic feet) over exports ( 1.5 billion) is subtracted from the projected demand in 2010 , the result

${ }^{7}$ Another projection was made under the assumption that prices will rise enough to maintain an equilibrium between projected demand and supply.

Table 6.--Biomass yields on commercial forest land by forest type and vegetation component, Kansas, 1981

(In pounds per acre green weight)

\begin{tabular}{lcccr}
\hline & \multicolumn{3}{c}{ Biomass yields } \\
\cline { 2 - 4 } Forest type & $\begin{array}{c}\text { All } \\
\text { Components }\end{array}$ & $\begin{array}{c}\text { Tall } \\
\text { shrubs }\end{array}$ & $\begin{array}{c}\text { Low } \\
\text { shrubs }\end{array}$ & $\begin{array}{c}\text { Live } \\
\text { trees }\end{array}$ \\
\hline & & & \\
Eastern redcedar-hardwood & 44,430 & 2,707 & 60 & 41,663 \\
Oak-hickory & 95,903 & 834 & 152 & 94,917 \\
Post-blackjack oak & 93,090 & 200 & 194 & 92,696 \\
Upland plains hardwoods & 85,179 & 493 & 177 & 84,509 \\
Elm-ash-cottonwood & 88,461 & 582 & 160 & 87,719 \\
Cottonwood & 153,688 & 474 & 126 & 153,088 \\
Willow & 62,400 & 2,649 & 137 & 59,614 \\
Lowland plains hardwoods & 97,600 & 722 & 183 & 96,695 \\
Upland elm-ash-locust & 47,411 & 892 & 173 & 46,346 \\
Nonstocked & 31,484 & 189 & 69 & 31,226 \\
\hline
\end{tabular}


is the annual demand on United States forests--22.2 billion cubic feet.

National roundwood supplies (timber available for harvest) are projected to increase from 12.1 to 18.7 billion cubic feet between 1976 and $2010 .{ }^{8}$ Projected demand on United States forests in 2010 exceeds supply by 3.5 billion cubic feet. The short-fall is much larger for softwoods (3.3 billion cubic feet) than for hardwoods ( 0.2 billion).

\section{Timber Projections for Kansas}

Kansas, with its comparatively small timber resource and the primacy of hardwoods, will play a minor role in meeting the Nation's future demand-supply problems, which chiefly concern softwoods. However, the State will continue to be an important supplier of black walnut nationally. To gain perspective on what lies ahead for Kansas, we made several projections of the State's timber resource under different levels of removals.

We made two 30-year projections using the Timber Resource Analysis System (TRAS) program (Alig et al. 1982), a computer program for updating, backdating and projecting timber resource information. The first projection assumes a continuation of recent levels of timber removals (low removals option), and the second assumes a higher level of removals (high removals option). Softwoods and hardwoods were grouped together because the volume of softwoods is so small. TRAS uses a stand projection technique involving input of number of trees, growth rates, mortality rates, and removal rates, all by 2 -inch diameter classes, along with assumed total removals by year and assumed ingrowth into the 2-inch diameter class.

Assumptions common to both options are: (1) the area of commercial forest land will remain unchanged (some decline is expected, but not enough to affect the results of the projection); (2) radial growth will decline in relation to the increase of basal area per acre of trees; (3) the intensity of forest management will continue at the rate indicated by recent trends; and (4) the volume of "other" removals will drop during the period as more of these trees are utilized for products.

\section{Low Removals Option Projection}

The low option assumes that timber removals will increase from 14.0 million cubic feet in 1980 to 25.8

${ }^{8}$ This projection shows the volume of timber available for harvest from domestic forests if recent trends in the forces determining supply, such as commercial forest area, management levels, and prices, continue through the projection period. million cubic feet in 2010. Growth is projected to exceed removals throughout the period, to peak about 1999, then to turn down. Growing-stock inventory, then, is projected to increase at an average annual rate of 1.81 percent or 13 million cubic feet (fig. 13). The assumed average annual change in removals used in the projections is shown in the following tabulation:

\section{Period}

1981-1985

1986-1990

1991-1995

1996-2000

2001-2005

2006-2010

\section{Low removals} option
Removals in this option increase throughout the period, ending in 201084 percent higher than in 1980. Removals for saw logs and fuelwood, the major roundwood products in 1980, are both expected to rise during the projection period, but more of these products will probably be recovered from "other" removals.

Growth is projected to increase from 23.2 million cubic feet in 1980 to 35.2 million cubic feet in 1999, then to turn down to 31.4 million cubic feet in 2010 .
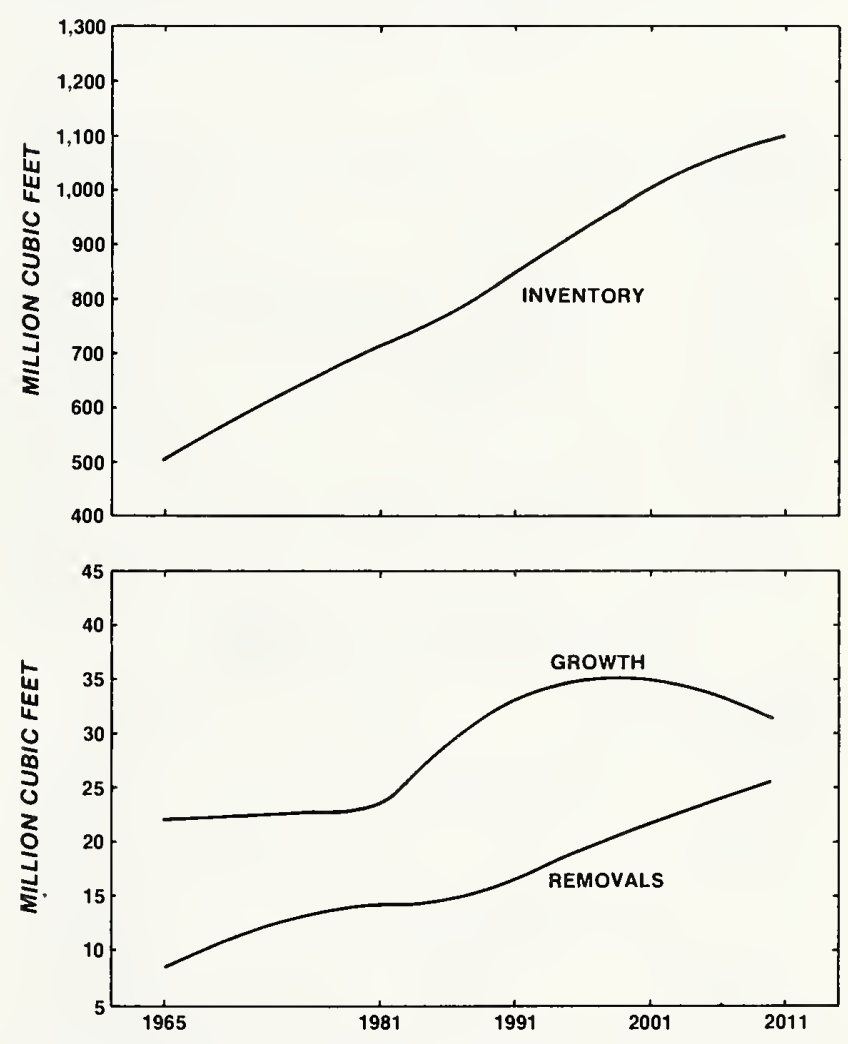

Figure 13.--Removals, net growth, and inventory of growing stock in Kansas, 1965 and 1981, and low removals option projection for 1982-2011. 
The surplus of growth over removals was 9.2 million cubic feet in 1980. This surplus is projected to grow to 16.4 million cubic feet in 1992, tapering off to 5.6 million cubic feet in 2010 .

Growing-stock inventory is projected to climb during the entire period, but to increase at a slower rate during the last decade. The 1981 inventory of 711.3 million cubic feet is projected to reach $1,098.2$ million cubic feet by 2011--a 54-percent gain.

\section{High Removals Option Projection}

Removals under this option reflect a higher level of harvesting than the previous option. Timber removals are projected to exceed growth by 2008 , and inventory is projected to turn down at that time (fig. 14).

Timber removals jump from 14.0 million cubic feet in 1980 to 37.2 million cubic feet in 2010, a 166-percent gain. Markets for forest products are larger than assumed for the low option.

Net growth is projected to climb from 23.2 million cubic feet in 1980, peak at 35.5 million cubic feet in 2000 , then fall off to 34.4 million in 2010 . The excess of growth over removals in 1980, 9.2 million cubic feet, is projected to swell to 13.4 million cubic feet in 1990 , then to vanish in 2008 when the growth and removals
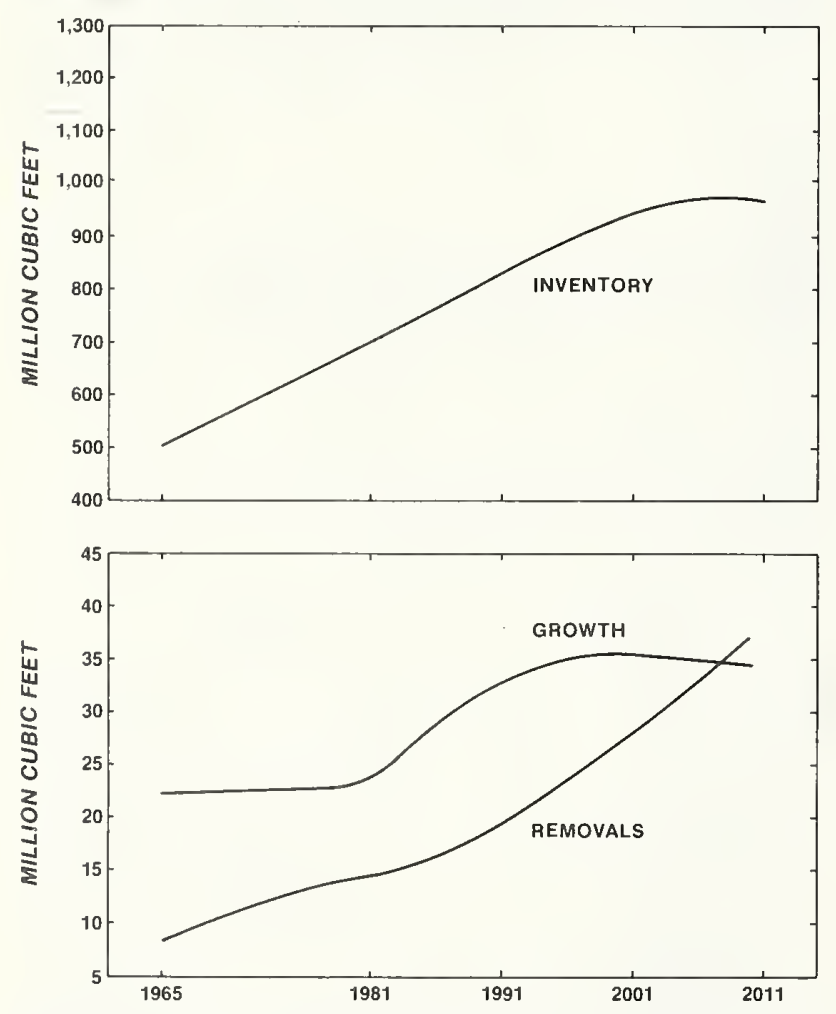

Figure 14.--Removals, net growth, and inventory of growing stock in Kansas, 1965 and 1981, and high removals option projection for 1982-2011. curves intersect. By 2010 the deficit of removals over growth is projected to be 2.8 million cubic feet.

Inventory rises more slowly than for the low option, from 711.3 million cubic feet in 1981 to a peak of 974.0 million cubic feet in 2008. Responding to the deficit of removals over growth beyond 2008, inventory then sags to 969.3 million cubic feet by 2011 .

\section{The Outlook}

These projections probably represent the bounds within which the actual forest situation will develop. The low and high removals options are valid only to the extent that the assumptions upon which they are based are realized. Projections for the first decade are the most significant because rapidly changing economic, market, and social conditions may invalidate these assumptions and sharply reduce the value of projections for the last two decades.

The projections are not intended to convey desirable goals from silvicultural, social, or economic perspectives. They simply indicate what is likely to happen if forests in the State are managed much as they have been for the past 16 years and if harvesting occurs at a "high" or a "low" level.

Inventory is likely to continue accumulating at a rate close to that of current times, for about two decades, then slow down or decline during the third decade. If timber management efforts are increased beyond that of recent trends, higher growth and largerthan-projected inventories could develop toward the end of the projection period. More complete utilization of residues, tree tops and limbs, the volumes of which are not included in growing-stock inventories, is desirable and would further extend supplies of wood. The rekindled interest in fuelwood as a source of energy suggests that this may be happening. Inventories could be smaller than projected if the area of commercial forest land declines faster than assumed.

The area of the oak-hickory forest type, which surged by 71 percent from its 1965 area to become the largest type in 1981, will probably continue to gain at the expense of the upland plains hardwoods and upland elm-ash-locust types. The rate of increase, however, may slow.

Total output of fuelwood from roundwood nearly quadrupled from 1964 to 1980 --from 68,000 cords to 255,000 cords. There is little reason to expect this upward trend to do anything but continue. This increased utilization for fuelwood presents both an opportunity and a threat to improved forest management. If the lower quality trees are taken for fuelwood, a market incentive will be provided to accomplish timber stand improvement to release desirable growing- 
stock trees. If, on the other hand, many of the best young growing-stock trees are taken out for fuelwood, the future potential to produce quality saw logs will be greatly reduced. The key is proper landowner understanding and application of sound forest management practices.

Because nonindustrial forest landowners possess 96 percent of the commercial forest area and 94 percent of the growing-stock volume, they obviously control the destiny of the State's forest resource. Improvement in the forest situation will be slow unless many of these independent owners become convinced that timber management is economically attractive. Policies that seek to bring practical technical information and field assistance on timber sale preparation and administration along with forest management will help to bring about more positive change among forest landowners. These owners might also be persuaded by policies that make timber-growing more profitable to them, such as efforts to expand markets for timber products and to increase financial incentives for performing needed management work.

\section{LITERATURE CITED}

Alig, Ralph J.; Brink, Glen E.; Goforth, Marcus H.; La Bau, Vernon J.; Mills, Thomas J. TRAS 1980-User's manual for an expanded version of the TRAS projection system. Ft. Collins, Co: U.S. Department of Agriculture, Forest Service, Rocky Mountain Forest and Range Experiment Station; 1982. 63 p.

Chase, Clarence D.; Strickler, John K. Kansas woodlands. Resour. Bull. NC-4, St. Paul, MN: U.S. Department of Agriculture, Forest Service, North Central Forest Experiment Station; 1968. 50 p.

Fernald, Merritt L. Gray's manual of botany. New York: American Book Company; 1950. 1,632 p.

Little, Elbert L., Jr. Checklist of United States trees (native and naturalized). Agric. Handb. 541. Washington, DC: U.S. Department of Agriculture; 1979. $375 \mathrm{p}$.

Lundgren, Allen L.; Hahn, Jerold T. The extent and characteristics of low productivity aspen areas in Wisconsin. Gen. Tech. Rep. NC-45. St. Paul, MN: U.S. Department of Agriculture, Forest Service, North Central Forest Experiment Station; 1978. 24 p.

Spurr, Stephen H.; Vaux, Henry J. Timber: biological and economic potential. Science 191(4228): 752-756; 1976.

U.S. Department of Agriculture, Forest Service. An assessment of the forest and range land situation in the United States. For. Resour. Rep. 22. Washington, DC: U.S. Department of Agriculture, Forest Service; 1981. 352 p.

Vaughn, C. L.; Wollin, A.C; McDonald, K. A.; Bulgrin, E. H. Hardwood log grades for standard lumber. Res.
Pap. FPL-63. Madison, WI: U.S. Department of Agriculture, Forest Service, Forest Products Laboratory; $1966.52 \mathrm{p}$.

\section{APPENDIX Accuracy of Survey}

Forest Inventory and Analysis information is based on a sampling procedure designed to provide reliable statistics at the State and Survey Unit levels. Consequently, the reported figures are estimates only. However, a measure of reliability of these figures is given by sampling errors. These sampling errors mean that the chances are two out of three that if a 100percent inventory had been taken, using the same methods, the results would have been within the limits indicated.

For example, the estimated area of commercial forest land in Kansas in 1981, 1,207.9 thousand acres, has a sampling error of \pm 2.45 percent $( \pm 29,594$ acres $)$. The commercial forest area from a 100-percent inventory, then, would be expected to fall between 1,237.5 and $1,178.3$ thousand acres $(1,207.9 \pm 29.6)$, there being a one in three chance that this is not the case.

The following tabulations show sampling errors for State and Survey Unit totals of information collected during the 1981 Kansas Forest Inventory.

\section{STATE TOTALS}

Item

Growing stock:

Volume

Growth

(Million cubic feet)

711.3

23.2

14.0

Sampling error

Removals

Sawtimber:

Volume

Growth

Removals

(Million board feet)

$2,566.2$

64.0

53.3

(Percent)

3.52

5.61

17.00

4.24

6.44

20.10

(Thousand acres)

Commercial forest

area

$1,207.9$

2.45

\section{NORTHEASTERN UNIT}

Item

Growing stock:

Volume

Growth

Removals

Sawtimber:

Volume

Growth

Removals
(Million cubic feet)

315.1

9.7

6.0

(Million board feet)

$1,107.6$

27.5

23.1

(Thousand acres)

Commercial forest area
588.1
Sampling error

(Percent)

4.82

8.05

26.37

5.89

9.22

32.15

3.16 


\section{SOUTHEASTERN UNIT}

$\begin{array}{lcc}\begin{array}{c}\text { Item } \\ \text { Growing stock: }\end{array} & \begin{array}{c}\text { Sampling error } \\ \text { (Million cubic feet) }\end{array} \\ \text { Volume } & 249.1 & 5.28 \\ \text { Growth } & 9.7 & 8.70 \\ \text { Removals } & 6.3 & 27.89 \\ \text { Sawtimber: } & \text { (Million board feet) } & \\ \text { Volume } & 828.5 & 6.39 \\ \text { Growth } & 27.6 & 9.86 \\ \text { Removals } & 24.6 & 31.82 \\ \text { Commercial forest } & \text { (Thousand acres) } \\ \text { area } & & \\ & 437.0 & 3.89\end{array}$

\section{WESTERN UNIT}

$\begin{array}{lcc}\begin{array}{c}\text { Item } \\ \text { Growing stock: }\end{array} & \begin{array}{c}\text { Sampling error } \\ \text { (Percent) }\end{array} \\ \text { Volume } & 147.1 & 13.27 \\ \text { Growth } & 3.9 & 20.30 \\ \text { Removals } & 1.7 & 48.20 \\ \text { Sawtimber: } & \text { (Million board feet) } & \\ \text { Volume } & 630.1 & 14.18 \\ \text { Growth } & 8.9 & 17.76 \\ \text { Removals } & 5.6 & 46.36 \\ \text { Commercial forest } & \text { (Thousand acres) } \\ \text { area } & & \\ & & \\ & & \end{array}$

As survey data are broken down into sections smaller than State or Survey Unit totals, the sampling error increases. The smaller the breakdown, the larger the sampling error. For example, the sampling error for area of commercial forest land in a particular county is higher than that for total commercial forest area in the Survey Unit (tables 110-113 show the sampling errors for estimates smaller than State and Survey Unit totals).

\section{SURVEY PROCEDURE}

The major steps in the survey of Kansas were as follows:

1. A total of 275,271 1-acre points were systematically distributed across aerial photos of the entire State. Photo interpretors classified these points as forest land $(9,570)$, nonforest land with trees $(5,208)$, nonforest land without trees $(258,420)$, questionable $(424)$, and water $(1,649)$, in order to make a preliminary estimate of forest area. Next, all of the forest points $(9,570), 543$ of the nonforest with tree points, and all of the questionable points (424) were stereoclassified as to forest type, stand-size class, and density. Then 1,386 points classed as forest, 96 points classed as questionable, and 543 points classed as nonforest with trees were examined on the ground to correct the preliminary area estimate for errors in classification and for actual changes in land use since the photos were taken. At each of the 937 commercial forest locations, variable-radius plots (basal area factor 37.5) were established at 10 points uniformly placed over the sample acre. Of these 937 locations, 222 were plots established during the 1965 survey and remeasured during the 1981 survey to provide improved growth and mortality information. Tree measurements made at commercial forest locations were the basis for estimates of timber volume, growth, mortality, number of trees, and other forest classifications.

2. An estimate of the volume of black walnut on nonforest land was made by establishing 10 -point, variable-radius plots on nonforest ground-check locations wherever black walnut trees were found. This included black walnut trees found on fence rows or as scattered trees, but did not include walnut trees in urban areas, lawns, or in other areas where harvest of these trees is unlikely.

3. An estimate of the volume of timber on nonforest wooded strips was made by establishing 10-point, fixed-radius plots on wooded strip ground-check locations. The design and size of these plots were adjusted to allow for the narrowness of the strips.

4. Growth and mortality on commercial forest land were estimated using data collected on both remeasurement plots (those established in 1965 and remeasured in 1981) and new plots established in 1981. Growth was measured on remeasurement plots as the observed change in volume on surviving trees. Growth was estimated on new plots by using growth equations developed during the 1972 Missouri survey. Mortality on remeasurement plots was calculated as the observed volume in trees that died between surveys. On new plots, mortality was estimated by determining the volume in trees that died within 3 years of plot establishment. Growth and mortality were converted to an annual basis.

5. Statistics on timber utilization during 1980 were obtained from mill surveys. State and Extension Forestry, Kansas State University (S\&EF) canvassed resident sawmills and other primary wood-using plants. The North Central Forest Experiment Station canvassed out-of-State primary wood-using mills such as sawmills and veneer mills to determine their use of timber from Kansas. State and Extension Forestry made estimates of 1980 fuelwood and post production from roundwood based on the best information available on recent output of these products. Estimates of primary mill residue used for fuelwood were obtained from the canvass of Kansas primary wood-using 
plants. Timber cut for products by ownership class was determined by a canvass of public and industrial timber owners. The portion of timber harvest unaccounted for by the latter owners was grouped under "farmer and other owners".

6. Wood utilization factors for converting timber products output to timber removals for saw logs, veneer logs, and cooperage logs were obtained during the 1971-1972 Missouri utilization study. Factors for fuelwood were obtained during the 1964 Kansas utilization study. Factors for all other products were obtained during the 1959-1960 Missouri utilization study.

7. Field data were sent to St. Paul for processing and analysis.

\section{Comparing Kansas' Third Survey with the Second Survey}

Data from new forest surveys are often compared with data from earlier ones to determine trends in forest areas and volumes. Changes in procedures and definitions between surveys make it necessary to adjust earlier survey data to make them comparable with data from the new survey.

We adjusted the published 1965 area of commercial forest land, 1,192.4 thousand acres, by subtracting 900 acres that were classed commercial forest in 1965 , but were Christmas tree production areas (productive-reserved forest land) in 1981. The adjusted 1965 area (1,191.5 thousand acres) can be compared directly with the 1981 area $(1,207.9$ thousand acres).

A test was made to ensure that we could move from the adjusted 1965 volumes to the new 1981 volumes by means of Timber Resource Analysis System (TRAS), a Forest Service computer program for updating, backdating, and projecting timber volume, growth, mortality, and removals. TRAS recalculated 1965 volumes using 1981 estimates of cubic foot volume per tree and 1981 board foot-cubic foot ratios. The volumes had to be adjusted so that differences between surveys represented actual change and not merely change in the volume equations used.

\section{LOG GRADE}

The butt log of every sawtimber tree on every full permanent sample plot, remeasurement plot, and nonforest plot with black walnut trees $(4,194$ trees) was graded for quality. Logs were graded on the basis of external characteristics. Hardwood species were graded according to "Hardwood Log Grades for Standard Lumber" (Vaughn et al. 1966). The best 12 -foot section of the lowest 16 -foot hardwood log, or the best 12 -foot upper section if the butt log did not meet minimum log-grade standards, was graded as follows: 
Forest Service standard grades for hardwood factory saw logs

\begin{tabular}{|c|c|c|c|c|c|c|c|c|c|}
\hline \multirow{2}{*}{\multicolumn{2}{|c|}{ Grading factors }} & \multicolumn{8}{|c|}{ Specifications } \\
\hline & & \multicolumn{3}{|c|}{ Log grade 1} & \multicolumn{4}{|c|}{ Log grade 2} & \multirow{2}{*}{$\begin{array}{c}\text { Log grade } 3 \\
\text { Butts and } \\
\text { uppers }\end{array}$} \\
\hline \multicolumn{2}{|l|}{ Position in tree } & $\begin{array}{c}\text { Butts } \\
\text { only }\end{array}$ & \multicolumn{2}{|c|}{$\begin{array}{l}\text { Butts and } \\
\text { uppers }\end{array}$} & \multicolumn{4}{|c|}{ Butts and uppers } & \\
\hline \multicolumn{2}{|c|}{ Scaling diameter, inches } & $13-15^{1}$ & $16-19$ & $20+$ & $11+2$ & & $12+$ & & $8+$ \\
\hline \multicolumn{2}{|c|}{ Length without trim, feet } & & $10+$ & & $10+$ & $8-9$ & $10-11$ & $12+$ & $8+$ \\
\hline \multirow{3}{*}{$\begin{array}{l}\text { Required clear } \\
\text { cuttings }^{3} \text { of each of } \\
\text { three best faces }\end{array}$} & Min. length, feet & 7 & 5 & 3 & 3 & 3 & 3 & 3 & 2 \\
\hline & Max. number & 2 & 2 & 2 & 2 & 2 & 2 & 3 & $\begin{array}{l}\text { No } \\
\text { Limit }\end{array}$ \\
\hline & $\begin{array}{l}\text { Min. proportion of } \\
\text { log length } \\
\text { required in } \\
\text { clear cutting }\end{array}$ & $5 / 6$ & $5 / 6$ & $5 / 6$ & $2 / 3$ & $3 / 4$ & $2 / 3$ & $2 / 3$ & $1 / 2$ \\
\hline \multirow{2}{*}{$\begin{array}{l}\text { Maximum } \\
\text { sweep and crook } \\
\text { allowance }\end{array}$} & $\begin{array}{l}\text { For logs with less } \\
\text { than one-fourth } \\
\text { of end in sound } \\
\text { defects }\end{array}$ & \multicolumn{3}{|c|}{15 percent } & \multicolumn{4}{|c|}{30 percent } & 50 percent \\
\hline & $\begin{array}{l}\text { For logs with more } \\
\text { than one-fourth } \\
\text { of end in sound } \\
\text { defects }\end{array}$ & \multicolumn{3}{|c|}{10 percent } & \multicolumn{4}{|c|}{20 percent } & 35 percent \\
\hline \multicolumn{2}{|c|}{ Maximum scaling deduction } & \multicolumn{3}{|c|}{40 percent $^{5}$} & \multicolumn{4}{|c|}{50 percent $^{6}$} & 50 percent \\
\hline
\end{tabular}

'Ash and basswood butts can be 12 inches if they otherwise meet requirements for small \#1's.

'Ten-inch logs of all species can be \#2 if they otherwise meet requirements for small \#1's.

${ }^{3}$ A clear cutting is a portion of a face, extending the width of the face, that is free of defects.

${ }^{4} A$ face is one-fourth of the surface of the log as divided lengthwise.

${ }^{5}$ Otherwise \#1 logs with 41-60 percent deductions can be \#2.

${ }^{6}$ Otherwise \#2 logs with 51-60 percent deductions can be \#3. 


\section{Forest Service standard specifications for hardwood construction logs (tie and timber logs) ${ }^{1}$}

\begin{tabular}{|c|c|c|}
\hline \multicolumn{2}{|c|}{ Position in tree } & Butt and upper \\
\hline \multicolumn{2}{|c|}{ Min. diameter, small end } & 8 inches + \\
\hline \multicolumn{2}{|c|}{ Min. length, without trim } & 8 feet \\
\hline \multicolumn{2}{|c|}{ Clear cuttings } & No requirements. \\
\hline \multicolumn{2}{|c|}{ Sweep allowance, absolute } & One-fourth of the diameter at the small end for each 8 feet of length. \\
\hline \multirow{3}{*}{$\begin{array}{l}\text { Sound } \\
\text { surface } \\
\text { defects }\end{array}$} & Single knots & $\begin{array}{l}\text { Any number, if no one knot has an average diameter above the callus in } \\
\text { excess of one-third of log diameter at point of occurrence. }\end{array}$ \\
\hline & Whorled knots & $\begin{array}{l}\text { Any number if sum of knot diameters above the callus does not exceed one- } \\
\text { third of log diameters at point of occurrence. }\end{array}$ \\
\hline & Holes & $\begin{array}{l}\text { Any number provided none has a diameter over one-third of log diameter at } \\
\text { point of occurrence, and none extends over } 3 \text { inches into included timber. }{ }^{2}\end{array}$ \\
\hline \multicolumn{2}{|c|}{ Unsound surface defects } & $\begin{array}{l}\text { Same requirements as for sound defects if they extend into included } \\
\text { timber. }{ }^{2} \text { No limit if they do not. }\end{array}$ \\
\hline \multirow[b]{2}{*}{$\begin{array}{l}\text { End } \\
\text { defects }\end{array}$} & Sound & No requirements. \\
\hline & Unsound & $\begin{array}{l}\text { None allowed; log must be sound internally, but will admit one shake } \\
\text { not to exceed one-fourth of the scaling diameter and will admit a lon- } \\
\text { gitudinal split not extending over } 5 \text { inches into the contained timber. }\end{array}$ \\
\hline
\end{tabular}

'These specifications are minimum for the class. If, from a group of logs, factory logs are selected first, thus leaving only nonfactory logs from which to select construction logs, then the quality range of the construction logs so selected is limited, and the class may be considered a grade. If selection for construction logs is given first priority, then it may be necessary to subdivide the class into grades.

${ }^{2}$ Included timber is always square, and dimension is judged from small end.

Softwood species were graded according to the following specifications: 
LOG GRADES FOR SOFTWOOD LOGS

\section{Grade 1}

1. Logs must be 16 inches or larger, 10 feet or longer, and with deduction for defect not over 30 percent of gross scale.

2. Logs must be at least 75 percent clear on each of three faces.

3. All knots outside clear cutting must be sound and not over $2^{1 / 2}$ inches in diameter.

\section{Grade 2}

1. Logs must be 12 inches or larger, 10 feet or longer, and with a net scale after deduction for defect of at least 50 percent of the gross contents of the log.

2. Logs must be at least 50 percent clear on each of three faces or 75 percent clear on two faces.

\section{Grade 3}

1. Logs must be 6 inches or larger, 8 feet or longer, and with a net scale after deduction for defect of at least 50 percent of the gross contents of the log.

Note: A) Diameters are diameter inside bark at small end of log.

B) Percent clear refers to percent clear in one continuous section.

\section{PRINCIPAL TREE AND SHRUB SPECIES GROUPS IN KANSAS 9}

\section{Tree Species}

\section{SOFTWOODS}

Eastern redcedar. Juniperus virginiana HARDWOODS

Bur oak. Quercus macrocarpa

Select white oaks

White oak Quercus alba

Chinkapin oak Quercus muehlenbergii

Other white oaks

Post oak Quercus stellata

Select red oaks

Northern red oak Quercus rubra Shumard oak ....................... Quercus shumardii Other red oaks

Black oak. Quercus velutina

Blackjack oak Quercus marilandica

Pin oak Quercus palustris

Shingle oak Quercus imbricaria Select hickory

Shellbark hickory Carya laciniosa

Mockernut hickory Carya tomentosa

${ }^{9}$ The common and scientific names of tree species are based on: Little, Elbert L., Jr. 1979. The common and scientific names of shrubs are based on: Fernald, Merritt L. 1950 .
Shagbark hickory Carya ovata

Other hickory

Bitternut hickory.

Carya cordiformis

Black hickory Carya texana

Pecan Carya illinoensis

Hard maple

Sugar maple Acer saccharum

Soft maple

Silver maple Acer saccharinum

Ash

Green ash White ash Cottonwood

Eastern cottonwood

Basswood

American basswood

Tilia americana Elm

American elm

Ulmus americana

Siberian elm Ulmus pumila

Slippery elm Ulmus rubra

Black walnut. Juglans nigra

Willow

Black willow Salix nigra

Boxelder. Acer negundo

Hackberry Celtis occidentalis

Sycamore Platanus occidentalis

Other hardwoods

Black cherry Prunus serotina

Black locust Robinia pseudoacacia

Honeylocust Gleditsia triacanthos

Kentucky coffeetree ........... Gymnocladus dioicus

Northern catalpa Catalpa speciosa

Common persimmon

Red mulberry Diospyros virginiana

River birch Morus rubra

Sugarberry Betula nigra

Noncommercial species

Texas buckeye. Aesculus glabra var. arguta Ailanthus Ailanthus altissima Eastern redbud ........................ Cercis canadensis Hawthorn. Crataegus spp.

Osage-orange Maclura pomifera

Eastern hophornbeam ............. Ostrya virginiana

\section{SHRUB SPECIES}

\section{TALL SHRUBS}

Roughleaf dogwood

Chokecherry

Cornus drummondii

Wild plum Prunus virginiana

Pawpaw Prunus spp.

Beaked hazel Asimina triloba

Prickly ash Corylus cornuta

Viburnum

Elder.

Sumac

Buttonbush Viburnum spp. Sambucus spp. Sambucus spp. Xanthoxylum americanum Cephalanthus occidentalis 
Wahoo

Euonymus atropurpureus

Willow Salix spp.

Sassafras Sassafras albidum

\section{LOW SHRUBS}

Virginia creeper Parthenocissus spp.

Gooseberry-currant Ribes spp.

Raspberry-blueberry Rubus spp.

Rose. Rosa spp.

American bladdernut Staphylea trifolia Bilberry-blackberry Vaccinium spp. Honeysuckle Lonicera spp. Buckbrush Poison ivy Pipe-vine. Moonseed Rpp. Rhus radicans Greenbrier Grape Smilax spp. Vitis spp.

\section{METRIC EQUIVALENTS OF UNITS USED IN THIS REPORT}

1 acre $=4,046.86$ square meters or 0.405 hectare .

1,000 acres $=405$ hectares.

Breast height $=1.4$ meters above the ground.

1 cubic foot $=0.0283$ cubic meter.

1 foot $=30.48$ centimeters or 0.3048 meter.

1 inch $=25.4$ millimeters, 2.54 centimeters, or 0.0254 meter.

1 pound $=0.454$ kilogram.

1 ton $=0.907$ metric ton.

\section{DEFINITION OF TERMS}

Acceptable trees.--Growing-stock trees of commercial species that meet specified standards of size and quality, but do not qualify as desirable trees.

Area-condition classes.--Class 10.--Areas fully stocked with desirable trees but not overstocked.

Class 20.--Areas fully stocked with desirable trees, but overstocked with all live trees.

Class 30.--Areas medium to fully stocked with desirable trees, and with less than 30 percent of the area controlled by other trees and/or inhibiting vegetation or surface conditions that will prevent occupancy by desirable trees.

Class 40.--Areas medium to fully stocked with desirable trees and with 30 percent or more of the area controlled by other trees and/or conditions that ordinarily prevent occupancy by desirable trees.

Class 50.--Areas poorly stocked with desirable trees, but fully stocked with growing-stock trees.

Class 60.--Areas poorly stocked with desirable trees, but with medium to full stocking of growingstock trees.

Class 70.--Areas poorly stocked with desirable trees, and poorly stocked with growing-stock trees. Basal area.--The area in square feet of the cross section at breast height of a single tree. When the basal areas of all trees in a stand are summed, the result is usually expressed as square feet of basal area per acre.

Biomass.--The aboveground volume of all live trees (including bark and foliage). Biomass is made up of 5 components:

Growing-stock bole.--Biomass of a growing-stock tree from a 1-foot stump to a 4-inch top.

Growing-stock tops and limbs.--Biomass of a growing-stock tree from a 1-foot stump minus the growing-stock bole.

Cull bole.--Biomass of a cull tree from a 1-foot stump to a variable 4 -inch top.

Cull tops and limbs.--Biomass of a cull tree from a 1 -inch stump minus the cull bole.

1 - to 5 -inch trees.--Biomass of all live trees 1 to 5 inches in diameter at breast height.

Commercial forest land.--Forest land producing or capable of producing crops of industrial wood and not withdrawn from timber utilization (Note: Areas qualifying as commercial forest land can produce more than 20 cubic feet per acre per year of annual growth under management. Currently inaccessible and inoperable areas are included, except when the areas involved are small and unlikely to become suitable for production of industrial wood in the foreseeable future.) Also see definition of pastured commercial forest land.

Commercial species.--Tree species presently or prospectively suitable for industrial wood products. (Note: Excludes species of typically small size, poor form, or inferior quality such as hophornbeam and hawthorn.)

County and municipal land.--Land owned by counties and local public agencies or municipalities, or land leased to these governmental units for 50 years or more.

Cropland.--Land under cultivation within the past 24 months, including cropland harvested, crop failures, cultivated summer fallow, idle cropland used only for pasture, orchards, and land in soil improvement crops, but excluding land cultivated in developing improved pasture.

Cu11.--Portions of a tree that are unusable for industrial wood products, because of rot, form, or other defect.

Desirable trees.--Growing-stock trees having no serious defects in quality limiting present or prospective use, and of relatively high vigor, and containing no pathogens that may result in death or serious deterioration before rotation age. These are trees that would be favored by forest managers in silvicultural operations.

Diameter classes.--A classification of trees based on diameter outside bark, measured at breast height ( $4 \frac{1}{2} 2$ feet above the ground). (Note: d.b.h. is the com- 
mon abbreviation for diameter at breast height. Two-inch diameter classes are commonly used in Forest Survey, with the even inch the approximate midpoint for a class. For example, the 6 -inch class includes trees 5.0 through 6.9 inches d.b.h. inclusive.)

Farm.--Any place from which $\$ 1,000$ or more of agricultural products were produced and sold during the year.

Farmer-owned land.--Land owned by operators of farms. (Note: Excludes land leased by farm operators from nonfarm owners, such as railroad companies and States.)

Forest land.--Land at least 16.7 percent stocked by forest trees of any size, or formerly having had such tree cover, and not currently developed for nonforest use. (Note: Stocking is measured by comparison of basal area and/or number of trees, by age or size and spacing with specified standards.) The minimum area for classification of forest land is 1 acre. Roadside, streamside, and shelterbelt strips of timber must have a crown width at least 120 feet to qualify as forest land. Unimproved roads and trails, streams, or other bodies of water or clearings in forest areas shall be classed as forest if less than 120 feet wide. Also see definitions of land area, commercial forest land, noncommercial forest land, productive-reserved forest land, stocking, unproductive forest land, nonforest land, and water.

Forest industry land.--Land owned by companies or individuals operating primary wood-using plants.

Forest trees.--Woody plants having a well-developed stem and usually more than 12 feet in height at maturity.

Forest types.--A classification of forest land based upon the species forming a plurality of live tree stocking. Major forest types in Kansas are:

Eastern redcedar-hardwood.--Forests in which hardwoods comprise a plurality of the stocking but in which eastern redcedar comprises 25 percent or more of the stocking. Found on dry uplands, usually abandoned pastures or fields.

Oak-hickory.--Forests in which upland oaks (white, northern red, black) or hickory, singly or in combination, comprise a plurality of the stocking, except for stands classed as eastern redcedar-hardwood or as post-blackjack oak. Occurs on a variety of soils.

Post-blackjack oak.--Forests in which post oak or blackjack oak, singly or in combination, comprise a majority of the stocking. Occurs on dry uplands and ridges.

Upland plains hardwoods.--Forests in which black walnut, hackberry, and bur oak, singly or in combination, comprise a plurality of the stocking. Commonly found on slopes and uplands.
Elm-ash-cottonwood.--Lowland forest in which elm, ash, cottonwood, and willow, singly or in combination, comprise a plurality of the stocking, except for those in which cottonwood or willow comprise a majority of the stocking. Found on first or second bottoms of major streams.

Cottonwood.--Forests in which cottonwood comprises a majority of the stocking.

Willow.--Forests in which willow comprises a majority of the stocking.

Lowland plains hardwoods...Forests in which black walnut, hackberry, bur oak, soft maple, and boxelder, singly or in combination, comprise a plurality of the stocking. Commonly found in coves and bottomlands.

Upland elm-ash-locust.--Upland forests in which elm, ash, and honeylocust, singly or in combination, comprise a plurality of the stocking. Includes shelterbelts and windbreaks on sites drier than those commonly associated with lowland species.

Gross area.--The entire area of land and water as determined by the Bureau of the Census, 1980.

Growing-stock trees.--Live trees of commercial species qualifying as desirable and acceptable trees. (Note: Excludes rough, rotten, and dead trees.)

Growing-stock volume.--Net volume in cubic feet of growing-stock trees 5 inches d.b.h. and over, from a 1 -foot stump to a minimum 4 inch top diameter outside bark of the central stem, or to the point where the central stem breaks into limbs. Cubic feet can be converted to cords by dividing by 79 cubic feet per solid wood cord.

Hardwoods.--Dicotyledonous trees, usually broadleaved and deciduous.

Idle farmland.--Includes former croplands, orchards, improved pastures, and farm sites not tended within the past 2 years and presently less than 16.7 percent stocked with trees.

Improved pasture.--Land currently improved for grazing by cultivation, seeding, irrigation, or clearing of trees or brush, and less than 16.7 percent stocked with live trees.

Indian land.--All lands held in trust by the United States for individual Indians or tribes, or all lands, titles to which are held by individual Indians or tribes, subject to Federal restrictions against alienation.

Industrial wood.--All roundwood products, except fuelwood.

Land area.--A. Bureau of the Census. The area of dry land and land temporarily or partly covered by water, such as marshes, swamps, and river flood plains (omitting tidal flats below mean high tide); streams, sloughs, estuaries, and canals less than $1 / 8$ of a statute mile wide; and lakes, reservoirs, and ponds less than 40 acres in area. 
B. Forest Inventory and Analysis. The same as the Bureau of the Census, except minimum width of streams, etc. is 120 feet and minimum size of lakes, etc. is 1 acre.

Live trees.--Growing-stock, rough and rotten trees 1 inch d.b.h. and larger.

Log grades.--A classification of logs based on external characteristics as indicators of quality or value. (See Appendix for specific grading factors used.)

Logging residues.--The unused growing-stock portions of trees cut or killed by logging.

Maintained road.--Any road, hard-topped or other surface, that is plowed or graded at least once a year. Includes rights-of-way that are cut or treated to limit herbaceous growth.

Marsh.--Nonforest land that characteristically supports low, generally herbaceous or shrubby vegetation and that is intermittently covered with water.

Merchantable.--Refers to a pulpwood or saw log section that meets pulpwood or saw log specifications, respectively.

Miscellaneous federal land.--Federal land other than National Forest, primarily land administered by the Bureau of Land Management.

Miscellaneous private land.--Privately owned land other than forest industry and farmer-owned land.

Mortality.--The volume of sound wood in growingstock and sawtimber trees that die annually.

National forest land.--Federal land that has been legally designated as National Forests or purchase units, and other land under the administration of the USDA Forest Service.

Net annual growth of growing-stock.--The annual change in volume of sound wood in live sawtimber and poletimber trees and the total volume of trees entering these classes through ingrowth, less volume losses resulting from natural causes.

Net annual growth of sawtimber.--The annual change in the volume of live sawtimber trees and the total volume of trees reaching sawtimber size, less volume losses resulting from natural causes.

Net volume.--Gross volume less deductions for rot, sweep, or other defect affecting use for timber products.

Noncommercial forest land.--(a) Unproductive forest land and (b) productive-reserved forest land. See definitions of unproductive and productive-reserved forest land.

Noncommercial species.--Tree species of typically small size, poor form, or inferior quality that normally do not develop into trees suitable for industrial wood products.

Nonforest land.--Land that has never supported forests, and land formerly forested where use for timber management is precluded by development for other uses. (Note: Includes areas used for crops, improved pasture, residential areas, city parks, improved roads of any width and adjoining clearings, powerline clearings of any width, and 1- to 40-acre areas of water classified by the Bureau of the Census as land. If intermingled in forest areas, unimproved roads and nonforest strips must be more than 120 feet wide and more than 1 acre in size to qualify as nonforest land.)

a. Nonforest land without trees.--Nonforest land with no live trees present.

b. Nonforest land with trees.--Nonforest land with one or more trees at least 5 inches in d.b.h. per acre.

Nonstocked land.--Commercial forest land less than 16.7 percent stocked with growing-stock trees.

Other removals.--Growing-stock trees removed but not utilized for products, or trees left standing but "removed" from the commercial forest land classification by land use change. Examples are removals from cultural operations such as timber stand improvement work, land clearing, and changes in land use.

Ownership.--Property owned by one owner, regardless of the number of parcels in a specified area.

Ownership size class.--The amount of commercial forest land owned by one owner, regardless of the number of parcels.

Owner tenure.--The length of time a property has been held by the owner.

Pasture and range.--Land currently improved for grazing by cultivation, seeding, or irrigation plus land on which the natural plant cover is composed principally of native grasses, forbs, or shrubs valuable for forage.

Pastured commercial forest land.--Commercial forest land for which the primary use is wood production, but presently used for grazing.

Physiographic class.--A measure of soil and water conditions that affect tree growth on a site. Physiographic classes used in Forest Inventory and Analysis inventories are:

Xeric sites.--Very dry droughty sites where excessive drainage seriously limits both growth and species occurrence. These sites are usually on upland and upper half slopes.

Xeromesic sites.--Moderately dry soils where excessive drainage limits growth and species occurrence to some extent. These sites are usually on the lower half slope.

Mesic sites.--Deep, well-drained soils. Growth and species occurrence are limited only by climate. These include all cove sites and bottomlands along intermittent streams.

Hydromesic sites.--Moderately wet soils where insufficient drainage or infrequent flooding limits growth and species occurrence to some extent. 
These include first and second bottoms on all major creeks and rivers.

Hydric sites.--Very wet sites where excess water seriously limits both growth and species occurrence.

Plant byproducts.--Plant residues used for products such as mulch, pulp chips, and fuelwood.

Plant residues.--Wood and bark materials generated at manufacturing plants during production of other products.

Poletimber stands.--(See stand-size class.)

Poletimber trees.--Growing-stock trees of commercial species at least 5 inches in d.b.h., but smaller than sawtimber size.

Productive-reserved forest land.--Forest land sufficiently productive to qualify as commercial forest land, but withdrawn from timber utilization through statute, administrative regulation, designation, or exclusive use for Christmas-tree production, as indicated by annual shearing.

Rotten trees.--Live trees of commercial species that do not contain at least one 12 -foot saw log or two saw logs 8 feet or longer, now or prospectively, because they do not meet Regional specifications for freedom from defect primarily because of rot; that is, when more than 50 percent of the cull volume in a tree is rotten.

Rough trees.--(a) Live trees of commercial species that do not contain at least one merchantable 12foot saw log or two saw logs 8 feet or longer, now or prospectively, because they do not meet Regional specifications for freedom from defect primarily because of roughness or poor form, and (b) all live trees of noncommercial species.

Roundwood products.--Logs, bolts, or other round sections (including chips from roundwood) cut from trees for industrial or consumer uses. (Note: Includes saw logs; veneer logs and bolts; cooperage logs and bolts; pulpwood; fuelwood; piling; poles; posts; hewn ties; mine timbers; and various other round; split; or hewn products.)

Salvable dead trees.--Standing or down dead trees that are considered merchantable by Regional standards.

Saplings.--Live trees 1 inch to 5 inches in d.b.h.

Sapling-seedling stands.--(See stand-size class.)

Saw log.--A log meeting minimum standards of diameter, length, and defect, including logs at least 8 feet long, sound and straight and with a minimum diameter outside bark (d.o.b.) for softwoods of 7 inches (9 inches for hardwoods) or other combinations of size and defect specified by Regional standards.

Saw log portion.--That part of the bole of sawtimber trees between the stump and the saw log top.

Saw log top.-.The point on the bole of sawtimber trees above which a saw log cannot be produced. The minimum saw log top is 7 inches d.o.b. for softwoods and 9 inches d.o.b. for hardwoods.

Sawtimber stands.--(See stand-size class.)

Sawtimber trees.--Growing-stock trees of commercial species containing at least a 12 -foot saw log or two noncontiguous saw logs 8 feet or longer, and meeting Regional specifications for freedom from defect. Softwoods must be at least 9 inches in d.b.h. Hardwoods must be at least 11 inches in d.b.h.

Sawtimber volume.--Net volume of the saw log portion of live sawtimber in board feet, International $1 / 4$-inch rule, from stump to a minimum 7 inches top d.o.b. for softwoods and a minimum 9 inches top d.o.b. for hardwoods.

Seedlings.--Live trees less than 1 inch in d.b.h. that are expected to survive. Only softwood seedlings more than 6 inches tall and hardwood seedlings more than 1 foot tall are counted.

Short-log (rough tree).--Live trees of commercial species that contain one merchantable 8- to 11 -foot saw $\log$ but not a 12 -foot saw log or two noncontiguous 8- to 11 -foot saw logs, now or prospectively.

Shrub.--A woody, perennial plant differing from a perennial herb in its persistent and woody $\operatorname{stem}(\mathrm{s})$, and less definitely from a tree in its lower stature and/or the general absence of a well-defined main stem. For this report shrubs were separated somewhat arbitrarily into tall and low shrubs as follows:

Tall shrubs.--Shrubs normally taller than 1.6 to 3.2 feet ( 0.5 to 1.0 meter).

Low shrubs.--Shrubs normally shorter than 1.6 to 3.2 feet ( 0.5 to 1.0 meter). (Woody perennial vines, such as grape, were included with low shrubs.)

Shrub biomass.--The total above-ground volume (including the bark) of selected shrubs and trees less than 1-inch d.b.h.

Site classes.--A classification of forest land in terms of inherent capacity to grow crops of industrial wood based on fully stocked natural stands.

Site index.--An expression of forest site quality based on the height of a free-growing dominant or codominant tree of a representative species in the forest type at age 50 .

Softwoods.--Coniferous trees, usually evergreen, having needles or scale-like leaves.

Stand.--A growth of trees on a minimum of 1 acre of forest land stocked by forest trees of any size.

Stand-age class.--Age of the main stand. Main stand refers to trees of the dominant forest type and stand-size class.

Stand-area class.--The extent of a continuous forested area of the same forest type, stand-size class, and stand-density class.

Stand-size class.--A classification of forest land based on the size class of growing-stock trees on the area; that is, sawtimber, poletimber, or seedlings and 
saplings.

a. Sawtimber stands.--Stands at least 16.7 percent stocked with growing-stock trees, with half or more of total stocking in sawtimber or poletimber trees, and with sawtimber stocking at least equal to poletimber stocking.

b. Poletimber stands.--Stands at least 16.7 percent stocked with growing-stock trees of which half or more of this stocking is in poletimber and/or sawtimber trees, and with poletimber stocking exceeding that of sawtimber.

c. Sapling-seedling stands.--Stands at least 16.7 percent stocked with growing-stock trees of which more than half of the stocking is saplings and/or seedlings.

d. Nonstocked stands.--Stands in which stocking of growing-stock trees is less than 16.7 percent.

State land.--Land owned by States, or land leased to these governmental units for 50 years or more.

Stocking.--The degree of occupancy of land by trees, measured by basal area and/or the number of trees in a stand by size or age and spacing, compared to the basal area and/or number of trees required to fully utilize the growth potential of the land; that is, the stocking standard.

A stocking percent of 100 indicates full utilization of the site and is equivalent to 80 square feet of basal area per acre in trees 5 inches d.b.h. and larger. In a stand of trees less than 5 inches d.b.h., a stocking percent of 100 would indicate that the present number of trees is sufficient to produce 80 square feet of basal area per acre when the trees reach 5 inches d.b.h.

Stands are grouped into the following stocking classes:

Overstocked stands.--Stands in which stocking of trees is 134.0 percent or more.

Fully stocked stands.--Stands in which stocking of trees is from 101.0 to 133.9 percent.

Medium stocked stands.--Stands in which stocking of trees is from 61.0 to 100.9 percent.

Poorly stocked stands.--Stands in which stocking of trees is from 16.7 to 60.9 percent.

Nonstocked areas.--Commercial forest land on which stocking of trees is less than 16.7 percent.

Timber removals from growing stock.--The volume of sound wood in growing-stock trees removed annually for forest products (including roundwood products and logging residues) and for other removals.

Timber removals from sawtimber.--The net board-foot volume of live sawtimber trees removed for forest products annually (including roundwood products and logging residues) and for other removals.

Timber products output.--All timber products cut from roundwood and byproducts of wood manufacturing plants. Roundwood products include logs, bolts, or other round sections cut from growingstock trees, cull trees, salvable dead trees, trees on nonforest land, noncommercial species, sapling-size trees, and limbwood. Byproducts from primary manufacturing plants include slabs, edging, trimmings, miscuts, sawdust, shavings, veneer cores and clippings, and screenings of pulpmills that are used as pulpwood chips or other products.

Tree biomass.--The total aboveground volume (including the bark) of all trees 1 to 5 inches in d.b.h., and the total aboveground volume (including the bark) from a 1 -foot stump for trees more than 5 inches in d.b.h.

Tree size class.--A classification of trees based on diameter at breast height, including sawtimber trees, poletimber trees, saplings, and seedlings.

Unproductive forest land.--Forest land incapable of producing 20 cubic feet per acre of annual growth or of yielding crops of industrial wood under natural conditions because of adverse site conditions. (Note: Adverse conditions include shallow soils, dry climate, poor drainage, high elevation, steepness, and rockiness.)

Upper stem portion.--That part of the bole of sawtimber trees above the saw log top to a minimum top diameter of 4 inches outside bark or to the point where the central stem breaks into limbs.

Urban and other areas.--Areas within the legal boundaries of cities, and towns; suburban areas developed for residential, industrial, or recreational purposes; schoolyards; cemeteries; roads, railroads, airports; beaches; powerlines; and other rights-ofway; or other nonforest land not included in any other specified land use class.

Water.--(a) Bureau of the Census. - Streams, sloughs, estuaries, and canals more than one-eighth of a statute mile wide, and lakes, reservoirs, and ponds more than 40 acres in area.

(b) Noncensus.--The same as the Bureau of the Census, except minimum width of streams, etc. is 120 feet and minimum size of lakes, etc. is 1 acre.

Windbreak.--A group of trees less than 120 feet wide used for the protection of soil, cropfields, and buildings in use.

Wooded pasture.--Improved pasture with more than 16.7 percent stocking in live trees, but less than 25 percent stocking in growing-stock trees. Area is currently improved for grazing or there is other evidence of grazing. (Nonforest land with trees).

Wooded strip.--An acre or more of natural continuous forest land that would otherwise meet survey standards for commercial forest land except that it is less than 120 feet wide. (Nonforest land with trees). 


\section{TEXT TABLES}

Table 1.--Area of commercial forest land by forest type and physiographic class

Table 2.--Net volume of growing stock and sawtimber in 1965 and 1981 by Forest Survey Unit and change since 1965

Table 3.--Net volume of timber on commercial forest land by class of timber and softwoods and hardwoods

Table 4.--Net volume of black walnut by land class and tree class

Table 5.--Estimation of potential net annual growth on commercial forest land

Table 6.--Biomass yields on commercial forest land by forest type and vegetation component

\section{AREA}

Table 7.--Area of land by land class, 1965 and 1981

Table 8.--Area of land by land class and Forest Survey Unit

Table 9.--Area of land and forest land by county

Table 10.--Area of commercial forest land by ownership class and Forest Survey Unit

Table 11.--Area of commercial forest land by ownership class and forest type

Table 12.--Area of commercial forest land by ownership class and site class

Table 13.--Area of commercial forest land by ownership class and ownership-size class

Table 14.--Area of commercial forest land by ownership class, stand-size class, and Forest Survey Unit

Table 15.--Area of commercial forest land by ownership class and area-condition class

Table 16.--Area of commercial forest land by ownership class and stand-volume class

Table 17.--Area of commercial forest land by county and forest type

Table 18.--Area of commercial forest land by forest type and stand-age class

Table 19.--Area of commercial forest land by forest type, stand-size class, and Forest Survey Unit

Table 20.--Area of commercial forest land by forest type, stand-size class, and site class

Table 21.--Area of commercial forest land by forest type, stand-size class, and stocking percent

Table 22.--Area of commercial forest land by forest type, site-index class, and Forest Survey Unit

Table 23.--Area of commercial forest land by forest type and basal-area class

Table 24.--Area of commercial forest land by forest type and distance to road
Table 25.--Area of commercial forest land by forest type and distance to water

Table 26.--Area of commercial forest land by forest type and stand-area class

Table 27.--Area of commercial forest land by stocking class based on selected stand components

Table 28.--Area of commercial forest land by forest type, physiographic class, and ownership class

Table 29.--Area of noncommercial forest land by ownership class

Table 30.--Area of noncommercial forest land by forest type and Forest Survey Unit

Table 31.--Area of nonforest land with trees by land use, forest type and Forest Survey Unit

Table 32.--Area of nonforest land with trees by forest type and stand-size class

Table 33.--Area of windbreaks by forest type, standsize class, and Forest Survey Unit

Table 34.--Area of wooded strips by forest type, standsize class, and ownership class

Table 35.--Area of wooded strips by forest type and site-index class

Table 36.--Area of wooded strips by forest type, basalarea class, and Forest Survey Unit

Table 37.--Area of wooded strips by forest type and stand-age class

Table 38.--Area of wooded strips by forest type, physiographic class, and ownership class

Table 39.--Area of wooded strips in private ownership by ownership class, owner tenure, and ownershipsize class

\section{NUMBER OF TREES}

Table 40.--Number of all live trees on commercial forest land by species group and diameter class

Table 41.--Number of growing-stock trees on commercial forest land by species group and diameter class

Table 42.--Number of short-log trees on commercial forest land by species group and diameter class

\section{VOLUME}

Table 43.--Net volume of growing stock and sawtimber on commercial forest land by species group, 1965 and 1981

Table 44.--Net volume of all live trees on commercial forest land by species group and diameter class

Table 45.--Net volume of timber on commercial forest land by class of timber and softwoods and hardwoods 
Table 46.--Net volume of growing-stock, sawtimber, short-log, and rough and rotten trees on commercial forest land by individual species

Table 47.--Net volume of noncommercial species (nongrowing-stock volume) on commercial forest land by individual species

Table 48.--Net volume of growing stock on commercial forest land by species group and Forest Survey Unit

Table 49.--Net volume of sawtimber on commercial forest land by species group and Forest Survey Unit

Table 50.--Net volume of growing stock on commercial forest land by county and species group

Table 51.--Net volume of sawtimber on commercial forest land by county and species group

Table 52.--Net volume of growing stock on commercial forest land by species group and diameter class

Table 53.--Net volume of sawtimber on commercial forest land by species group and diameter class

Table 54.--Net volume of growing stock on commercial forest land by species group and forest type

Table 55.--Net volume of sawtimber on commercial forest land by species group and forest type

Table 56.--Net volume of growing stock on commercial forest land by species group and ownership class

Table 57.--Net volume of sawtimber on commercial forest land by species group and ownership class

Table 58.--Net volume of growing stock on commercial forest land by forest type and stand-age class

Table 59.--Net volume of sawtimber on commercial forest land by forest type and stand-age class

Table 60.--Net volume of growing stock on commercial forest land by forest type, stand-size class, and basal-area class

Table 61.--Net volume of sawtimber on commercial forest land by forest type, stand-size class, and basal-area class

Table 62.--Net volume of sawtimber on commercial forest land by species group and butt log-grade class

Table 63.--Net volume of growing-stock trees by forest type and ground land use

Table 64.--Net volume of black walnut by land class and tree class

Table 65.--Net volume of growing-stock and short-log trees on commercial forest land and wooded strips by species group and Forest Survey Unit

Table 66.--Net volume of sawtimber and short-log trees on commercial forest land and wooded strips by species group and Forest Survey Unit

Table 67.--Net volume of short-log trees on commercial forest land by species group and diameter class (In thousand cubic feet)

Table 68.--Net volume of short-log trees on commercial forest land by species group and diameter class (In thousand board feet)

Table 69.--Net volume of all live trees on wooded strips by species group and diameter class
Table 70.--Net volume of sawtimber on wooded strips by species group and diameter class

Table 71.--Net volume of short-log trees on wooded strips by species group and diameter class

Table 72.--Net volume of growing stock on wooded strips by species group and forest type

Table 73.--Net volume of sawtimber on wooded strips by species group and forest type

\section{GROWTH AND REMOVALS}

Table 74.--Net annual growth of growing stock on commercial forest land by softwoods and hardwoods, 1964 and 1980

Table 75.--Net annual growth of growing stock on commercial forest land by species group and Forest Survey Unit

Table 76.--Net annual growth of sawtimber on commercial forest land by species group and Forest Survey Unit

Table 77.--Net annual growth of growing stock on commercial forest land by species group and ownership class

Table 78.--Net annual growth of sawtimber on commercial forest land by species group and ownership class

Table 79.--Net annual growth of growing stock on commercial forest land by species group and forest type

Table 80.--Net annual growth of sawtimber on commercial forest land by species group and forest type

Table 81. - Net annual growth of growing stock on commercial forest land by forest type and stand-age class

Table 82.--Net annual growth of sawtimber on commercial forest land by forest type and stand-age class

Table 83.--Net annual growth of growing stock on commercial forest land by forest type, stand-size class, and basal-area class

Table 84.--Net annual growth of sawtimber on commercial forest land by forest type, stand-size class, and basal-area class

Table 85.--Net annual growth of growing stock on wooded strips by species group and Forest Survey Unit

Table 86.--Net annual growth of sawtimber on wooded strips by species group and Forest Survey Unit

Table 87.--Timber removals from growing stock on commercial forest land by species group and Forest Survey Unit

Table 88.--Timber removals from sawtimber on commercial forest land by species group and Forest Survey Unit

Table 89.--Timber removals from growing stock and sawtimber on commercial forest land by species 
group, 1964 and 1980

Table 90.--Timber removals from growing stock and sawtimber on commercial forest land by item and species category

Table 91.--Net annual growth and removals of growing stock on commercial forest land by species group

Table 92.--Net annual growth and removals of sawtimber on commercial forest land by species group

Table 93.--Net annual growth and removals of growing stock on commercial forest land by ownership class and softwoods and hardwoods

Table 94.--Net annual growth and removals of sawtimber on commercial forest land by ownership class and softwoods and hardwoods

\section{MORTALITY}

Table 95.--Annual mortality of growing stock on commercial forest land by softwoods and hardwoods, 1964 and 1980

Table 96.--Annual mortality of growing stock on commercial forest land by species group and cause

Table 97.--Annual mortality of sawtimber on commercial forest land by species group and cause

Table 98.--Annual mortality of growing stock and sawtimber on commercial forest land by ownership class and softwoods and hardwoods

\section{UTILIZATION}

Table 99.--Output of timber products by product, softwoods and hardwoods, and source of material

Table 100.--Output of roundwood products by product, softwoods and hardwoods, and source of material

Table 101.--Timber products from roundwood by species group and product

Table 102.--Volume of primary plant residue by type of use and kind of material

\section{BIOMASS}

Table 103.--All live shrub biomass yields on commercial forest land by shrub species group and forest type

Table 104.--All live tree biomass yields on commercial forest land by species group and forest type (pounds per acre)

Table 105.--All live tree biomass on commercial forest land by species group and forest type (green tons)

Table 106.--All live tree biomass weight by species group and tree biomass component (green tons)

Table 107.--All live tree biomass volume by species group and tree biomass component (thousand cubic feet)

\section{PROJECTIONS}

Table 108.--Removals, net annual growth, and inventory of growing stock on commercial forest land, 1981, and low removals option projections to 2011

Table 109.--Removals, net annual growth and inventory of growing stock on commercial forest land, 1981, and high removals option projections to 2011

\section{SAMPLING ERRORS}

Table 110.--Sampling errors for estimates smaller than the State totals of volume, net growth, removals and area of commercial forest land

Table 111.--Sampling errors for estimates smaller than the Survey Unit totals of volume, net growth, removals, and area of commercial forest land, Northeastern Survey Unit

Table 112.--Sampling errors for estimates smaller than the Survey Unit totals of volume, net growth, removals, and area of commercial forest land, Southeastern Survey Unit

Table 113.--Sampling errors for estimates smaller than the Survey Unit totals of volume, net growth, removals, and area of commercial forest land, Western Survey Unit 
Table 7.--Area of land by land class, Kansas, 1965 and 1981

(In thousand acres)

\begin{tabular}{lrr}
\hline Land class & $19651 /$ & 1981 \\
\hline Forest land & & \\
Commercial forest land & 2.7 & 27.5 \\
Eastern redcedar-hardwood & 185.3 & 316.6 \\
Oak-hickory & 27.3 & 30.9 \\
Post-blackjack oak & 113.1 & 49.4 \\
Upland plains hardwoods & 192.9 & 289.6 \\
Elm-ash-cottonwood & 65.0 & 68.1 \\
Cottonwood & 8.7 & 4.2 \\
Willow & 220.7 & 265.9 \\
Lowland plains hardwoods & 228.6 & 110.3 \\
Upland elm-ash-locust & 147.2 & 45.4 \\
Nonstocked & $1,191.5$ & $1,207.9$ \\
Subtotal & 157.4 & 128.4 \\
Noncommercial forest 1and & 0.9 & 22.4 \\
Unproductive & 158.3 & 150.8 \\
Productive-reserved & $1,349.8$ & $1,358.7$ \\
Subtotal & $51,160.9$ & $50,979.3$ \\
\hline Total & $52,510.7$ & $52,338.0$ \\
\hline Nonforest land & & \\
\hline All land & & \\
\hline
\end{tabular}


Table 8.--Area of land by land class and Forest Survey Unit, Kansas, 1981 (In thousand acres)

\begin{tabular}{|c|c|c|c|c|}
\hline \multirow[b]{2}{*}{ Land class } & \multirow[b]{2}{*}{$\begin{array}{c}\text { A } 11 \\
\text { units }\end{array}$} & \multicolumn{3}{|c|}{ Forest Survey Unit } \\
\hline & & $\begin{array}{c}\text { North- } \\
\text { eastern } \\
\text { unit } \\
\end{array}$ & $\begin{array}{c}\text { South- } \\
\text { eastern } \\
\text { unit } \\
\end{array}$ & $\begin{array}{c}\text { Western } \\
\text { unit }\end{array}$ \\
\hline \multicolumn{5}{|l|}{ FOREST LAND } \\
\hline Commercial forest land & & & & \\
\hline $\begin{array}{l}\text { Unpastured commercial forest } \\
\text { Pastured commercial forest } 1 /\end{array}$ & $\begin{array}{l}825.1 \\
382.8 \\
\end{array}$ & $\begin{array}{l}401.4 \\
186.7\end{array}$ & $\begin{array}{l}284.5 \\
152.5\end{array}$ & $\begin{array}{r}139.2 \\
43.6\end{array}$ \\
\hline Subtotal & $1,207.9$ & 588.1 & 437.0 & 182.8 \\
\hline $\begin{array}{l}\text { Noncommercial forest land } \\
\text { Unproductive } \\
\text { Productive-reserved }\end{array}$ & $\begin{array}{r}128.4 \\
22.4 \\
\end{array}$ & $\begin{array}{l}21.0 \\
15.1 \\
\end{array}$ & $\begin{array}{r}97.0 \\
2.3 \\
\end{array}$ & $\begin{array}{r}10.4 \\
5.0 \\
\end{array}$ \\
\hline Subtotal & 150.8 & 36.1 & 99.3 & 15.4 \\
\hline Total & $1,358.7$ & 624.2 & 536.3 & 198.2 \\
\hline \multicolumn{5}{|l|}{ NONFOREST LAND } \\
\hline $\begin{array}{l}\text { Nonforest with trees } \\
\text { Cropland } \\
\text { Improved pasture?/ } \\
\text { Wooded strips3/ } \\
\text { Idle farmland } \\
\text { Marsh } \\
\text { Windbreaks 4/ } \\
\text { Wooded pasture2/ }\end{array}$ & $\begin{array}{r}63.0 \\
533.6 \\
150.0 \\
23.9 \\
22.7 \\
186.3 \\
209.8 \\
\end{array}$ & $\begin{array}{r}30.2 \\
139.4 \\
62.6 \\
4.1 \\
4.2 \\
43.0 \\
60.5 \\
\end{array}$ & $\begin{array}{r}13.6 \\
225.2 \\
50.3 \\
2.5 \\
4.3 \\
66.9 \\
95.2 \\
\end{array}$ & $\begin{array}{r}19.2 \\
169.0 \\
37.1 \\
17.3 \\
14.2 \\
76.4 \\
54.1 \\
\end{array}$ \\
\hline Subtotal & $1,189.3$ & 344.0 & 458.0 & 387.3 \\
\hline $\begin{array}{l}\text { Nonforest without trees } \\
\text { Cropland } \\
\text { Improved pasture2/ } \\
\text { Idle farml and } \\
\text { Marsh } \\
\text { Other farm-farmstead } \\
\text { Urban and other } \\
\text { Noncensus water }\end{array}$ & $\begin{array}{r}32,163.2 \\
15,827.4 \\
7.5 \\
56.3 \\
198.9 \\
1,417.9 \\
118.8 \\
\end{array}$ & $\begin{array}{r}5,026.1 \\
1,922.7 \\
2.9 \\
1.5 \\
67.0 \\
374.3 \\
32.2 \\
\end{array}$ & $\begin{array}{r}3,850.3 \\
4,549.0 \\
4.6 \\
6.9 \\
35.4 \\
338.5 \\
34.3 \\
\end{array}$ & $\begin{array}{r}23,286.8 \\
9,355.7 \\
0 \\
47.9 \\
96.5 \\
705.1 \\
52.3 \\
\end{array}$ \\
\hline Subtota 1 & $49,790.0$ & $7,426.7$ & $8,819.0$ & $33,544.3$ \\
\hline Total & $50,979.3$ & $7,770.7$ & $9,277.0$ & $33,931.6$ \\
\hline TOTAL LAND $5 /$ & $52,338.0$ & $8,394.9$ & $9,813.3$ & $34,129.8$ \\
\hline WATER (BUREAU OF THE CENSUS) 5 / & 319.5 & 155.9 & 77.5 & 86.1 \\
\hline TOTAL LAND AND WATER / & $52,657.5$ & $8,550.8$ & $9,890.8$ & $34,215.9$ \\
\hline
\end{tabular}

$1 /$ Forest land for which the primary use is wood production, but is used for grazing.

2. Includes areas classified as range by the USDA Soil Conservation Service.

3 An acre or more of natural continuous forest land less than 120 feet wide that woulg otherwise meet survey standards.

- A group of trees less than 120 feet wide used for the protection of soil, cropfields, and buildings in use.

- U.S. Department of Commerce, Bureau of the Census. 1980. State/county area measurement reports (unpublished). 


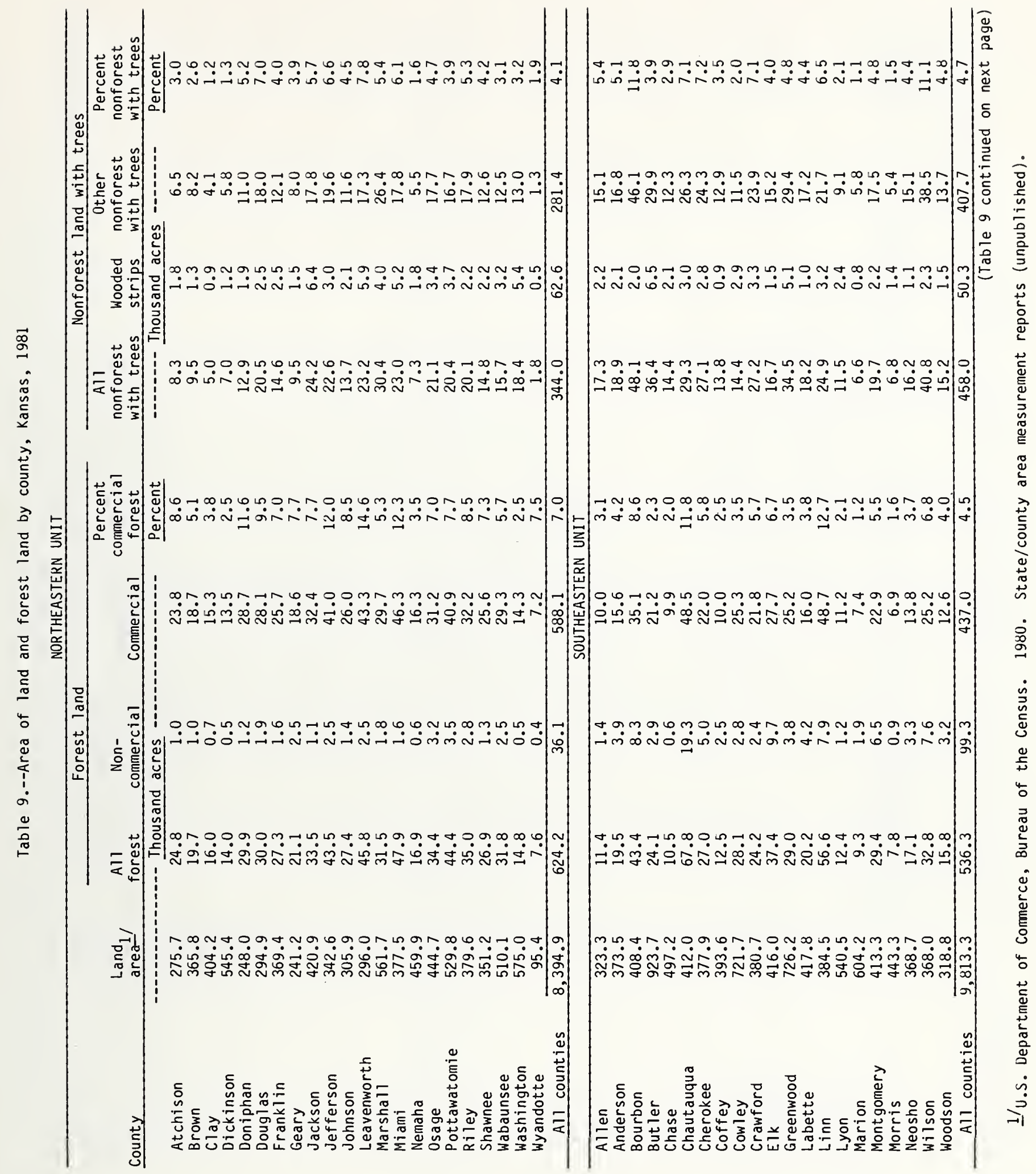




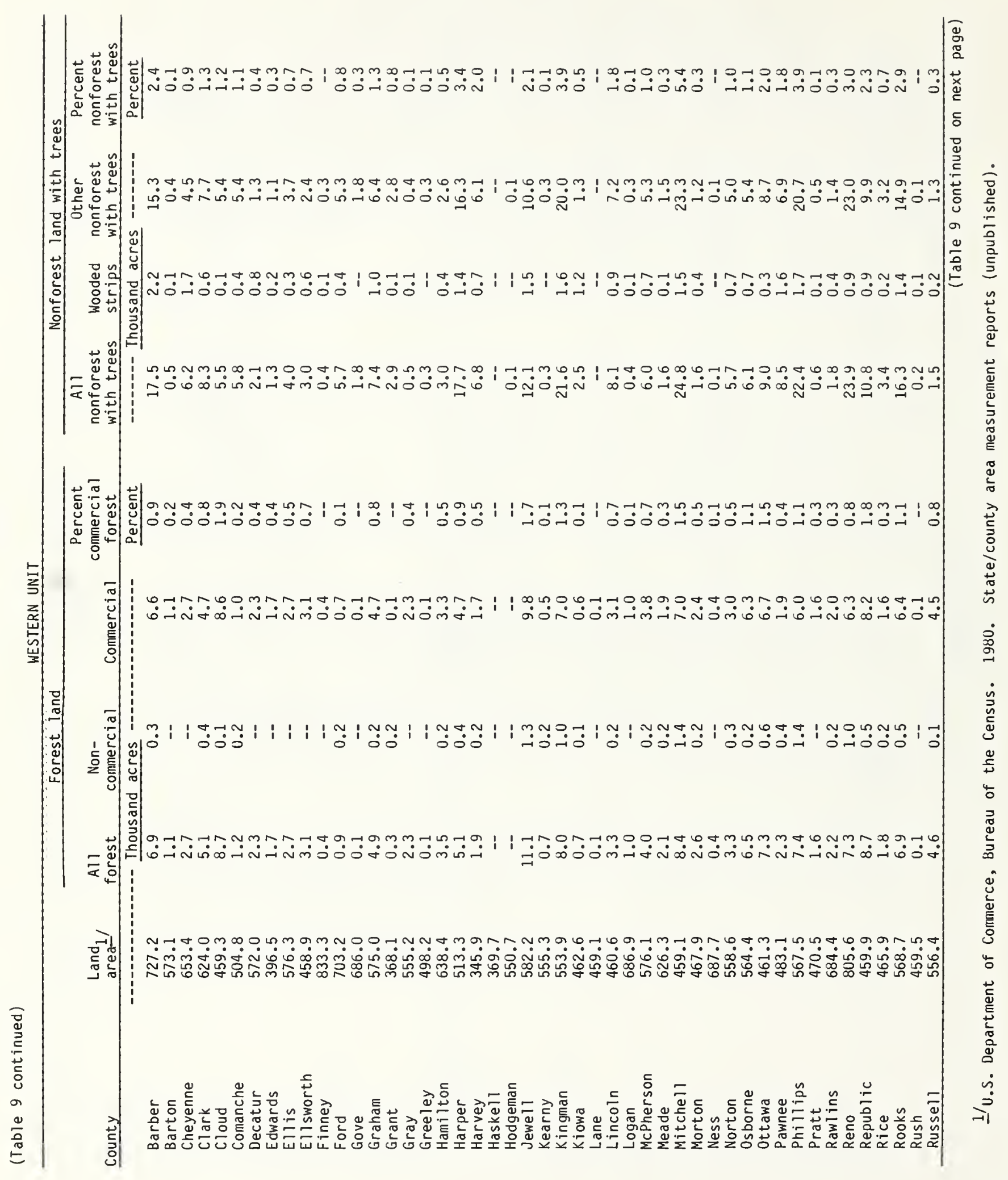



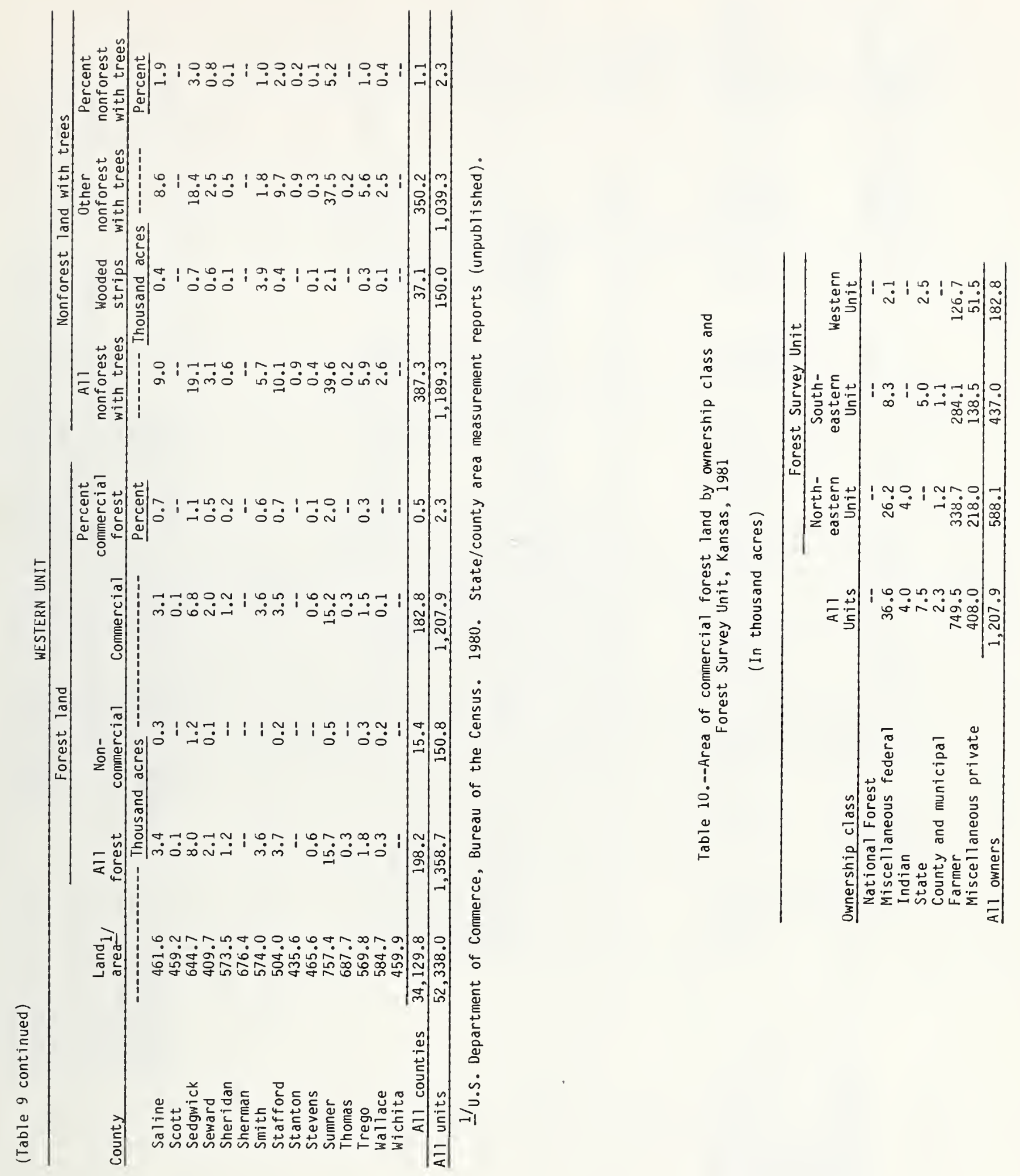


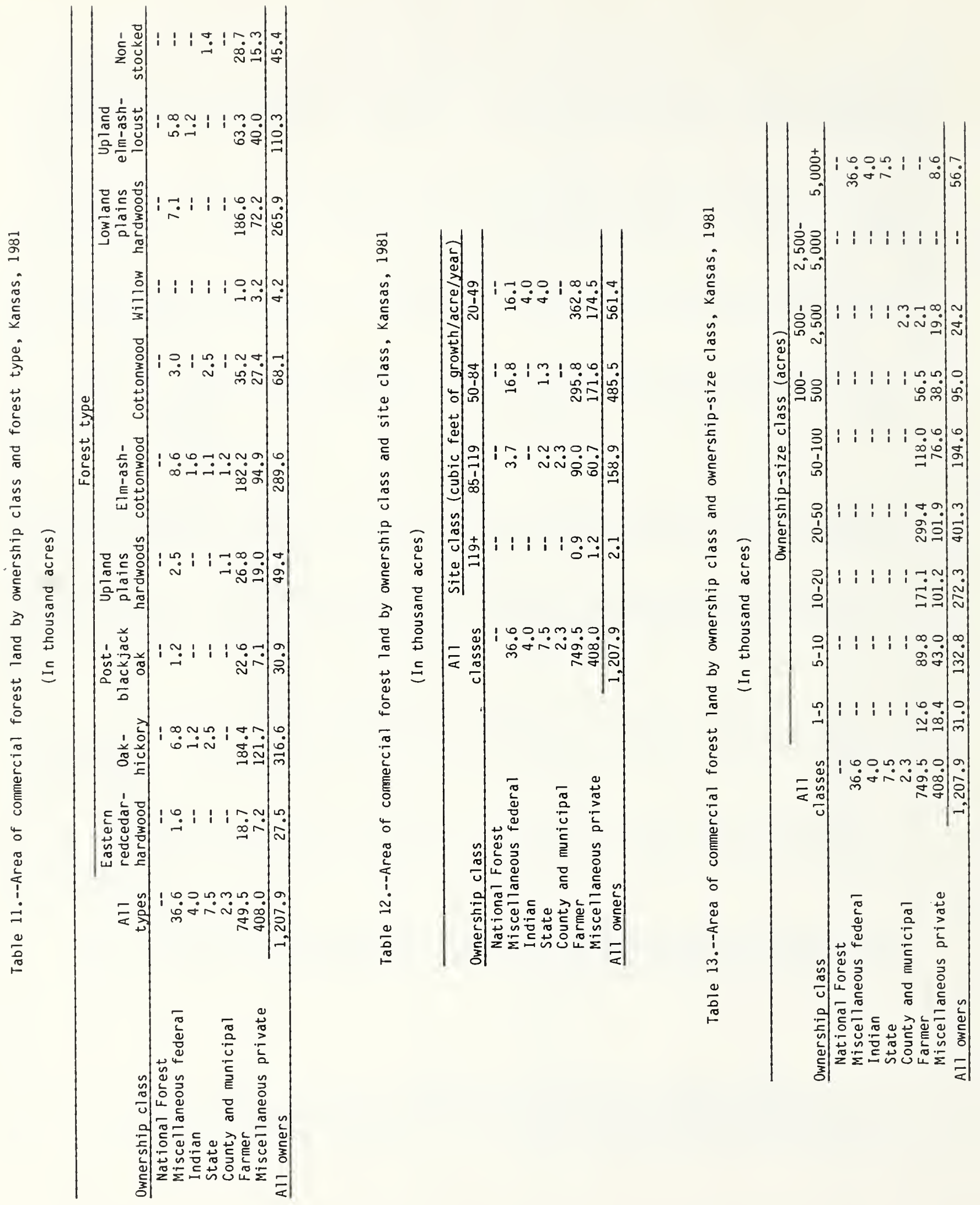


Table 14.--Area of commercial forest land by ownership class, stand-size class, and Forest Survey Unit, Kansas, 1981

(In thousand acres)

ALL UNITS

\begin{tabular}{|c|c|c|c|c|c|}
\hline \multirow[b]{2}{*}{ Ownership class } & \multirow[b]{2}{*}{$\begin{array}{l}\text { Al1 } \\
\text { stands }\end{array}$} & \multicolumn{4}{|c|}{ Stand-size class } \\
\hline & & $\begin{array}{c}\text { Sawt imber } \\
\text { stands }\end{array}$ & $\begin{array}{c}\text { Poletimber } \\
\text { stands }\end{array}$ & $\begin{array}{c}\text { Sapling and } \\
\text { seedling stands }\end{array}$ & $\begin{array}{c}\text { Nons tocked } \\
\text { areas }\end{array}$ \\
\hline $\begin{array}{l}\text { National Forest } \\
\text { Miscellaneous federal } \\
\text { Indian } \\
\text { State } \\
\text { County and municipal } \\
\text { Farmer } \\
\text { Miscellaneous private }\end{array}$ & $\begin{array}{r}-\overline{-} \\
36.6 \\
4.0 \\
7.5 \\
2.3 \\
749.5 \\
408.0 \\
\end{array}$ & $\begin{array}{r}-- \\
18.1 \\
1.2 \\
3.6 \\
2.3 \\
357.0 \\
182.8 \\
\end{array}$ & $\begin{array}{r}-\overline{-} \\
4.4 \\
-\overline{2 .} \\
2.5 \\
-\overline{-} \\
139.7 \\
87.8 \\
\end{array}$ & $\begin{array}{r}-\overline{-} \\
14.1 \\
2.8 \\
-- \\
-- \\
224.1 \\
122.1 \\
\end{array}$ & $\begin{array}{r}-- \\
-- \\
-- \\
1.4 \\
-- \\
28.7 \\
15.3\end{array}$ \\
\hline All owners & $1,207.9$ & 565.0 & 234.4 & 363.1 & 45.4 \\
\hline \multicolumn{6}{|c|}{ NORTHEASTERN UNIT } \\
\hline $\begin{array}{l}\text { National Forest } \\
\text { Miscellaneous federal } \\
\text { Indian } \\
\text { State } \\
\text { County and municipal } \\
\text { Farmer } \\
\text { Miscellaneous private }\end{array}$ & $\begin{array}{r}-\overline{-} \\
26.2 \\
4.0 \\
-- \\
1.2 \\
338.7 \\
218.0 \\
\end{array}$ & $\begin{array}{r}-\overline{-} \\
13.4 \\
1.2 \\
-\overline{-} \\
1.2 \\
146.3 \\
80.9 \\
\end{array}$ & $\begin{array}{r}-- \\
1.1 \\
-- \\
-- \\
-- \\
62.0 \\
49.2 \\
\end{array}$ & $\begin{array}{r}-\overline{-} \\
11.7 \\
2.8 \\
-- \\
-- \\
116.3 \\
82.7\end{array}$ & $\begin{array}{r}-- \\
-- \\
-- \\
-- \\
-- \\
14.1 \\
5.2\end{array}$ \\
\hline All owners & 588.1 & 243.0 & 112.3 & 213.5 & 19.3 \\
\hline \multicolumn{6}{|c|}{ SOUTHEASTERN UNIT } \\
\hline $\begin{array}{l}\text { National Forest } \\
\text { Miscellaneous federal } \\
\text { Indian } \\
\text { State } \\
\text { County and municipal } \\
\text { Farmer } \\
\text { Miscellaneous private }\end{array}$ & $\begin{array}{r}-\overline{8.3} \\
-- \\
5.0 \\
1.1 \\
284.1 \\
138.5 \\
\end{array}$ & $\begin{array}{r}-\overline{-} \\
4.7 \\
-- \\
3.6 \\
1.1 \\
127.0 \\
56.0 \\
\end{array}$ & $\begin{array}{r}-- \\
1.2 \\
-- \\
-- \\
-- \\
58.9 \\
36.5\end{array}$ & $\begin{array}{r}-- \\
2.4 \\
-- \\
-- \\
-- \\
94.1 \\
35.9\end{array}$ & $\begin{array}{r}-- \\
-- \\
-- \\
1.4 \\
-- \\
4.1 \\
10.1\end{array}$ \\
\hline All owners & 437.0 & 192.4 & 96.6 & 132.4 & 15.6 \\
\hline \multicolumn{6}{|c|}{ WESTERN UNIT } \\
\hline $\begin{array}{l}\text { National Forest } \\
\text { Miscellaneous federal } \\
\text { Indian } \\
\text { State } \\
\text { County and municipal } \\
\text { Farmer } \\
\text { Miscellaneous private }\end{array}$ & $\begin{array}{r}-\overline{2.1} \\
-- \\
2.5 \\
-\overline{--} \\
126.7 \\
51.5\end{array}$ & $\begin{array}{r}-- \\
-- \\
-- \\
-- \\
-- \\
83.7 \\
45.9\end{array}$ & $\begin{array}{r}-- \\
2.1 \\
-- \\
2.5 \\
-- \\
18.8 \\
2.1\end{array}$ & $\begin{array}{r}-- \\
-- \\
-- \\
-- \\
-- \\
13.7 \\
3.5\end{array}$ & $\begin{array}{r}-- \\
-- \\
-- \\
-- \\
-- \\
10.5 \\
--\end{array}$ \\
\hline All owners & 182.8 & 129.6 & 25.5 & 17.2 & 10.5 \\
\hline
\end{tabular}


Table 15.--Area of commercial forest land by ownership class and area-condition class, Kansas, 1981

(In thousand acres)

\begin{tabular}{lrrrrr} 
& & \multicolumn{4}{c}{ Area-condition class } \\
\cline { 3 - 5 } Ownership class & All & & & \multicolumn{1}{c}{ cla or } \\
classes & -- & -- & -- & -- & -- \\
National Forest & 36.6 & 8.9 & 23.3 & 4.4 & -- \\
Miscellaneous federal & 4.0 & 4.0 & -- & -- & -- \\
Indian & 7.5 & 1.5 & 5.0 & 1.0 & -- \\
State & 2.3 & -- & 2.3 & -- & -- \\
County and municipal & 749.5 & 360.9 & 335.0 & 53.6 & -- \\
Farmer & 408.0 & 179.2 & 183.8 & 45.0 & -- \\
Miscellaneous private & $1,207.9$ & 554.5 & 549.4 & 104.0 & -- \\
All owners & & &
\end{tabular}

Table 16.--Area of commercial forest land by ownership class and stand-volume class, Kansas, 1981 (In thousand acres)

\begin{tabular}{|c|c|c|c|c|}
\hline \multirow[b]{2}{*}{ Ownership class } & \multirow[b]{2}{*}{$\begin{array}{c}\text { A11 } \\
\text { classes }\end{array}$} & \multicolumn{3}{|c|}{ Stand-volume class (board feet $1 /$ per acre) } \\
\hline & & $\begin{array}{c}\text { Less than } \\
1,500\end{array}$ & $\begin{array}{c}1,500 \text { to } \\
5,000\end{array}$ & $5,000+$ \\
\hline $\begin{array}{l}\text { National Forest } \\
\text { Miscellaneous federal } \\
\text { Indian } \\
\text { State } \\
\text { County and municipal } \\
\text { Farmer } \\
\text { Miscellaneous private }\end{array}$ & $\begin{array}{r}-- \\
36.6 \\
4.0 \\
7.5 \\
2.3 \\
749.5 \\
408.0 \\
\end{array}$ & $\begin{array}{r}-\overline{-} \\
15.8 \\
2.8 \\
4.0 \\
-- \\
401.6 \\
221.4 \\
\end{array}$ & $\begin{array}{r}-- \\
12.4 \\
1.2 \\
-- \\
1.2 \\
274.5 \\
139.6 \\
\end{array}$ & $\begin{array}{r}-\overline{-} \\
8.4 \\
-- \\
3.5 \\
1.1 \\
73.4 \\
47.0 \\
\end{array}$ \\
\hline Al1 owners & $1,207.9$ & 645.6 & 428.9 & 133.4 \\
\hline
\end{tabular}

1/International $1 / 4$-inch rule. 


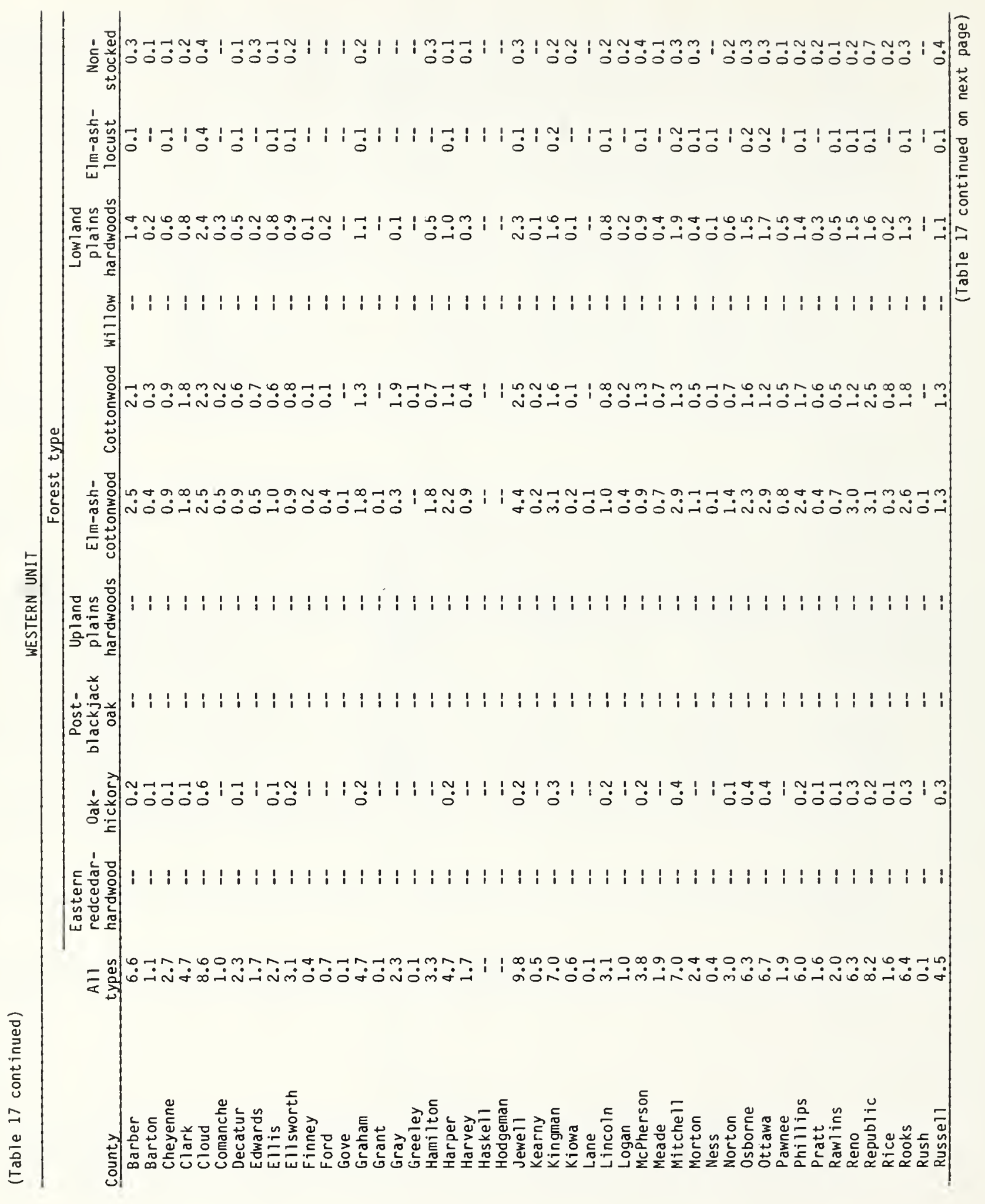



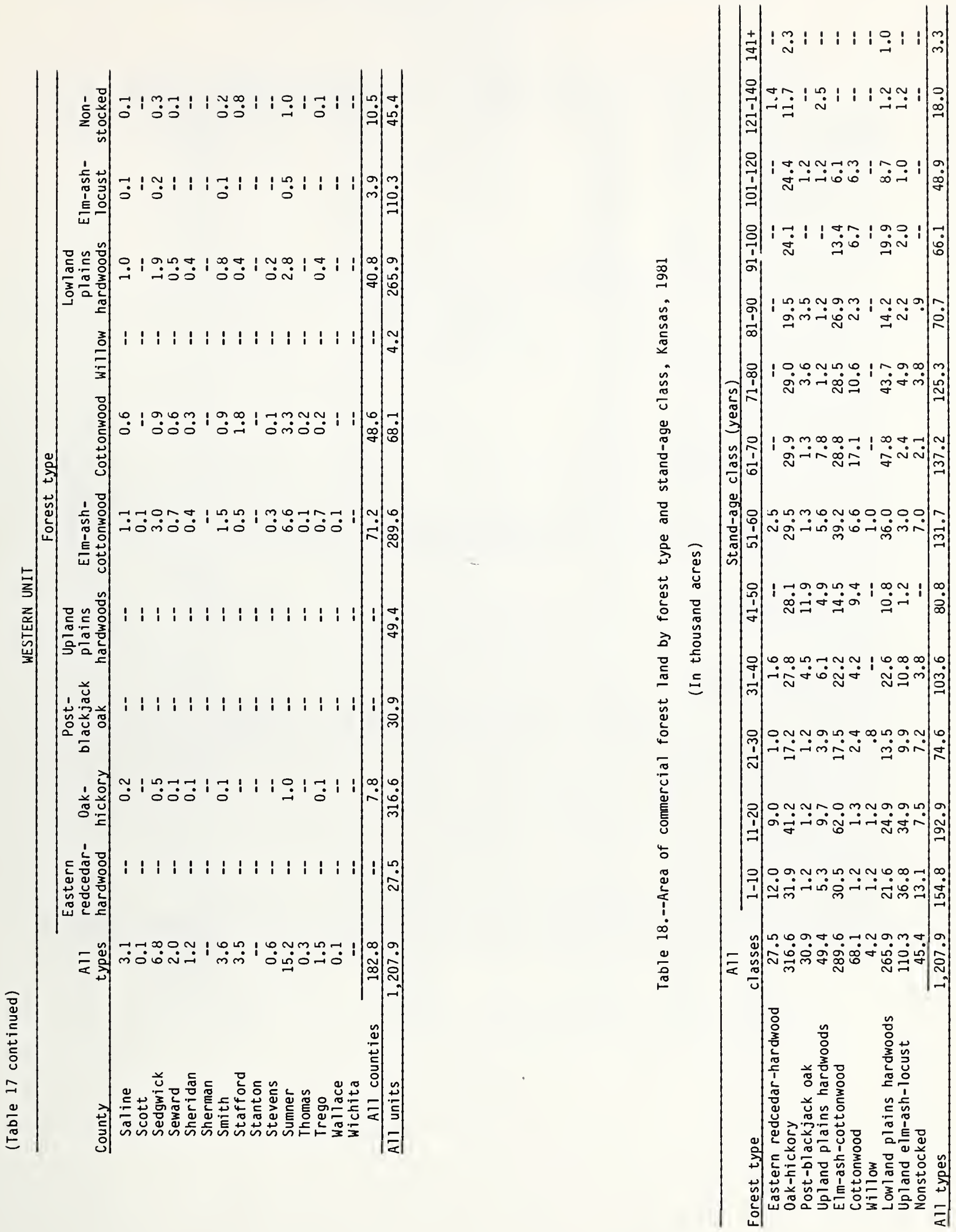
Table 19.--Area of commercial forest land by forest type, stand-size class, and Forest Survey Unit, Kansas, 1981

(In thousand acres)

ALL UNITS

\begin{tabular}{|c|c|c|c|c|c|}
\hline \multirow[b]{2}{*}{ Forest type } & \multirow[b]{2}{*}{$\begin{array}{c}\text { All } \\
\text { stands }\end{array}$} & \multicolumn{4}{|c|}{ Stand-size class } \\
\hline & & $\begin{array}{c}\text { Sawtimber } \\
\text { stands }\end{array}$ & $\begin{array}{c}\text { Poletimber } \\
\text { stands }\end{array}$ & $\begin{array}{l}\text { Sapling and } \\
\text { seedling stands }\end{array}$ & $\begin{array}{c}\begin{array}{c}\text { Nonstocked } \\
\text { areas }\end{array} \\
\end{array}$ \\
\hline $\begin{array}{l}\text { Eastern redcedar-hardwood } \\
\text { 0ak-hickory } \\
\text { Post-blackjack oak } \\
\text { Upland plains hardwoods } \\
\text { Elm-ash-cottonwood } \\
\text { Cottonwood } \\
\text { Willow } \\
\text { Lowl and plains hardwoods } \\
\text { Upland elm-ash-locust } \\
\text { Nonstocked }\end{array}$ & $\begin{array}{r}27.5 \\
316.6 \\
30.9 \\
49.4 \\
289.6 \\
68.1 \\
4.2 \\
265.9 \\
110.3 \\
45.4 \\
\end{array}$ & $\begin{array}{r}2.7 \\
141.9 \\
8.5 \\
18.7 \\
145.1 \\
59.6 \\
1.0 \\
170.7 \\
16.8 \\
--\end{array}$ & $\begin{array}{r}2.8 \\
84.0 \\
17.6 \\
16.8 \\
47.0 \\
4.9 \\
0.8 \\
46.7 \\
13.8 \\
--\end{array}$ & $\begin{array}{r}22.0 \\
90.7 \\
4.8 \\
13.9 \\
97.5 \\
3.6 \\
2.4 \\
48.5 \\
79.7 \\
--\end{array}$ & $\begin{array}{l}-- \\
-- \\
-- \\
-- \\
-- \\
-- \\
-- \\
-- \\
-- \\
45.4\end{array}$ \\
\hline All types & $1,207.9$ & 565.0 & 234.4 & 363.1 & 45.4 \\
\hline \multicolumn{6}{|c|}{ NORTHEASTERN UNIT } \\
\hline $\begin{array}{l}\text { Eastern redcedar-hardwood } \\
\text { Oak-hickory } \\
\text { Post-blackjack oak } \\
\text { Upland plains hardwoods } \\
\text { Elm-ash-cottonwood } \\
\text { Cottonwood } \\
\text { Willow } \\
\text { Lowland plains hardwoods } \\
\text { Upland elm-ash-locust } \\
\text { Nonstocked }\end{array}$ & $\begin{array}{r}15.9 \\
182.7 \\
1.2 \\
26.8 \\
110.9 \\
14.6 \\
4.2 \\
130.4 \\
82.1 \\
19.3\end{array}$ & $\begin{array}{r}1.4 \\
74.5 \\
1.2 \\
13.1 \\
46.4 \\
11.2 \\
1.0 \\
78.6 \\
15.6 \\
--\end{array}$ & $\begin{array}{r}1.6 \\
49.9 \\
-- \\
8.6 \\
13.9 \\
1.1 \\
0.8 \\
27.2 \\
9.2 \\
--\end{array}$ & $\begin{array}{r}12.9 \\
58.3 \\
-- \\
5.1 \\
50.6 \\
2.3 \\
2.4 \\
24.6 \\
57.3 \\
--\end{array}$ & $\begin{array}{l}-- \\
-- \\
-- \\
-- \\
-- \\
-- \\
-- \\
-- \\
- \\
-3\end{array}$ \\
\hline All types & 588.1 & 243.0 & 112.3 & 213.5 & 19.3 \\
\hline \multicolumn{6}{|c|}{ SOUTHEASTERN UNIT } \\
\hline $\begin{array}{l}\text { Eastern redcedar-hardwood } \\
\text { 0ak-hickory } \\
\text { Post-blackjack oak } \\
\text { Upland plains hardwoods } \\
\text { Elm-ash-cottonwood } \\
\text { Cottonwood } \\
\text { Willow } \\
\text { Lowl and plains hardwoods } \\
\text { Upland elm-ash-locust } \\
\text { Nonstocked }\end{array}$ & $\begin{array}{r}11.6 \\
126.1 \\
29.7 \\
22.6 \\
107.5 \\
4.9 \\
-- \\
94.7 \\
24.3 \\
15.6 \\
\end{array}$ & $\begin{array}{r}1.3 \\
59.6 \\
7.3 \\
5.6 \\
52.3 \\
2.3 \\
-- \\
62.8 \\
1.2 \\
--\end{array}$ & $\begin{array}{r}1.2 \\
34.1 \\
17.6 \\
8.2 \\
17.0 \\
1.3 \\
-- \\
14.7 \\
.2 .5 \\
--\end{array}$ & $\begin{array}{r}9.1 \\
32.4 \\
4.8 \\
8.8 \\
38.2 \\
1.3 \\
-- \\
17.2 \\
20.6 \\
-- \\
\end{array}$ & $\begin{array}{l}- \\
-- \\
-- \\
-- \\
-- \\
-- \\
-- \\
-- \\
\end{array}$ \\
\hline All types & 437.0 & 192.4 & 96.6 & 132.4 & 15.6 \\
\hline \multicolumn{6}{|c|}{ WESTERN UNIT } \\
\hline $\begin{array}{l}\text { Eastern redcedar-hardwood } \\
\text { 0ak-hickory } \\
\text { Post-blackjack oak } \\
\text { Upland plains hardwoods } \\
\text { Elm-ash-cottonwood } \\
\text { Cottonwood } \\
\text { Willow } \\
\text { Lowland plains hardwoods } \\
\text { Upland elm-ash-locust } \\
\text { Nonstocked }\end{array}$ & $\begin{array}{r}7 .-8 \\
-- \\
-- \\
71.2 \\
48.6 \\
-- \\
40.8 \\
3.9 \\
10.5 \\
\end{array}$ & $\begin{array}{r}7.8 \\
-- \\
-- \\
46.4 \\
46.1 \\
-- \\
29.3 \\
-- \\
-- \\
\end{array}$ & $\begin{array}{r}-- \\
-- \\
-- \\
-- \\
16.1 \\
2.5 \\
-- \\
4.8 \\
2.1 \\
-- \\
\end{array}$ & $\begin{array}{r}-- \\
-- \\
-- \\
-- \\
8.7 \\
-- \\
-- \\
6.7 \\
1.8 \\
-- \\
\end{array}$ & $\begin{array}{l}-- \\
-- \\
-- \\
-- \\
-- \\
-- \\
-- \\
-- \\
10.5\end{array}$ \\
\hline All types & 182.8 & 129.6 & 25.5 & 17.2 & 10.5 \\
\hline
\end{tabular}


Table 20.--Area of commercial forest land by forest type, stand-size class, and site class, Kansas, 1981

(In thousand acres)

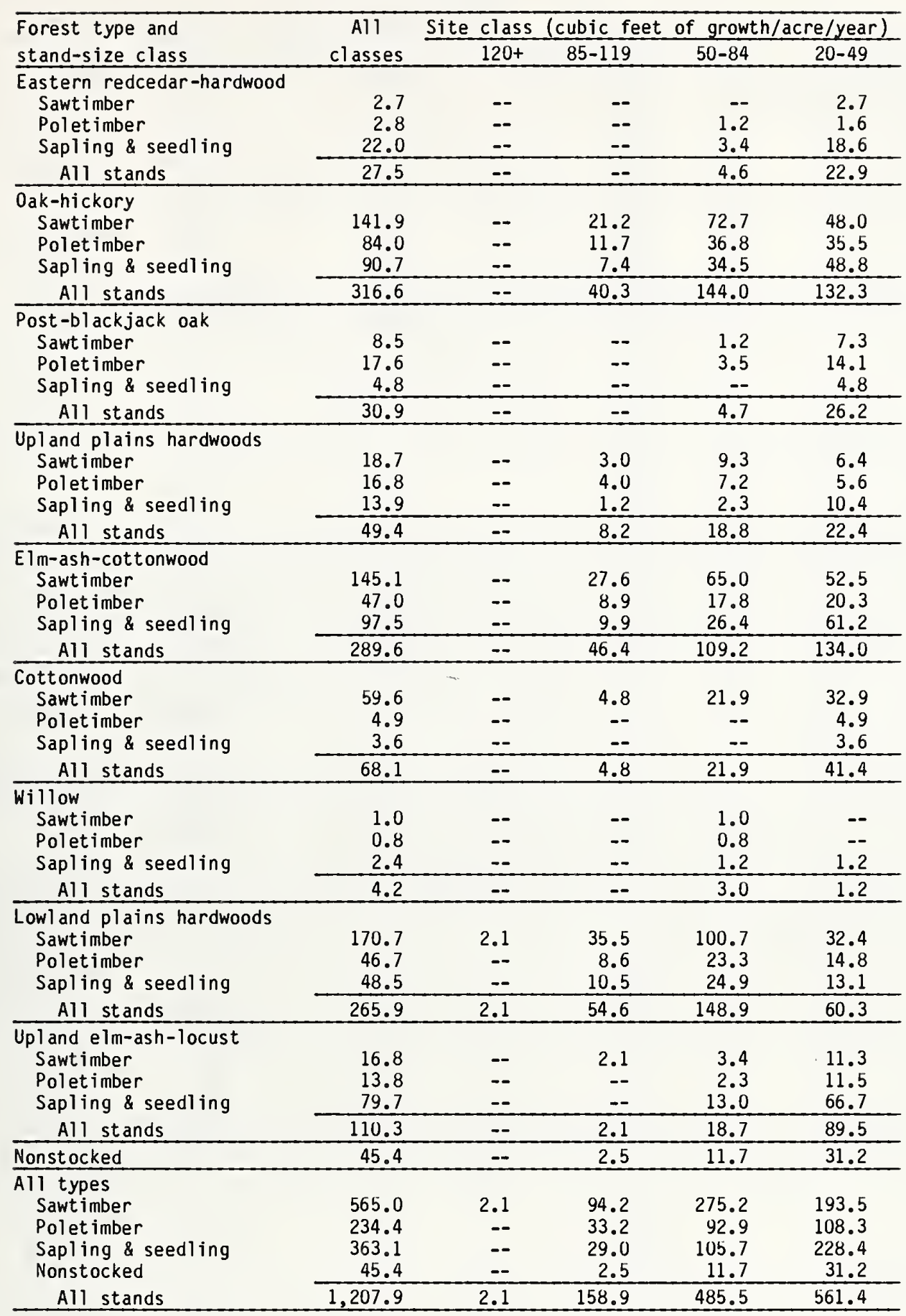


Table 21.--Area of commercial forest land by forest type, stand-size class, and stocking percent, Kansas, 1981

(In thousand acres)

\begin{tabular}{|c|c|c|c|c|c|c|}
\hline \multirow[b]{2}{*}{$\begin{array}{l}\text { Forest type and } \\
\text { stand-size class }\end{array}$} & \multirow[b]{2}{*}{$\begin{array}{c}\text { All } \\
\text { classes }\end{array}$} & \multicolumn{5}{|c|}{ Stocking percent of growing-stock trees } \\
\hline & & $\begin{array}{l}\text { Less than } \\
16.7\end{array}$ & $16.7-60$ & $61-100$ & $101-133$ & $134+$ \\
\hline \multirow{2}{*}{\multicolumn{7}{|c|}{$\begin{array}{l}\text { Eastern redcedar-hardwood } \\
\text { Sawtimber }\end{array}$}} \\
\hline & 2.7 & -- & -- & 2.7 & -- & -- \\
\hline Polet imber & 2.8 & -- & 1.6 & 1.2 & - & -- \\
\hline Sapling \& seedling & 22.0 & $=-$ & 14.4 & 6.4 & 1.2 & - \\
\hline & 27.5 & $=$ & 16.0 & 10.3 & 1.2 & -- \\
\hline \multicolumn{7}{|l|}{ 0ak-hickory } \\
\hline Sawtimber & 141.9 & -- & 48.4 & 77.2 & 16.3 & -- \\
\hline Poletimber & 84.0 & -- & 20.6 & 49.4 & 14.0 & -- \\
\hline Sapling \& seedling & 90.7 & - & 40.1 & 42.5 & 8.1 & $=$ \\
\hline All stands & 316.6 & -- & 109.1 & 169.1 & 38.4 & - \\
\hline \multicolumn{7}{|l|}{ Post-blackjack oak } \\
\hline Sawtimber & 8.5 & -- & 2.5 & 6.0 & -- & -- \\
\hline Poletimber & 17.6 & -- & 2.5 & 12.8 & 2.3 & -- \\
\hline Sapling \& seedling & 4.8 & - & 3.6 & -- & 1.2 & -- \\
\hline All stands & 30.9 & - & 8.6 & 18.8 & 3.5 & -- \\
\hline \multicolumn{7}{|l|}{ Upl and plains hardwoods } \\
\hline Sawtimber & 18.7 & -- & 11.0 & 7.7 & -- & -- \\
\hline Poletimber & 16.8 & -- & 11.3 & 5.5 & -- & -- \\
\hline Sapling \& seedling & 13.9 & - & 6.5 & 7.4 & -- & $=$ \\
\hline All stands & 49.4 & - & 28.8 & 20.6 & -- & -- \\
\hline \multicolumn{7}{|l|}{ Elm-ash-cottonwood } \\
\hline Sawtimber & 145.1 & -- & 62.8 & 67.4 & 14.9 & -- \\
\hline Poletimber & 47.0 & -- & 26.2 & 20.8 & - & -- \\
\hline Sapling \& seedling & 97.5 & $=$ & 59.9 & 35.1 & 2.5 & -- \\
\hline All stands & 289.6 & -- & 148.9 & 123.3 & 17.4 & $=$ \\
\hline \multicolumn{7}{|l|}{ Cottonwood } \\
\hline Sawtimber & 59.6 & -- & 19.4 & 23.9 & 16.3 & -- \\
\hline Poletimber & 4.9 & -- & 1.3 & 3.6 & -- & -- \\
\hline Sapling \& seedling & 3.6 & $=$ & 1.3 & 1.2 & 1.1 & -- \\
\hline All stands & 68.1 & -- & 22.0 & 28.7 & 17.4 & $\overline{--}$ \\
\hline \multicolumn{7}{|l|}{ Willow } \\
\hline Sawtimber & 1.0 & -- & 1.0 & -- & -- & -- \\
\hline Poletimber & 0.8 & -- & 0.8 & -- & -- & -- \\
\hline Sapling \& seedling & 2.4 & $=-$ & 1.2 & $=$ & 1.2 & -- \\
\hline All stands & 4.2 & $=$ & 3.0 & - & 1.2 & $=$ \\
\hline \multicolumn{7}{|l|}{ Lowl and plains hardwoods } \\
\hline Sawtimber & 170.7 & -- & 64.9 & 92.3 & 13.5 & -- \\
\hline Poletimber & 46.7 & -- & 21.7 & 25.0 & -- & -- \\
\hline Sapling \& seedling & 48.5 & $=$ & 27.0 & 21.5 & -- & - \\
\hline All stands & 265.9 & $=$ & 113.6 & 138.8 & 13.5 & -- \\
\hline \multicolumn{7}{|l|}{ Upland elm-ash-locust } \\
\hline Sawtimber & 16.8 & -- & 11.3 & 4.5 & 1.0 & -- \\
\hline Poletimber & 13.8 & -- & 9.1 & 4.7 & -- & -- \\
\hline Sapling \& seedling & 79.7 & $=$ & 52.9 & 25.4 & 1.4 & -- \\
\hline All stands & 110.3 & -- & 73.3 & 34.6 & 2.4 & -- \\
\hline Nonstocked & 45.4 & 45.4 & $=-$ & - & $=$ & -- \\
\hline \multicolumn{7}{|l|}{ All types } \\
\hline Sawtimber & 565.0 & -- & 221.3 & 281.7 & 62.0 & -- \\
\hline Poletimber & 234.4 & -- & 95.1 & 123.0 & 16.3 & -- \\
\hline Sapling \& seedling & 363.1 & -- & 206.9 & 139.5 & 16.7 & -- \\
\hline Nonstocked & 45.4 & 45.4 & $=$ & -- & $=$ & -- \\
\hline All stands & $1,207.9$ & 45.4 & 523.3 & 544.2 & 95.0 & -- \\
\hline
\end{tabular}


Table 22.--Area of commercial forest land by forest type, site-index class, and Forest Survey Unit, Kansas, 1981

(In thousand acres)

ALL UNITS

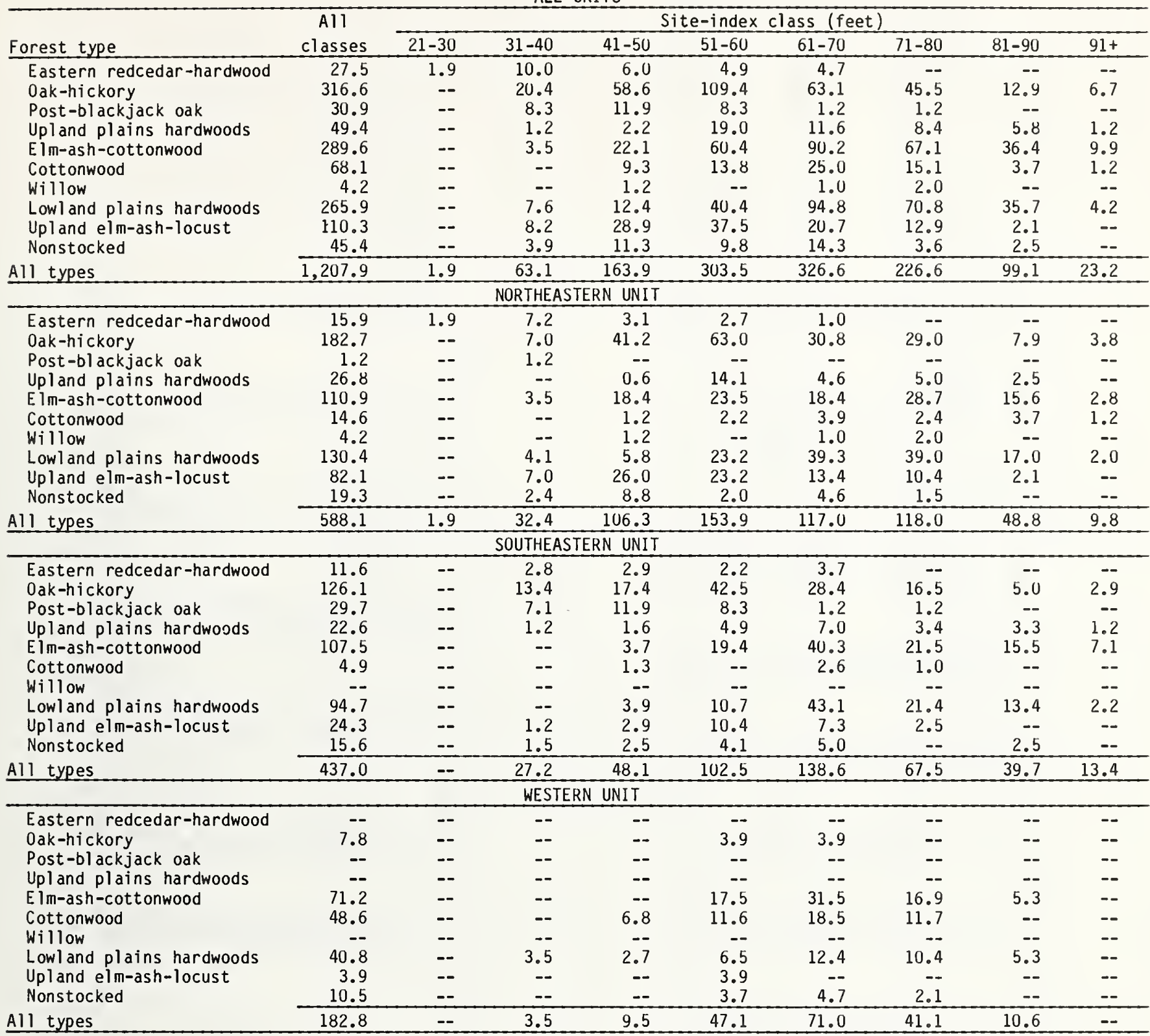



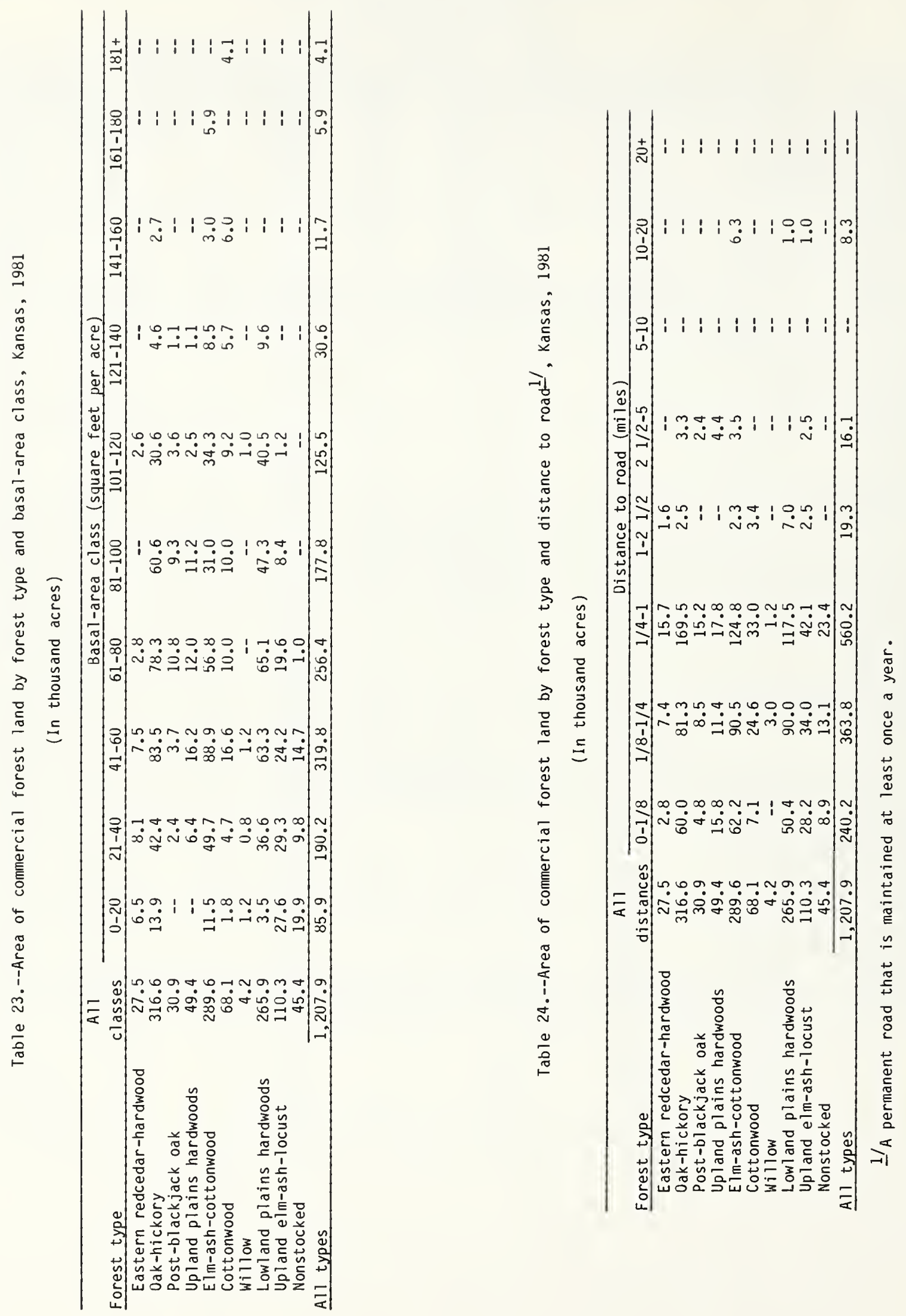

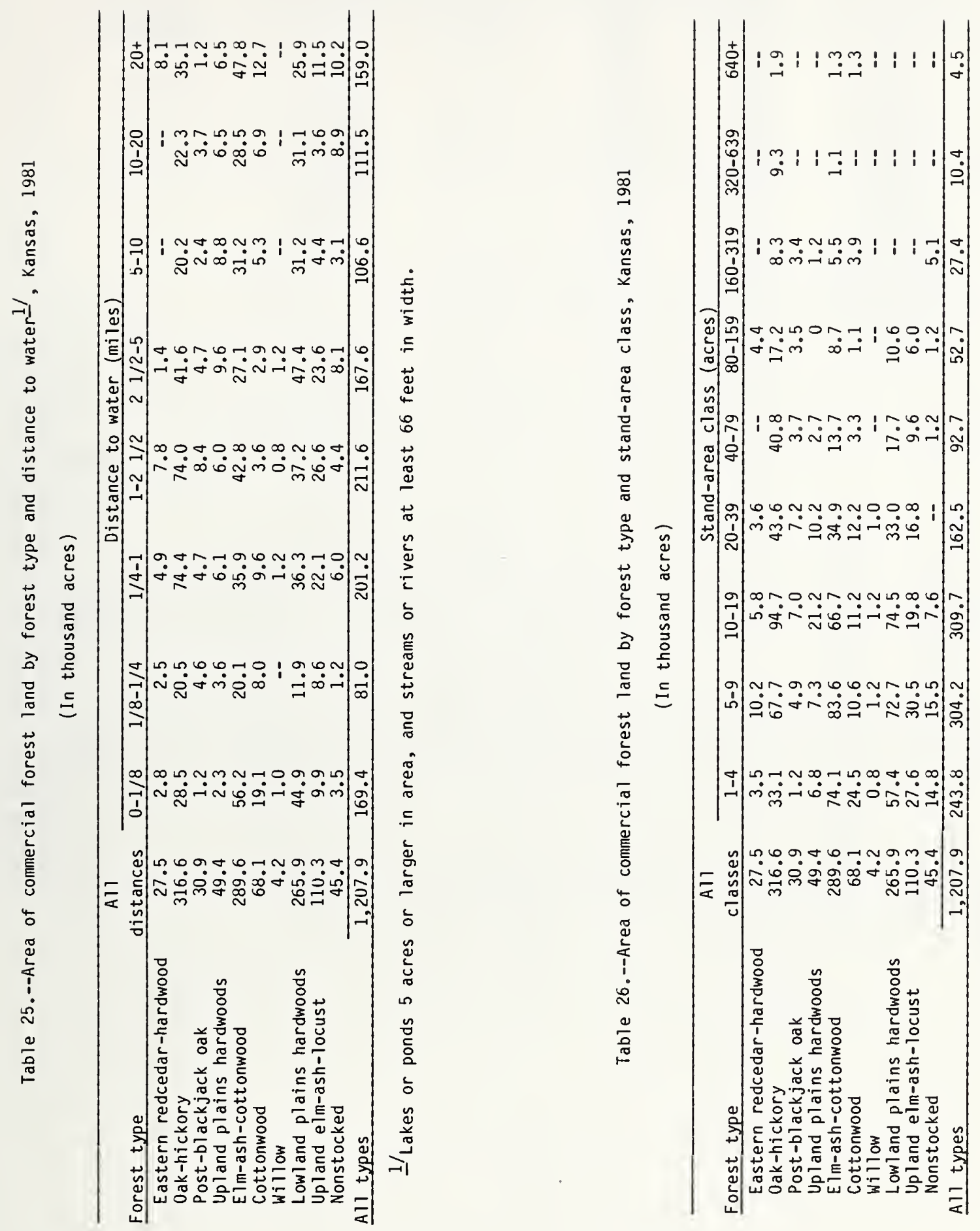
Table 27.--Area of commercial forest land by stocking class based on selected stand components, Kansas, 1981

(In thousand acres)

\begin{tabular}{|c|c|c|c|c|c|}
\hline \multirow[b]{2}{*}{$\begin{array}{c}\text { Stocking } \\
\text { percentage }\end{array}$} & \multirow{2}{*}{$\begin{array}{l}\text { All } \\
\text { live } \\
\text { trees }\end{array}$} & \multicolumn{4}{|c|}{ Stocking classified in terms of } \\
\hline & & $\begin{array}{c}\text { Growing-stock } \\
\text { trees }\end{array}$ & $\begin{array}{c}\text { Desirable } \\
\text { trees }\end{array}$ & $\begin{array}{c}\text { Acceptable } \\
\text { trees }\end{array}$ & $\begin{array}{l}\text { Rough and } \\
\text { rotten trees }\end{array}$ \\
\hline $0-10$ & 2.7 & 19.5 & $1,163.2$ & 19.5 & 175.3 \\
\hline $11-20$ & 2.5 & 43.9 & 36.2 & 46.1 & 271.3 \\
\hline $21-30$ & 12.4 & 71.8 & 5.0 & 79.9 & 281.0 \\
\hline $31-40$ & 22.1 & 143.6 & 2.2 & 148.4 & 217.7 \\
\hline $41-50$ & 51.5 & 134.9 & -- & 144.3 & 133.5 \\
\hline $51-60$ & 81.8 & 155.1 & 1.3 & 155.6 & 61.8 \\
\hline $61-70$ & 95.6 & 166.7 & -- & 176.1 & 43.7 \\
\hline $71-80$ & 119.0 & 156.0 & -- & 150.2 & 20.3 \\
\hline $81-90$ & 176.5 & 129.9 & -- & 124.2 & 2.1 \\
\hline $91-100$ & 187.4 & 91.5 & -- & 87.5 & 1.2 \\
\hline $101-110$ & 154.8 & 52.5 & -- & 38.6 & -- \\
\hline $111-120$ & 149.3 & 25.8 & -- & 23.1 & -- \\
\hline $121-130$ & 82.4 & 16.7 & -- & 14.4 & -- \\
\hline $131-140$ & 48.6 & -- & -- & -- & -- \\
\hline $141-150$ & 19.5 & -- & -- & -- & -- \\
\hline $151-160$ & 1.8 & -- & -- & -- & -- \\
\hline $161+$ & -- & -- & -- & -- & -- \\
\hline Total & $1,207.9$ & $1,207.9$ & $1,207.9$ & $1,207.9$ & $1,207.9$ \\
\hline
\end{tabular}


Table 28.--Area of commercial forest land by forest type, physiographic class, and ownership class, Kansas, 1981

(In thousand acres)

\begin{tabular}{|c|c|c|c|c|c|c|c|c|}
\hline \multirow[b]{2}{*}{$\begin{array}{l}\text { Forest type and } \\
\text { physiographic class }\end{array}$} & \multirow[b]{2}{*}{$\begin{array}{c}\text { All } \\
\text { classes } \\
\end{array}$} & \multicolumn{7}{|c|}{ Ownership class } \\
\hline & & $\begin{array}{c}\text { National } \\
\text { Forest } \\
\end{array}$ & $\begin{array}{l}\text { Misc. } \\
\text { federal }\end{array}$ & Indian & State & $\begin{array}{l}\text { County and } \\
\text { municipal }\end{array}$ & Farmer & $\begin{array}{l}\text { Misc. } \\
\text { private }\end{array}$ \\
\hline \multicolumn{9}{|c|}{ Eastern redcedar-hardwood } \\
\hline Hydric & -- & -- & -- & -- & -- & -- & -- & -- \\
\hline Hydromesic & -- & -- & -- & -- & -- & -- & -- & -- \\
\hline Mesic & 2.4 & -- & -- & -- & -- & -- & 2.4 & -- \\
\hline Xeromesic & 25.1 & -- & 1.6 & -- & - & -- & 16.3 & 7.2 \\
\hline Xeric & -- & $=$ & -- & - & $=$ & - & -- & $\because-$ \\
\hline All classes & 27.5 & $=-$ & 1.6 & -- & -- & -- & 18.7 & 7.2 \\
\hline \multicolumn{9}{|l|}{ 0ak-hickory } \\
\hline Hydric & 2.6 & -- & -- & -- & -- & -- & 2.6 & -- \\
\hline Hyd romes ic & 7.6 & -- & -- & -- & -- & -- & 4.2 & 3.4 \\
\hline Mesic & 132.7 & -- & 0.9 & 1.2 & 2.6 & -- & 76.7 & 51.3 \\
\hline Xeromesic & 155.5 & -- & 5.9 & -- & -- & -- & 88.5 & 61.1 \\
\hline Xeric & 18.2 & -- & -- & -- & -- & -- & 12.4 & 5.8 \\
\hline All classes & 316.6 & -- & 6.8 & 1.2 & 2.6 & -- & 184.4 & 121.6 \\
\hline \multicolumn{9}{|l|}{ Post-blackjack oak } \\
\hline Hydric & -- & -- & -- & -- & -- & -- & -- & -- \\
\hline Hydromesic & 1.2 & -- & -- & -- & -- & -- & 1.2 & -- \\
\hline Mesic & 9.8 & -- & -- & -- & -- & -- & 8.5 & 1.3 \\
\hline Xeromesic & 17.6 & -- & 1.2 & -- & -- & -- & 11.7 & 4.7 \\
\hline Xeric & 2.3 & $=-$ & -- & $=$ & $=$ & $=$ & 1.1 & 1.2 \\
\hline All classes & 30.9 & -- & 1.2 & -- & - & - & 22.5 & 7.2 \\
\hline \multicolumn{9}{|c|}{ Upland plains hardwoods } \\
\hline Hydric & -- & -- & -- & -- & -- & -- & -- & -- \\
\hline Hydromesic & -- & -- & -- & -- & -- & -- & -- & -- \\
\hline Mesic & 1.2 & -- & -- & -- & -- & -- & 1.2 & -- \\
\hline Xeromesic & 46.5 & -- & 2.5 & -- & -- & 1.1 & 23.9 & 19.0 \\
\hline Xeric & 1.7 & -- & -- & -- & -- & -- & 1.7 & -- \\
\hline All classes & 49.4 & -- & 2.5 & -- & -- & 1.1 & 26.8 & 19.0 \\
\hline \multicolumn{9}{|l|}{ Elm-ash-cottonwood } \\
\hline Hydric & 9.0 & -- & -- & -- & -- & -- & 2.3 & 6.7 \\
\hline Hydromes ic & 77.1 & -- & 3.3 & -- & 1.0 & -- & 49.6 & 23.2 \\
\hline Mesic & 203.5 & -- & 5.3 & 1.6 & -- & 1.2 & 130.3 & 65.1 \\
\hline Xeromesic & -- & -- & -- & -- & -- & -- & -- & -- \\
\hline Xeric & - & -- & -- & -- & -- & -- & -- & - \\
\hline All classes & 289.6 & -- & 8.6 & 1.6 & 1.0 & 1.2 & 182.2 & 95.0 \\
\hline \multicolumn{9}{|l|}{ Cottonwood } \\
\hline Hydric & 3.9 & -- & -- & -- & -- & -- & -- & 3.9 \\
\hline Hydromesic & 20.2 & -- & 3.0 & -- & 2.5 & -- & 6.9 & 7.8 \\
\hline Mesic & 29.9 & -- & -- & -- & -- & -- & 16.3 & 13.6 \\
\hline Xeromesic & 6.9 & -- & -- & -- & -- & -- & 4.8 & 2.1 \\
\hline Xeric & 7.2 & -- & -- & -- & - & -- & 7.2 & -- \\
\hline All classes & 68.1 & -- & 3.0 & -- & 2.5 & -- & 35.2 & 27.4 \\
\hline
\end{tabular}




\begin{tabular}{|c|c|c|c|c|c|c|c|c|}
\hline \multirow[b]{2}{*}{$\begin{array}{l}\text { Forest type and } \\
\text { physiographic class }\end{array}$} & \multirow[b]{2}{*}{$\begin{array}{c}\text { All } \\
\text { classes }\end{array}$} & \multicolumn{7}{|c|}{ Ownership class } \\
\hline & & $\begin{array}{c}\text { National } \\
\text { Forest }\end{array}$ & $\begin{array}{c}\text { Misc. } \\
\text { federal }\end{array}$ & Indian & State & $\begin{array}{l}\text { County and } \\
\text { municipal }\end{array}$ & Farmer & $\begin{array}{l}\text { Misc. } \\
\text { private }\end{array}$ \\
\hline \multicolumn{9}{|l|}{ Willow } \\
\hline Hydric & -- & - & -- & - & -- & -- & -- & -- \\
\hline Hydromesic & 3.4 & -- & -- & -- & -- & -- & 1.0 & 2.4 \\
\hline Mesic & -- & -- & -- & -- & -- & -- & -- & -- \\
\hline Xeromesic & 0.8 & -- & -- & -- & -- & -- & -- & 0.8 \\
\hline Xeric & -- & -- & - & -- & -- & -- & - & -- \\
\hline All classes & 4.2 & $=$ & $=$ & - & -- & - & 1.0 & 3.2 \\
\hline \multicolumn{9}{|c|}{ Lowland plains hardwoods } \\
\hline Hydric & 2.5 & -- & - & -- & - & -- & 2.5 & -- \\
\hline Hydromesic & 52.3 & -- & 2.7 & -- & -- & -- & 31.6 & 18.0 \\
\hline Mesic & 211.1 & -- & 4.4 & -- & -- & -- & 152.5 & 54.2 \\
\hline Xeromesic & -- & -- & -- & -- & -- & -- & -- & -- \\
\hline Xeric & -- & -- & -- & -- & -- & $=-$ & -- & - \\
\hline All classes & 265.9 & -- & 7.1 & -- & -- & - & 186.6 & 72.2 \\
\hline \multicolumn{9}{|l|}{ Upland elm-ash-locust } \\
\hline Hydric & -- & -- & -- & -- & -- & -- & -- & -- \\
\hline Hydromesic & -- & -- & -- & -- & -- & -- & -- & -- \\
\hline Mesic & -- & -- & -- & -- & -- & -- & - & -- \\
\hline Xeromesic & 100.5 & -- & 5.8 & 1.2 & -- & -- & 54.7 & 38.8 \\
\hline Xeric & 9.8 & -- & - & -- & -- & -- & 8.8 & 1.0 \\
\hline All classes & 110.3 & - & 5.8 & 1.2 & -- & - & 63.5 & 39.8 \\
\hline \multicolumn{9}{|l|}{ Nonstocked } \\
\hline Hydric & 9.1 & -- & -- & -- & 1.4 & -- & - & 7.7 \\
\hline Hydromesic & 3.0 & -- & -- & -- & -- & -- & 3.0 & -- \\
\hline Mesic & 11.5 & -- & -- & -- & -- & -- & 7.7 & 3.8 \\
\hline Xeromesic & 19.7 & -- & -- & -- & -- & -- & 15.8 & 3.9 \\
\hline Xeric & 2.1 & -- & -- & -- & -- & -- & 2.1 & -- \\
\hline All classes & 45.4 & - & - & -- & 1.4 & -- & 28.6 & 15.4 \\
\hline \multicolumn{9}{|l|}{ Al1 types } \\
\hline Hydric & 27.1 & -- & $\rightarrow$ & -- & 1.4 & - & 7.4 & 18.3 \\
\hline Hydromesic & 164.8 & - & 9.0 & - & 3.5 & -- & 97.5 & 54.8 \\
\hline Mesic & 602.1 & -- & 10.6 & 2.8 & 2.6 & 1.2 & 395.6 & 189.3 \\
\hline Xeromesic & 372.6 & -- & 17.0 & 1.2 & -- & 1.1 & 215.7 & 137.6 \\
\hline Xeric & 41.3 & - & -- & - & -- & -- & 33.3 & 8.0 \\
\hline All classes & $1,207.9$ & - & 36.6 & 4.0 & 7.5 & 2.3 & 749.5 & 408.0 \\
\hline
\end{tabular}

Table 29.--Area of noncommercial forest land by ownership class, Kansas, 1981

(In thousand acres)

\begin{tabular}{lrrr}
\hline Ownership class & Total & Unproductive & $\begin{array}{c}\text { Productive- } \\
\text { reserved }\end{array}$ \\
\hline National Forest & -- & -- & -- \\
Miscellaneous federal & 13.8 & -- & 13.8 \\
Indian & -- & -- & -- \\
State & 2.8 & -- & 2.8 \\
County and municipal & 4.8 & -- & 4.8 \\
Farmer & 89.1 & 89.1 & -- \\
Miscellaneous private & 40.3 & 39.3 & 1.0 \\
All owners & 150.8 & 128.4 & 22.4 \\
\hline
\end{tabular}


Table 30.--Area of noncommercial forest land by forest type and Forest Survey Unit, Kansas, 1981

(In thousand acres)

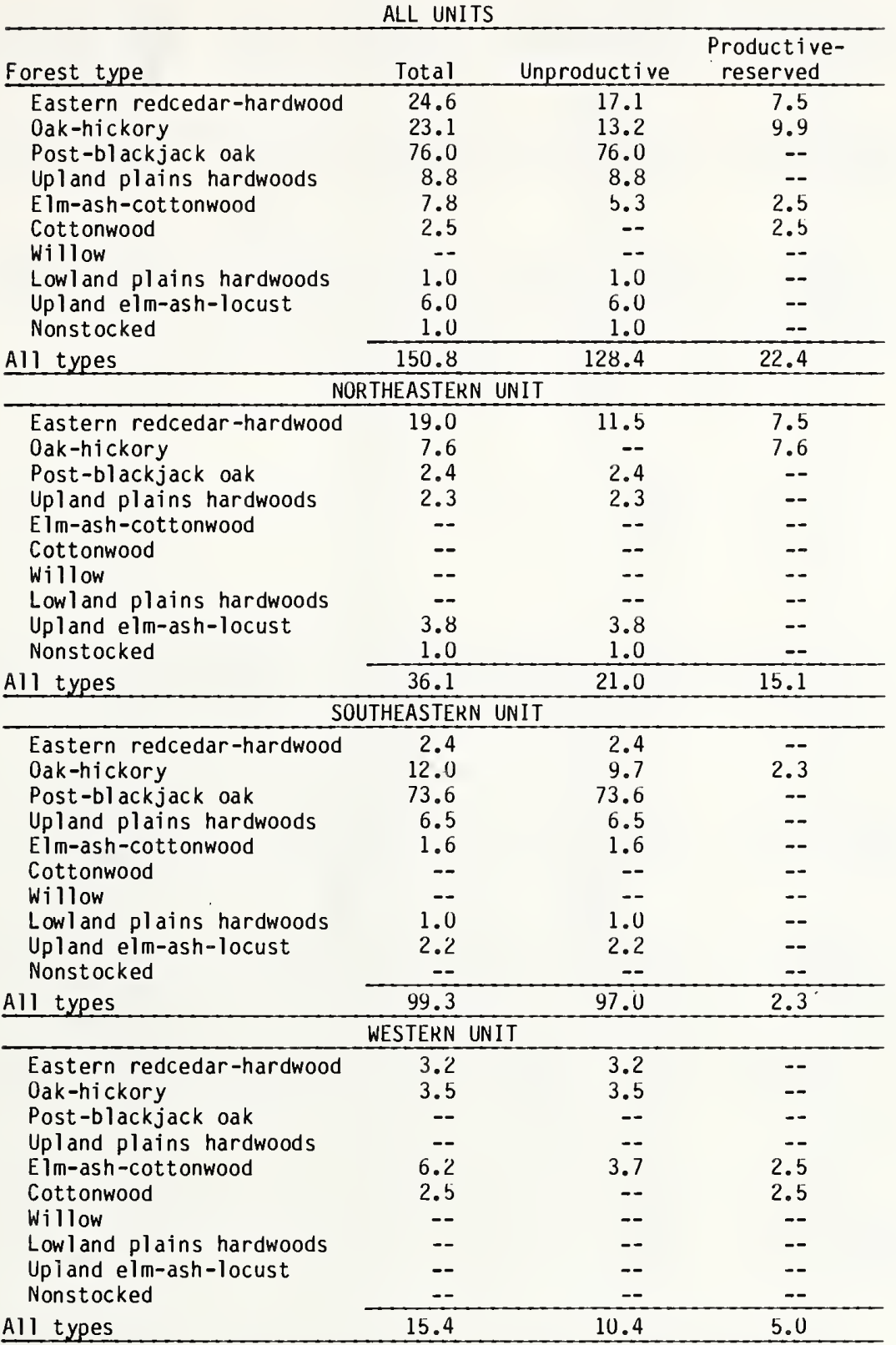




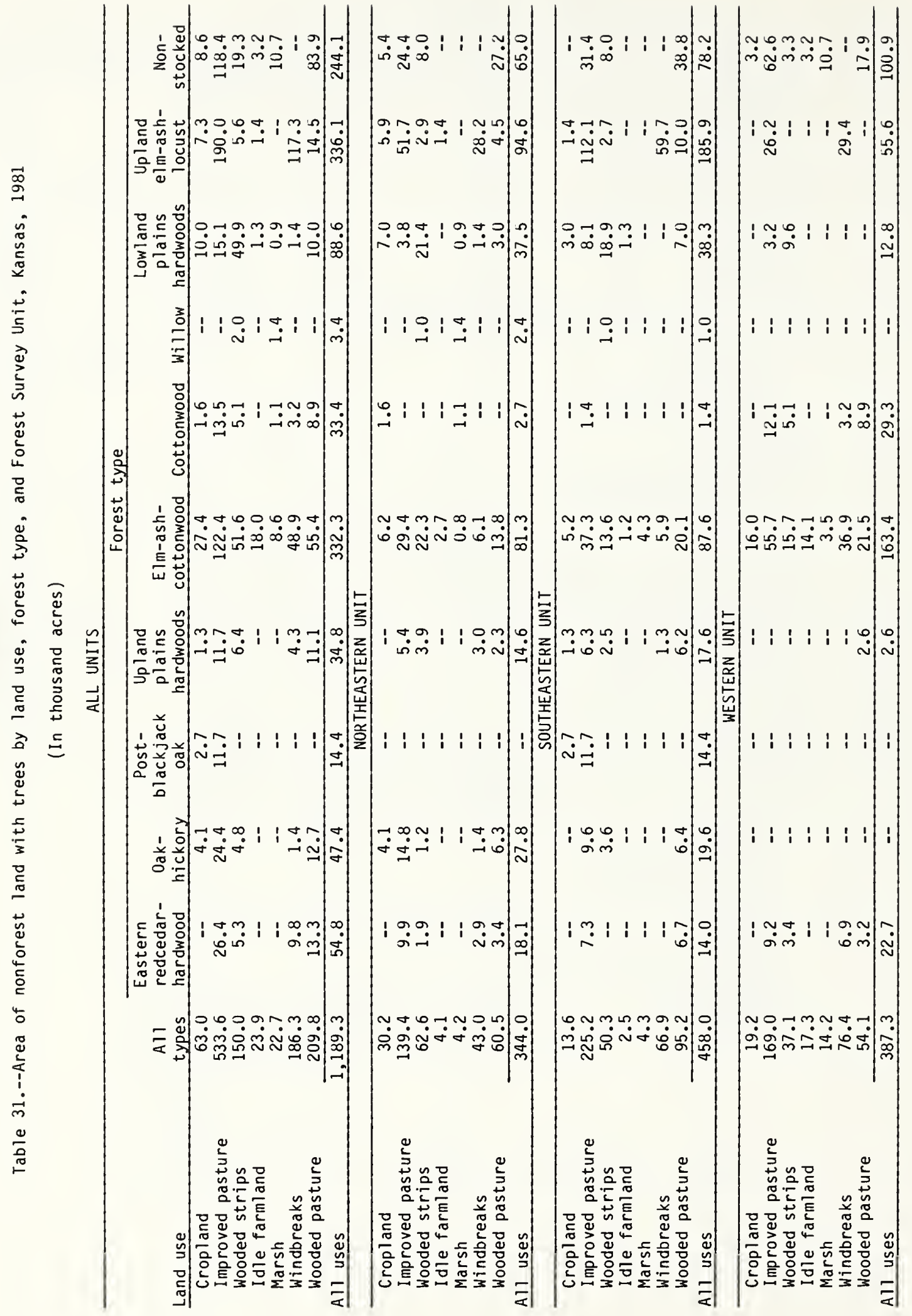


Table 32.--Area of nonforest land with trees by forest type and stand-size class, Kansas, 1981

(In thousand acres)

\begin{tabular}{|c|c|c|c|c|c|}
\hline \multirow[b]{2}{*}{ Forest type } & \multirow[b]{2}{*}{$\begin{array}{c}\text { All } \\
\text { stands }\end{array}$} & \multicolumn{4}{|c|}{ Stand-size class } \\
\hline & & $\begin{array}{c}\text { Sawt imber } \\
\text { st ands }\end{array}$ & $\begin{array}{l}\text { Polet imber } \\
\text { stands }\end{array}$ & $\begin{array}{l}\text { Sapling and } \\
\text { seedling stands }\end{array}$ & $\begin{array}{c}\text { Nonstocked } \\
\text { areas }\end{array}$ \\
\hline Eastern redcedar-hardwood & 54.8 & -- & 16.8 & 38.0 & -- \\
\hline Oak-hickory & 47.4 & 14.5 & 14.7 & 18.2 & -- \\
\hline Post-blackjack oak & 14.4 & 1.3 & 6.2 & 6.9 & -- \\
\hline Upland plains hardwoods & 34.8 & 8.8 & 11.0 & 15.0 & -- \\
\hline Elm-ash-cottonwood & 332.3 & 51.8 & 144.3 & 136.2 & -- \\
\hline Cottonwood & 33.4 & 23.8 & 9.6 & -- & -- \\
\hline Willow & 3.4 & - & 2.4 & 1.0 & -- \\
\hline Lowland plains hardwoods & 88.6 & 18.7 & 40.4 & 29.5 & -. \\
\hline Upland elm-ash-locust & 336.1 & 24.6 & 157.4 & 154.1 & -- \\
\hline Nonstocked & 244.1 & -- & - & - & 244.1 \\
\hline All types & $1,189.3$ & 143.5 & 402.8 & 398.9 & 244.1 \\
\hline
\end{tabular}


Table 33.--Area of windbreaks by forest type, stand-size class, and Forest Survey Unit, Kansas, 1981

(In thousand acres)

ALL UNITS

\begin{tabular}{|c|c|c|c|c|c|}
\hline \multirow[b]{2}{*}{ Forest type } & \multirow[b]{2}{*}{$\begin{array}{c}\text { All } \\
\text { stands }\end{array}$} & \multicolumn{4}{|c|}{ Stand-size class } \\
\hline & & $\begin{array}{c}\text { Sawtimber } \\
\text { stands }\end{array}$ & $\begin{array}{c}\begin{array}{c}\text { Poletimber } \\
\text { stands }\end{array} \\
\end{array}$ & $\begin{array}{l}\text { Sapling and } \\
\text { seedling stands }\end{array}$ & $\begin{array}{c}\text { Nonstocked } \\
\text { areas }\end{array}$ \\
\hline Eastern redcedar-hardwood & 9.8 & -- & 6.9 & 2.9 & -- \\
\hline 0ak-hickory & 1.4 & -- & 1.4 & -- & -- \\
\hline Post-blackjack oak & -- & -- & -- & -- & -- \\
\hline Upland plains hardwoods & 4.3 & 1.6 & 2.7 & -- & -- \\
\hline Elm-ash-cottonwood & 48.8 & 3.3 & 39.1 & 6.4 & -- \\
\hline Cottonwood & 3.2 & -- & 3.2 & -- & -- \\
\hline Willow & -- & -- & -- & -- & -- \\
\hline Lowland plains hardwoods & 1.4 & -- & 1.4 & -- & -- \\
\hline Upland elm-ash-locust & 117.4 & 11.4 & 87.0 & 19.0 & -- \\
\hline Nonstocked & -- & -- & - & -- & -- \\
\hline Al1 types & 186.3 & 16.3 & 141.7 & 28.3 & -- \\
\hline \multicolumn{6}{|c|}{ NORTHEASTERN UNIT } \\
\hline Eastern redcedar-hardwood & 2.9 & -- & -- & 2.9 & -- \\
\hline 0ak-hickory & 1.4 & -- & 1.4 & -- & -- \\
\hline Post-blackjack oak & -- & -- & -- & -- & -- \\
\hline Upland plains hardwoods & 3.0 & 1.6 & 1.4 & -- & -- \\
\hline Elm-ash-cottonwood & 6.0 & -- & 4.5 & 1.5 & -- \\
\hline Cottonwood & -- & -- & -- & -- & -- \\
\hline Willow & -- & -- & -- & -- & -- \\
\hline Lowland plains hardwoods & 1.4 & -- & 1.4 & -- & -- \\
\hline Upland elm-ash-locust & 28.3 & 2.8 & 19.8 & 5.7 & -- \\
\hline Nonstocked & -- & -- & -- & -- & $\because-$ \\
\hline All types & 43.0 & 4.4 & 28.5 & 10.1 & $\because-$ \\
\hline \multicolumn{6}{|c|}{ SOUTHEASTERN UNIT } \\
\hline Eastern redcedar-hardwood & -- & -- & -- & -- & -- \\
\hline Oak-hickory & -- & -- & -- & -- & -- \\
\hline Post-blackjack oak & -- & -- & -- & -- & -- \\
\hline Upland plains hardwoods & 1.3 & -- & 1.3 & -- & -- \\
\hline Elm-ash-cottonwood & 5.9 & -- & 4.2 & 1.7 & -- \\
\hline Cottonwood & -- & -- & -- & -- & -- \\
\hline Willow & -- & -- & -- & -- & -- \\
\hline Lowl and plains hardwoods & -- & -- & -- & -- & -- \\
\hline Upland elm-ash-locust & 59.7 & 1.3 & 48.3 & 10.1 & -- \\
\hline Nonstocked & $\ldots$ & -- & -- & -- & -- \\
\hline All types & 66.9 & 1.3 & 53.8 & 11.8 & -- \\
\hline \multicolumn{6}{|c|}{ WESTERN UNIT } \\
\hline Eastern redcedar-hardwood & 6.9 & -- & 6.9 & -- & -- \\
\hline Oak-hickory & -- & -- & -- & -- & -- \\
\hline Post-blackjack oak & -- & -- & -- & -- & -- \\
\hline Upland plains hardwoods & - & -- & - & -- & -- \\
\hline Elm-ash-cott onwood & 36.9 & 3.3 & 30.4 & 3.2 & -- \\
\hline Cottonwood & 3.2 & -- & 3.2 & -- & -- \\
\hline Willow & -- & -- & -- & -- & -- \\
\hline Lowland plains hardwoods & -- & -- & -- & -- & -- \\
\hline Upland elm-ash-locust & 29.4 & 7.3 & 18.9 & 3.2 & -- \\
\hline Nonst ocked & $=-$ & -- & -- & $\therefore$ & -- \\
\hline A11 types & 76.4 & 10.6 & 59.4 & 6.4 & -- \\
\hline
\end{tabular}


Table 34.--Area of wooded strips by forest type, stand-size class, and ownership class, Kansas, 1981

(In thousand acres)

\begin{tabular}{|c|c|c|c|c|c|c|c|c|}
\hline \multirow[b]{2}{*}{$\begin{array}{l}\text { Forest type and } \\
\text { stand-size class }\end{array}$} & \multirow[b]{2}{*}{$\begin{array}{c}\text { All } \\
\text { classes } \\
\end{array}$} & \multicolumn{7}{|c|}{ Ownership class } \\
\hline & & $\begin{array}{c}\text { National } \\
\text { Forest } \\
\end{array}$ & $\begin{array}{l}\text { Misc. } \\
\text { federal }\end{array}$ & Indian & State & $\begin{array}{c}\text { County and } \\
\text { municipal }\end{array}$ & Farmer & $\begin{array}{l}\text { Misc. } \\
\text { private }\end{array}$ \\
\hline $\begin{array}{l}\text { Eastern redcedar-hardwood } \\
\text { Sawtimber } \\
\text { Polet imber } \\
\text { Sapling \& seedling }\end{array}$ & $\begin{array}{l}-- \\
3.4 \\
1.9 \\
5.3\end{array}$ & $\begin{array}{l}-- \\
-- \\
--\end{array}$ & $\begin{array}{l}-- \\
-- \\
-- \\
--\end{array}$ & $\begin{array}{l}-- \\
-- \\
-- \\
--\end{array}$ & $\begin{array}{l}-- \\
-- \\
-- \\
--\end{array}$ & $\begin{array}{l}-- \\
-- \\
-- \\
--\end{array}$ & $\begin{array}{l}-- \\
3.4 \\
1.9 \\
5.3\end{array}$ & $\begin{array}{l}-- \\
-- \\
--\end{array}$ \\
\hline $\begin{array}{l}\text { All stands } \\
\text { Oak-hickory } \\
\text { Sawtimber } \\
\text { Poletimber } \\
\text { Sapling \& seedling }\end{array}$ & $\begin{array}{l}-- \\
2.4 \\
2.7\end{array}$ & $\begin{array}{l}-- \\
-- \\
--\end{array}$ & $\begin{array}{l}-- \\
-- \\
--\end{array}$ & $\begin{array}{l}-- \\
-- \\
--\end{array}$ & $\begin{array}{l}-- \\
-- \\
--\end{array}$ & $\begin{array}{l}-- \\
-- \\
--\end{array}$ & $\begin{array}{r}-- \\
2.4 \\
2.7\end{array}$ & $\begin{array}{l}-- \\
-- \\
--\end{array}$ \\
\hline A11 stands & 5.1 & -- & -- & - & $\ldots$ & -- & 5.1 & -- \\
\hline $\begin{array}{l}\text { Post-blackjack oak } \\
\text { Sawtimber } \\
\text { Poletimber } \\
\text { Sapling \& seedling }\end{array}$ & $\begin{array}{l}-- \\
-- \\
-- \\
\end{array}$ & $\begin{array}{l}-- \\
-- \\
-- \\
\end{array}$ & $\begin{array}{l}-- \\
-- \\
--\end{array}$ & $\begin{array}{l}-- \\
-- \\
--\end{array}$ & $\begin{array}{l}-- \\
-- \\
--\end{array}$ & $\begin{array}{l}-- \\
-- \\
-- \\
\end{array}$ & $\begin{array}{l}-- \\
-- \\
-- \\
\end{array}$ & $\begin{array}{l}-- \\
-- \\
-- \\
\end{array}$ \\
\hline A11 stands & $\because$ & -- & $=-$ & -- & -- & $=$ & $=$ & $=$ \\
\hline $\begin{array}{l}\text { Upland plains hardwoods } \\
\text { Sawtimber } \\
\text { Poletimber } \\
\text { Sapling \& seedling }\end{array}$ & $\begin{array}{r}-- \\
2.8 \\
3.6 \\
\end{array}$ & $\begin{array}{l}-- \\
-- \\
-\end{array}$ & $\begin{array}{l}-- \\
-- \\
-- \\
\end{array}$ & $\begin{array}{l}-- \\
-- \\
-\end{array}$ & $\begin{array}{l}-- \\
-- \\
--\end{array}$ & $\begin{array}{l}-- \\
-- \\
--\end{array}$ & $\begin{array}{r}-- \\
2.8 \\
2.0 \\
\end{array}$ & $\begin{array}{r}-- \\
-- \\
1.6 \\
\end{array}$ \\
\hline All stands & 6.4 & -- & -- & -- & -- & -- & 4.8 & 1.6 \\
\hline $\begin{array}{l}\text { Elm-ash-cottonwood } \\
\text { Sawtimber } \\
\text { Poletimber } \\
\text { Sapling \& seedling }\end{array}$ & $\begin{array}{r}4.6 \\
24.1 \\
23.1 \\
\end{array}$ & $\begin{array}{l}-- \\
-- \\
-- \\
\end{array}$ & $\begin{array}{r}1.3 \\
3.3 \\
-- \\
\end{array}$ & $\begin{array}{l}-- \\
-- \\
- \\
\end{array}$ & $\begin{array}{l}-- \\
-- \\
-\end{array}$ & $\begin{array}{l}-- \\
-- \\
-\end{array}$ & $\begin{array}{r}3.3 \\
17.8 \\
17.4 \\
\end{array}$ & $\begin{array}{r}-- \\
3.0 \\
5.7 \\
\end{array}$ \\
\hline Al1 stands & 51.8 & - & 4.6 & -- & -- & - & 38.5 & 8.7 \\
\hline $\begin{array}{l}\text { Cottonwood } \\
\text { Sawtimber } \\
\text { Poletimber } \\
\text { Sapling \& seedling }\end{array}$ & $\begin{array}{r}2.5 \\
2.6 \\
-- \\
\end{array}$ & $\begin{array}{l}-- \\
-- \\
--\end{array}$ & $\begin{array}{l}-- \\
-- \\
--\end{array}$ & $\begin{array}{l}-- \\
-- \\
--\end{array}$ & $\begin{array}{l}-- \\
-- \\
-\end{array}$ & $\begin{array}{l}-- \\
-- \\
-- \\
\end{array}$ & $\begin{array}{r}2.5 \\
-- \\
-- \\
\end{array}$ & $\begin{array}{r}-- \\
2.6 \\
--\end{array}$ \\
\hline A11 stands & 5.1 & -- & -- & -- & -- & -- & 2.5 & 2.6 \\
\hline $\begin{array}{l}\text { Willow } \\
\text { Sawtimber } \\
\text { Poletimber } \\
\text { Sapling \& seedling }\end{array}$ & $\begin{array}{l}-- \\
1.0 \\
1.0 \\
\end{array}$ & $\begin{array}{l}-- \\
-- \\
-- \\
\end{array}$ & $\begin{array}{l}-- \\
-- \\
--\end{array}$ & $\begin{array}{l}-- \\
-- \\
--\end{array}$ & $\begin{array}{l}-- \\
-- \\
-- \\
\end{array}$ & $\begin{array}{l}-- \\
-- \\
-- \\
\end{array}$ & $\begin{array}{l}-- \\
1.0 \\
1.0 \\
\end{array}$ & $\begin{array}{l}-- \\
-- \\
-- \\
\end{array}$ \\
\hline All stands & 2.0 & -- & -- & $=-$ & -- & -- & 2.0 & $=$ \\
\hline $\begin{array}{l}\text { Lowland plains hardwoods } \\
\text { Sawtimber } \\
\text { Poletimber } \\
\text { Sapling \& seedling }\end{array}$ & $\begin{array}{r}6.8 \\
13.5 \\
14.9 \\
\end{array}$ & $\begin{array}{l}-- \\
-- \\
--\end{array}$ & $\begin{array}{l}-- \\
-- \\
-\end{array}$ & $\begin{array}{l}-- \\
-- \\
--\end{array}$ & $\begin{array}{l}-- \\
-- \\
-\end{array}$ & $\begin{array}{l}-- \\
-- \\
-- \\
\end{array}$ & $\begin{array}{r}3.7 \\
12.1 \\
13.9 \\
\end{array}$ & $\begin{array}{l}3.1 \\
1.4 \\
1.0 \\
\end{array}$ \\
\hline All stands & 35.2 & -- & -- & -- & -- & -- & 29.7 & 5.5 \\
\hline $\begin{array}{l}\text { Upland elm-ash-locust } \\
\text { Sawt imber } \\
\text { Poletimber } \\
\text { Sapling \& seedling }\end{array}$ & $\begin{array}{r}1.4 \\
8.1 \\
10.4 \\
\end{array}$ & $\begin{array}{l}-- \\
-- \\
--\end{array}$ & $\begin{array}{r}-- \\
-- \\
1.2\end{array}$ & $\begin{array}{l}-- \\
-- \\
--\end{array}$ & $\begin{array}{l}-- \\
-- \\
--\end{array}$ & $\begin{array}{l}-- \\
-- \\
--\end{array}$ & $\begin{array}{r}-- \\
6.6 \\
4.0\end{array}$ & $\begin{array}{l}1.4 \\
1.5 \\
5.2\end{array}$ \\
\hline All stands & 19.9 & -- & 1.2 & -- & -- & -- & 10.6 & 8.1 \\
\hline Nonstocked & 19.2 & -- & -- & -- & -- & -- & 16.1 & 3.1 \\
\hline $\begin{array}{l}\text { A1l types } \\
\text { Sawtimber } \\
\text { Poletimber } \\
\text { Sapling \& seedling } \\
\text { Nonstocked }\end{array}$ & $\begin{array}{l}15.3 \\
57.9 \\
57.6 \\
19.2\end{array}$ & $\begin{array}{l}-- \\
-- \\
-- \\
--\end{array}$ & $\begin{array}{r}1.3 \\
3.3 \\
1.2 \\
--\end{array}$ & $\begin{array}{l}-- \\
-- \\
-- \\
--\end{array}$ & $\begin{array}{l}-- \\
-- \\
-- \\
--\end{array}$ & $\begin{array}{l}-- \\
-- \\
-- \\
--\end{array}$ & $\begin{array}{r}9.5 \\
46.1 \\
42.9 \\
16.1\end{array}$ & $\begin{array}{r}4.5 \\
8.5 \\
13.5 \\
3.1\end{array}$ \\
\hline All stands & 150.0 & -- & 5.8 & -- & -- & -- & 114.6 & 29.6 \\
\hline
\end{tabular}


Table 35.--Area of wooded strips by forest type and site-index class, Kansas, 1981

(In thousand acres)

\begin{tabular}{|c|c|c|c|c|c|c|c|c|c|}
\hline \multirow[b]{2}{*}{ Forest type } & \multirow{2}{*}{$\begin{array}{c}\text { A11 } \\
\text { classes }\end{array}$} & \multicolumn{8}{|c|}{ Site-index class (feet) } \\
\hline & & $21-30$ & $31-40$ & $41-50$ & $51-60$ & $61-70$ & $71-80$ & $81-90$ & $91+$ \\
\hline Eastern redcedar-hardwood & 5.3 & - & -- & 1.9 & 3.4 & -- & - & -- & - \\
\hline 0ak-hickory & 5.1 & -- & -- & 2.4 & - & 2.7 & -- & -- & -- \\
\hline Post-blackjack oak & -- & -- & -- & -- & -- & -- & -- & -- & -- \\
\hline Upland plains hardwoods & 6.4 & -- & -- & 5.5 & -- & -- & 0.9 & -- & - \\
\hline Elm-ash-cott onwood & 51.8 & -- & 1.2 & 19.2 & 9.9 & 15.3 & 1.5 & 4.7 & -- \\
\hline Cottonwood & 5.1 & -- & -- & 2.5 & 2.6 & -- & -- & -- & -- \\
\hline Willow & 2.0 & -- & -- & 1.0 & - & -- & -- & 1.0 & - \\
\hline Lowland plains hardwoods & 35.2 & -- & -- & 20.5 & 4.7 & 7.2 & 1.4 & 1.4 & -- \\
\hline Upland elm-ash-1ocust & 19.9 & -- & -- & 9.6 & 6.6 & 3.7 & -- & -- & -- \\
\hline Nonstocked & 19.2 & -- & -- & 10.4 & 4.7 & 3.1 & 1.0 & $=$ & -- \\
\hline A11 types & 150.0 & -- & 1.2 & 73.0 & 31.9 & 32.0 & 4.8 & 7.1 & $=-$ \\
\hline
\end{tabular}




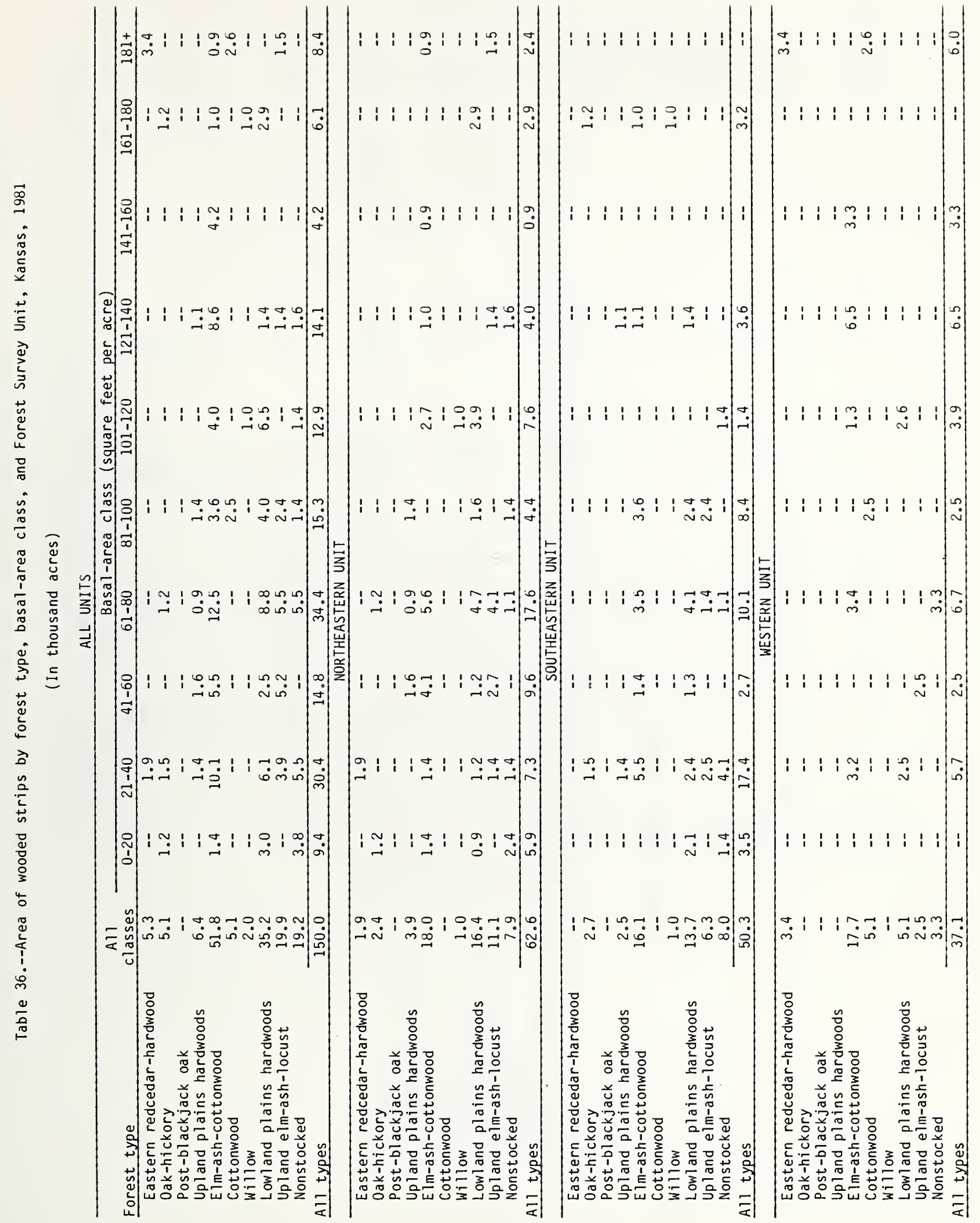




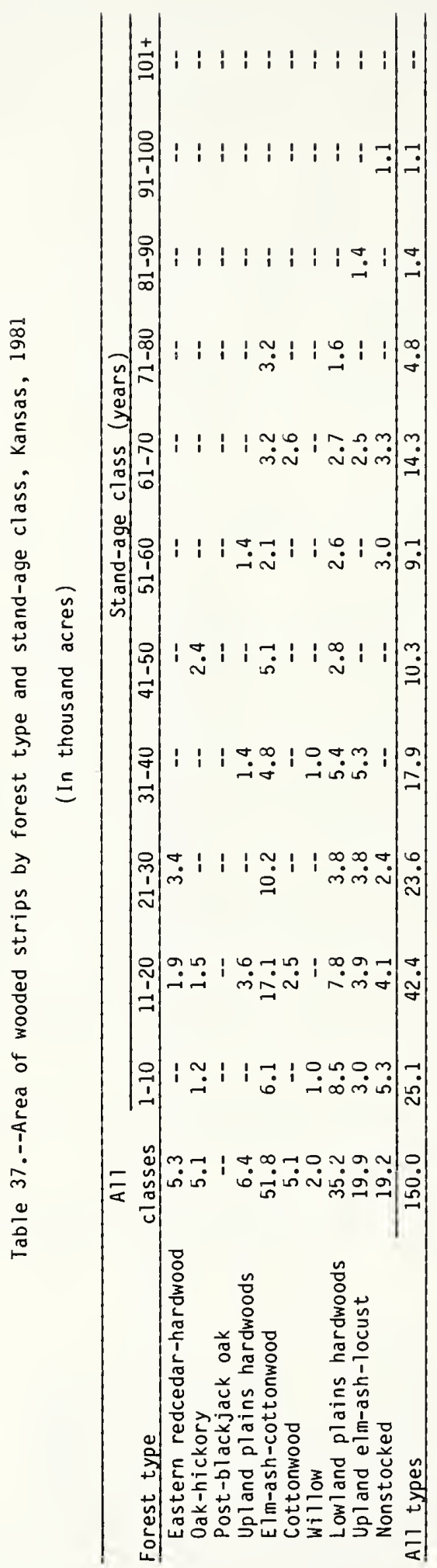


Table 38.--Area of wooded strips by forest type, physiographic class, and ownership class, Kansas, 1981

(In thousand acres)

\begin{tabular}{|c|c|c|c|c|c|c|c|c|}
\hline \multirow[b]{2}{*}{$\begin{array}{l}\text { Forest type and } \\
\text { physiographic class }\end{array}$} & \multirow[b]{2}{*}{$\begin{array}{c}\text { All } \\
\text { classes }\end{array}$} & \multicolumn{7}{|c|}{ Ownership class } \\
\hline & & $\begin{array}{c}\text { National } \\
\text { Forest } \\
\end{array}$ & $\begin{array}{l}\text { Misc. } \\
\text { federal }\end{array}$ & Indian & State & $\begin{array}{l}\text { County and } \\
\text { municipal }\end{array}$ & Farmer & $\begin{array}{l}\text { Misc. } \\
\text { private }\end{array}$ \\
\hline \multicolumn{9}{|c|}{ Eastern redcedar-hardwood } \\
\hline Hydric & -- & -- & -- & -- & -- & -- & -- & -- \\
\hline Hydromes ic & -- & -- & -- & -- & -- & -- & -- & -- \\
\hline Mesic & -- & - & -- & -- & -- & -- & - & - \\
\hline Xeromesic & 5.3 & -- & -- & -- & -- & -- & 5.3 & -- \\
\hline Xeric & -- & -- & -- & - & -- & -- & -- & -- \\
\hline All classes & 5.3 & -- & -- & -- & -- & -- & 5.3 & -- \\
\hline \multicolumn{9}{|l|}{ 0ak-hickory } \\
\hline Hydric & -- & -- & -- & -- & -- & -- & -- & -- \\
\hline Hydromesic & 1.5 & -- & -- & -- & -- & -- & 1.5 & -- \\
\hline Mesic & 3.6 & -- & -- & -- & -- & -- & 3.6 & -- \\
\hline Xeromesic & -- & -- & -- & -- & -- & -- & -- & -- \\
\hline Xeric & -- & -- & -- & -- & -- & -- & -- & -- \\
\hline All classes & 5.1 & - & -- & -- & -- & - & 5.1 & -- \\
\hline \multicolumn{9}{|l|}{ Post-blackjack oak } \\
\hline Hydric & -- & -- & -- & -- & -- & -- & -- & -- \\
\hline Hydromesic & -- & -- & -- & -- & -- & -- & -- & -- \\
\hline Mesic & -- & -- & -- & -- & -- & -- & -- & -- \\
\hline Xeromesic & -- & -- & -- & -- & -- & -- & -- & -- \\
\hline Xeric & -- & -- & -- & -- & -- & -- & -- & -- \\
\hline All classes & $=$ & -- & -- & -- & -- & -- & -- & -- \\
\hline \multicolumn{9}{|c|}{ Upland plains hardwoods } \\
\hline Hydric & -- & -- & -- & -- & -- & -- & -- & -- \\
\hline Hydromes ic & -- & -- & -- & -- & -- & -- & -- & -- \\
\hline Mesic & 1.4 & -- & -- & -- & -- & -- & 1.4 & -- \\
\hline Xeromesic & 5.0 & -- & -- & -- & -- & -- & 3.4 & 1.6 \\
\hline Xeric & -- & -- & -- & -- & -- & -- & -- & -- \\
\hline All classes & 6.4 & -- & -- & -- & -- & -- & 4.8 & 1.6 \\
\hline \multicolumn{9}{|l|}{ Elm-ash-cottonwood } \\
\hline Hydric & -- & -- & -- & -- & -- & -- & -- & - \\
\hline Hydromesic & 12.9 & -- & 3.3 & -- & -- & -- & 5.0 & 4.6 \\
\hline Mesic & 38.9 & -- & 1.3 & -- & -- & -- & 33.5 & 4.1 \\
\hline Xeromesic & -- & -- & -- & -- & -- & -- & -- & -- \\
\hline Xeric & -- & -- & -- & -- & -- & - & - & $=-$ \\
\hline All classes & 51.8 & -- & 4.6 & -- & -- & -- & 38.5 & 8.7 \\
\hline \multicolumn{9}{|l|}{ Cottonwood } \\
\hline Hydric & -- & -- & -- & -- & -- & -- & -- & - \\
\hline Hydromesic & 2.6 & -- & -- & -- & -- & -- & -- & 2.6 \\
\hline Mesic & -- & -- & -- & -- & - & -- & -- & -- \\
\hline Xeromesic & 2.5 & -- & -- & -- & -- & -- & 2.5 & $-\infty$ \\
\hline Xeric & -- & - & -- & -- & - & - & -- & -- \\
\hline All classes & 5.1 & $=$ & $=$ & - & - & - & 2.5 & 2.6 \\
\hline
\end{tabular}


(Table 38 continued)

\begin{tabular}{|c|c|c|c|c|c|c|c|c|}
\hline \multirow[b]{2}{*}{$\begin{array}{l}\text { Forest type and } \\
\text { physiographic class }\end{array}$} & \multirow[b]{2}{*}{$\begin{array}{c}\text { All } \\
\text { classes }\end{array}$} & \multicolumn{7}{|c|}{ Ownership class } \\
\hline & & $\begin{array}{l}\text { National } \\
\text { Forest }\end{array}$ & $\begin{array}{c}\text { Misc. } \\
\text { federal }\end{array}$ & Indian & State & $\begin{array}{r}\text { County and } \\
\text { municipal }\end{array}$ & Farmer & $\begin{array}{l}\text { Misc. } \\
\text { private }\end{array}$ \\
\hline \multicolumn{9}{|l|}{ Willow } \\
\hline Hydric & -- & -- & -- & -- & -- & -- & -- & -- \\
\hline Hydromesic & 1.0 & -- & -- & -- & -- & -- & 1.0 & -- \\
\hline Mesic & 1.0 & -- & -- & -- & -- & -- & 1.0 & -- \\
\hline Xeromesic & -- & -- & -- & -- & -- & -- & -- & -- \\
\hline Xeric & -- & -- & -- & -- & -- & -- & -- & -- \\
\hline All classes & 2.0 & -- & -- & -- & -- & -- & 2.0 & -- \\
\hline \multicolumn{9}{|c|}{ Lowl and plains hardwoods } \\
\hline Hydric & 1.4 & -- & -- & -- & -- & -- & 1.4 & -- \\
\hline Hydromesic & 10.9 & -- & -- & -- & -- & -- & 10.0 & 0.9 \\
\hline Mesic & 22.9 & -- & -- & -- & -- & -- & 18.3 & 4.6 \\
\hline Xeromesic & -- & -- & -- & -- & -- & -- & -- & -- \\
\hline Xeric & -- & -- & -- & -- & -- & -- & -- & -- \\
\hline All classes & 35.2 & - & -- & -- & -- & -- & 29.7 & 5.5 \\
\hline \multicolumn{9}{|l|}{ Upland elm-ash-locust } \\
\hline Hydric & -- & -- & -- & -- & -- & -- & -- & -- \\
\hline Hydromesic & -- & -- & -- & -- & -- & -- & -- & -- \\
\hline Mesic & 1.5 & -- & -- & -- & -- & -- & -- & 1.5 \\
\hline Xeromesic & 15.6 & -- & 1.2 & -- & -- & -- & 7.8 & 6.6 \\
\hline Xeric & 2.8 & -- & -- & -- & -- & -- & 2.8 & -- \\
\hline All classes & 19.9 & $=$ & 1.2 & -- & $=$ & $=$ & 10.6 & 8.1 \\
\hline \multicolumn{9}{|l|}{ Nonstocked } \\
\hline Hydric & -- & -- & -- & -- & -- & -- & -- & -- \\
\hline Hydromesic & 1.4 & -- & -- & -- & -- & -- & 1.4 & -- \\
\hline Mesic & 10.8 & -- & -- & -- & -- & -- & 7.7 & 3.1 \\
\hline Xeromesic & 7.0 & -- & -- & -- & -- & -- & 7.0 & -- \\
\hline Xeric & -- & -- & -- & -- & -- & -- & -- & -- \\
\hline All classes & 19.2 & -- & -- & -- & -- & -- & 16.1 & 3.1 \\
\hline \multicolumn{9}{|l|}{ All types } \\
\hline Hydric & 1.4 & -- & -- & -- & -- & -- & 1.4 & -- \\
\hline Hydromes ic & 30.3 & -- & 3.3 & -- & -- & -- & 18.9 & 8.1 \\
\hline Mesic & 80.1 & -- & 1.3 & -- & -- & -- & 65.5 & 13.3 \\
\hline Xeromesic & 35.4 & $=-$ & 1.2 & -- & -- & -- & 26.0 & 8.2 \\
\hline Xeric & 2.8 & -- & -- & $=$ & -- & $=-$ & 2.8 & -- \\
\hline All classes & 150.0 & -- & 5.8 & -- & -- & -- & 114.6 & 29.6 \\
\hline
\end{tabular}


Table 39.--Area of wooded strips in private ownership by ownership class, owner tenure, and ownership-size class, Kansas, 1981

(In thousand acres)

ALL UNITS

\begin{tabular}{|c|c|c|c|c|c|c|c|c|}
\hline \multirow{2}{*}{$\begin{array}{l}\text { Ownership class } \\
\text { and owner tenure }\end{array}$} & \multirow{2}{*}{$\begin{array}{c}\text { All } \\
\text { classes }\end{array}$} & \multicolumn{7}{|c|}{ Ownership-size class (acres) } \\
\hline & & $1-5$ & $5-10$ & $10-20$ & $20-50$ & $50-100$ & $100-500$ & $500+$ \\
\hline $\begin{array}{c}\text { Farmer } \\
1-4 \text { years } \\
5-9 \text { years } \\
10-19 \text { years } \\
20+\text { years }\end{array}$ & $\begin{array}{l}14.2 \\
19.3 \\
24.5 \\
56.7 \\
\end{array}$ & $\begin{array}{r}-- \\
3.3 \\
-- \\
1.6 \\
\end{array}$ & $\begin{array}{r}3.7 \\
4.1 \\
8.2 \\
25.9 \\
\end{array}$ & $\begin{array}{r}5.1 \\
6.2 \\
7.9 \\
15.9 \\
\end{array}$ & $\begin{array}{l}1.0 \\
2.9 \\
7.1 \\
8.7 \\
\end{array}$ & $\begin{array}{l}4.4 \\
2.8 \\
1.3 \\
2.4 \\
\end{array}$ & $\begin{array}{l}-- \\
-- \\
-- \\
2.2 \\
\end{array}$ & $\begin{array}{l}-- \\
-- \\
-- \\
-- \\
\end{array}$ \\
\hline Total & 114.7 & 4.9 & 41.9 & 35.1 & 19.7 & 10.9 & 2.2 & $=$ \\
\hline $\begin{array}{c}\text { Miscellaneous pr } \\
\text { corporation } \\
1-4 \text { years } \\
5-9 \text { years } \\
10-19 \text { years } \\
20+\text { years }\end{array}$ & $\begin{array}{r}1.4 \\
1.0 \\
-- \\
-- \\
\end{array}$ & $\begin{array}{l}-- \\
-- \\
-- \\
--\end{array}$ & $\begin{array}{r}1.4 \\
-- \\
-- \\
-- \\
\end{array}$ & $\begin{array}{l}-- \\
-- \\
-- \\
\end{array}$ & $\begin{array}{l}-- \\
-- \\
-- \\
-\end{array}$ & $\begin{array}{l}-- \\
-- \\
-- \\
-- \\
\end{array}$ & $\begin{array}{r}-- \\
1.0 \\
-- \\
-- \\
\end{array}$ & $\begin{array}{l}-- \\
-- \\
-- \\
-- \\
\end{array}$ \\
\hline Total & 2.4 & $=$ & 1.4 & -- & - & -- & 1.0 & -- \\
\hline $\begin{array}{c}\text { Miscellaneous pr } \\
\text { individual } \\
1-4 \text { years } \\
5-9 \text { years } \\
10-19 \text { years } \\
20+\text { years }\end{array}$ & $\begin{array}{r}3.7 \\
4.4 \\
5.2 \\
13.8 \\
\end{array}$ & $\begin{array}{l}-- \\
3.0 \\
0.9 \\
1.4 \\
\end{array}$ & $\begin{array}{r}-- \\
1.4 \\
-- \\
2.5 \\
\end{array}$ & $\begin{array}{r}2.3 \\
-- \\
4.3 \\
7.3 \\
\end{array}$ & $\begin{array}{r}1.4 \\
-- \\
-- \\
-- \\
\end{array}$ & $\begin{array}{l}-- \\
-- \\
-- \\
1.6 \\
\end{array}$ & $\begin{array}{l}-- \\
-- \\
-- \\
1.0 \\
\end{array}$ & $\begin{array}{l}-- \\
-- \\
-- \\
-- \\
\end{array}$ \\
\hline Total & 27.1 & 5.3 & 3.9 & 13.9 & 1.4 & 1.6 & 1.0 & -- \\
\hline $\begin{array}{l}\text { A11 owners } \\
1-4 \text { years } \\
5-9 \text { years } \\
10-19 \text { years } \\
20+\text { years }\end{array}$ & $\begin{array}{l}19.3 \\
24.7 \\
29.7 \\
70.5 \\
\end{array}$ & $\begin{array}{l}-- \\
6.3 \\
0.9 \\
3.0 \\
\end{array}$ & $\begin{array}{r}5.1 \\
5.5 \\
8.2 \\
28.4 \\
\end{array}$ & $\begin{array}{r}7.4 \\
6.2 \\
12.2 \\
23.2 \\
\end{array}$ & $\begin{array}{l}2.4 \\
2.9 \\
7.1 \\
8.7 \\
\end{array}$ & $\begin{array}{l}4.4 \\
2.8 \\
1.3 \\
4.0 \\
\end{array}$ & $\begin{array}{r}-- \\
1.0 \\
-- \\
3.2 \\
\end{array}$ & $\begin{array}{l}-- \\
-- \\
-- \\
-- \\
\end{array}$ \\
\hline Total & 144.2 & 10.2 & 47.2 & 49.0 & 21.1 & 12.5 & 4.2 & -- \\
\hline \multicolumn{9}{|c|}{ NORTHEASTERN UNIT } \\
\hline $\begin{array}{l}\text { Farmer } \\
\begin{array}{l}1-4 \text { years } \\
5-9 \text { years } \\
10-19 \text { years } \\
20+\text { years }\end{array}\end{array}$ & $\begin{array}{r}7.1 \\
11.4 \\
12.1 \\
18.5 \\
\end{array}$ & $\begin{array}{l}-- \\
-- \\
-- \\
1.6 \\
\end{array}$ & $\begin{array}{l}1.5 \\
2.7 \\
5.6 \\
5.5 \\
\end{array}$ & $\begin{array}{l}1.2 \\
4.6 \\
2.9 \\
5.0 \\
\end{array}$ & $\begin{array}{r}-- \\
2.9 \\
3.6 \\
4.2 \\
\end{array}$ & $\begin{array}{c}4.4 \\
1.2 \\
-. \\
-- \\
\end{array}$ & $\begin{array}{l}-- \\
-- \\
-- \\
2.2 \\
\end{array}$ & $\begin{array}{l}-- \\
-- \\
-- \\
--\end{array}$ \\
\hline Total & 49.1 & 1.6 & 15.3 & 13.7 & 10.7 & 5.6 & 2.2 & -- \\
\hline $\begin{array}{c}\text { Miscellaneous } p r \\
\text { corporation } \\
1-4 \text { years } \\
5-9 \text { years } \\
10-19 \text { years } \\
20+\text { years }\end{array}$ & $\begin{array}{c}1.4 \\
-- \\
-- \\
-- \\
\end{array}$ & $\begin{array}{l}-- \\
-- \\
-- \\
--\end{array}$ & $\begin{array}{r}1.4 \\
-- \\
-- \\
-- \\
\end{array}$ & $\begin{array}{l}-- \\
-- \\
-- \\
-\end{array}$ & $\begin{array}{l}-- \\
-- \\
-- \\
--\end{array}$ & $\begin{array}{l}-- \\
-- \\
-- \\
--\end{array}$ & $\begin{array}{l}-- \\
-- \\
-- \\
-- \\
\end{array}$ & $\begin{array}{l}-- \\
-- \\
-- \\
-- \\
\end{array}$ \\
\hline Total & 1.4 & $=$ & 1.4 & -- & - & - & -- & -- \\
\hline $\begin{array}{c}\text { Miscellaneous pri } \\
\text { individual } \\
1-4 \text { years } \\
5-9 \text { years } \\
10-19 \text { years } \\
20+\text { years }\end{array}$ & $\begin{array}{r}-- \\
3.0 \\
2.5 \\
6.6 \\
\end{array}$ & $\begin{array}{l}-- \\
3.0 \\
0.9 \\
1.4 \\
\end{array}$ & $\begin{array}{l}-- \\
-- \\
-- \\
--\end{array}$ & $\begin{array}{r}-- \\
-- \\
1.6 \\
2.6 \\
\end{array}$ & $\begin{array}{l}-- \\
-- \\
-- \\
-\end{array}$ & $\begin{array}{r}-- \\
-- \\
1.6 \\
\end{array}$ & $\begin{array}{l}-- \\
-- \\
-- \\
1.0 \\
\end{array}$ & $\begin{array}{l}-- \\
-- \\
-- \\
-- \\
\end{array}$ \\
\hline Total & 12.1 & 5.3 & -- & 4.2 & -- & 1.6 & 1.0 & -- \\
\hline $\begin{array}{l}\text { A11 owners } \\
1-4 \text { years } \\
5-9 \text { years } \\
10-19 \text { years } \\
20+\text { years }\end{array}$ & $\begin{array}{r}8.5 \\
14.4 \\
14.6 \\
25.1 \\
\end{array}$ & $\begin{array}{l}-- \\
3.0 \\
0.9 \\
3.0 \\
\end{array}$ & $\begin{array}{l}2.9 \\
2.7 \\
5.6 \\
5.5 \\
\end{array}$ & $\begin{array}{l}1.2 \\
4.6 \\
4.5 \\
7.6 \\
\end{array}$ & $\begin{array}{r}-- \\
2.9 \\
3.6 \\
4.2 \\
\end{array}$ & $\begin{array}{r}4.4 \\
1.2 \\
-- \\
1.6 \\
\end{array}$ & $\begin{array}{l}-- \\
-- \\
-- \\
.2 \\
\end{array}$ & $\begin{array}{l}-- \\
-- \\
-- \\
--\end{array}$ \\
\hline Total & 62.6 & 6.9 & 16.7 & 17.9 & 10.7 & 7.2 & 3.2 & -- \\
\hline
\end{tabular}


(Table 39 continued)

SOUTHEASTERN UNIT

\begin{tabular}{lccccccccc}
\hline Ownership class & A11 & \multicolumn{6}{c}{ Ownership-size class (acres) } \\
\cline { 5 - 9 } and owner tenure & classes & $1-5$ & $5-10$ & $10-20$ & $20-50$ & $50-100$ & $100-500$ & $500+$ \\
\hline Farmer & & & & & & & & -- \\
$1-4$ & years & 7.1 & -- & 2.2 & 3.9 & 1.0 & -- & -- & -- \\
$5-9$ years & 4.6 & -- & 1.4 & 1.6 & -- & 1.6 & -- & -- \\
$10-19$ years & 12.4 & -- & 2.6 & 5.0 & 3.5 & 1.3 & -- & -- \\
$20+$ years & 13.4 & -- & 2.4 & 7.5 & 1.1 & 2.4 & -- & -- \\
$\quad$ Total & 37.5 & -- & 8.6 & 18.0 & 5.6 & 5.3 & -- & -- \\
\hline
\end{tabular}

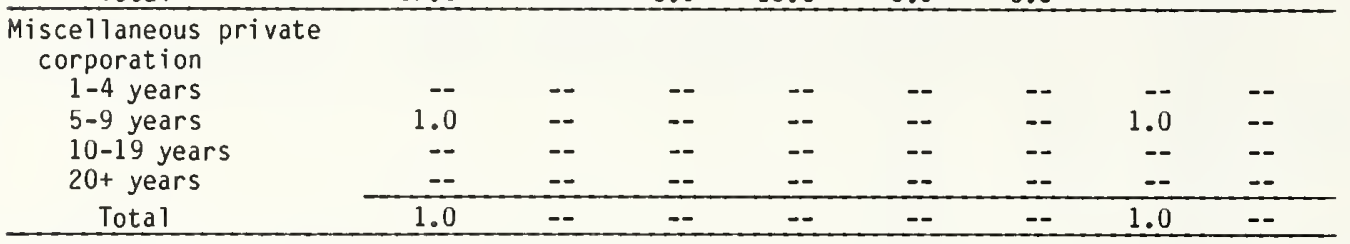

Miscellaneous private individual

\begin{tabular}{|c|c|c|c|c|c|c|c|c|}
\hline $\begin{array}{l}1-4 \text { years } \\
5-9 \text { years } \\
10-19 \text { years } \\
20+\text { years }\end{array}$ & $\begin{array}{l}3.7 \\
1.4 \\
2.7 \\
1.4\end{array}$ & $\begin{array}{l}-- \\
-- \\
-- \\
--\end{array}$ & $\begin{array}{r}-- \\
1.4 \\
-- \\
-\end{array}$ & $\begin{array}{r}2.3 \\
-. \\
2.7 \\
1.4\end{array}$ & $\begin{array}{c}1.4 \\
-- \\
-- \\
--\end{array}$ & $\begin{array}{l}-- \\
-- \\
-- \\
--\end{array}$ & $\begin{array}{l}-- \\
-- \\
--\end{array}$ & $\begin{array}{l}-- \\
-- \\
-- \\
--\end{array}$ \\
\hline Total & 9.2 & -- & 1.4 & 6.4 & 1.4 & -- & -- & -- \\
\hline
\end{tabular}

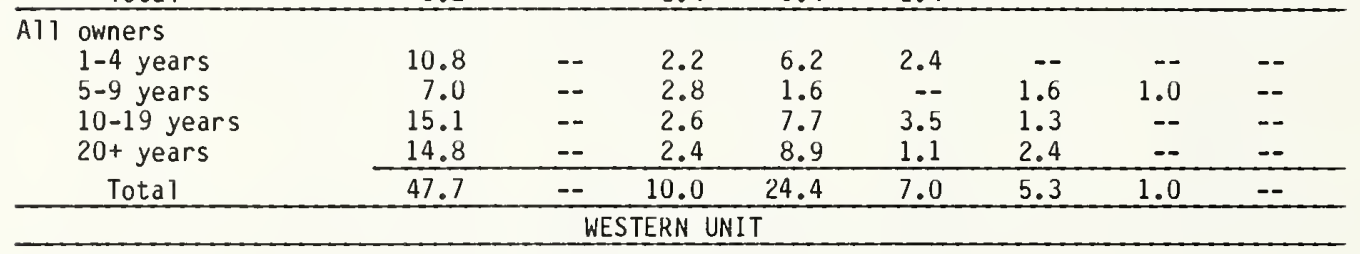

\begin{tabular}{|c|c|c|c|c|c|c|c|c|}
\hline \multicolumn{9}{|l|}{ Farmer } \\
\hline $1-4$ years & - & -- & -- & -- & -- & -- & - & - \\
\hline $5-9$ years & 3.3 & 3.3 & -- & -- & -- & -- & -- & -- \\
\hline $10-19$ years & -- & -- & -- & -- & -- & -- & -- & -- \\
\hline $20+$ years & 24.8 & -- & 18.0 & 3.4 & 3.4 & -- & -- & -- \\
\hline Tota 1 & 28.1 & 3.3 & 18.0 & 3.4 & 3.4 & -- & -- & -- \\
\hline
\end{tabular}

\begin{tabular}{|c|c|c|c|c|c|c|c|c|}
\hline \multicolumn{9}{|c|}{$\begin{array}{l}\text { Miscellaneous private } \\
\text { corporation }\end{array}$} \\
\hline $1-4$ years & -- & - & -- & -- & -- & -- & -- & -- \\
\hline $5-9$ years & -- & -- & -- & -- & -- & -- & -- & -- \\
\hline $10-19$ years & -- & -- & -- & - & -- & - & -- & $=-$ \\
\hline $20+$ years & $=$ & $=-$ & $=$ & $=$ & -- & $=$ & -- & $=$ \\
\hline Tota 1 & $\because$ & -- & -- & $=$ & -- & -- & -- & - \\
\hline
\end{tabular}

\begin{tabular}{|c|c|c|c|c|c|c|c|c|}
\hline \multicolumn{9}{|l|}{$\begin{array}{l}\text { Miscellaneous private } \\
\text { individual }\end{array}$} \\
\hline 1-4 years & -- & -- & -- & -- & -- & -- & -- & - \\
\hline 5-9 years & -- & -- & -- & -- & -- & -- & -- & -- \\
\hline $10-19$ years & -- & -- & -- & -- & -- & -- & -- & -- \\
\hline $20+$ years & 5.8 & -- & 2.5 & 3.3 & -- & -- & -- & -- \\
\hline Total & 5.8 & -- & 2.5 & 3.3 & -- & -- & -- & -- \\
\hline \multicolumn{9}{|l|}{ A11 owners } \\
\hline 1-4 years & -- & -- & -- & -- & -- & $=-$ & -- & -- \\
\hline 5-9 years & 3.3 & 3.3 & -- & -- & -- & -- & -- & -- \\
\hline $10-19$ years & -- & -- & -- & $\cdots$ & - & -- & -- & -- \\
\hline $20+$ years & 30.6 & -- & 20.5 & 6.7 & 3.4 & -- & -- & -- \\
\hline Total & 33.9 & 3.3 & 20.5 & 6.7 & 3.4 & -- & -- & -- \\
\hline
\end{tabular}




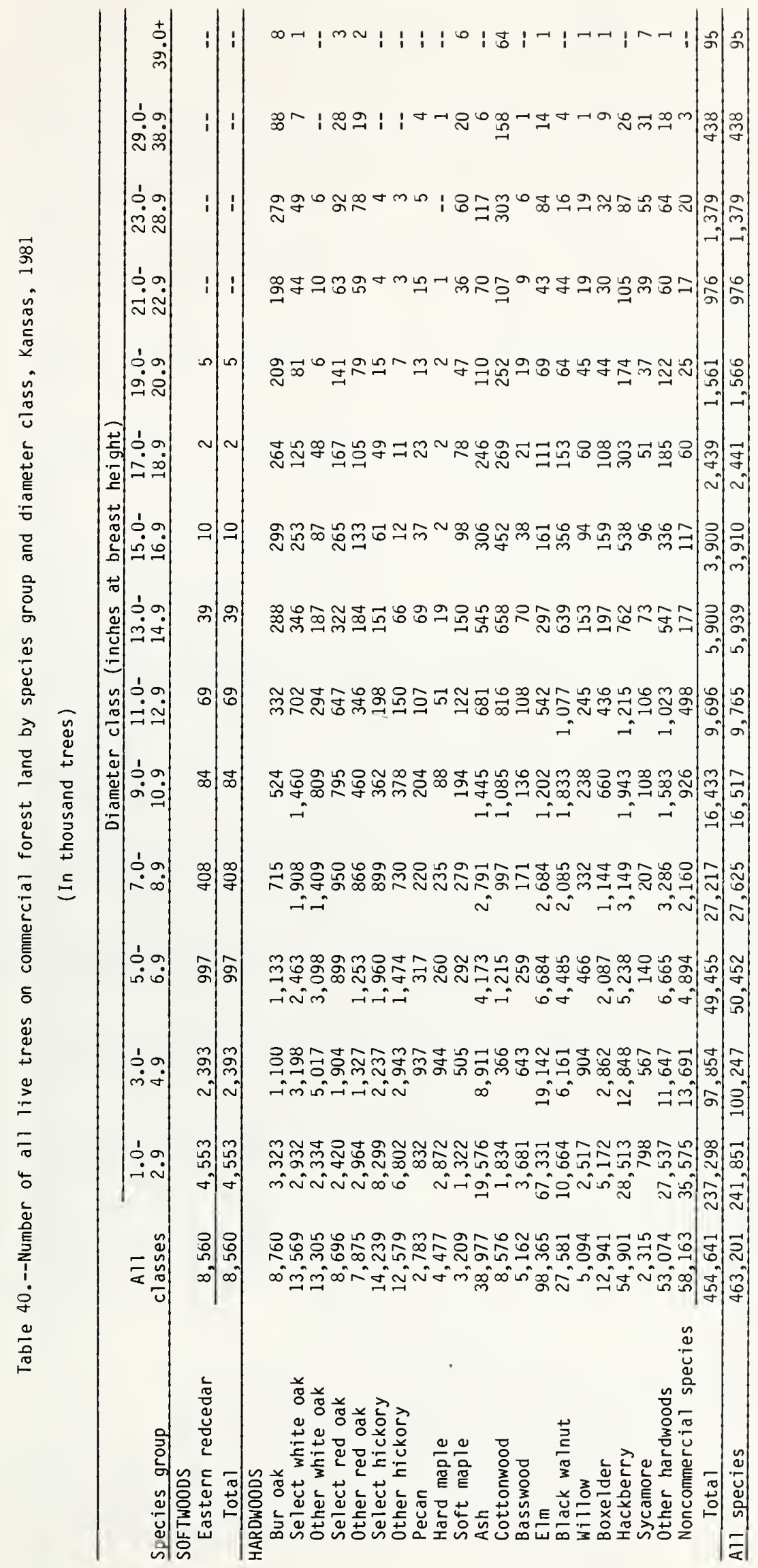




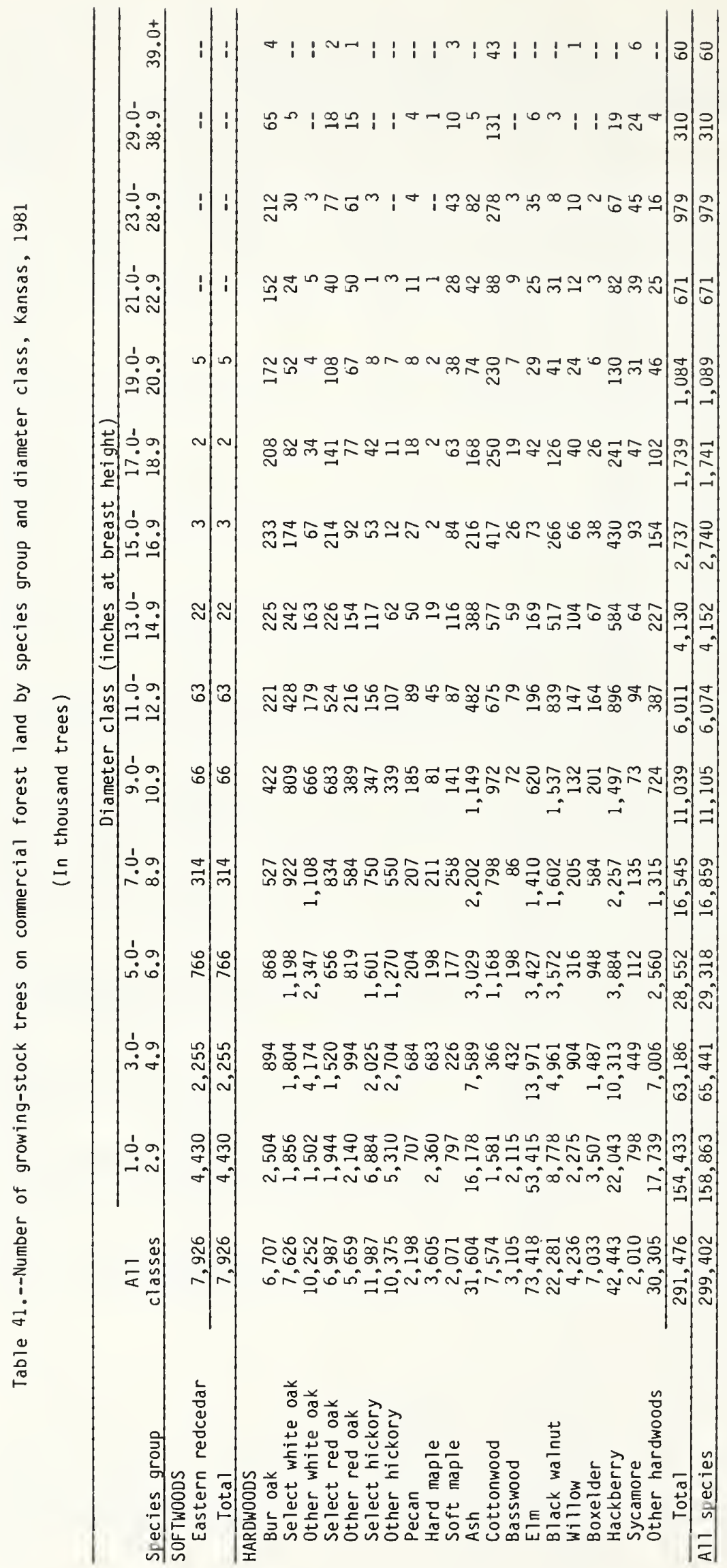




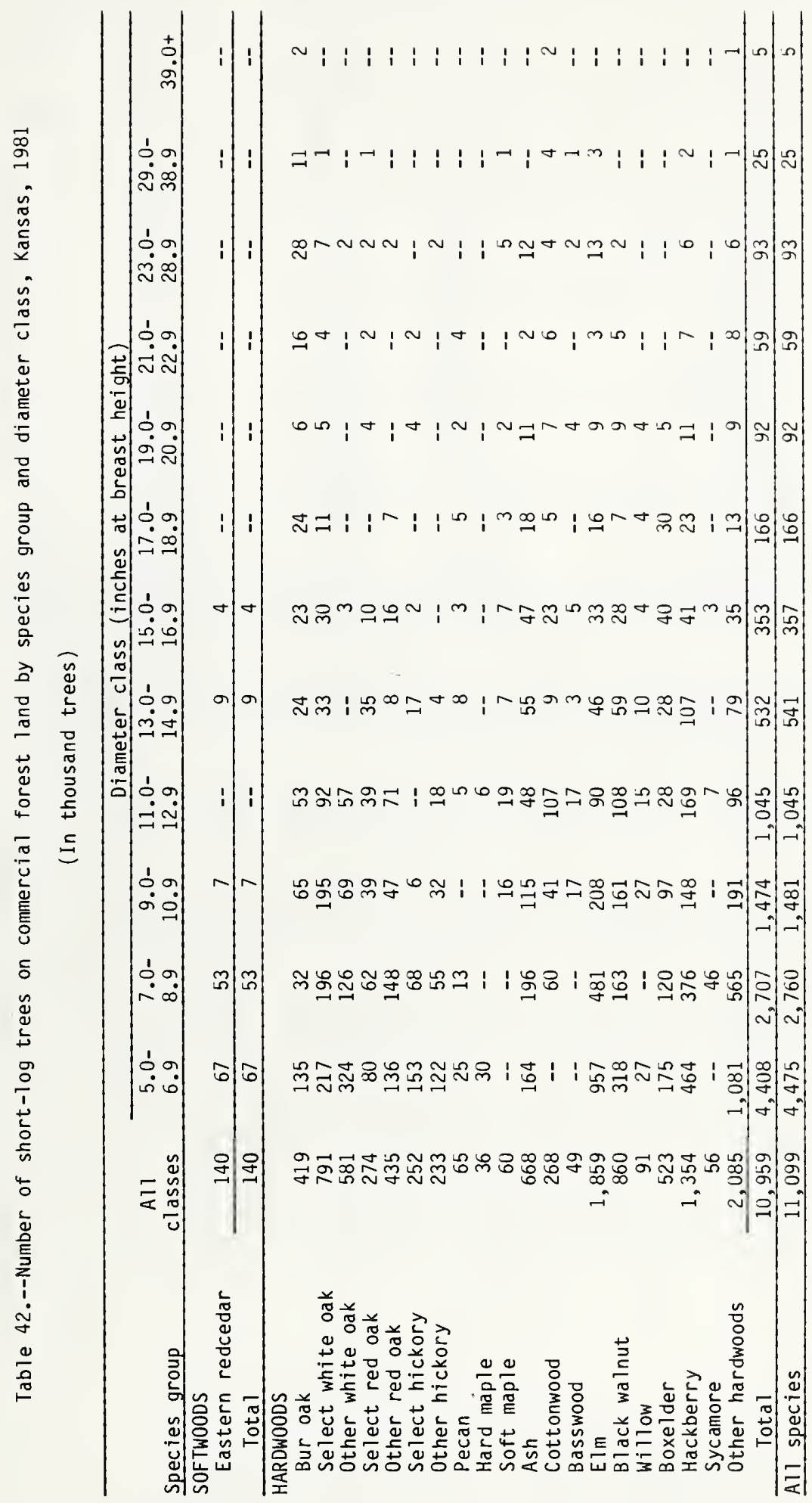


Table 43.--Net volume of growing stock and sawtimber on commercial forest land by species group, Kansas, 1965 and 1981

\begin{tabular}{|c|c|c|c|c|}
\hline \multirow[b]{2}{*}{ Species group } & \multicolumn{2}{|c|}{ Growing stock } & \multicolumn{2}{|c|}{ Sawt imber } \\
\hline & 196511 & 1981 & $1965=1 /$ & 1981 \\
\hline & \multicolumn{2}{|c|}{ Thousand cubic feet } & \multicolumn{2}{|c|}{ Thousand board feet -2} \\
\hline $\begin{array}{l}\text { SOFTWOODS } \\
\text { Eastern redcedar }\end{array}$ & 216 & 4,591 & 511 & 10,871 \\
\hline Tota 1 & 216 & 4,591 & 511 & 10,871 \\
\hline HARDW00DS & & & & \\
\hline $\begin{array}{l}\text { Bur oak } \\
\text { Select white oak } \\
\text { Other white oak } \\
\text { Select red oak } \\
\text { Other red oak } \\
\text { Hickory } \\
\text { Pecan } \\
\text { Hard maple } \\
\text { Soft maple } \\
\text { Ash } \\
\text { Cottonwood } \\
\text { Basswood } \\
\text { Elm } \\
\text { Black walnut } \\
\text { Willow } \\
\text { Hackberry } \\
\text { Sycamore } \\
\text { Other hardwoods }\end{array}$ & $\begin{array}{r}36,925 \\
11,501 \\
10,484 \\
26,020 \\
19,438 \\
13,103 \\
8,040 \\
2,259 \\
9,005 \\
35,714 \\
101,052 \\
3,614 \\
89 ; 243 \\
36,751 \\
10,772 \\
48,909 \\
24,613 \\
14,941 \\
\end{array}$ & $\begin{array}{r}60,920 \\
34,121 \\
19,854 \\
45,828 \\
27,445 \\
29,081 \\
8,986 \\
3,120 \\
21,011 \\
61,700 \\
134,292 \\
6,031 \\
30,599 \\
57,868 \\
11,629 \\
86,674 \\
21,538 \\
46,027 \\
\end{array}$ & $\begin{array}{r}173,124 \\
36,194 \\
19,229 \\
103,966 \\
84,208 \\
30,502 \\
36,974 \\
5,563 \\
37,644 \\
107,524 \\
459,058 \\
15,438 \\
358,279 \\
107,950 \\
44,370 \\
169,049 \\
125,288 \\
38,675 \\
\end{array}$ & $\begin{array}{r}286,120 \\
107,383 \\
36,531 \\
183,457 \\
118,665 \\
67,696 \\
28,043 \\
6,280 \\
87,834 \\
185,760 \\
610,060 \\
25,763 \\
69,531 \\
169,979 \\
47,901 \\
299,581 \\
105,631 \\
119,143 \\
\end{array}$ \\
\hline Total & 502,384 & 706,724 & $1,953,035$ & $2,555,358$ \\
\hline Al1 species & 502,600 & 711,315 & $1,953,546$ & $2,566,229$ \\
\hline
\end{tabular}

1/Figures have been adjusted from those published after the 1965 survey to conform to 1981 areas because of changes in survey definitions and procedures.

2/International $1 / 4$-inch rule. 


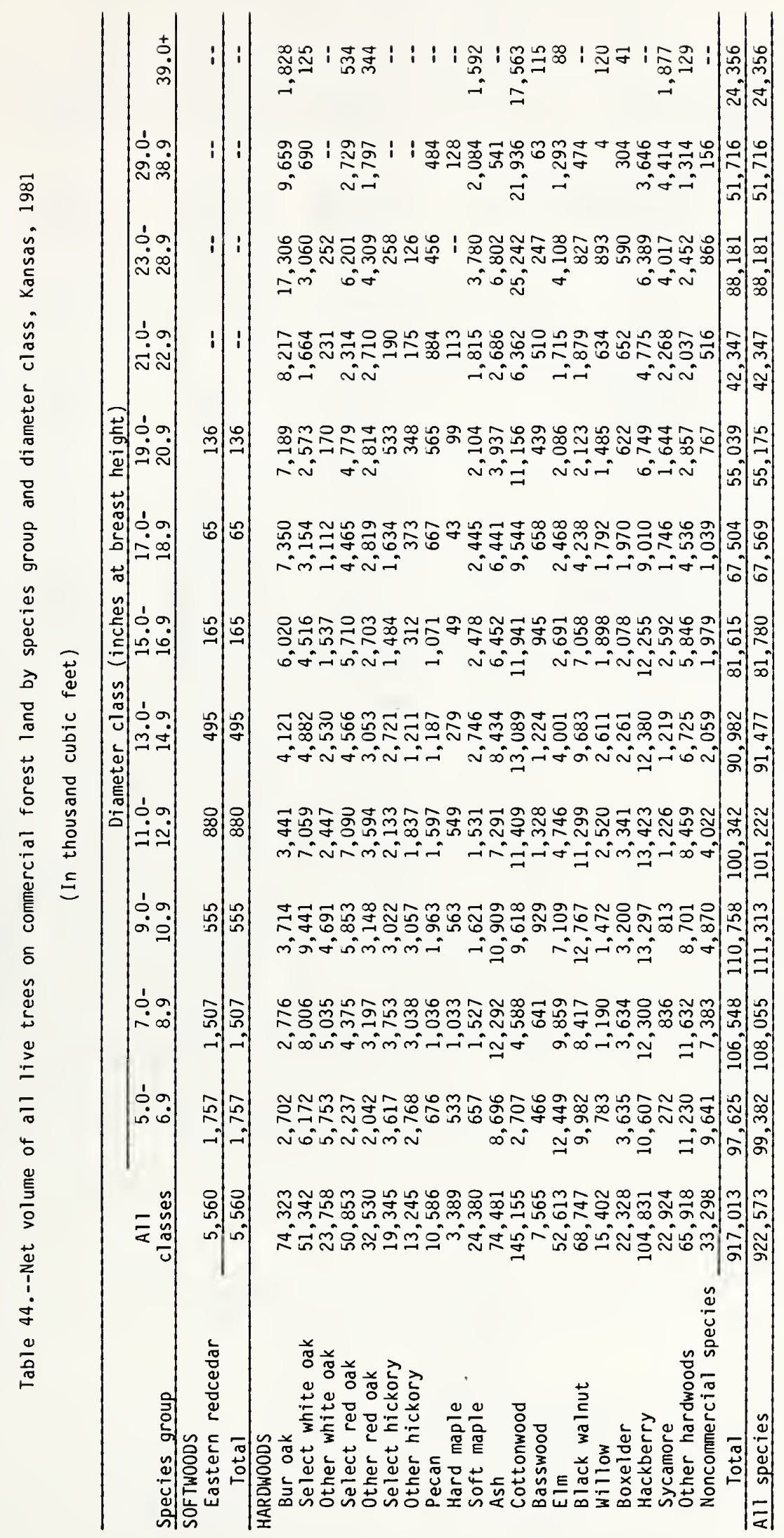


Table 45.--Net volume of timber on commercial forest land by

class of timber and softwoods and hardwoods, Kansas, 1981

(In thousand cubic feet)

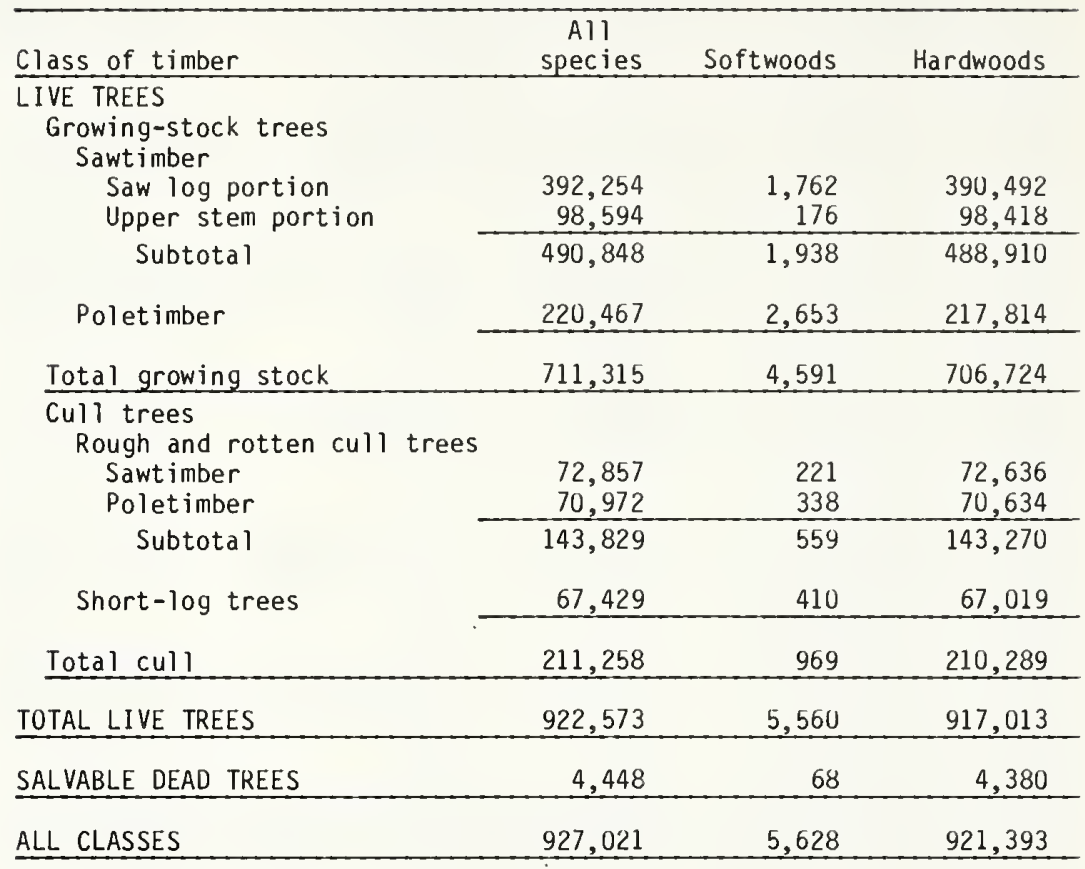


Table 46.--Net volume of growing-stock, sawtimber, short-log, and rough and rotten trees on commercial forest land by individual species, Kansas, 1981

\begin{tabular}{|c|c|c|c|c|c|}
\hline Species & $\begin{array}{l}\text { Total } \\
\text { all live }\end{array}$ & $\begin{array}{c}\text { Growing } \\
\text { stock }\end{array}$ & $\begin{array}{c}\text { Short-log } \\
\text { cull }\end{array}$ & $\begin{array}{l}\text { Rough and } \\
\text { rotten cull }\end{array}$ & Sawt imber \\
\hline & $--\cdot-$ & housand & c feet- & $---\cdot$ & Doard feet 1 \\
\hline Eastern redcedar & 5,560 & 4,591 & 410 & 559 & 10,871 \\
\hline Bur oak & 74,323 & 60,920 & 6,634 & 6,769 & 286,120 \\
\hline White oak & 2,988 & 2,663 & 243 & 82 & 10,136 \\
\hline Chinkapin oak & 48,354 & 31,458 & 4,632 & 12,264 & 97,247 \\
\hline Post oak & 23,758 & 19,854 & 1,787 & 2,117 & 36,531 \\
\hline Northern red oak & 50,034 & 45,152 & 1,723 & 3,159 & 180,754 \\
\hline Shumard oak & 819 & 676 & & 111 & 2,703 \\
\hline Black oak & 21,214 & 18,536 & 977 & 1,701 & 80,893 \\
\hline Blackjack oak & 4,519 & 2,400 & 1,077 & 1,042 & 3,827 \\
\hline Pin oak & 6,474 & 6,186 & 43 & 245 & 33,378 \\
\hline Shingle oak & 323 & 323 & -- & -- & 567 \\
\hline Shellbark hickory & 1,667 & 1,481 & 90 & 96 & 2,936 \\
\hline Mockernut hickory & 1,752 & 1,401 & $15 b$ & 196 & 5,741 \\
\hline Shagbark hickory & 15,926 & 14,506 & 683 & 737 & 34,370 \\
\hline Bitternut hickory & 12,740 & 11,270 & 883 & 587 & 23,281 \\
\hline Black hickory & 505 & 423 & 51 & 31 & 1,368 \\
\hline Pecan & 10,586 & 8,986 & 757 & 843 & 28,043 \\
\hline Sugar maple & 3,389 & 3,120 & 125 & 144 & 6,280 \\
\hline Silver maple & 24,380 & 21,011 & 1,078 & 2,291 & 87,834 \\
\hline White ash & 2,080 & 1,641 & 188 & 251 & 4,191 \\
\hline Green ash & 72,401 & 60,059 & 5,258 & 7,084 & 181,569 \\
\hline Eastern cottonwood & 145,155 & 134,292 & 4,011 & 6,852 & 610,060 \\
\hline American basswood & 7,565 & 6,031 & 734 & 800 & 25,763 \\
\hline American elm & 41,985 & 25,366 & 5,690 & 10,929 & 59,400 \\
\hline Siberian elm & 1,041 & 343 & 264 & 434 & 271 \\
\hline slippery elm & 9,587 & 4,890 & 2,056 & 2,641 & 9,860 \\
\hline Black walnut & 68,747 & 57,868 & 5,495 & 5,384 & 169,979 \\
\hline Black willow & 15,402 & 11,629 & 821 & 2,952 & 47,901 \\
\hline Boxelder & 22,328 & 10,376 & 3,487 & 8,465 & 22,839 \\
\hline Hackberry & 104,831 & 86,674 & 9,118 & 9,039 & 299,581 \\
\hline American sycamore & 22,924 & 21,538 & 250 & 1,136 & 105,631 \\
\hline Black cherry & 1,936 & 1,250 & 366 & 320 & 3,455 \\
\hline Black locust & 4,357 & 2,636 & 627 & 1,094 & 5,293 \\
\hline Honeyl ocust & 27,648 & 16,555 & 3,739 & 7,354 & 49,897 \\
\hline Kentucky coffeetree & 6,771 & 5,389 & 424 & 958 & 19,474 \\
\hline Northern catalpa & 3,092 & 1,107 & 358 & 1,627 & 2,151 \\
\hline Common persimmon & 1,347 & 1,113 & 24 & 210 & 612 \\
\hline Red mulberry & 19,463 & 6,448 & 3,119 & 9,896 & 11,575 \\
\hline River birch & 818 & 781 & -- & 37 & 2,278 \\
\hline Sugarberry & 399 & 344 & -- & 55 & 1,569 \\
\hline Texas buckeye & 87 & 28 & 20 & 39 & -- \\
\hline All species? I & 889,275 & 711,315 & 67,429 & 110,531 & $2,566,229$ \\
\hline
\end{tabular}

1/International $1 / 4$-inch ru?e.

2/These totals do not include volume for noncommercial species. Volumes for individual noncommercial species are found in Table 47.

Table 47.--Net volume of noncommercial species (nongrowing-stock volume) on commercial forest land by individual species, Kansas, 1981

(In thousand cubic feet)

\begin{tabular}{lc}
\hline Species & $\begin{array}{c}\text { Nongrowing-stock } \\
\text { (rough tree) volume }\end{array}$ \\
\hline Ailanthus & 136 \\
Eastern redbud & 1,329 \\
Hawthorn & 63 \\
Osage-orange & 30,970 \\
Eastern hophornbeam & 800 \\
All species & 33,298 \\
\hline
\end{tabular}


Table 48.--Net volume of growing stock on commercial forest land, by species group and Forest Survey Unit, Kansas, 1981

(In thousand cubic feet)

\begin{tabular}{|c|c|c|c|c|}
\hline & & & t Survey & \\
\hline Species group & $\begin{array}{c}\text { All } \\
\text { Units }\end{array}$ & $\begin{array}{l}\text { North- } \\
\text { eastern } \\
\text { Unit }\end{array}$ & $\begin{array}{l}\text { South- } \\
\text { eastern } \\
\text { Unit }\end{array}$ & $\begin{array}{c}\text { Western } \\
\text { Unit }\end{array}$ \\
\hline SOFTWOODS & & & & \\
\hline Eastern redcedar & 4,591 & 2,446 & 2,112 & 33 \\
\hline Total & 4,591 & 2,446 & 2,112 & 33 \\
\hline HARDWOODS & & & & \\
\hline Bur oak & 60,920 & 29,902 & 15,644 & 15,374 \\
\hline Select white oak & 34,121 & 22,050 & 12,071 & - \\
\hline 0ther white oak & 19,854 & 2,107 & 17,747 & -- \\
\hline Select red oak & 45,828 & 25,577 & 20,251 & -- \\
\hline 0ther red oak & 27,445 & 15,385 & 12,060 & -- \\
\hline Select hickory & 17,388 & 11,801 & 5,587 & -- \\
\hline Other hickory & 11,693 & 6,665 & 5,028 & -- \\
\hline Pecan & 8,986 & 265 & 8,578 & 143 \\
\hline Hard maple & 3,120 & 1,938 & 1,182 & -- \\
\hline Soft maple & 21,011 & 10,459 & 10,552 & -- \\
\hline Ash & 61,700 & 13,845 & 26,734 & 21,121 \\
\hline Cottonwood & 134,292 & 43,561 & 9,786 & 80,945 \\
\hline Basswood & 6,031 & 5,618 & 413 & -- \\
\hline E $1 \mathrm{~m}$ & 30,599 & 13,932 & 12,589 & 4,078 \\
\hline Black walnut & 57,868 & 32,366 & 23,004 & 2,498 \\
\hline Willow & 11,629 & 5,021 & 4,204 & 2,404 \\
\hline Boxelder & 10,376 & 3,563 & 1,831 & 4,982 \\
\hline Hackberry & 86,674 & 37,640 & 38,441 & 10,593 \\
\hline Sycamore & 21,538 & 11,447 & 9,787 & 304 \\
\hline Other hardwoods & 35,651 & 19,505 & 11,527 & 4,619 \\
\hline Total & 706,724 & 312,647 & 247,016 & 147,061 \\
\hline All species & 711,315 & 315,093 & 249,128 & 147,094 \\
\hline
\end{tabular}

Table 49.--Net volume of sawtimber on commercial forest land, by species group and Forest Survey Unit, Kansas, 1981

(In thousand board feet) 1 /

\begin{tabular}{|c|c|c|c|c|}
\hline \multirow[b]{2}{*}{ Species group } & \multirow[b]{2}{*}{$\begin{array}{c}\text { A11 } \\
\text { Units }\end{array}$} & \multicolumn{3}{|c|}{ Forest Survey Unit } \\
\hline & & $\begin{array}{l}\text { North- } \\
\text { eastern } \\
\text { Unit }\end{array}$ & $\begin{array}{l}\text { South- } \\
\text { eastern } \\
\text { Unit }\end{array}$ & $\begin{array}{c}\text { Western } \\
\text { Unit }\end{array}$ \\
\hline \multicolumn{5}{|l|}{ SOFTWOODS } \\
\hline Eastern redcedar & 10,871 & 5,106 & 5,765 & -- \\
\hline Total & 10,871 & 5,106 & 5,765 & - \\
\hline \multicolumn{5}{|l|}{ HARDWOODS } \\
\hline Bur oak & 286,120 & 124,290 & 72,739 & 89,091 \\
\hline Select white oak & 107,383 & 77,476 & 29,907 & - \\
\hline Other white oak & 36,531 & 6,145 & 30,386 & -- \\
\hline Select red oak & 183,457 & 104,284 & 79,173 & -- \\
\hline other red oak & 118,665 & 70,133 & 48,532 & -- \\
\hline Select hickory & 43,047 & 24,060 & 18,987 & -- \\
\hline other hickory & 24,649 & 14,453 & 10,196 & -- \\
\hline Pecan & 28,043 & 575 & 26,708 & 760 \\
\hline Hard maple & 6,280 & 3,635 & 2,645 & - \\
\hline Soft maple & 87,834 & 44,464 & 43,370 & - \\
\hline Ash & 185,760 & 42,154 & 87,049 & 56,557 \\
\hline Cottonwood & $610^{\circ}, 060$ & 196,103 & 39,358 & 374,599 \\
\hline Basswood & 25,763 & 24,807 & 956 & -- \\
\hline$E 7 m$ & 69,531 & 25,507 & 29,537 & 14,487 \\
\hline B lack wal nut & 169,979 & 96,526 & 65,992 & 7,461 \\
\hline Willow & 47,901 & 19,065 & 16,467 & 12,369 \\
\hline Boxelder & 22,839 & 5,924 & 6,077 & 10,838 \\
\hline Hackberry & 299,581 & 112,814 & 137,513 & 49,254 \\
\hline Sycamore & 105,631 & 56,268 & 47,653 & 1,710 \\
\hline Other hardwoods & 96,304 & 53,824 & 29,536 & 12,944 \\
\hline Total & $2,555,358$ & $1,102,507$ & 822,781 & 630,070 \\
\hline All species & $2,566,229$ & $1,107,613$ & 828,546 & 630,070 \\
\hline
\end{tabular}

$1 /$ International $1 / 4$-inch rule. 


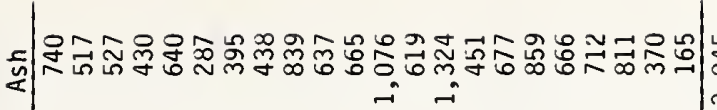

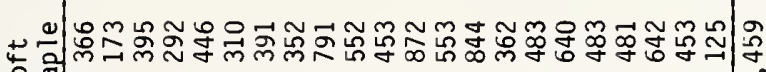

을

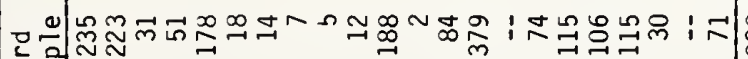
我

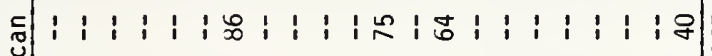
ֻे

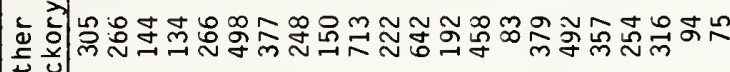
莯

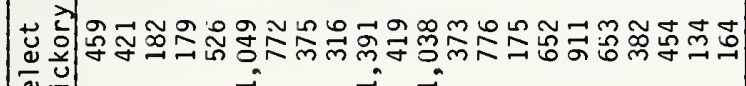
is

은

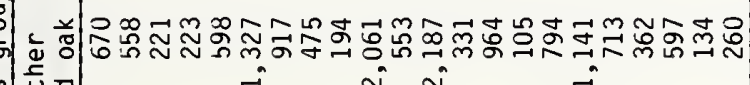

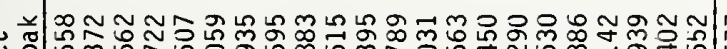

政

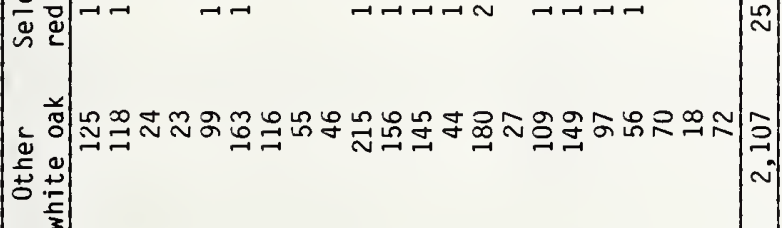

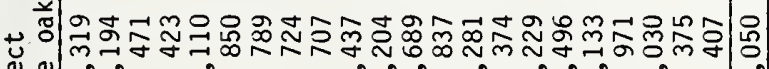

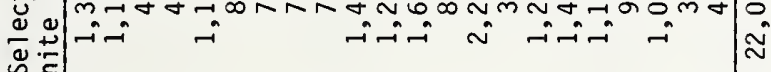
जे $\frac{\pi}{3}$

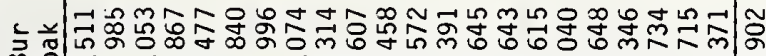

家

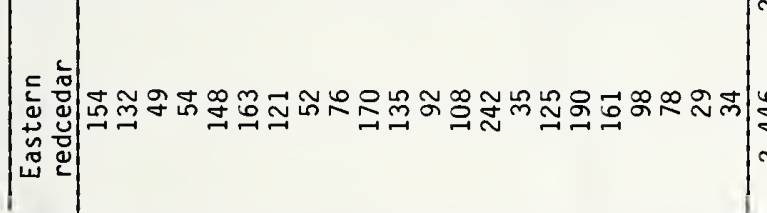

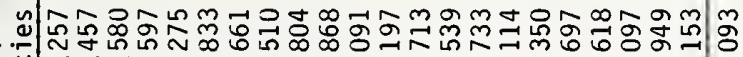

¿

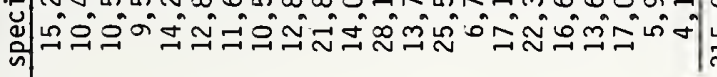

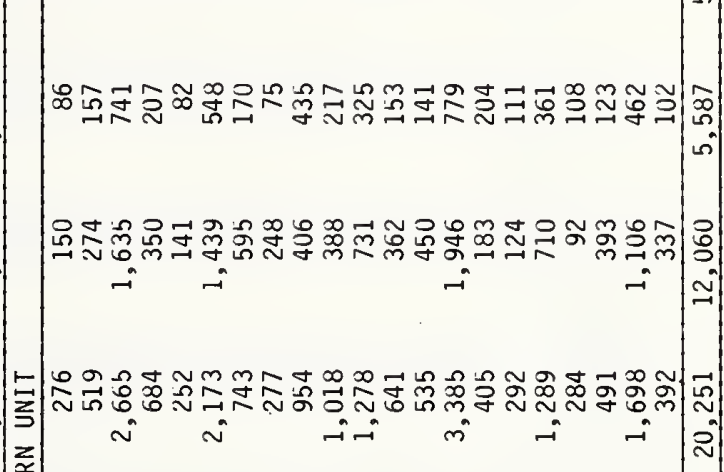

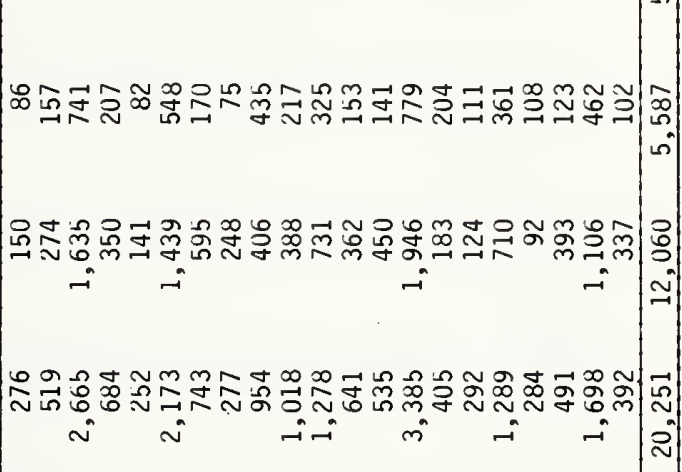

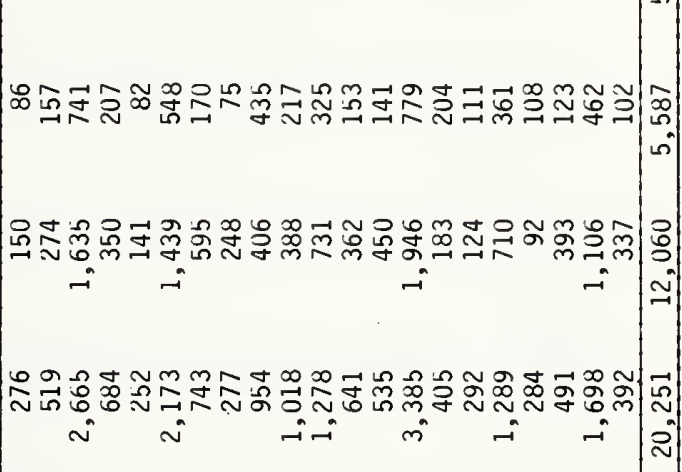

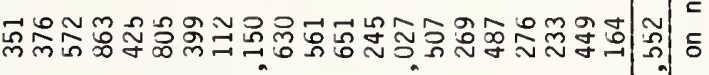

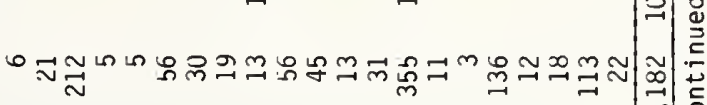

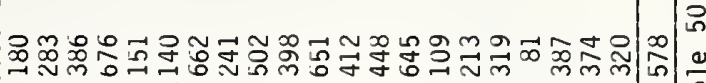

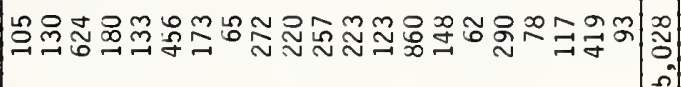

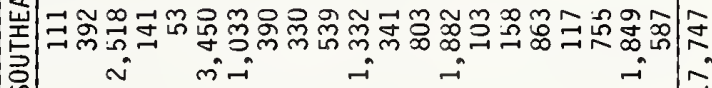

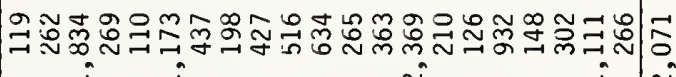

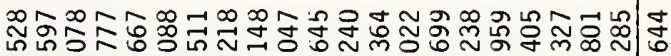
$\rightarrow$ in $\rightarrow+1$ in

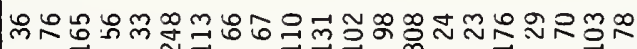

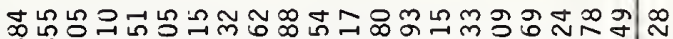

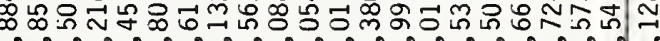

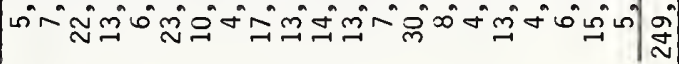

|

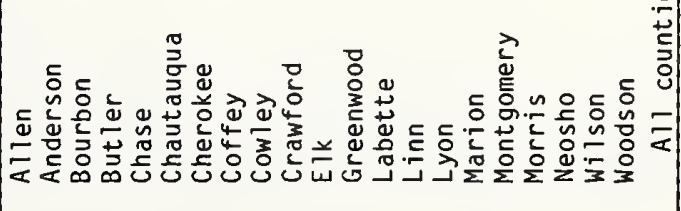




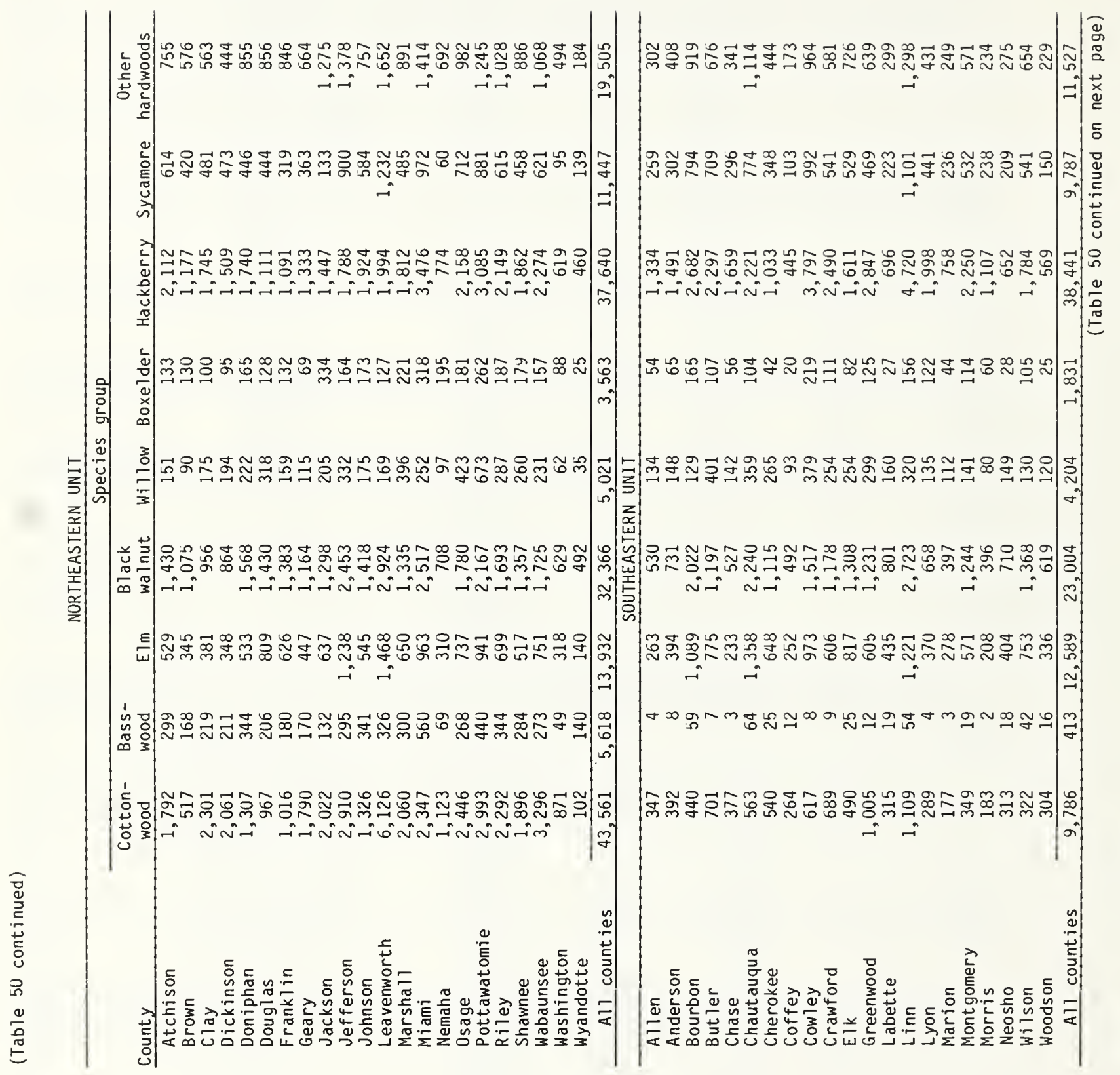




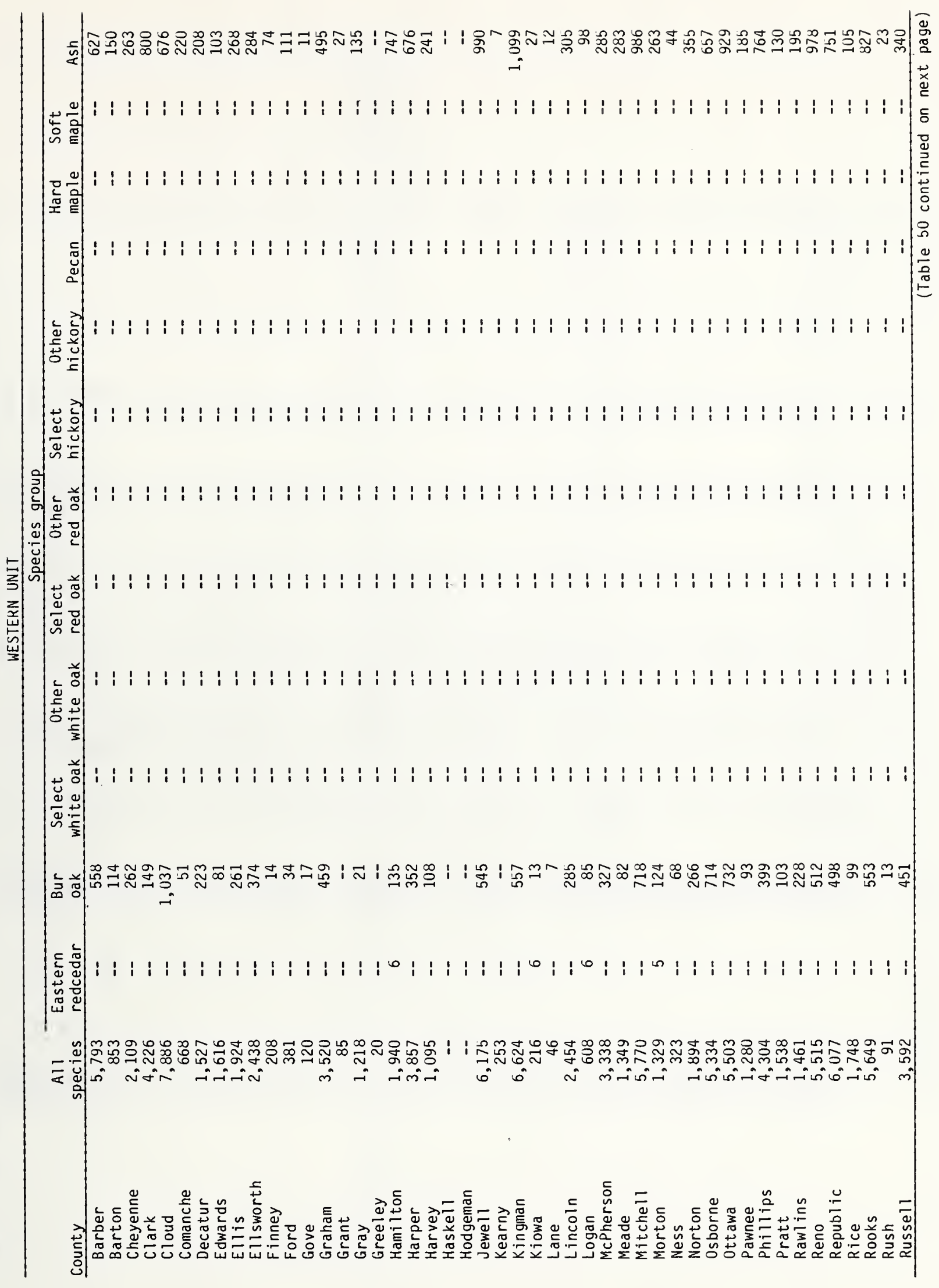




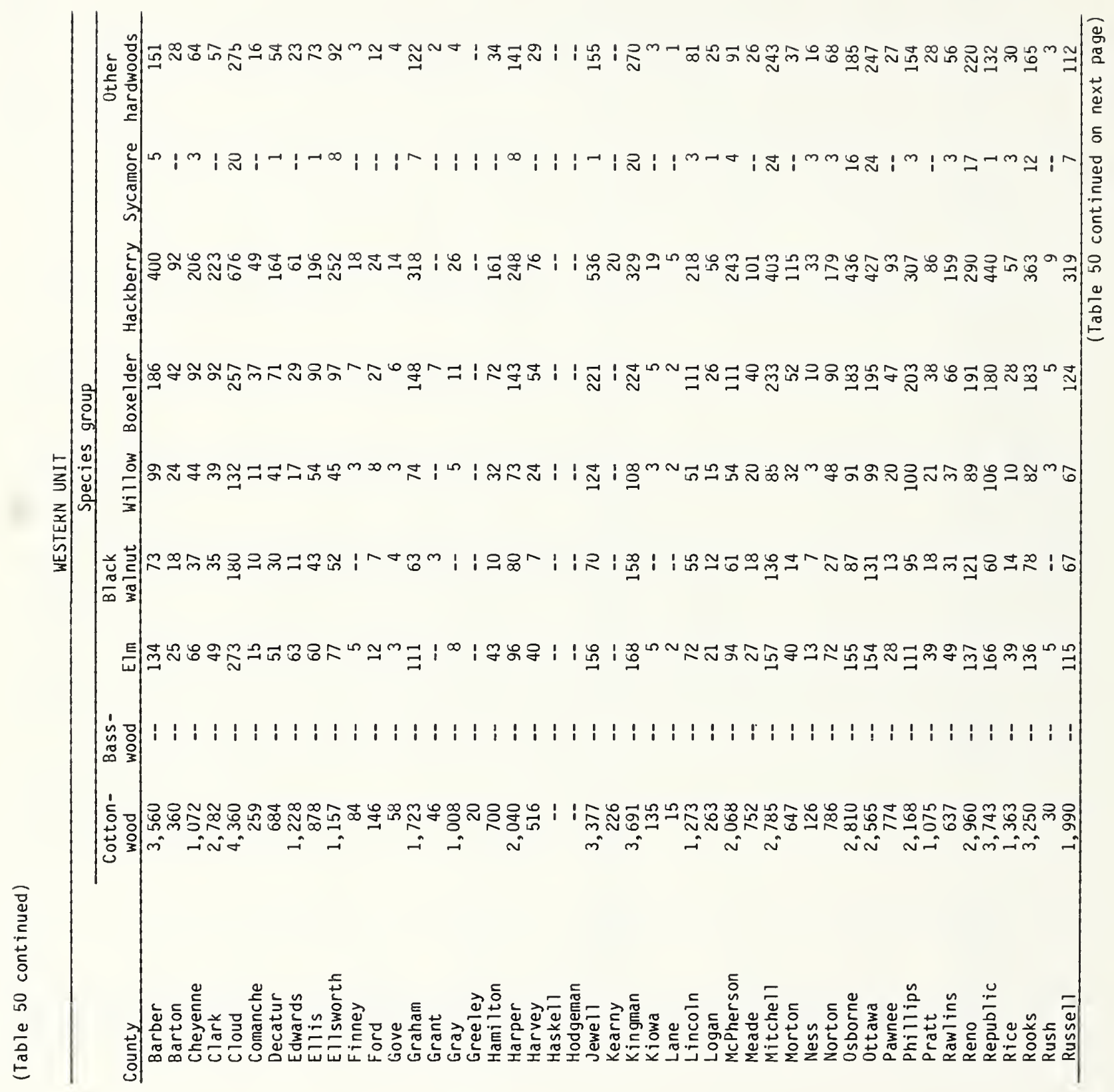



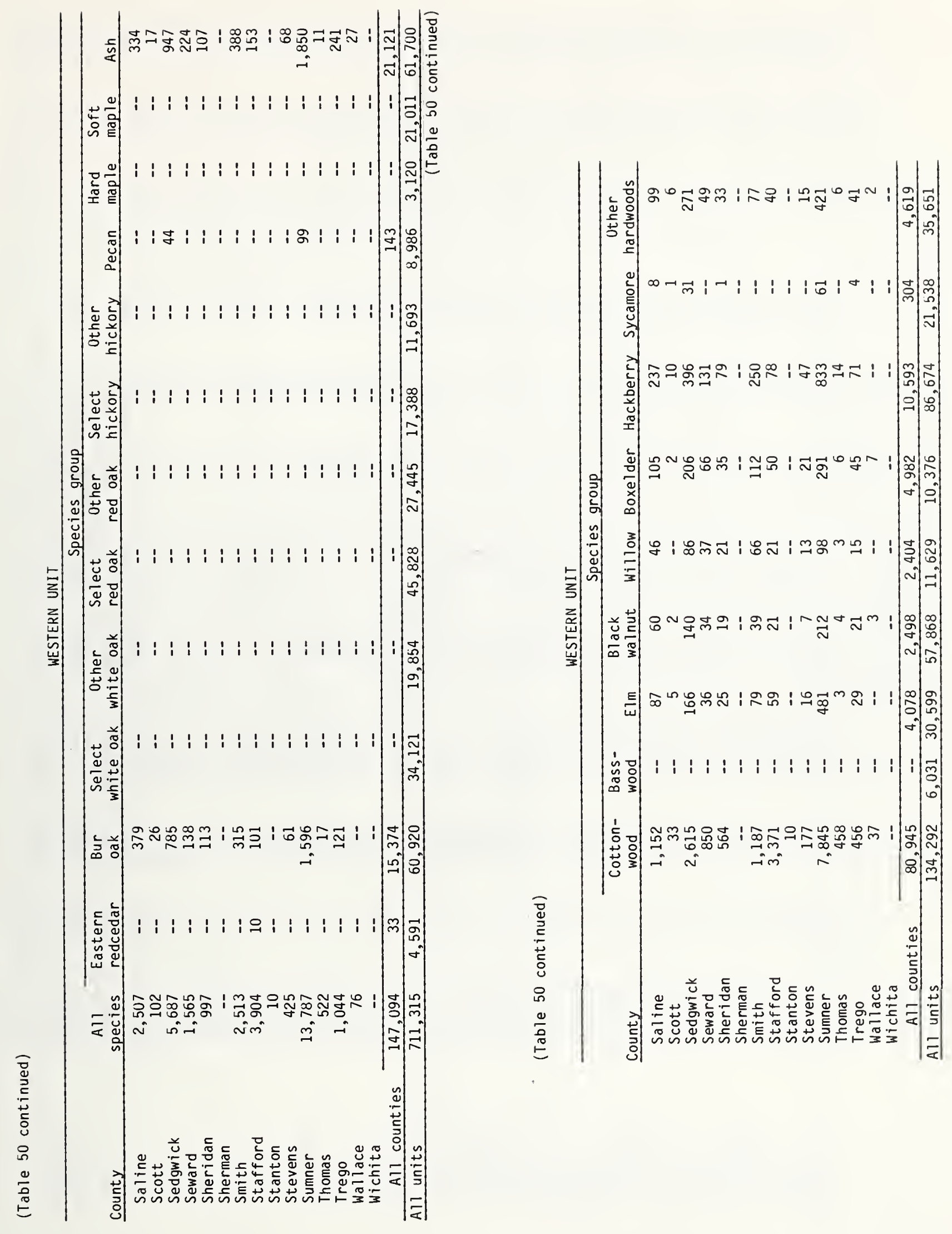


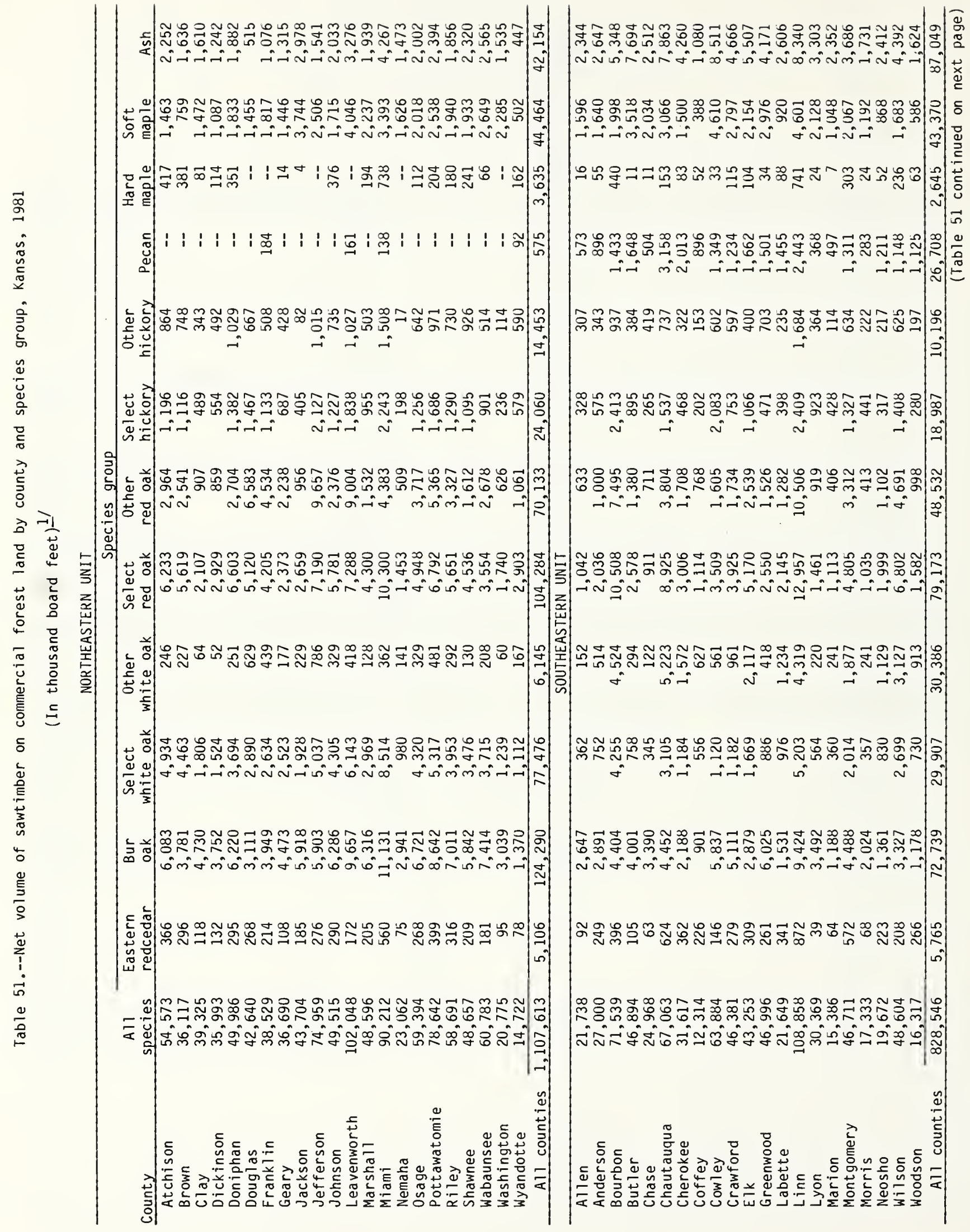

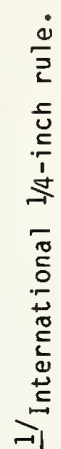




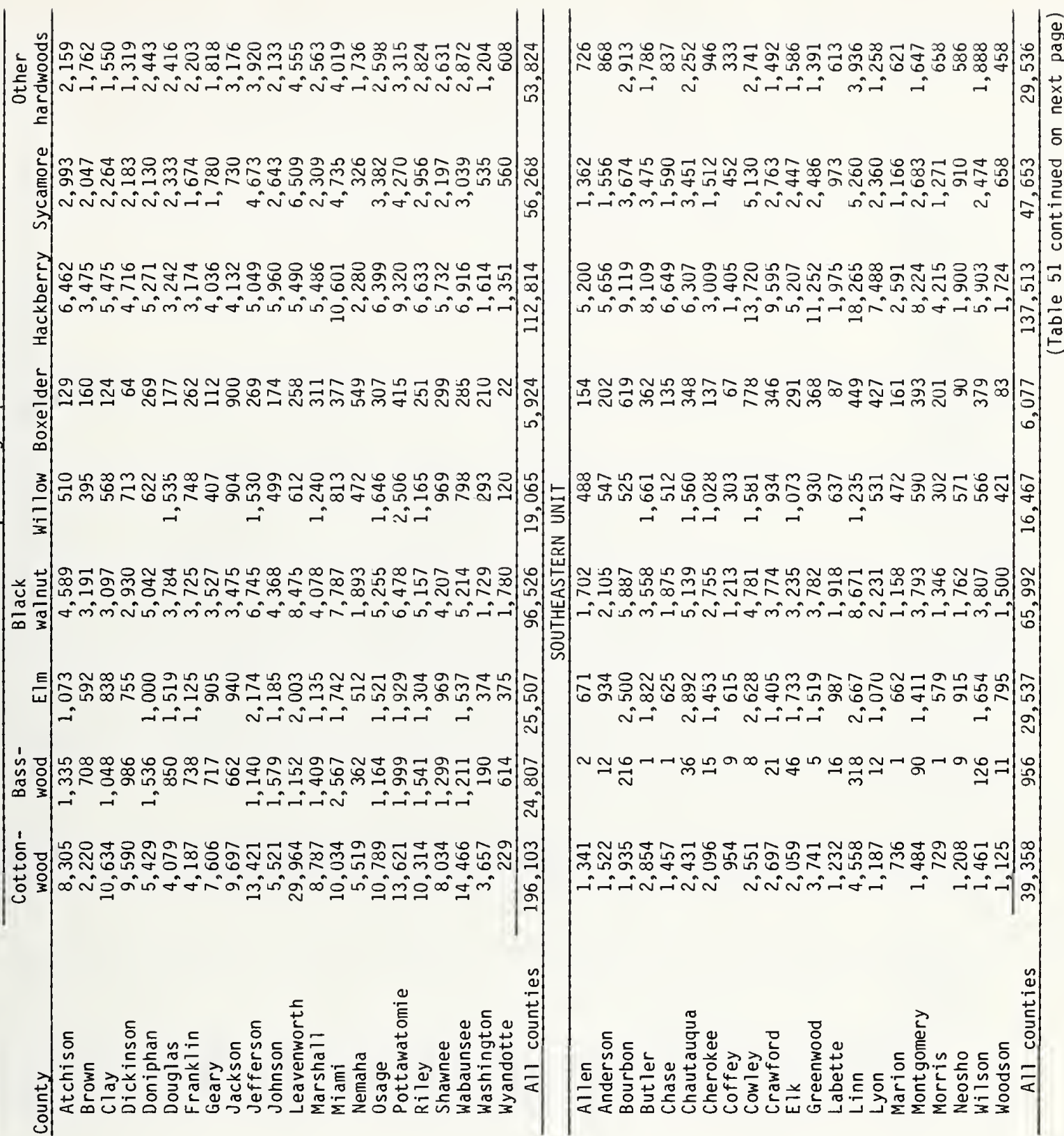




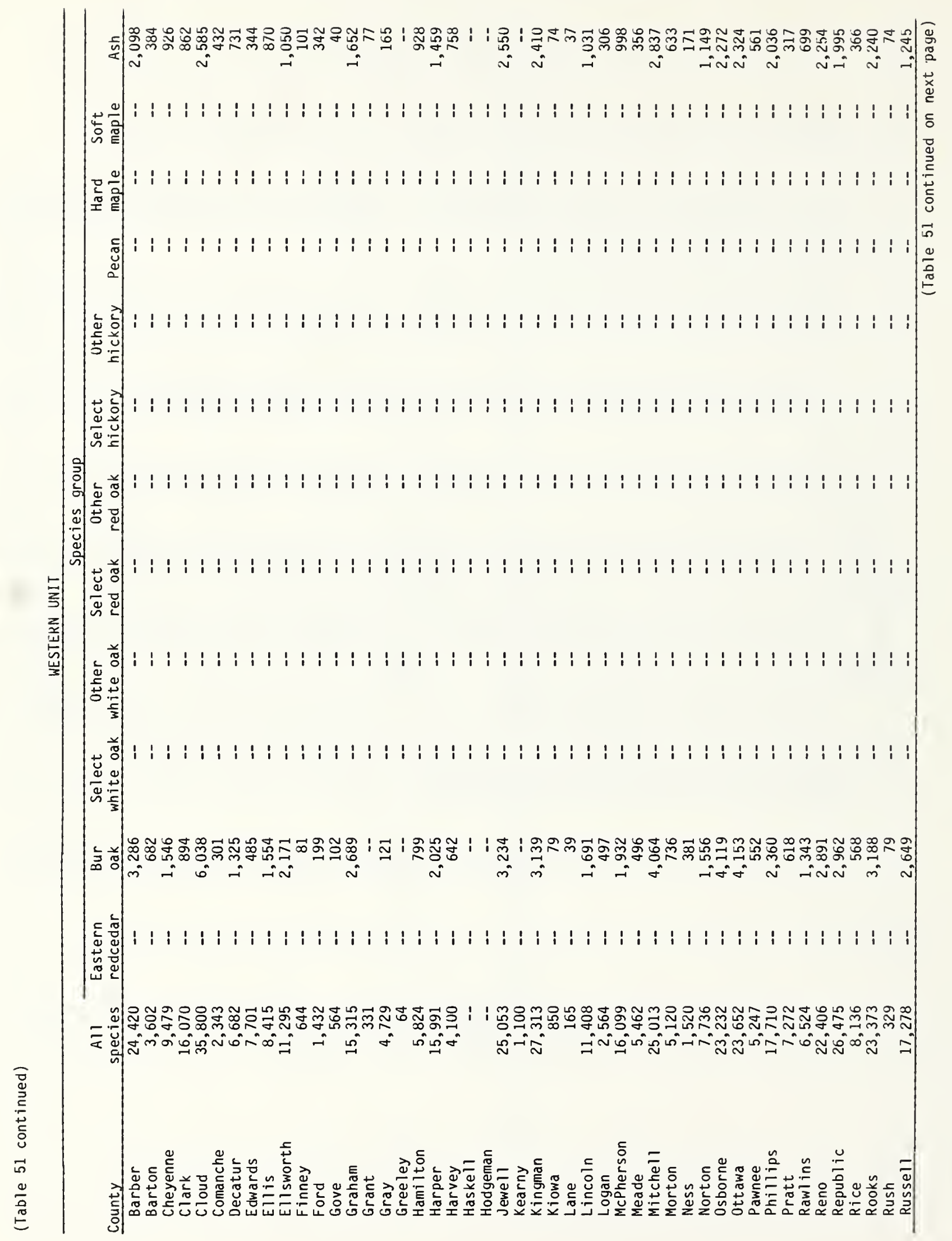




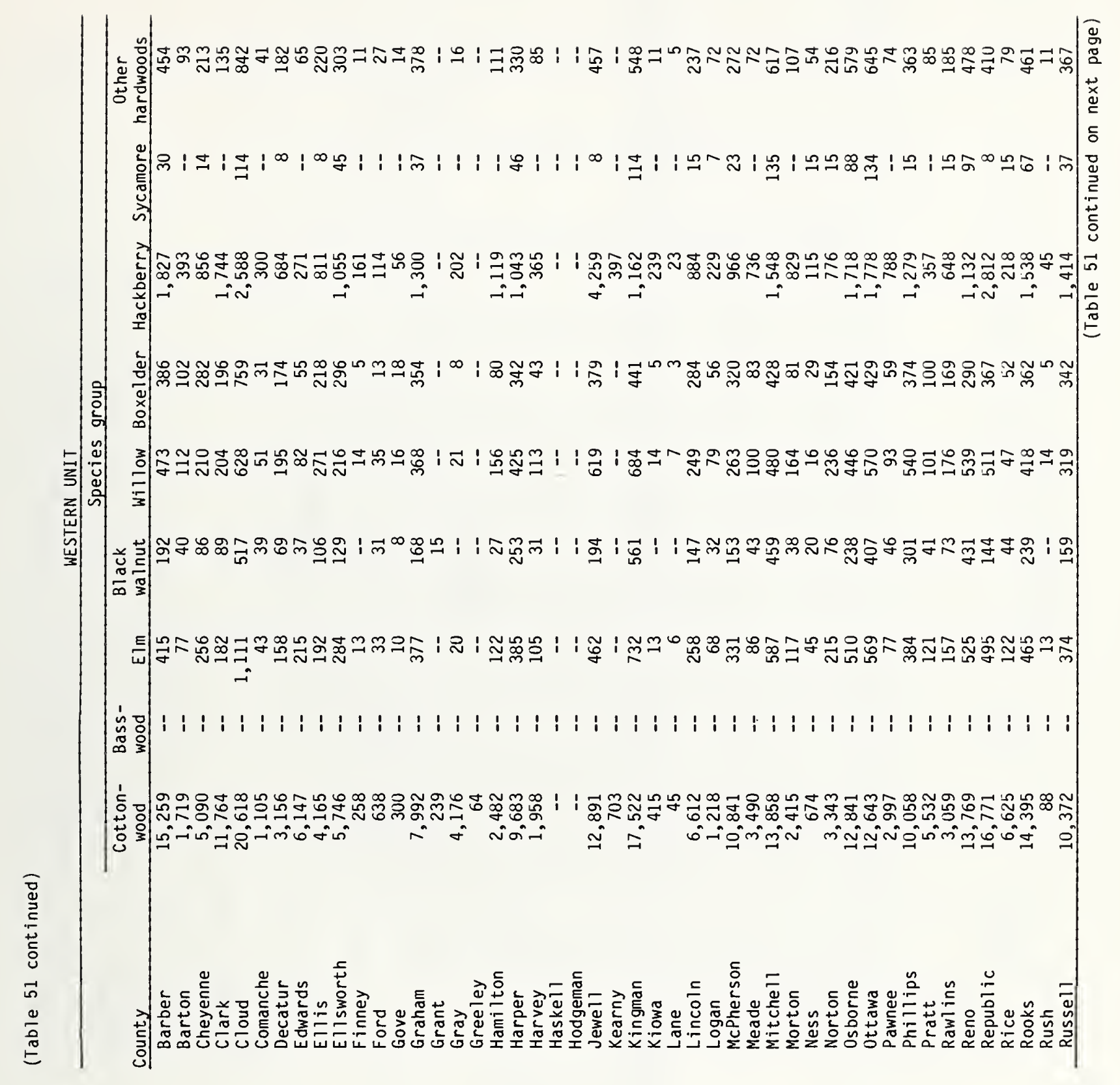




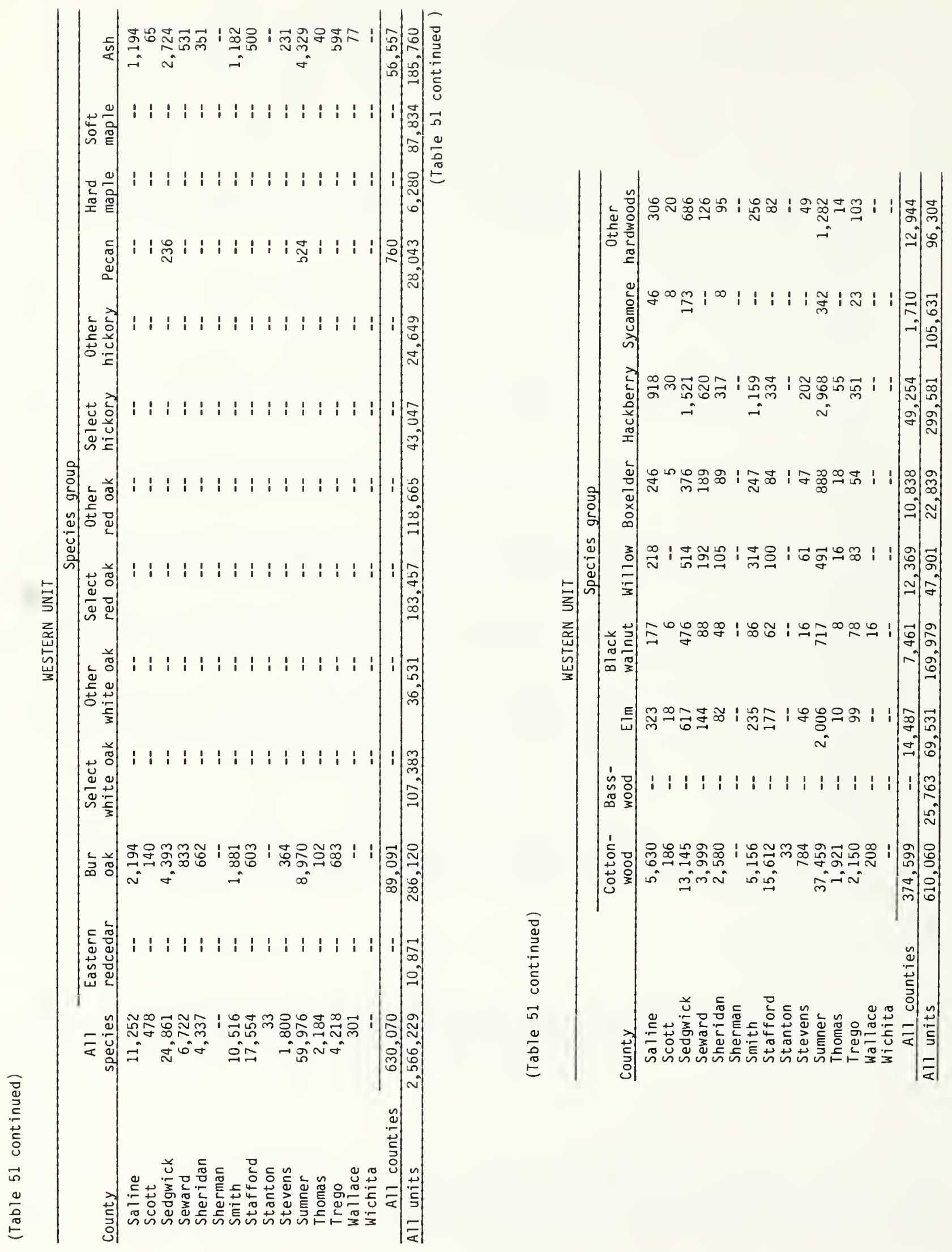




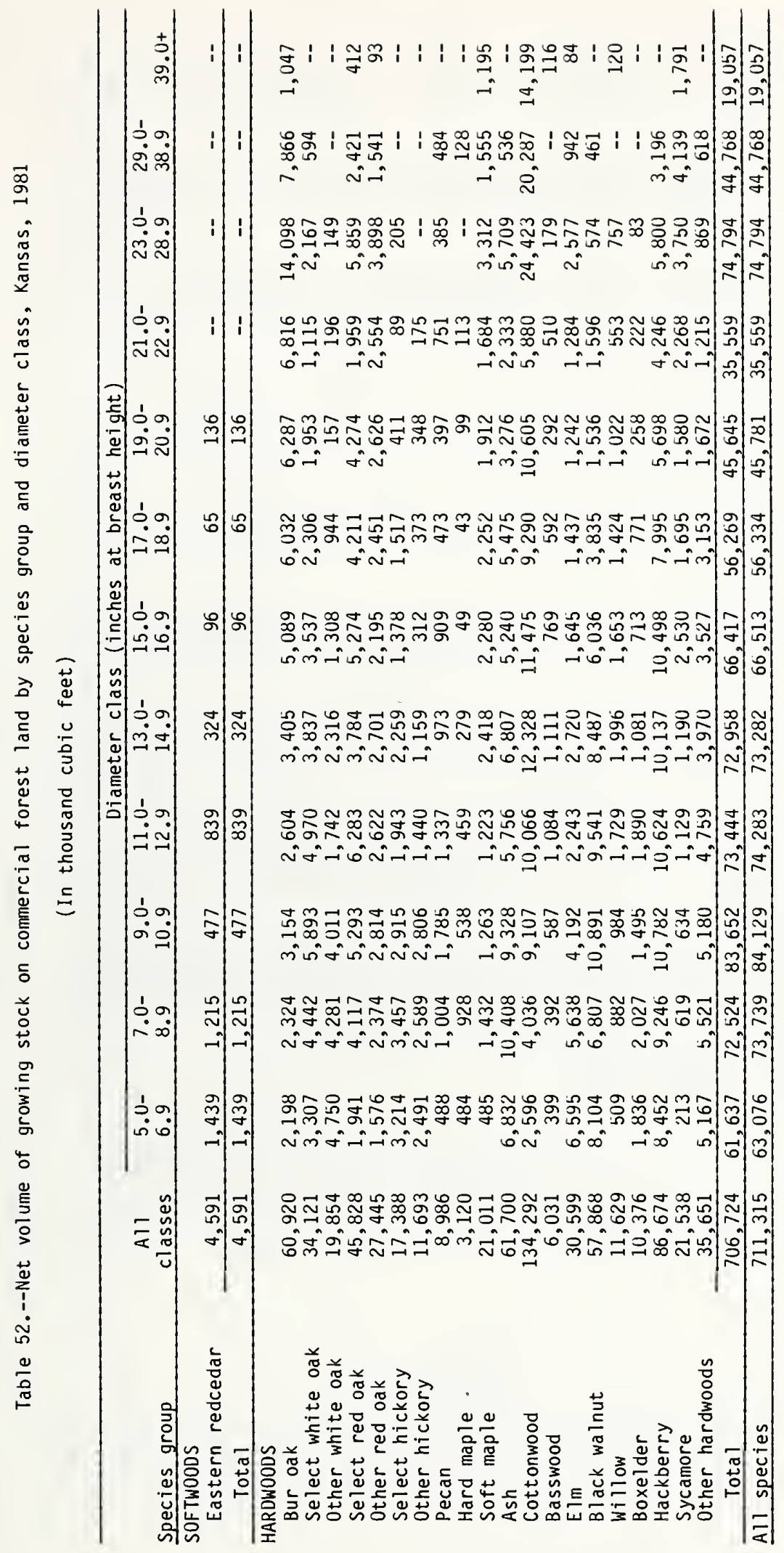




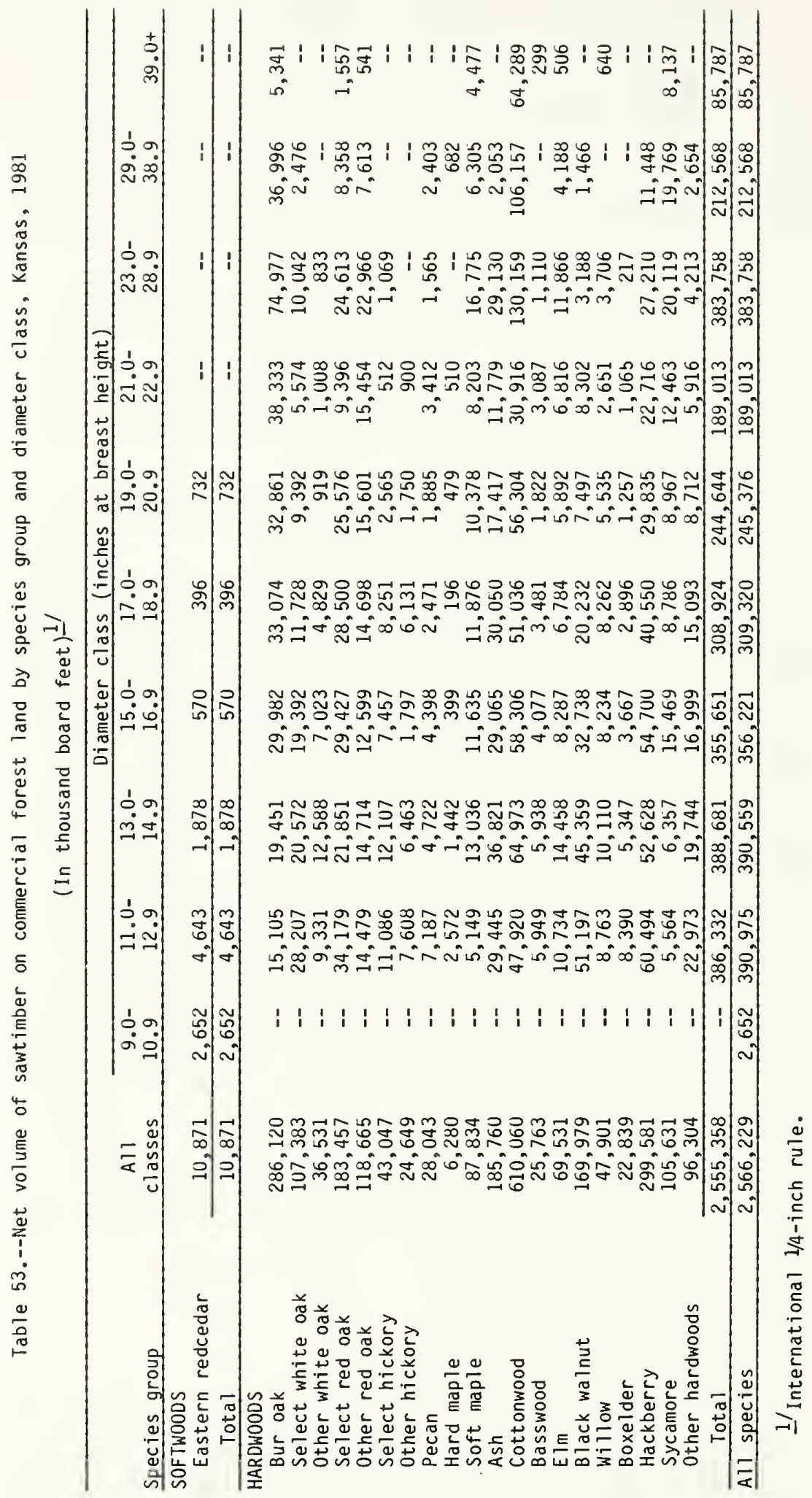




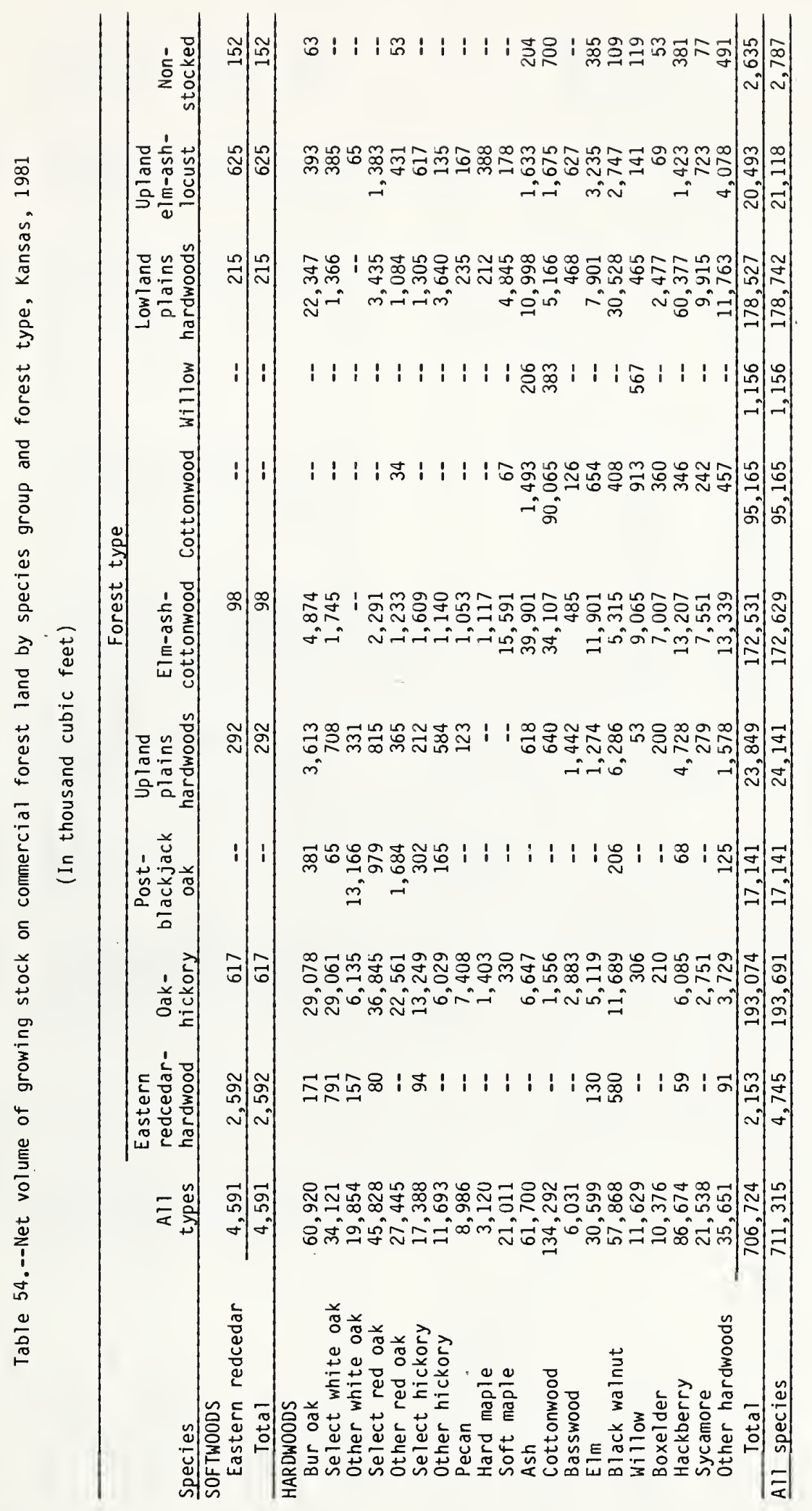




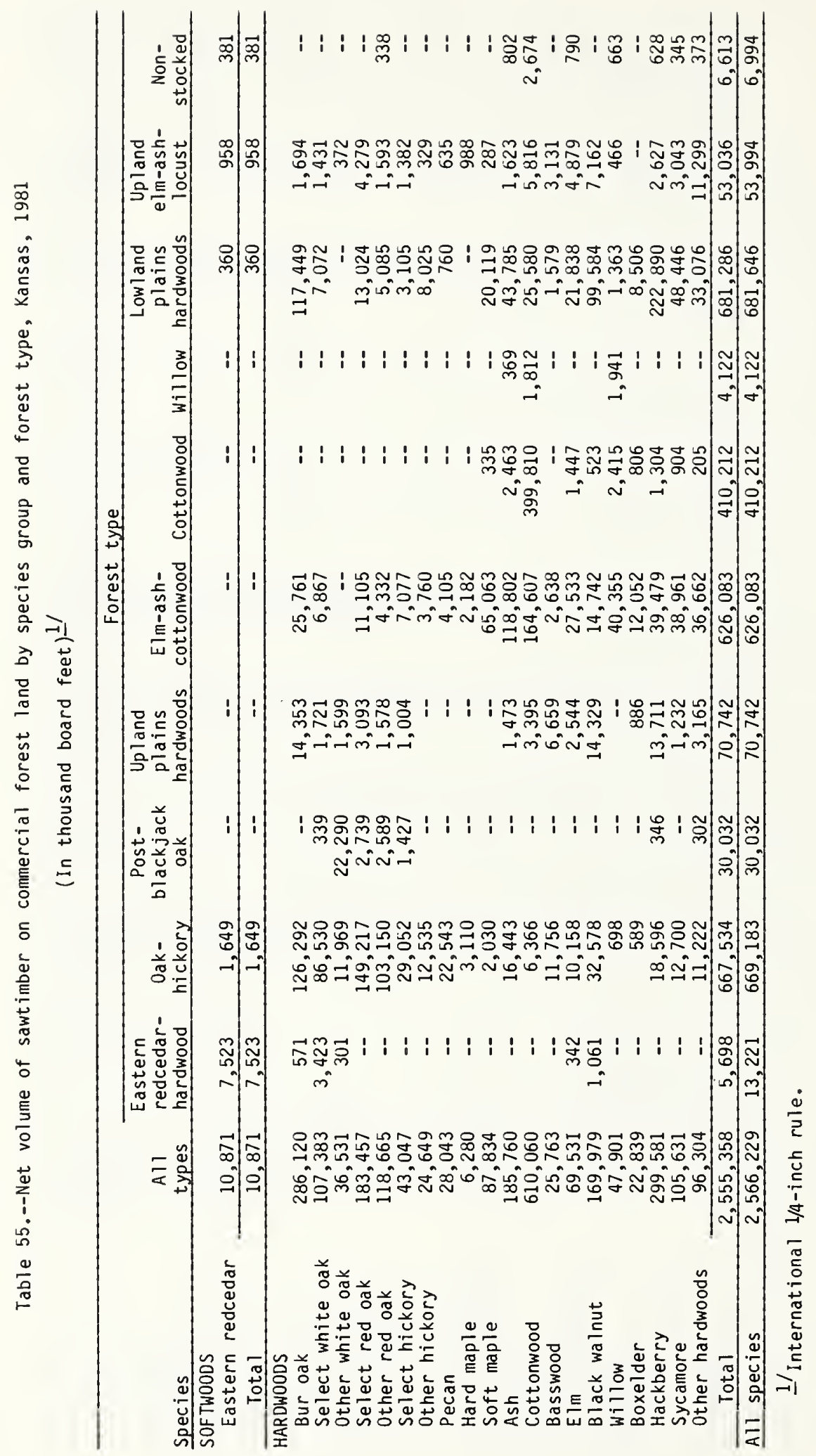


Table 56.--Net volume of growing stock on commercial forest land by species group and ownership class, Kansas, 1981

(In thousand cubic feet)

\begin{tabular}{|c|c|c|c|c|c|c|c|c|}
\hline \multirow[b]{2}{*}{ Species group } & \multirow[b]{2}{*}{$\begin{array}{c}\text { A11 } \\
\text { classes }\end{array}$} & \multicolumn{7}{|c|}{ Ownership class } \\
\hline & & $\begin{array}{c}\text { National } \\
\text { forest }\end{array}$ & $\begin{array}{c}\text { Misc. } \\
\text { federal }\end{array}$ & Indian & State & $\begin{array}{c}\text { County and } \\
\text { municipal }\end{array}$ & Farmer & $\begin{array}{l}\text { Misc. } \\
\text { private }\end{array}$ \\
\hline \multicolumn{9}{|l|}{ SOFTWOODS } \\
\hline Eastern redcedar & 4,591 & -- & 52 & $\because$ & -- & -- & 3,289 & 1,250 \\
\hline Total & 4,591 & $=$ & 52 & $=$ & -- & -- & 3,289 & 1,250 \\
\hline \multicolumn{9}{|l|}{ HARDWOODS } \\
\hline Bur oak & 60,920 & - & 1,237 & - & 282 & - & 38,563 & 20,838 \\
\hline Select white oak & 34,121 & -- & 978 & -- & -- & 200 & 18,816 & 14,127 \\
\hline Other white oak & 19,854 & -- & 731 & -- & -- & -- & 14,227 & 4,896 \\
\hline Select red oak & 45,828 & -- & 1,049 & -- & -- & -- & 27,348 & 17,431 \\
\hline Other red oak & 27,445 & -- & 123 & -- & 3,041 & -- & 15,875 & 8,406 \\
\hline Select hickory & 17,388 & -- & 616 & -- & 114 & - & 8,230 & 8,428 \\
\hline 0ther hickory & 11,693 & - & 450 & -- & - & -- & 6,696 & 4,547 \\
\hline Pecan & 8,986 & -- & -- & -- & 91 & -- & 3,444 & 5,451 \\
\hline Hard maple & 3,120 & -- & -- & -- & -- & -- & 737 & 2,383 \\
\hline Soft maple & 21,011 & -- & 749 & -- & 1,566 & 659 & 11,177 & 6,860 \\
\hline Ash & 61,700 & -- & 1,523 & - & 941 & - & 40,475 & 18,761 \\
\hline Cottonwood & 134,292 & - & 9,794 & 398 & 2,130 & -- & 73,053 & 48,917 \\
\hline Basswood & 6,031 & -- & 98 & - & - & - & 3,943 & 1,990 \\
\hline Elm & 30,599 & -- & 1,192 & 58 & 139 & 130 & 17,944 & 11,136 \\
\hline Black walnut & 57,868 & -- & 2,229 & - & 66 & 223 & 36,723 & 18,627 \\
\hline Willow & $11,62 y$ & -- & 232 & -- & 32 & 443 & 7,763 & 3,159 \\
\hline Boxelder & 10,376 & -- & 95 & - & - & 200 & 7,379 & 2,702 \\
\hline Hackberry & 86,674 & -- & 3,628 & 180 & 92 & 990 & 55,798 & 25,986 \\
\hline Sycamore & 21,538 & -- & 1,608 & - & - & - & 15,703 & 4,227 \\
\hline other hardwoods & 35,651 & - & 1,520 & 398 & 246 & 432 & 19,981 & 13,074 \\
\hline Total & 706,724 & -- & 27,852 & 1,034 & 8,740 & 3,277 & 423,875 & 241,946 \\
\hline A11 species & 711,315 & - & 27,904 & 1,034 & 8,740 & 3,277 & 427,164 & 243,196 \\
\hline
\end{tabular}

Table 57.--Net volume of sawtimber on commercial forest land by species group and ownership class, Kansas, 1981

(In thousand board feet) 1 '

\begin{tabular}{|c|c|c|c|c|c|c|c|c|}
\hline \multirow[b]{2}{*}{ Species group } & \multirow[b]{2}{*}{$\begin{array}{c}\text { All } \\
\text { classes } \\
\end{array}$} & \multicolumn{7}{|c|}{ Ownership class } \\
\hline & & $\begin{array}{c}\text { National } \\
\text { forest }\end{array}$ & $\begin{array}{c}\text { Misc. } \\
\text { federal }\end{array}$ & Indian & State & $\begin{array}{l}\text { County and } \\
\text { municipal }\end{array}$ & Farmer & $\begin{array}{c}\text { Misc. } \\
\text { private }\end{array}$ \\
\hline \multicolumn{9}{|l|}{ SOFTWOODS } \\
\hline Eastern redcedar & 10,871 & $=$ & $=$ & $\because$ & - & - & 9,115 & 1,756 \\
\hline Total & 10,871 & - & -- & -- & -- & -- & 9,115 & 1,756 \\
\hline \multicolumn{9}{|l|}{ HARDWOODS } \\
\hline Bur oak & 286,120 & -- & 5,909 & - & 1,271 & - & 180,540 & 98,400 \\
\hline Select white oak & 107,383 & -- & 3,014 & -- & -- & -- & 65,965 & 38,404 \\
\hline Other white oak & 36,531 & -- & 1,902 & - & - & -- & 25,810 & 8,819 \\
\hline Select red oak & 183,457 & -- & 4,751 & -- & -- & -- & 105,393 & 73,313 \\
\hline Other red oak & 118,665 & - & -- & -- & 18,519 & -- & 69,966 & 30,180 \\
\hline Select hickory & 43,047 & -- & 425 & -- & 286 & -- & 21,144 & 21,192 \\
\hline Other hickory & 24,649 & -- & -- & -- & -- & -- & 14,218 & 10,431 \\
\hline Pecan & 28,043 & -- & -- & -- & 541 & -- & 12,991 & 14,511 \\
\hline Hard maple & 6,280 & -- & -- & - & - & -- & 1,617 & 4,663 \\
\hline Soft maple & 87,834 & -- & 2,936 & -- & 8,597 & 2,004 & 44,993 & 29,304 \\
\hline Ash & 185,760 & -- & 4,073 & - & 4,798 & -- & 118,314 & 58,575 \\
\hline Cottonwood & 610,060 & -- & 55,081 & 862 & -- & -- & 336,232 & 217,885 \\
\hline Basswood & 25,763 & -- & 487 & -- & -- & -- & 17,069 & 8,207 \\
\hline E $1 \mathrm{~m}$ & 69,531 & -- & 2,022 & -- & -- & 628 & 43,595 & 23,286 \\
\hline Black walnut & 169,979 & -- & 9,998 & -- & 342 & 628 & 107,965 & 51,046 \\
\hline Willow & 47,901 & -- & 831 & -- & -- & 2,064 & 31,674 & 13,332 \\
\hline Boxelder & 22,839 & -- & -- & -- & -- & 886 & 16,780 & 5,173 \\
\hline Hackberry & 299,581 & -- & 9,875 & 315 & 471 & 2,492 & 192,875 & 93,553 \\
\hline Sycamore & 105,631 & -- & 9,068 & -- & -- & -- & 77,423 & 19,140 \\
\hline Other hardwoods & 96,304 & -- & 5,351 & 1,513 & 1,591 & 1,970 & 49,455 & 36,424 \\
\hline Total & $2,555,358$ & -- & 115,723 & 2,690 & 36,416 & 10,672 & $1,534,019$ & 855,838 \\
\hline A11 species & $2,566,229$ & -- & 115,723 & 2,690 & 36,416 & 10,672 & $1,543,134$ & 857,594 \\
\hline
\end{tabular}

1/International $1 / 4$-inch rule. 

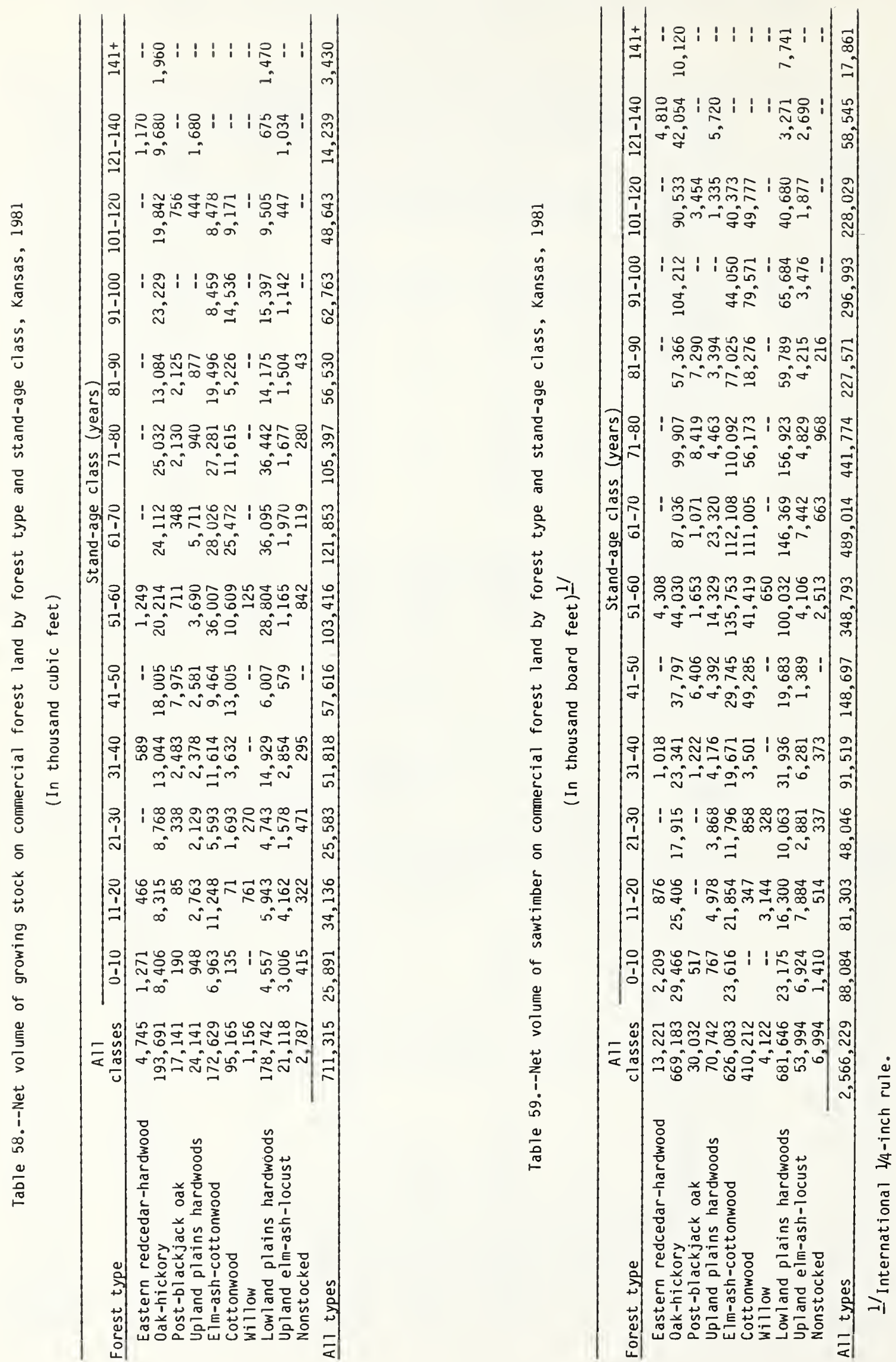


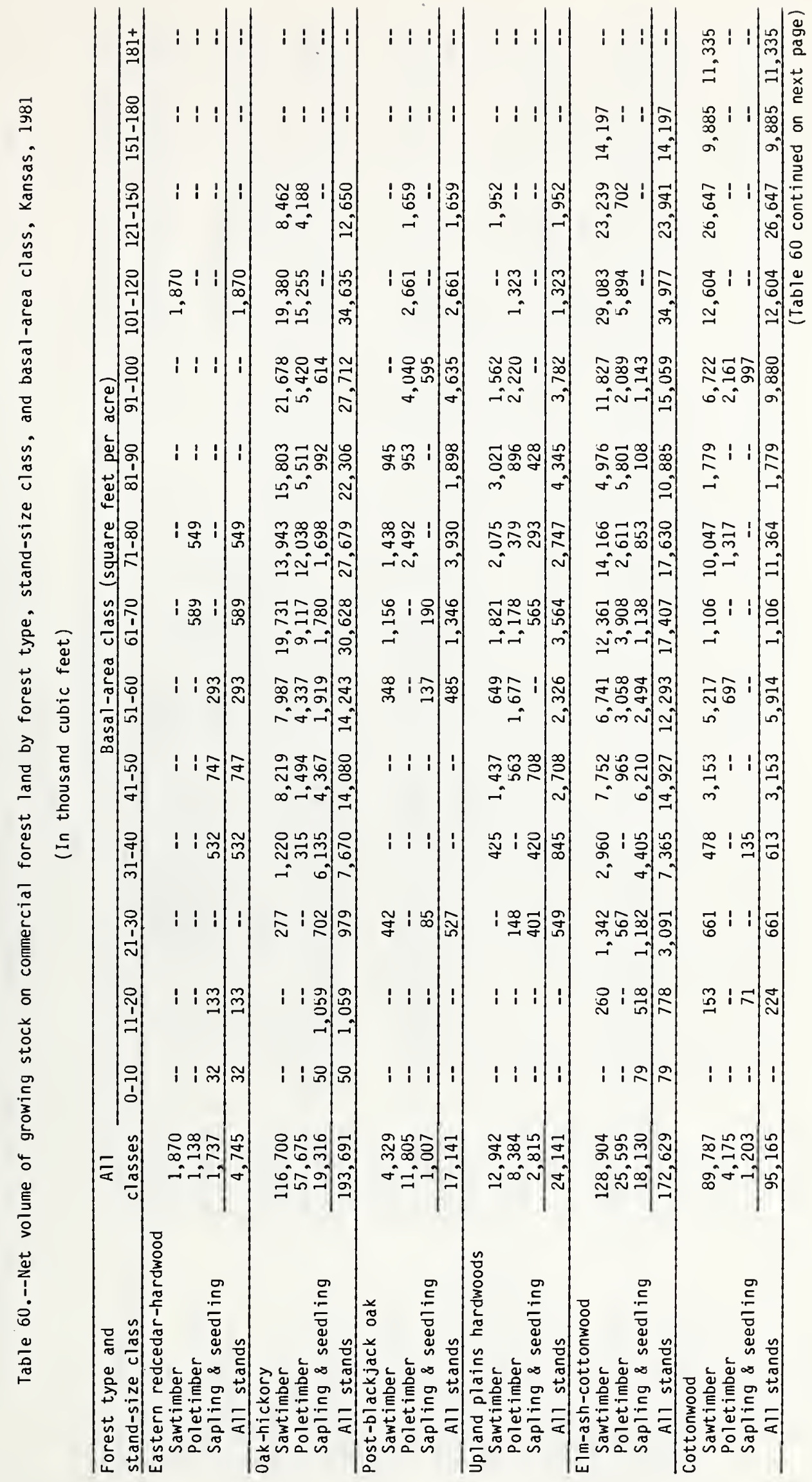




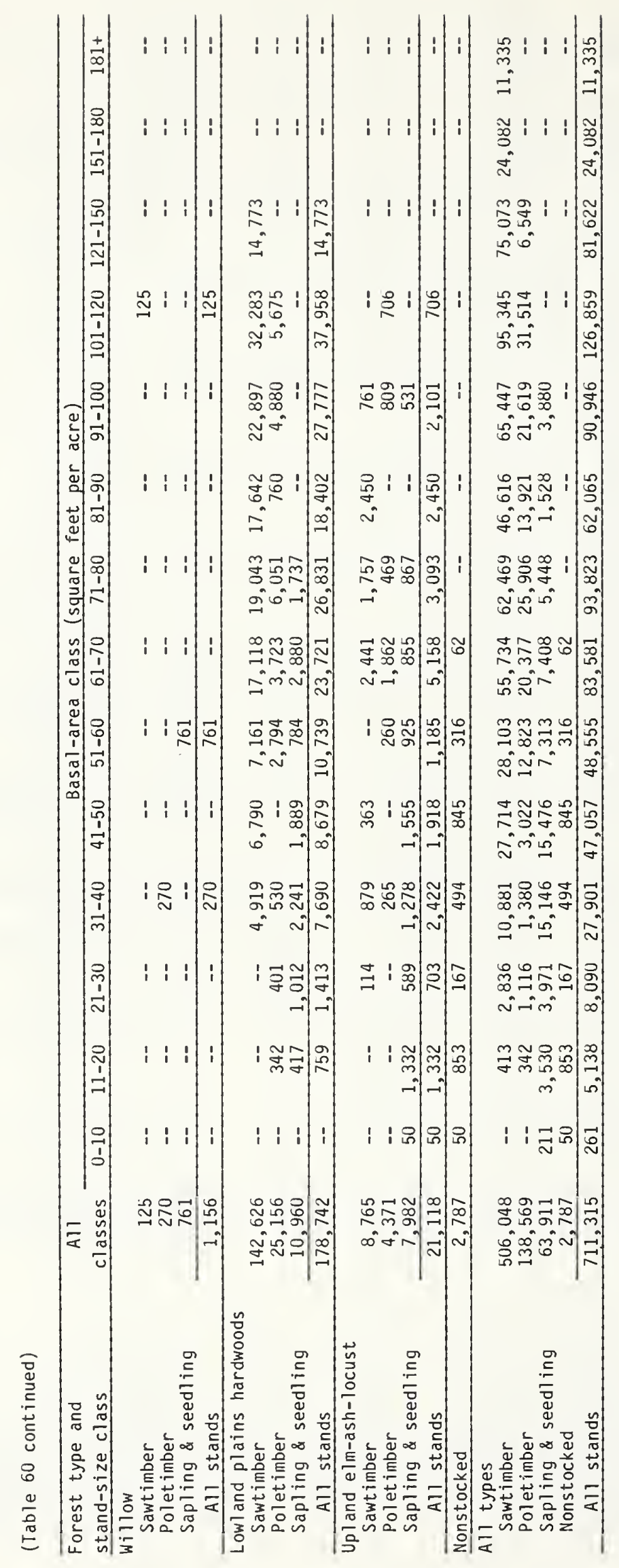




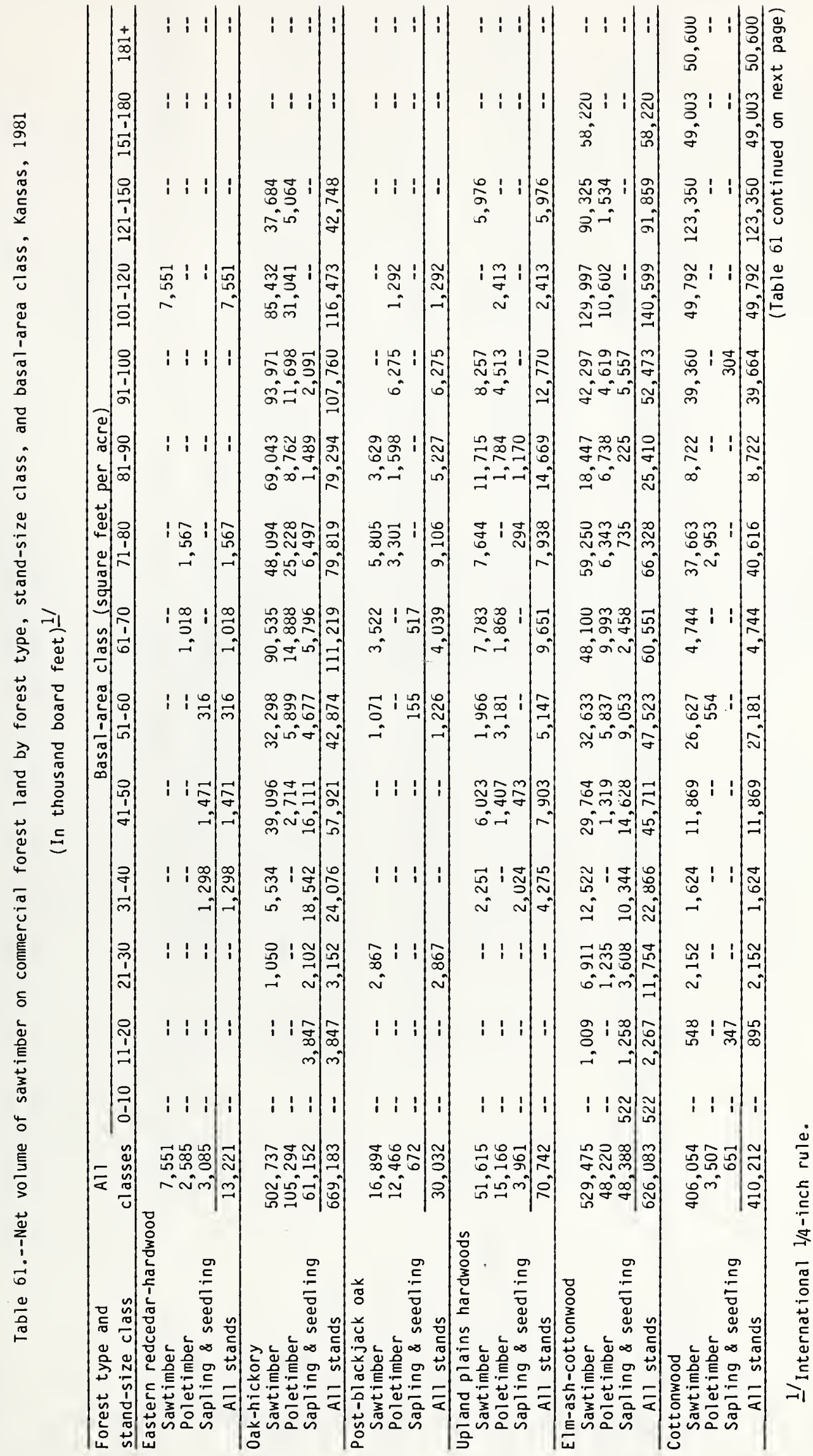




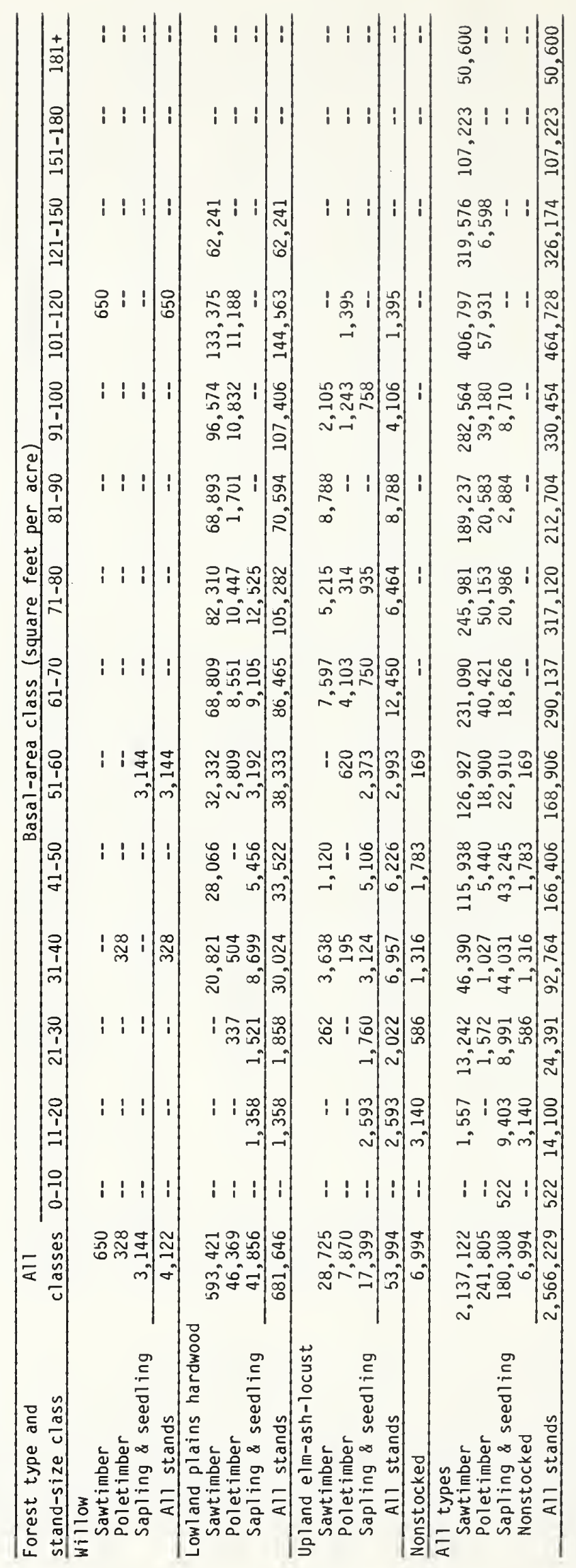


Table 62.--Net volume of sawtimber on commercial forest land by species group and butt log-grade, Kansas, 1981

(In thousand board feet) 1 /

\begin{tabular}{|c|c|c|c|c|c|}
\hline \multirow[b]{2}{*}{ Species group } & \multirow{2}{*}{$\begin{array}{l}\text { All } \\
\text { grades }\end{array}$} & \multicolumn{4}{|c|}{ Log grade } \\
\hline & & 1 & 2 & 3 & Tie and timber \\
\hline \multicolumn{6}{|l|}{ SOFTWO0DS } \\
\hline Total & 10,871 & -- & -- & 9,288 & 1,583 \\
\hline \multicolumn{6}{|l|}{ HARDWOODS } \\
\hline Bur oak & 286,120 & 62,314 & 83,866 & 125,690 & 14,250 \\
\hline Select white oak & 107,383 & 15,773 & 31,101 & 57,630 & 2,879 \\
\hline Other white oak & 36,531 & 1,511 & 11,996 & 22,451 & 573 \\
\hline Select red oak & 183,457 & 42,611 & 58,851 & 77,067 & 4,928 \\
\hline other red oak & 118,665 & 16,741 & 40,147 & 52,680 & 9,097 \\
\hline Select hickory & 43,047 & 7,461 & 16,724 & 17,213 & 1,649 \\
\hline Other hickory & 24,649 & 3,698 & 11,719 & 8,127 & 1,105 \\
\hline Pecan & 28,043 & 11,015 & 6,254 & 10,774 & -- \\
\hline Hard maple & 6,280 & 1,141 & 1,889 & 2,698 & 552 \\
\hline Soft maple & 87,834 & 19,380 & 28,931 & 35,865 & 3,658 \\
\hline Ash & 185,760 & 68,512 & 61,858 & 53,810 & 1,580 \\
\hline Cottonwood & 610,060 & 326,242 & 136,913 & 136,314 & 10,591 \\
\hline Basswood & 25,763 & 8,822 & 3,602 & 12,284 & 1,055 \\
\hline Elm & 69,531 & 8,683 & 10,404 & 46,889 & 3,555 \\
\hline Black walnut & 169,979 & 40,924 & 66,343 & 61,521 & 1,191 \\
\hline Willow & 47,901 & 17,421 & 13,992 & 14,031 & 2,457 \\
\hline Boxelder & 22,839 & -- & 5,456 & 15,893 & 1,490 \\
\hline Hackberry & 299,581 & 89,384 & 96,672 & 103,430 & 10,095 \\
\hline Sycamore & 105,631 & 60,261 & 30,246 & 14,175 & 949 \\
\hline Other hardwoods & 96,304 & 7,671 & 30,719 & 53,286 & 4,628 \\
\hline Total & $2,555,358$ & 809,565 & 747,683 & 921,828 & 76,282 \\
\hline All species & $2,566,229$ & 809,565 & 747,683 & 931,116 & 77,865 \\
\hline
\end{tabular}

1 International $1 / 4$-inch rule. 
Table 63.--Net volume of growing-stock trees by forest type and ground land use, Kansas, 1981

(In thousand cubic feet)

\begin{tabular}{|c|c|c|c|c|c|}
\hline \multirow[b]{2}{*}{ Forest type } & \multicolumn{5}{|c|}{ Ground land use } \\
\hline & $\begin{array}{c}\text { Pastured } \\
\text { commercial forest }\end{array}$ & $\begin{array}{c}\text { Unpastured } \\
\text { commercial forest }\end{array}$ & $\begin{array}{l}\text { Wooded } \\
\text { strips }\end{array}$ & Windbreaks & $\begin{array}{l}\text { Wooded } \\
\text { pasture }\end{array}$ \\
\hline $\begin{array}{l}\text { Eastern redcedar-hardwood } \\
\text { Oak-hickory } \\
\text { Post-blackjack oak } \\
\text { Upland plains hardwoods } \\
\text { Elm-ash-cottonwood } \\
\text { Cottonwood } \\
\text { Willow } \\
\text { Lowland plains hardwoods } \\
\text { Upland elm-ash-locust } \\
\text { Nonstocked }\end{array}$ & $\begin{array}{r}1,262 \\
48,040 \\
6,669 \\
9,108 \\
27,954 \\
25,286 \\
-- \\
33,580 \\
8,071 \\
1,421 \\
\end{array}$ & $\begin{array}{r}3,483 \\
145,651 \\
10,472 \\
15,033 \\
144,675 \\
69,879 \\
1,156 \\
145,162 \\
13,047 \\
1,366 \\
\end{array}$ & $\begin{array}{r}16,881 \\
2,309 \\
-- \\
1,828 \\
36,157 \\
3,676 \\
1,336 \\
12,652 \\
13,706 \\
2,998 \\
\end{array}$ & $\begin{array}{l}-- \\
-- \\
-- \\
475 \\
-- \\
-- \\
-- \\
-- \\
-- \\
--\end{array}$ & $\begin{array}{r}1,449 \\
3,939 \\
-- \\
1,438 \\
6,318 \\
1,313 \\
-- \\
2,801 \\
2,924 \\
3,247 \\
\end{array}$ \\
\hline All types & 161,391 & 549,924 & 91,543 & 475 & 23,429 \\
\hline
\end{tabular}

Table 64.--Net volume of black walnut, by land class and tree class, Kansas, 1981

\begin{tabular}{|c|c|c|c|c|c|c|}
\hline \multirow{3}{*}{ Tree class } & & & \multicolumn{4}{|c|}{ Nonforest with trees } \\
\hline & \multicolumn{2}{|c|}{ Commercial forest } & \multicolumn{2}{|c|}{ Wooded strips } & \multicolumn{2}{|c|}{ Other nonforest with trees } \\
\hline & 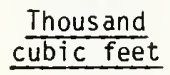 & Dhous and 1 board feet- & Thousand & Thous and 1 bord feet & Thousand & Dhous and 1 bard feet \\
\hline Growing stock & 57,868 & -- & 3,368 & - & 2,133 & -- \\
\hline Sawtimber & -- & 169,979 & -- & 8,669 & -- & 6,486 \\
\hline Short-log cull & 5,495 & 13,121 & 685 & 991 & 573 & 909 \\
\hline All classes & 68,747 & 183,100 & 4,540 & 9,660 & 3,461 & 7,395 \\
\hline
\end{tabular}

1/International $1 / 4$-inch rule. 
Table 65.--Net volume of growing-stock and short-log trees on commercial forest land and wooded strips, by species group and Forest Survey Unit, Kansas, 1981

(In thousand cubic feet)

ALL UNITS

\begin{tabular}{|c|c|c|c|c|c|}
\hline \multirow[b]{2}{*}{ Species group } & \multirow[b]{2}{*}{ Total } & \multicolumn{2}{|c|}{ Commercial forest land } & \multicolumn{2}{|c|}{ Wooded strips } \\
\hline & & $\begin{array}{c}\text { Growing-stock } \\
\text { trees }\end{array}$ & $\begin{array}{c}\text { Short-log } \\
\text { trees }\end{array}$ & $\begin{array}{c}\text { Growing-stock } \\
\text { trees }\end{array}$ & $\begin{array}{c}\text { Short-log } \\
\text { trees }\end{array}$ \\
\hline \multicolumn{6}{|l|}{ SOFTWOODS } \\
\hline Eastern redcedar & 6,077 & 4,591 & 410 & 1,076 & -- \\
\hline Total & 6,077 & 4,591 & 410 & 1,076 & -- \\
\hline \multicolumn{6}{|l|}{ HARDWOODS } \\
\hline Bur oak & 78,929 & 60,920 & 6,634 & 11,301 & 74 \\
\hline Select white oak & 39,284 & 34,121 & 4,875 & 258 & 30 \\
\hline Other white oak & 21,641 & 19,854 & 1,787 & -- & -- \\
\hline Select red oak & 49,432 & 45,828 & 1,755 & 1,658 & 191 \\
\hline Other red oak & 30,416 & 27,445 & 2,097 & 874 & -- \\
\hline Select hickory & 18,493 & 17,388 & 928 & 177 & -- \\
\hline Other hickory & 13,399 & 11,693 & 934 & 733 & 39 \\
\hline Pecan & 10,665 & 8,986 & 757 & 798 & 124 \\
\hline Hard maple & 3,245 & 3,120 & 125 & -- & -- \\
\hline Soft maple & 25,042 & 21,011 & 1,078 & 2,953 & -- \\
\hline Ash & 80,493 & 61,700 & 5,446 & 11,082 & 2,265 \\
\hline Cottonwood & 162,335 & 134,292 & 4,011 & 24,032 & - \\
\hline Basswood & 7,109 & 6,031 & 734 & 344 & -- \\
\hline Elm & 44,980 & 30,599 & 8,010 & 5,154 & 1,217 \\
\hline Black walnut & 67,416 & 57,868 & 5,495 & 3,368 & 685 \\
\hline Willow & 14,014 & 11,629 & 821 & 1,475 & 89 \\
\hline Boxelder & 17,609 & 10,376 & 3,487 & 2,174 & 1,572 \\
\hline Hackberry & 109,599 & 86,674 & 9,118 & 12,710 & 1,097 \\
\hline Sycamore & 26,445 & 21,538 & 250 & 4,657 & - \\
\hline Other hardwoods & 52,671 & 35,651 & 8,677 & 6,719 & 1,624 \\
\hline Total & 873,217 & 706,724 & 67,019 & 90,467 & 9,007 \\
\hline All species & 879,294 & 711,315 & 67,429 & 91,543 & 9,007 \\
\hline \multicolumn{6}{|c|}{ NORTHEASTERN UNIT } \\
\hline SOFTWOODS & & & & & \\
\hline Eastern redcedar & 2,851 & 2,446 & 225 & 180 & -- \\
\hline Total & 2,851 & 2,446 & 225 & 180 & $=-$ \\
\hline \multicolumn{6}{|l|}{ HARDWOODS } \\
\hline Bur oak & 34,479 & 29,902 & 3,708 & 869 & -- \\
\hline Select white oak & 25,682 & 22,050 & 3,602 & -- & 30 \\
\hline Other white oak & 2,315 & 2,107 & 208 & -- & - \\
\hline Select red oak & 26,738 & 25,577 & 911 & 250 & -- \\
\hline Other red oak & 16,583 & 15,385 & 788 & 410 & -- \\
\hline Select hickory & 12,395 & 11,801 & 430 & 164 & -- \\
\hline Other hickory & 7,690 & 6,665 & 719 & 267 & 39 \\
\hline Pecan & 265 & 265 & -- & -- & -- \\
\hline Hard maple & 1,938 & 1,938 & -- & -- & -- \\
\hline Soft maple & 13,003 & 10,459 & 633 & 1,911 & -- \\
\hline Ash & 18,511 & 13,845 & 1,283 & 3,159 & 224 \\
\hline Cottonwood & 48,389 & 43,561 & 1,017 & 3,811 & -- \\
\hline Basswood & 6,696 & 5,618 & 734 & 344 & -- \\
\hline E lm & 19,950 & 13,932 & 3,066 & 2,571 & 381 \\
\hline Black walnut & 37,917 & 32,366 & 2,945 & 1,959 & 647 \\
\hline Willow & 6,204 & 5,021 & 235 & 948 & -- \\
\hline Boxelder & 6,169 & 3,563 & 865 & 1,191 & 550 \\
\hline Hackberry & 45,013 & 37,640 & 2,871 & 3,883 & 619 \\
\hline Sycamore & 14,808 & 11,447 & 26 & 3,335 & - \\
\hline other hardwoods & 30,233 & 19,505 & 4,520 & 5,347 & 861 \\
\hline Total & 374,978 & 312,647 & 28,561 & 30,419 & 3,351 \\
\hline All species & 377,829 & 315,093 & 28,786 & 30,599 & 3,351 \\
\hline
\end{tabular}


SOUTHEASTERN UNIT

\begin{tabular}{|c|c|c|c|c|c|}
\hline \multirow[b]{2}{*}{ Species group } & \multirow[b]{2}{*}{ Total } & \multicolumn{2}{|c|}{ Commercial forest land } & \multicolumn{2}{|c|}{ Wooded strips } \\
\hline & & $\begin{array}{c}\text { Growing-stock } \\
\text { trees } \\
\end{array}$ & $\begin{array}{c}\text { Short }-109 \\
\text { trees }\end{array}$ & $\begin{array}{c}\text { Growing-stock } \\
\text { trees }\end{array}$ & $\begin{array}{c}\text { Short-log } \\
\text { trees }\end{array}$ \\
\hline \multirow{3}{*}{$\begin{array}{l}\text { SOFTWOODS } \\
\text { Eastern redcedar } \\
\text { Total }\end{array}$} & & & & & \\
\hline & 2,297 & 2,112 & 185 & -- & -- \\
\hline & 2,297 & 2,112 & 185 & -- & -- \\
\hline \multicolumn{6}{|l|}{ HARDWOODS } \\
\hline Bur oak & 19,183 & 15,644 & 1,613 & 1,852 & 74 \\
\hline Select white oak & 13,602 & 12,071 & 1,273 & 258 & -- \\
\hline Other white oak & 19,326 & 17,747 & 1,579 & -- & -- \\
\hline Select red oak & 22,694 & 20,251 & 844 & 1,408 & 191 \\
\hline Other red oak & 13,833 & 12,060 & 1,309 & 464 & -- \\
\hline Select hickory & 6,098 & 5,587 & 498 & 13 & -- \\
\hline Other hickory & 5,709 & 5,028 & 215 & 466 & -- \\
\hline Pecan & 10,257 & 8,578 & 757 & 798 & 124 \\
\hline Hard maple & 1,307 & 1,182 & 125 & -- & -- \\
\hline Soft maple & 11,912 & 10,552 & 318 & 1,042 & -- \\
\hline Ash & 30,634 & 26,734 & 1,759 & 1,232 & 909 \\
\hline Cottonwood & 11,272 & 9,786 & 438 & 1,048 & -- \\
\hline Basswood & 413 & 413 & -- & & -- \\
\hline Elm & 19,065 & 12,589 & 3,150 & 2,490 & 836 \\
\hline Black walnut & 26,920 & 23,004 & 2,469 & 1,409 & 38 \\
\hline Willow & 4,860 & 4,204 & 284 & 283 & 89 \\
\hline Boxelder & 4,114 & 1,831 & 708 & 983 & 592 \\
\hline Hackberry & 45,226 & 38,441 & 2,275 & 4,328 & 182 \\
\hline Sycamore & 11,333 & 9,787 & 224 & 1,322 & -- \\
\hline Other hardwoods & 15,694 & 11,527 & 2,032 & 1,372 & 763 \\
\hline Total & 293,452 & 247,016 & 21,870 & 20,768 & 3,798 \\
\hline All species & 295,749 & 249,128 & 22,055 & 20,768 & 3,798 \\
\hline \multicolumn{6}{|c|}{ WESTERN UNIT } \\
\hline \multirow{2}{*}{\multicolumn{6}{|c|}{$\begin{array}{l}\text { SOFTWOODS } \\
\text { Eastern redcedar }\end{array}$}} \\
\hline & 929 & 33 & -- & 896 & -- \\
\hline Total & 929 & 33 & -- & 896 & $=-$ \\
\hline \multicolumn{6}{|l|}{ HARDWOODS } \\
\hline Bur oak & 25,267 & 15,374 & 1,313 & 8,580 & -- \\
\hline Select white oak & -- & -- & -- & -- & -- \\
\hline Other white oak & -- & -- & -- & -- & -- \\
\hline Select red oak & -- & -- & -- & -- & -- \\
\hline Other red oak & -- & -- & -- & $-\rightarrow$ & -- \\
\hline Select hickory & -- & -- & -- & - & -- \\
\hline Other hickory & -- & -- & -- & -- & -- \\
\hline Pecan & 143 & 143 & -- & -- & -- \\
\hline Hard maple & -- & -- & 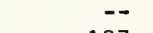 & -- & -- \\
\hline Soft maple & 127 & -- & 127 & -- & -- \\
\hline Ash & 31,348 & 21,121 & 2,404 & 6,691 & 1,132 \\
\hline Cottonwood & 102,674 & 80,945 & 2,556 & 19,173 & -- \\
\hline Basswood & -- & -- & -- & -- & -- \\
\hline Elm & 5,965 & 4,078 & 1,794 & 93 & -- \\
\hline Black walnut & 2,579 & 2,498 & 81 & - & -- \\
\hline Willow & 2,950 & 2,404 & 302 & 244 & -- \\
\hline Boxelder & 7,326 & 4,982 & 1,914 & -- & 430 \\
\hline Hackberry & 19,360 & 10,593 & 3,972 & 4,499 & 296 \\
\hline Sycamore & 304 & 304 & -- & -- & -- \\
\hline Other hardwoods & 6,744 & 4,619 & 2,125 & -- & -- \\
\hline Total & 204,787 & 147,061 & 16,588 & 39,280 & 1,858 \\
\hline All species & 205,716 & 147,094 & 16,588 & 40,176 & 1,858 \\
\hline
\end{tabular}


Table 66.--Net volume of sawtimber and short-log trees on commercial forest land and wooded strips, by species group and Forest Survey Unit, Kansas, 1981

(In thousand board feet) $\underline{\text { I' }}$

ALL UNITS

\begin{tabular}{|c|c|c|c|c|c|}
\hline \multirow[b]{2}{*}{ Species group } & \multirow[b]{2}{*}{ Total } & \multicolumn{2}{|c|}{ Commercial forest land } & \multicolumn{2}{|c|}{ Wooded strips } \\
\hline & & $\begin{array}{c}\text { Sawtimber } \\
\text { trees }\end{array}$ & $\begin{array}{c}\text { Short-log } \\
\text { trees }\end{array}$ & $\begin{array}{c}\text { Sawt imber } \\
\text { trees }\end{array}$ & $\begin{array}{c}\text { Short-log } \\
\text { trees }\end{array}$ \\
\hline \multicolumn{6}{|l|}{ SOFTWOODS } \\
\hline Eastern redcedar & 12,870 & 10,871 & 779 & 1,220 & -- \\
\hline Total & 12,870 & 10,871 & 779 & 1,220 & -- \\
\hline \multicolumn{6}{|l|}{ HARDWOODS } \\
\hline Bur oak & 350,299 & 286,120 & 16,080 & 48,099 & -- \\
\hline Select white oak & 119,652 & 107,383 & 12,269 & -- & -- \\
\hline Other white oak & 38,525 & 36,531 & 1,994 & -- & -- \\
\hline Select red oak & 192,823 & 183,457 & 4,733 & 4,633 & -- \\
\hline 0ther red oak & 128,529 & 118,665 & 6,328 & 3,536 & -- \\
\hline Select hickory & 44,878 & 43,047 & 1,831 & -- & -- \\
\hline Other hickory & 27,293 & 24,649 & 1,685 & 959 & -- \\
\hline Pecan & 33,204 & 28,043 & 1,903 & 2,860 & 398 \\
\hline Hard maple & 6,613 & 6,280 & 333 & -- & -- \\
\hline Soft maple & 101,089 & 87,834 & 2,571 & 10,684 & -- \\
\hline Ash & 236,913 & 185,760 & 11,798 & 34,894 & 4,461 \\
\hline Cottonwood & 707,410 & 610,060 & 13,704 & 83,646 & -- \\
\hline Basswood & 28,141 & 25,763 & 1,571 & 807 & -- \\
\hline Elm & 92,790 & 69,531 & 12,387 & 9,199 & 1,673 \\
\hline Black walnut & 192,760 & 169,979 & 13,121 & 8,669 & 991 \\
\hline Willow & 57,075 & 47,901 & 2,355 & 6,433 & 386 \\
\hline Boxelder & 39,152 & 22,839 & 7,992 & 5,125 & 3,196 \\
\hline Hackberry & 363,523 & 299,581 & 21,596 & 41,472 & 874 \\
\hline Sycamore & 120,423 & 105,631 & 370 & 14,422 & -- \\
\hline Other hardwoods & 135,631 & 96,304 & 12,504 & 23,399 & 3,424 \\
\hline Total & $3,016,723$ & $2,555,358$ & 147,125 & 298,837 & 15,403 \\
\hline \multirow[t]{2}{*}{ All species } & $3,029,593$ & $2,566,229$ & 147,904 & 300,057 & 15,403 \\
\hline & \multicolumn{5}{|c|}{ NORTHEASTERN UNIT } \\
\hline SOFTWOODS & & & & & \\
\hline Eastern redcedar & 5,209 & 5,106 & 103 & $=-$ & -- \\
\hline Total & 5,209 & 5,106 & 103 & -- & - \\
\hline \multicolumn{6}{|l|}{ HARDWOODS } \\
\hline Bur oak & 136,514 & 124,290 & 8,605 & 3,619 & -- \\
\hline Select white oak & 87,258 & 77,476 & 9,782 & -- & -- \\
\hline 0ther white oak & 6,476 & 6,145 & 331 & -- & -- \\
\hline Select red oak & 106,363 & 104,284 & 2,079 & -- & -- \\
\hline 0ther red oak & 76,262 & 70,133 & 3,922 & 2,207 & -- \\
\hline Select hickory & 24,651 & 24,060 & 591 & - & -- \\
\hline 0ther hickory & 15,851 & 14,453 & 1,398 & -- & -- \\
\hline Pecan & 575 & 575 & -- & -- & -- \\
\hline Hard maple & 3,635 & 3,635 & & -- & -- \\
\hline Soft maple & 53,320 & 44,464 & 1,384 & 7,472 & -- \\
\hline Ash & 57,355 & 42,154 & 2,698 & 12,186 & 317 \\
\hline Cottonwood & 212,554 & 196,103 & 2,572 & 13,879 & -- \\
\hline Basswood & 27,185 & 24,807 & 1,571 & 807 & -- \\
\hline Elm & 33,538 & 25,507 & 3,148 & 4,536 & 347 \\
\hline Black walnut & 111,345 & 96,526 & 8,285 & 5,543 & 991 \\
\hline Willow & 23,260 & 19,065 & 257 & 3,938 & -- \\
\hline Boxelder & 9,787 & 5,924 & 1,818 & 1,129 & 916 \\
\hline Hackberry & 133,687 & 112,814 & 8,586 & 11,413 & 874 \\
\hline Sycamore & 64,790 & 56,268 & -- & 8,522 & -- \\
\hline Other hardwoods & 81,192 & 53,824 & 6,979 & 18,801 & 1,588 \\
\hline Total & $1,265,598$ & $1,102,507$ & 64,006 & 94,052 & 5,033 \\
\hline All species & $1,270,807$ & $1,107,613$ & 64,109 & 94,052 & 5,033 \\
\hline
\end{tabular}

1/International $1 / 4$-inch rule.

(Table 66 continued on next page) 
SOUTHEASTERN UNIT

\begin{tabular}{|c|c|c|c|c|c|}
\hline \multirow[b]{2}{*}{ Species group } & \multirow[b]{2}{*}{ Total } & \multicolumn{2}{|c|}{ Commercial forest land } & \multicolumn{2}{|c|}{ Wooded strips } \\
\hline & & $\begin{array}{c}\text { Growing-stock } \\
\text { trees }\end{array}$ & $\begin{array}{c}\text { Short }-10 g \\
\text { trees }\end{array}$ & $\begin{array}{c}\text { Growing-stock } \\
\text { trees }\end{array}$ & $\begin{array}{c}\text { Short-log } \\
\text { trees }\end{array}$ \\
\hline \multicolumn{6}{|l|}{ SOFTWOODS } \\
\hline Eastern redcedar & 6,441 & 5,765 & 676 & -- & -- \\
\hline Total & 6,441 & 5,765 & 676 & -- & -- \\
\hline \multicolumn{6}{|l|}{ HARDWOODS } \\
\hline Bur oak & 83,901 & 72,739 & 3,331 & 7,831 & -- \\
\hline Select white oak & 32,394 & 29,907 & 2,487 & - & -- \\
\hline Other white oak & 32,049 & 30,386 & 1,663 & -- & -- \\
\hline Select red oak & 86,460 & 79,173 & 2,654 & 4,633 & -- \\
\hline Other red oak & 52,267 & 48,532 & 2,406 & 1,329 & -- \\
\hline Select hickory & 20,227 & 18,987 & 1,240 & - & -- \\
\hline Other hickory & 11,442 & 10,196 & 287 & 959 & -- \\
\hline Pecan & 31,869 & 26,708 & 1,903 & 2,860 & 398 \\
\hline Hard maple & 2,978 & 2,645 & 333 & -- & -- \\
\hline Soft maple & 47,363 & 43,370 & 781 & 3,212 & -- \\
\hline Ash & 96,218 & 87,049 & 3,406 & 3,867 & 1,896 \\
\hline Cottonwood & 45,351 & 39,358 & 1,244 & 4,749 & -- \\
\hline Basswood & 956 & 956 & -- & -- & -- \\
\hline Elm & 40,542 & 29,537 & 5,016 & 4,663 & 1,326 \\
\hline Black walnut & 73,954 & 65,992 & 4,836 & 3,126 & -- \\
\hline Willow & 18,858 & 16,467 & 637 & 1,368 & 386 \\
\hline Boxelder & 13,231 & 6,077 & 1,488 & 3,996 & 1,670 \\
\hline Hackberry & 158,074 & 137,513 & 5,239 & 15,322 & -- \\
\hline Sycamore & 53,923 & 47,653 & 370 & 5,900 & -- \\
\hline Other hardwoods & 38,647 & 29,536 & 2,677 & 4,598 & 1,836 \\
\hline Total & 940,704 & 822,781 & 41,998 & 68,413 & 7,512 \\
\hline All species & 947,145 & 828,546 & 42,674 & 68,413 & 7,512 \\
\hline \multicolumn{6}{|c|}{ WESTERN UNIT } \\
\hline SOFTWOODS & & & & & \\
\hline Eastern redcedar & 1,220 & - & -- & 1,220 & -- \\
\hline Total & 1,220 & -- & $=$ & 1,220 & -- \\
\hline \multicolumn{6}{|l|}{ HARDWOODS } \\
\hline Bur oak & 129,884 & 89,091 & 4,144 & 36,649 & -- \\
\hline Select white oak & -- & -- & -- & -- & -- \\
\hline Other white oak & -- & -- & -- & -- & $\rightarrow$ \\
\hline Select red oak & -- & -- & -- & -- & -- \\
\hline Other red oak & -- & -- & -- & -- & -- \\
\hline Select hickory & -- & -- & -- & -- & -- \\
\hline other hickory & -- & -- & -- & -- & -- \\
\hline Pecan & 760 & 760 & -- & -- & -- \\
\hline Hard maple & -- & -- & -- & -- & -- \\
\hline Soft maple & 406 & -- & 406 & -- & -- \\
\hline Ash & 83,340 & 56,557 & 5,694 & 18,841 & 2,248 \\
\hline Cottonwood & 449,505 & 374,599 & 9,888 & 65,018 & -- \\
\hline Basswood & -- & -- & - & -- & -- \\
\hline Elm & 18,710 & 14,487 & 4,223 & -- & -- \\
\hline Black walnut & 7,461 & 7,461 & -- & -- & -- \\
\hline Willow & 14,957 & 12,369 & 1,461 & 1,127 & -- \\
\hline Boxelder & 16,134 & 10,838 & 4,686 & -- & 610 \\
\hline Hackberry & 71,762 & 49,254 & 7,771 & 14,737 & -- \\
\hline Sycamore & 1,710 & 1,710 & -- & -- & -- \\
\hline Other hardwoods & 15,792 & 12,944 & 2,848 & -- & -- \\
\hline Total & 810,421 & 630,070 & 41,121 & 136,372 & 2,858 \\
\hline All species & 811,641 & 630,070 & 41,121 & 137,592 & 2,858 \\
\hline
\end{tabular}




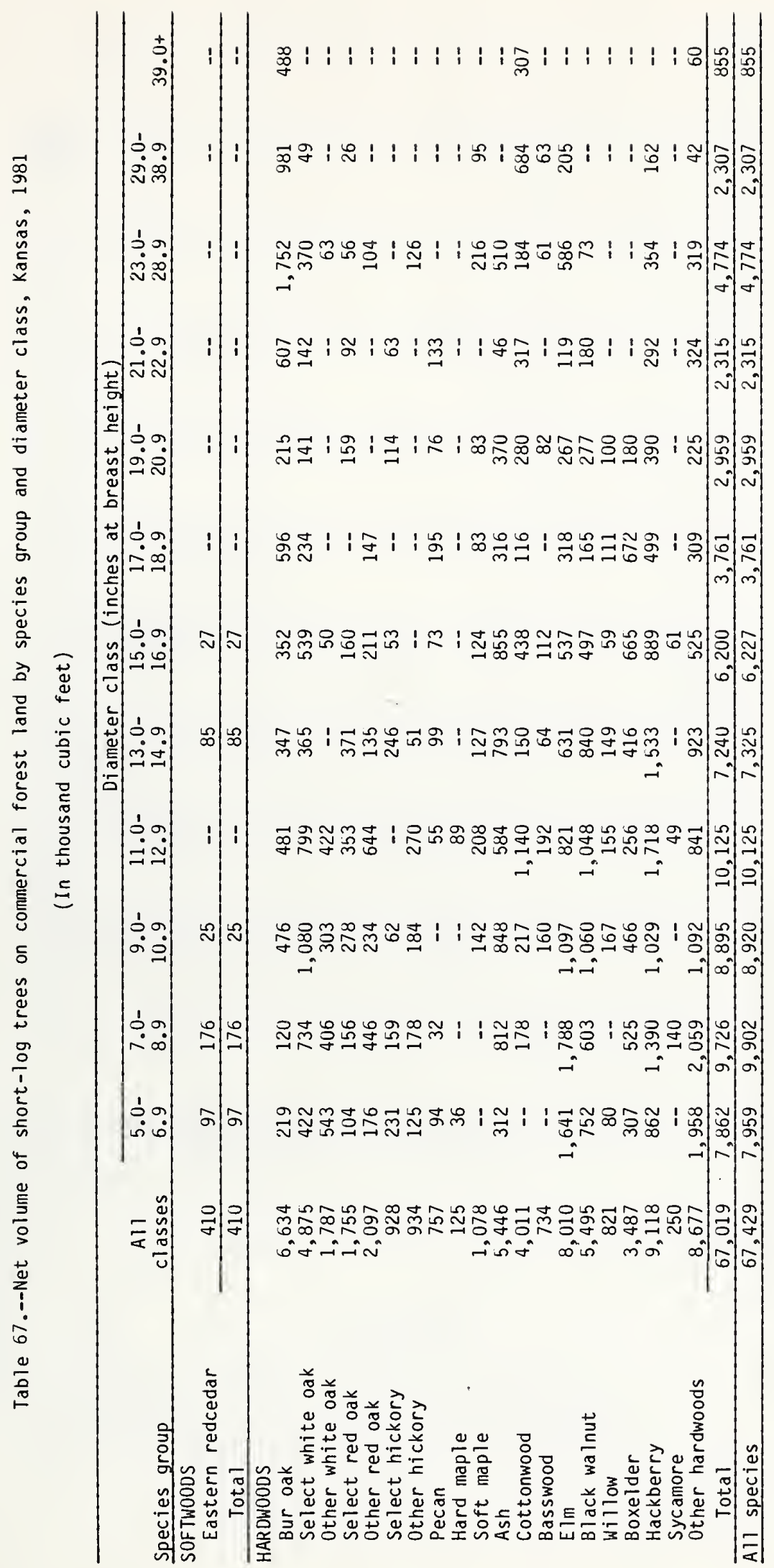




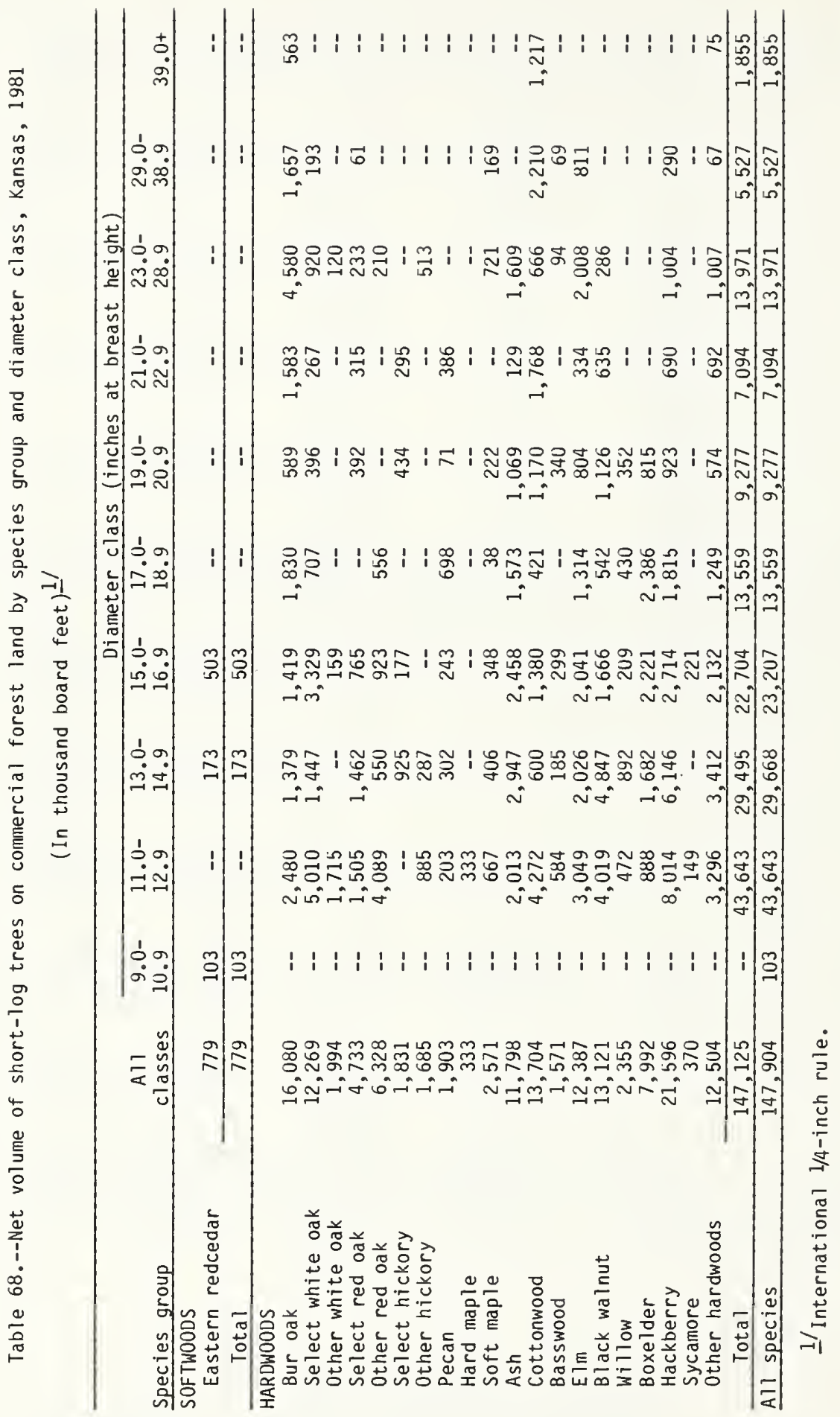




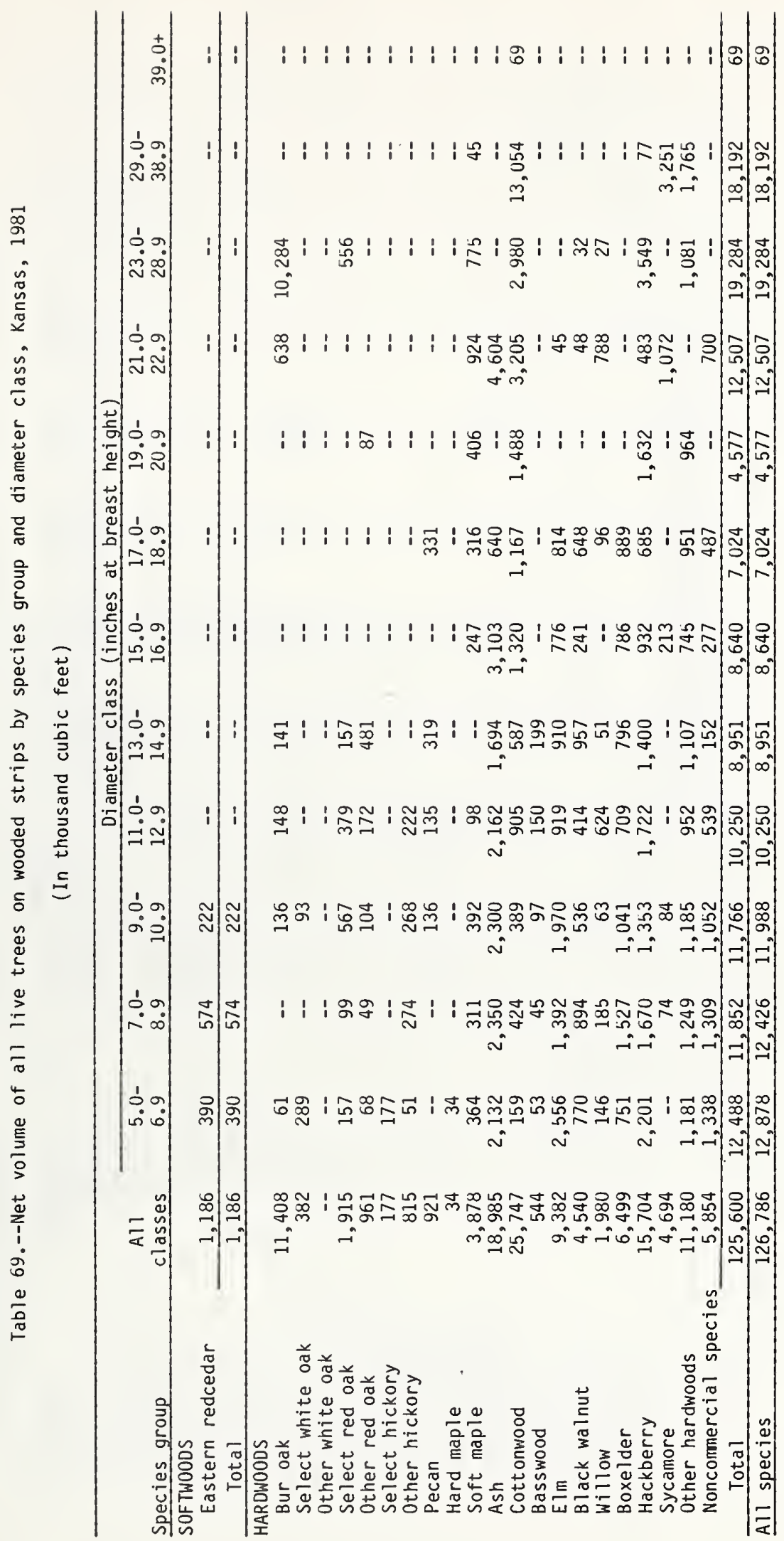




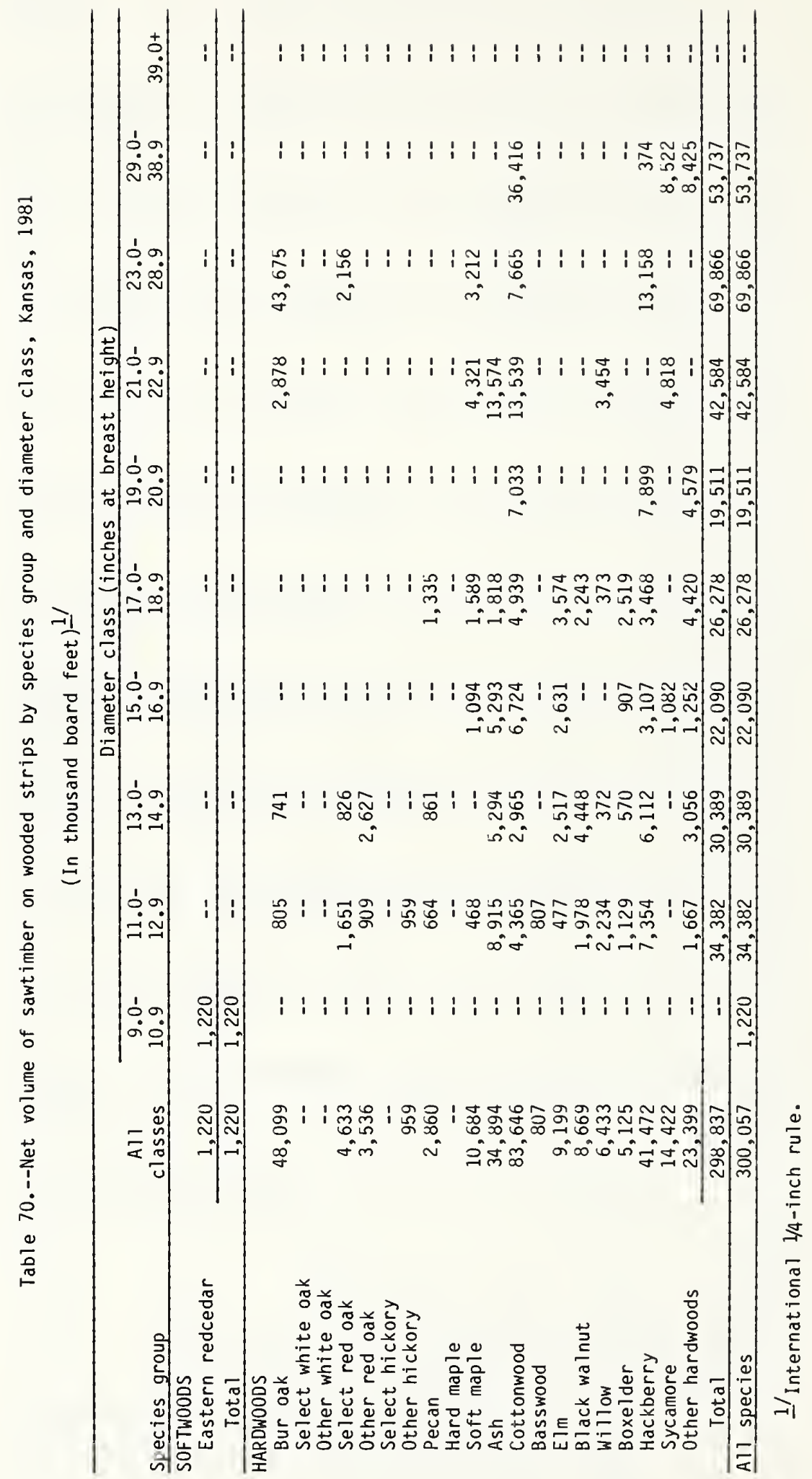




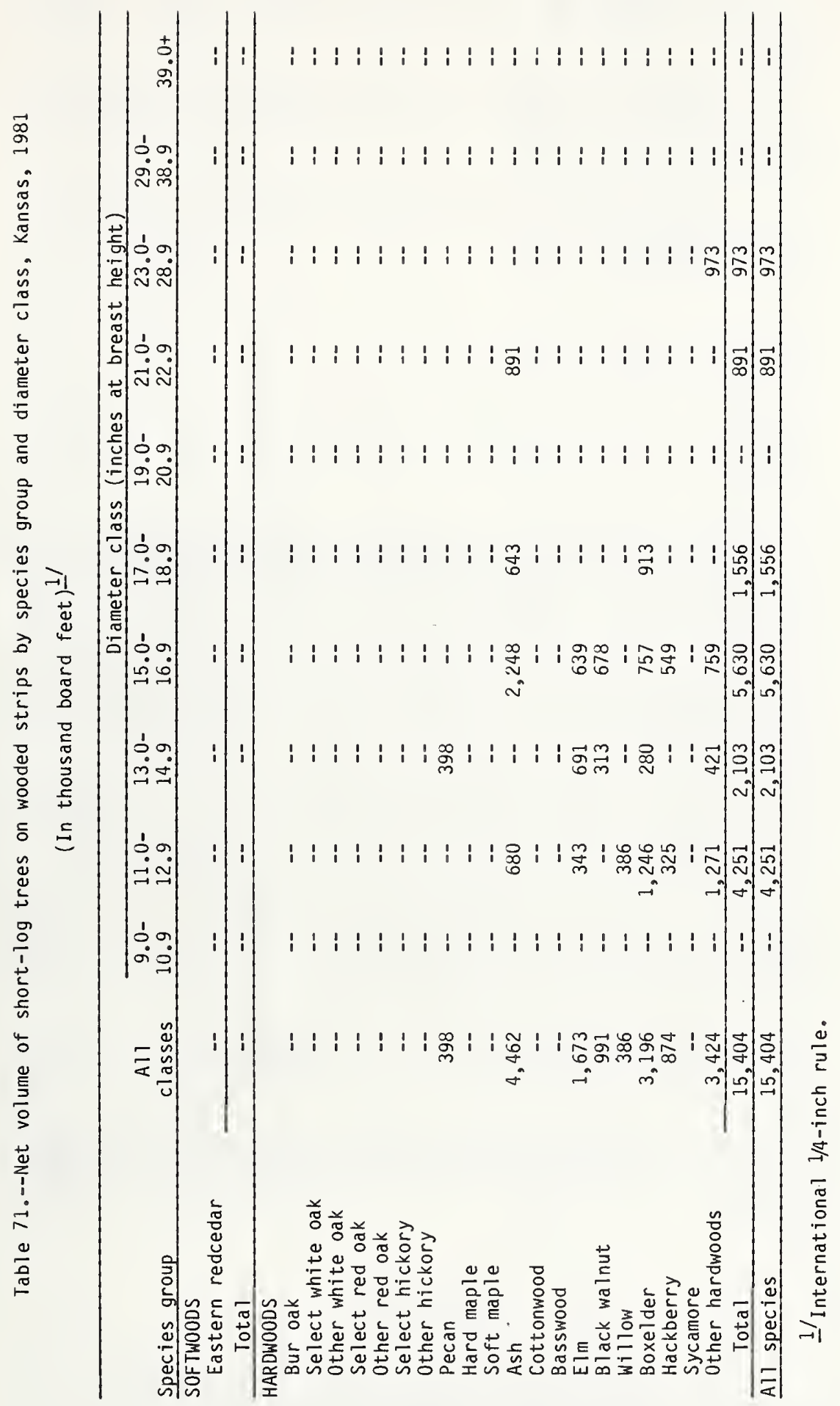




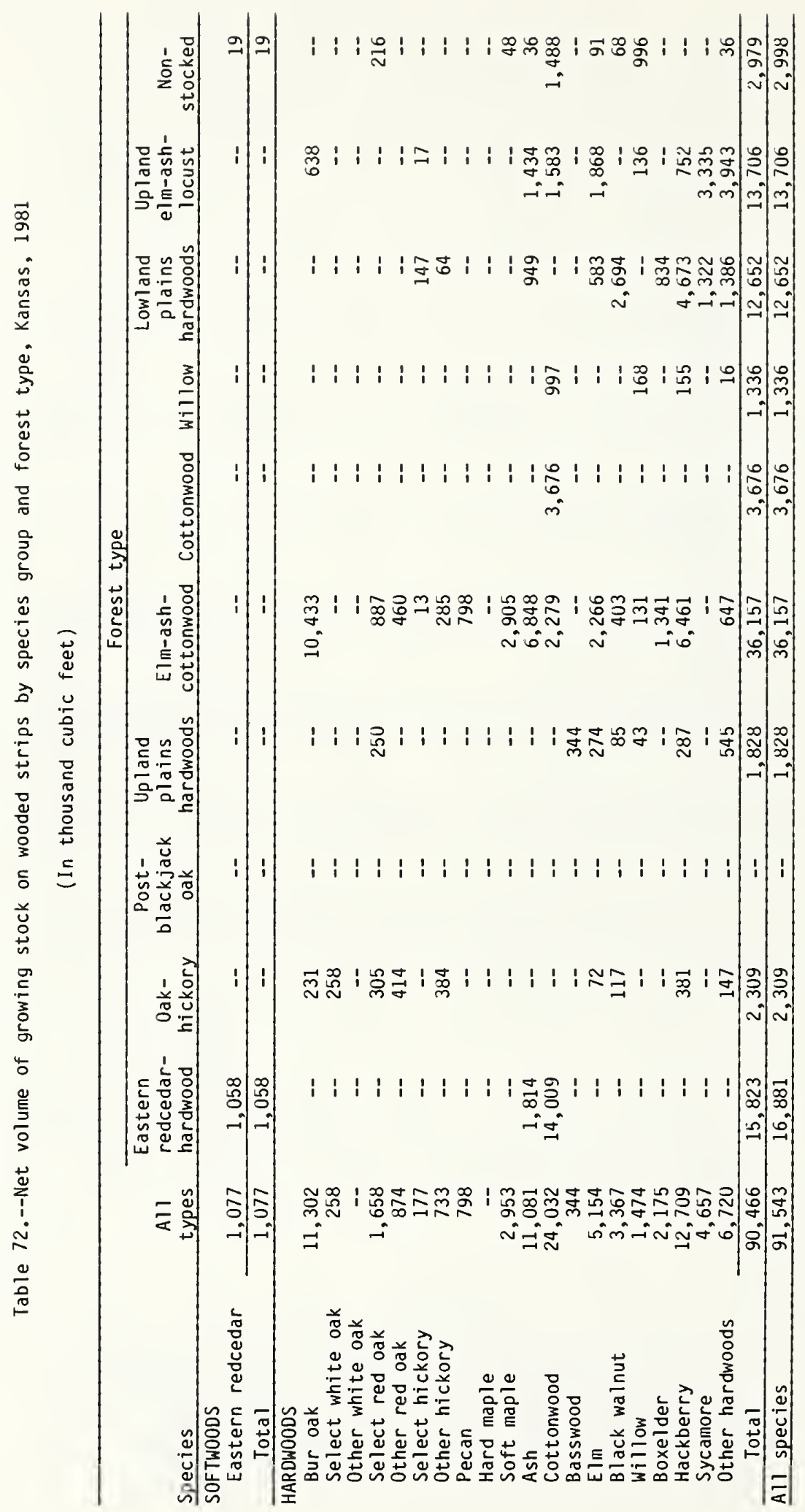




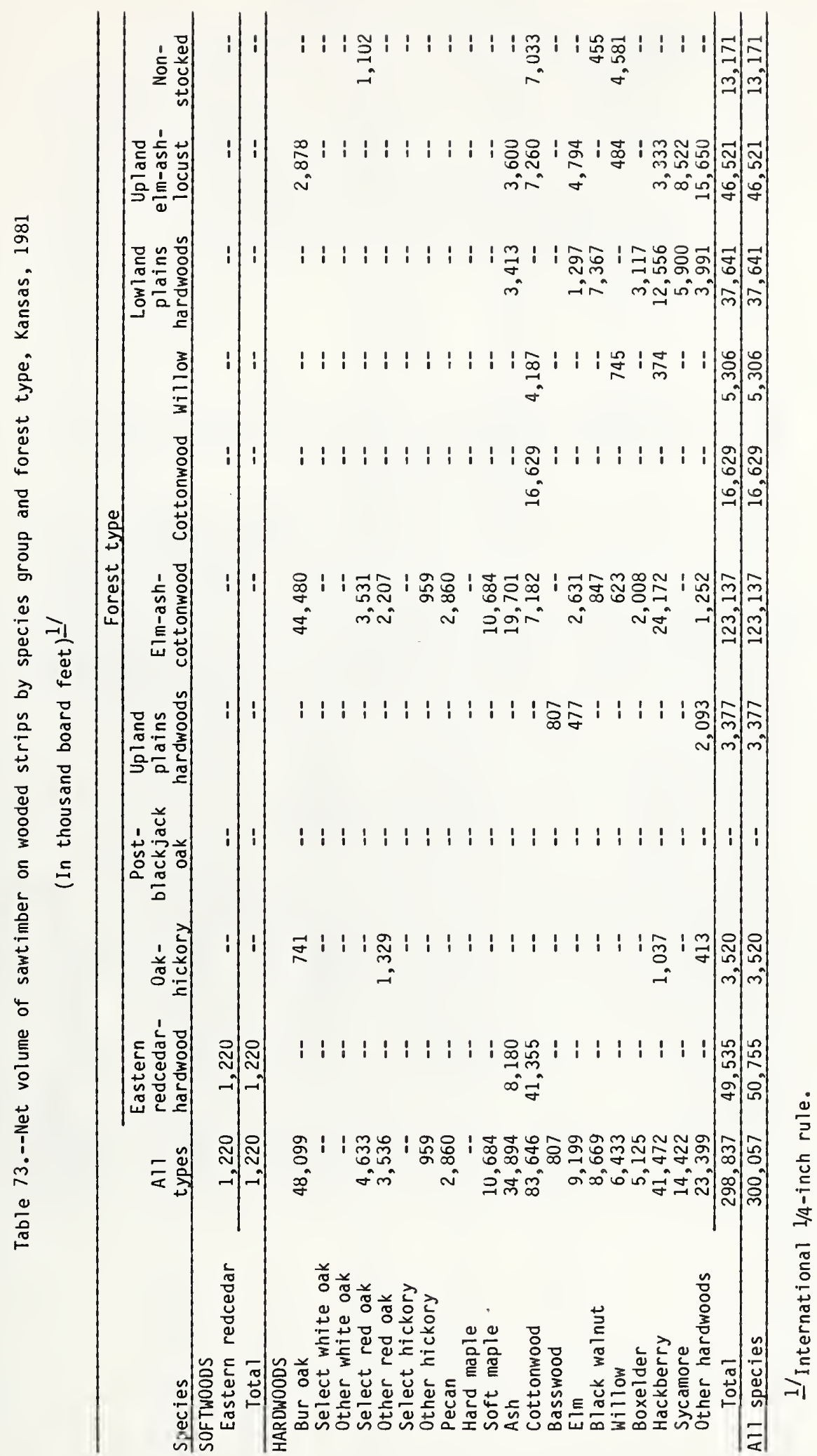


Table 74.--Net annual growth of growing stock on commercial forest land by softwoods and hardwoods, Kansas, 1964 and 1980

(In thousand cubic feet)

\begin{tabular}{lrr}
\hline Species & $1964-1 /$ & 1980 \\
\hline Softwoods & -- & 471 \\
Hardwoods & 22,100 & 22,759 \\
\cline { 2 - 3 } All species & 22,100 & 23,230 \\
\hline
\end{tabular}

$1 /$ Figures have been adjusted from those pub1 ished after the 1965 survey to conform to 1980 volumes because of changes in survey definitions and procedures.

Table 75.--Net annual growth of growing stock on commercial forest land by species group and Forest Survey Unit, Kansas, 1980

(In thousand cubic feet)

\begin{tabular}{|c|c|c|c|c|}
\hline \multirow[b]{2}{*}{ Species group } & \multirow[b]{2}{*}{$\begin{array}{l}\text { All } \\
\text { Units }\end{array}$} & \multicolumn{3}{|c|}{ Forest Survey Unit } \\
\hline & & $\begin{array}{c}\text { North- } \\
\text { eastern } \\
\text { Unit }\end{array}$ & $\begin{array}{c}\text { South- } \\
\text { eastern } \\
\text { Unit }\end{array}$ & $\begin{array}{c}\text { Western } \\
\text { Unit }\end{array}$ \\
\hline \multicolumn{5}{|l|}{ SOFTWOODS } \\
\hline Eastern redcedar & 471 & 271 & 197 & 3 \\
\hline Total & 471 & 271 & 197 & 3 \\
\hline \multicolumn{5}{|l|}{ HARDWOODS } \\
\hline Bur oak & 1,251 & 576 & 433 & 242 \\
\hline Select white oak & 779 & 485 & 294 & -- \\
\hline 0ther white oak & 594 & 43 & 551 & -- \\
\hline Select red oak & 1,467 & 674 & 793 & -- \\
\hline Other red oak & 611 & 282 & 329 & -- \\
\hline Select hickory & 467 & 341 & 126 & -- \\
\hline Other hickory & 470 & 341 & 129 & -- \\
\hline Pecan & 254 & 4 & 247 & 3 \\
\hline Hard maple & 94 & 58 & 36 & -- \\
\hline Soft maple & 941 & 423 & 518 & -- \\
\hline Ash & 1,958 & 403 & 892 & 663 \\
\hline Cottonwood & 2,525 & 1,023 & 179 & 1,323 \\
\hline Basswood & 199 & 166 & 33 & -- \\
\hline Elm & 678 & 224 & 538 & -84 \\
\hline Black walnut & 2,167 & 926 & 1,010 & 231 \\
\hline Willow & 382 & 138 & 131 & 113 \\
\hline Boxelder & 762 & 226 & 68 & 468 \\
\hline Hackberry & 4,454 & 1,755 & 2,184 & 515 \\
\hline Sycamore & 590 & 268 & 314 & 8 \\
\hline Other hardwoods & 2,116 & 1,032 & 708 & 376 \\
\hline Total & 22,759 & 9,388 & 9,513 & 3,858 \\
\hline All species & 23,230 & 9,659 & 9,710 & 3,861 \\
\hline
\end{tabular}


Table 76. - Net annual growth of sawtimber on commercial forest land by species group and Forest Survey Unit, Kansas, 1980

(In thousand board feet) $\underline{1 /}$

\begin{tabular}{|c|c|c|c|c|}
\hline \multirow[b]{2}{*}{ Species group } & \multirow[b]{2}{*}{$\begin{array}{c}\text { Al1 } \\
\text { Units }\end{array}$} & \multicolumn{3}{|c|}{ Forest Survey Unit } \\
\hline & & $\begin{array}{l}\text { North- } \\
\text { eastern } \\
\text { Unit }\end{array}$ & $\begin{array}{l}\text { South- } \\
\text { eastern } \\
\text { Unit }\end{array}$ & $\begin{array}{c}\text { Western } \\
\text { Unit }\end{array}$ \\
\hline \multicolumn{5}{|l|}{ SOFTWOODS } \\
\hline Eastern redcedar & 90 & 95 & -5 & -- \\
\hline Tota 1 & 90 & 95 & -5 & -- \\
\hline \multicolumn{5}{|l|}{ HARDWOODS } \\
\hline Bur oak & 4,255 & 1,738 & 1,408 & 1,109 \\
\hline Select white oak & 2,041 & 1,772 & 269 & - \\
\hline Other white oak & 460 & 102 & 358 & -- \\
\hline Select red oak & 7,275 & 3,977 & 3,298 & -- \\
\hline Other red oak & 1,179 & 902 & 277 & -- \\
\hline Select hickory & 953 & 796 & 157 & -- \\
\hline Other hickory & 1,060 & 479 & 581 & -- \\
\hline Pecan & 1,113 & 1 & 1,103 & 9 \\
\hline Hard maple & 607 & 66 & 541 & -- \\
\hline Soft maple & 3,170 & 1,462 & 1,708 & -- \\
\hline Ash & 4,768 & 870 & 3,299 & 599 \\
\hline Cottonwood & 8,773 & 2,432 & 1,003 & 5,338 \\
\hline Basswood & 360 & 354 & 6 & - \\
\hline E $1 \mathrm{~m}$ & $-2,234$ & $-2,142$ & 763 & -855 \\
\hline Black walnut & 5,911 & 2,892 & 2,994 & 25 \\
\hline Willow & 2,742 & 1,860 & 444 & 438 \\
\hline Boxelder & 1,642 & 728 & 476 & 438 \\
\hline Hackberry & 13,246 & 5,463 & 6,444 & 1,339 \\
\hline Sycamore & 2,403 & 892 & 1,482 & 29 \\
\hline Other hardwoods & 4,223 & 2,782 & 984 & 457 \\
\hline Total & 63,947 & 27,426 & 27,595 & 8,926 \\
\hline All species & 64,037 & 27,521 & 27,590 & 8,926 \\
\hline
\end{tabular}

1/International $1 / 4$-inch rule.

Table 77.--Net annual growth of growing stock on commercial forest land by species group and ownership class, Kansas, 1980

(In thousand cubic feet)

\begin{tabular}{|c|c|c|c|c|c|c|c|c|}
\hline \multirow[b]{2}{*}{ Species group } & \multirow[b]{2}{*}{$\begin{array}{c}\text { A11 } \\
\text { classes }\end{array}$} & \multicolumn{7}{|c|}{ Ownership class } \\
\hline & & $\begin{array}{c}\text { Nationa } 1 \\
\text { forest }\end{array}$ & $\begin{array}{c}\text { Misc. } \\
\text { federal }\end{array}$ & Indian & State & $\begin{array}{c}\text { County and } \\
\text { municipal }\end{array}$ & Farmer & $\begin{array}{l}\text { Misc. } \\
\text { private }\end{array}$ \\
\hline \multicolumn{9}{|l|}{ SOFTW0ODS } \\
\hline Eastern redcedar & 471 & -- & 2 & -- & -- & -- & 325 & 144 \\
\hline Total & 471 & -- & 2 & - & $=$ & -- & 325 & 144 \\
\hline \multicolumn{9}{|l|}{ HARDWOODS } \\
\hline Bur oak & 1,251 & -- & 164 & -- & 4 & -- & 715 & 368 \\
\hline Select white oak & 779 & -- & 15 & -- & -- & 7 & 314 & 443 \\
\hline 0ther white oak & 594 & -- & 18 & -- & -- & -- & 432 & 144 \\
\hline Select red oak & 1,467 & -- & 27 & -- & -- & -- & 891 & 549 \\
\hline other red oak & 611 & -- & 6 & -- & 22 & -- & 270 & 313 \\
\hline Select hickory & 467 & - & 13 & -- & 4 & -- & 252 & 198 \\
\hline Other hickory & 470 & -- & 8 & -- & -- & -- & 309 & 153 \\
\hline Pecan & 254 & -- & - & -- & 2 & -- & 113 & 139 \\
\hline Hard maple & 94 & -- & -- & -- & $=$ & -- & 29 & 65 \\
\hline Soft maple & 941 & -- & 22 & -- & 75 & 42 & 567 & 235 \\
\hline Ash & 1,958 & -- & 40 & - & 25 & -- & 1,347 & 546 \\
\hline Cottonwood & 2,525 & -- & 276 & 2. & 159 & -- & 1,656 & 432 \\
\hline Basswood & 199 & -- & 2 & -- & -- & -- & 125 & 72 \\
\hline Elm & 678 & -- & 52 & 3 & 5 & 2 & 519 & 97 \\
\hline Black walnut & 2,167 & -- & 50 & -- & 2 & -- & 1,162 & 953 \\
\hline Willow & 382 & -- & 2 & -- & 4 & 23 & 248 & 105 \\
\hline Boxelder & 762 & - & - & - & -- & 10 & 475 & 277 \\
\hline Hackberry & 4,454 & -- & 203 & 7 & 2 & 54 & 2,828 & 1,360 \\
\hline Sycamore & 590 & -- & 42 & -- & -- & - & 447 & 101 \\
\hline Other hardwoods & 2,116 & $=-$ & 78 & 13 & 12 & 14 & 1,336 & 663 \\
\hline Total & 22,759 & - & 1,018 & 25 & 316 & 152 & 14,035 & 7,213 \\
\hline All species & 23,230 & -- & 1,020 & 25 & 316 & 152 & 14,360 & 7,357 \\
\hline
\end{tabular}


Table 78.--Net annual growth of sawtimber on commercial forest land by species group and ownership class, Kansas, 1980

(In thousand board feet) $1 /$

\begin{tabular}{|c|c|c|c|c|c|c|c|c|}
\hline \multirow[b]{2}{*}{ Species group } & \multirow[b]{2}{*}{$\begin{array}{c}\text { All } \\
\text { classes } \\
\end{array}$} & \multicolumn{7}{|c|}{ Ownership class } \\
\hline & & $\begin{array}{c}\text { National } \\
\text { forest }\end{array}$ & $\begin{array}{c}\text { Misc. } \\
\text { federal }\end{array}$ & Indian & State & $\begin{array}{r}\text { County and } \\
\text { municipal }\end{array}$ & Farmer & $\begin{array}{l}\text { Misc. } \\
\text { private }\end{array}$ \\
\hline \multicolumn{9}{|l|}{ SOFTWOODS } \\
\hline Eastern redcedar & 90 & $=$ & $=$ & $=$ & $=$ & $=$ & 70 & 20 \\
\hline Total & 90 & $=-$ & - & - & $=$ & $=$ & 70 & 20 \\
\hline \multicolumn{9}{|l|}{ HARDWOODS } \\
\hline Bur oak & 4,255 & -- & 104 & -- & 11 & -- & 2,954 & 1,186 \\
\hline Select white oak & 2,041 & -- & 30 & -- & -- & -- & 1,395 & 616 \\
\hline Other white oak & 460 & -- & 39 & -- & -- & -- & 355 & 66 \\
\hline Select red oak & 7,275 & -- & 627 & -- & -- & -- & 2,689 & 3,959 \\
\hline Other red oak & 1,179 & -- & -- & -- & 116 & -- & 158 & 905 \\
\hline Select hickory & 953 & -- & 3 & -- & 8 & -- & 305 & 637 \\
\hline Other hickory & 1,060 & -- & -- & -- & -- & -- & 93 & 967 \\
\hline Pecan & 1,113 & -- & -- & -- & 6 & -- & 807 & 300 \\
\hline Hard maple & 607 & -- & -- & -- & -- & -- & 308 & 299 \\
\hline Soft maple & 3,170 & -- & 95 & -- & 250 & 237 & 1,177 & 1,411 \\
\hline Ash & 4,768 & -- & 112 & -- & 420 & - & 3,323 & 913 \\
\hline Cottonwood & 8,773 & -- & 843 & 2 & -- & -- & 6,435 & 1,493 \\
\hline Basswood & 360 & -- & 9 & -- & -- & -- & 240 & 111 \\
\hline Elm & $-2,234$ & -- & -14 & -- & -- & 7 & $-1,392$ & -835 \\
\hline Black walnut & 5,911 & -- & 211 & -- & 13 & -- & 3,560 & 2,127 \\
\hline Willow & 2,742 & -- & -- & -- & -- & 187 & 2,155 & 400 \\
\hline Boxelder & 1,642 & -- & -- & -- & - & 367 & 685 & 590 \\
\hline Hackberry & 13,246 & -- & 340 & 13 & 9 & 120 & 8,437 & 4,327 \\
\hline Sycamore & 2,403 & -- & 148 & -- & -- & -- & 1,938 & 317 \\
\hline Other hardwoods & 4,223 & $=$ & 111 & 44 & 33 & 70 & 2,131 & 1,834 \\
\hline Total & 63,947 & $=-$ & 2,658 & 59 & 866 & 988 & 37,753 & 21,623 \\
\hline All species & 64,037 & -- & 2,658 & 59 & 866 & 988 & 37,823 & 21,643 \\
\hline
\end{tabular}

1/International $1 / 4-$ inch rule. 


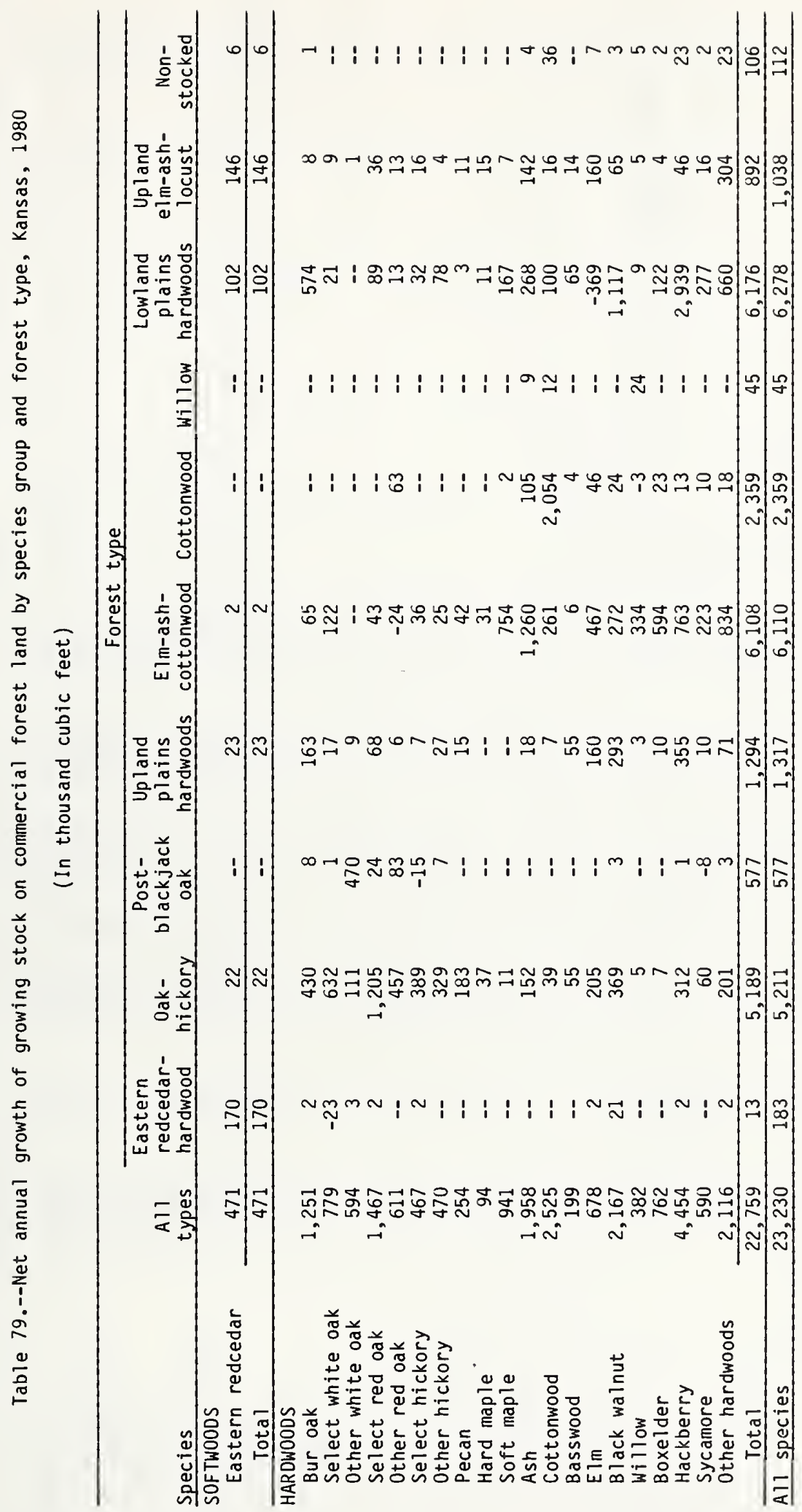




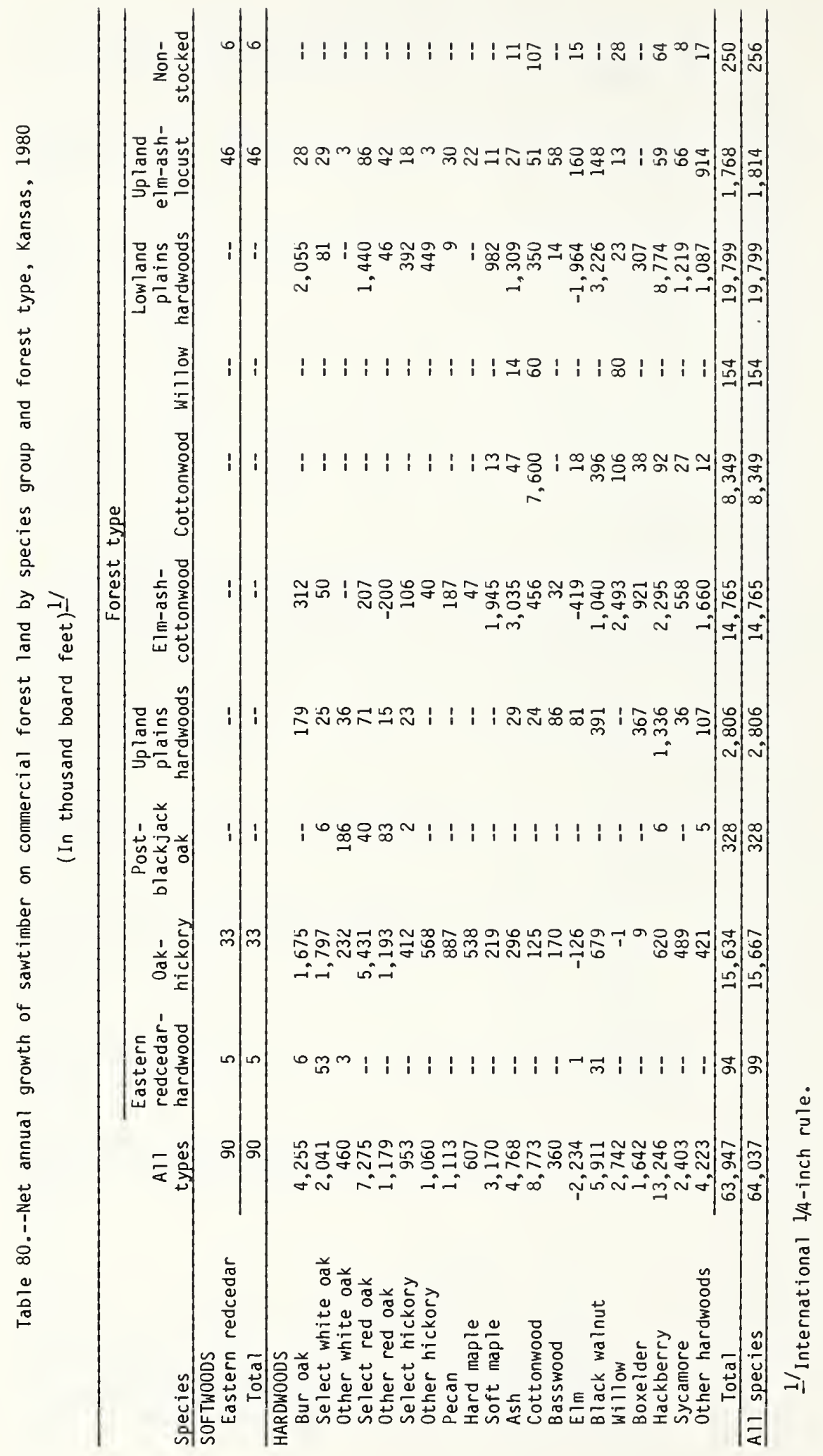



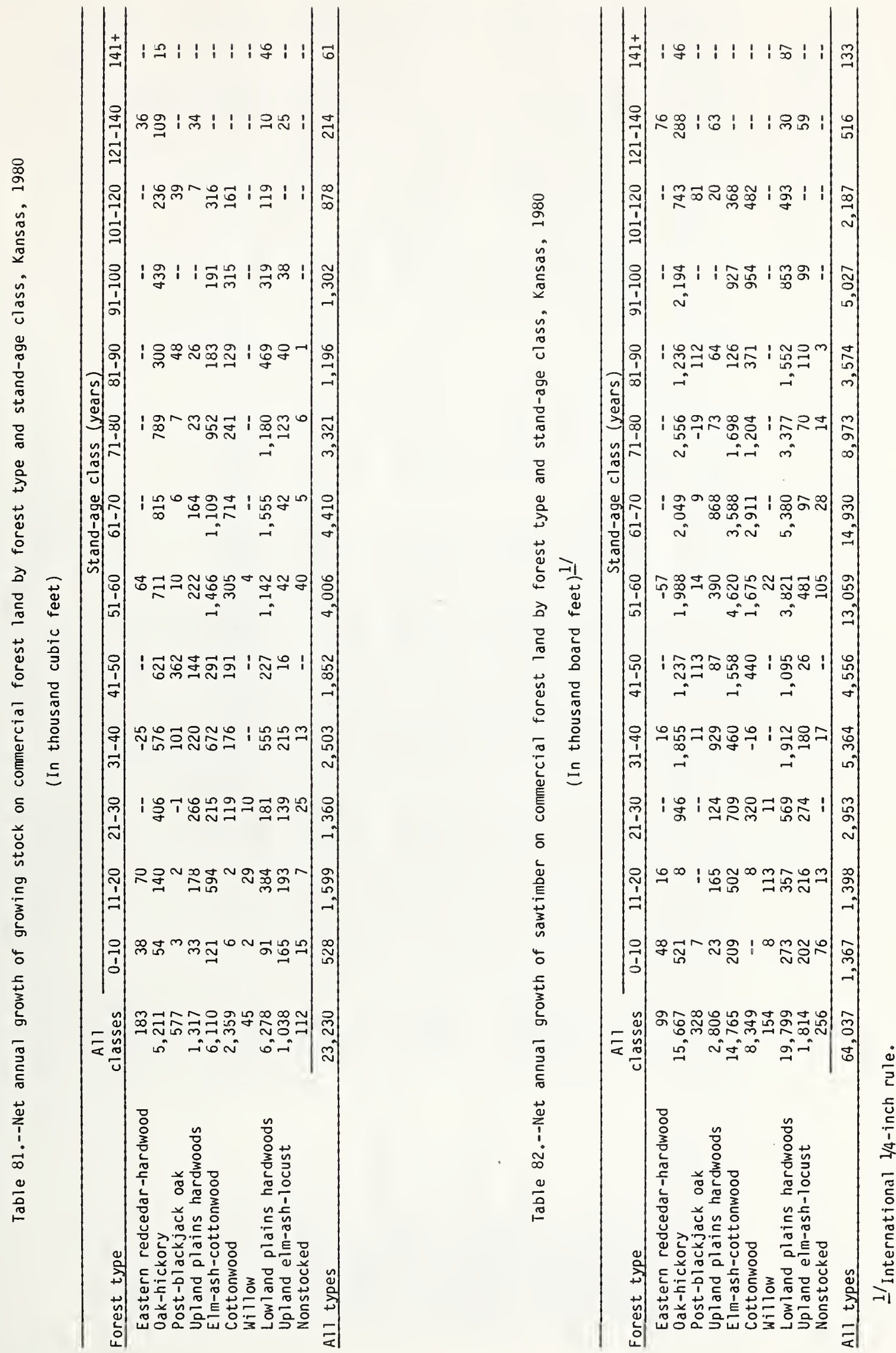


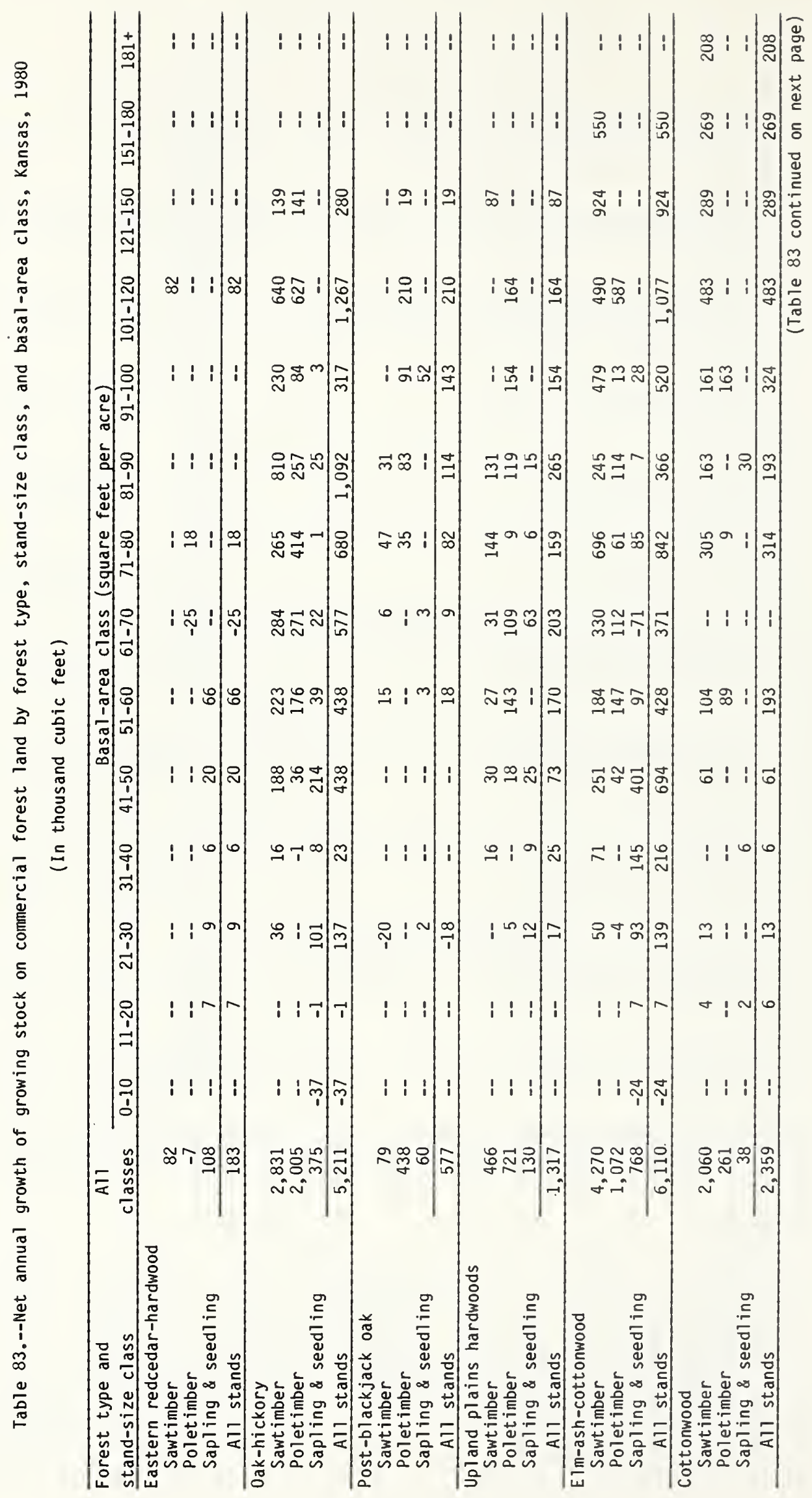




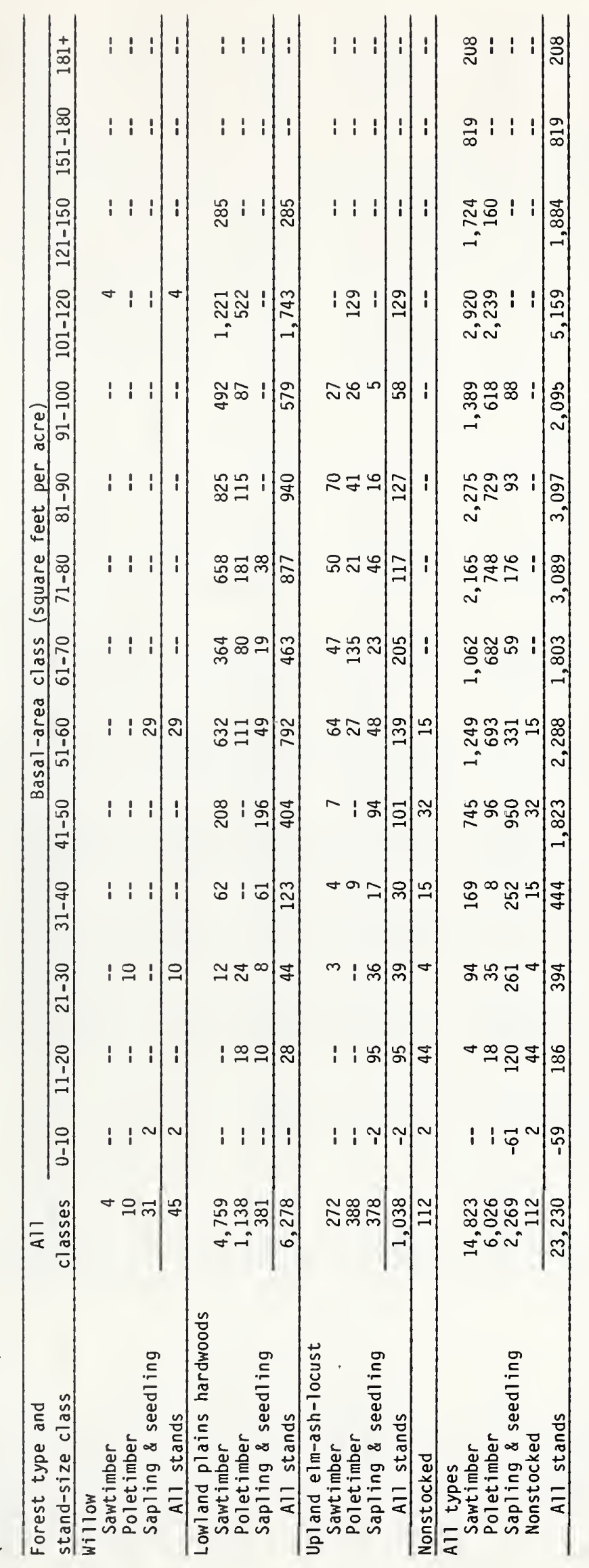




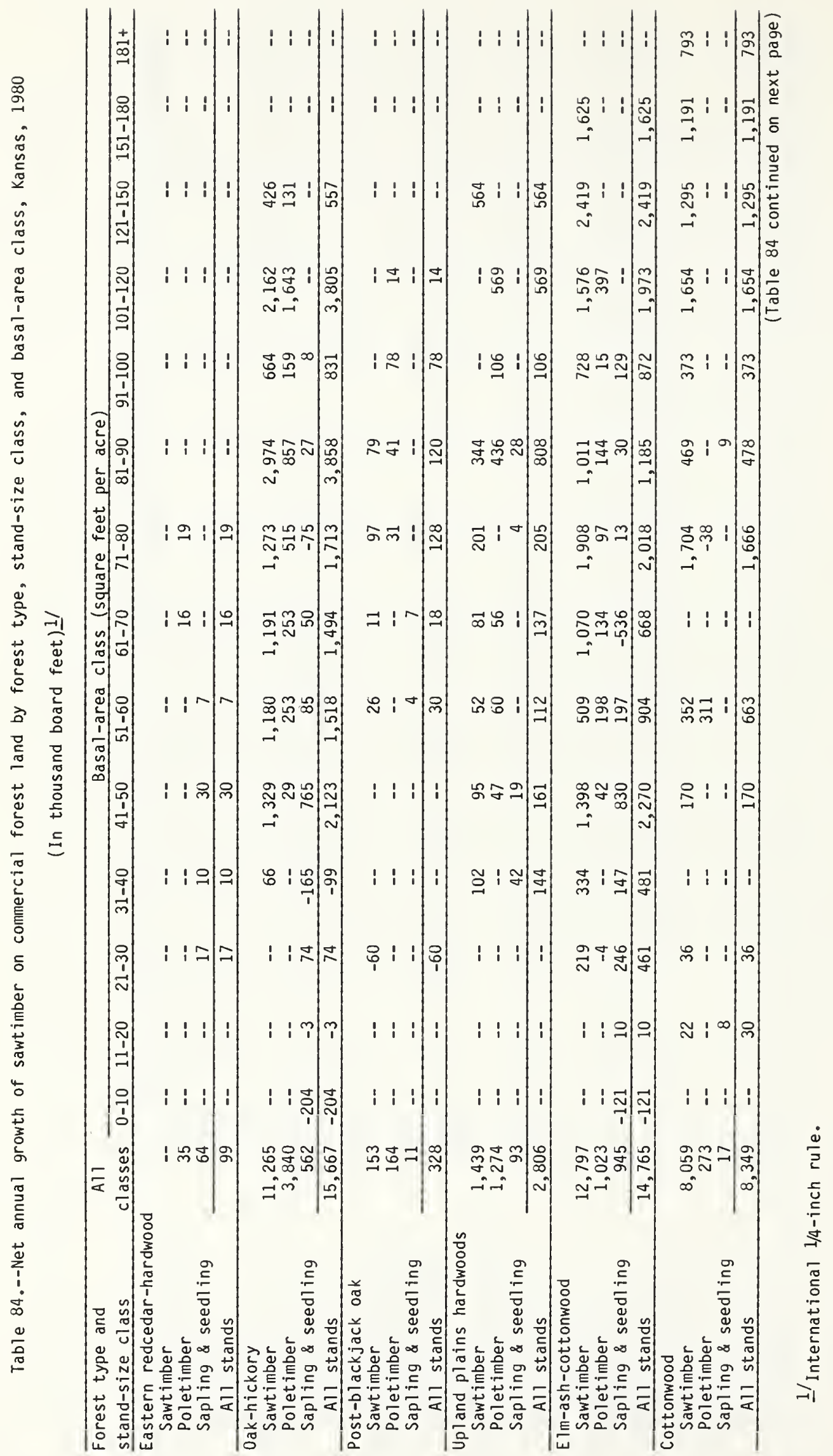




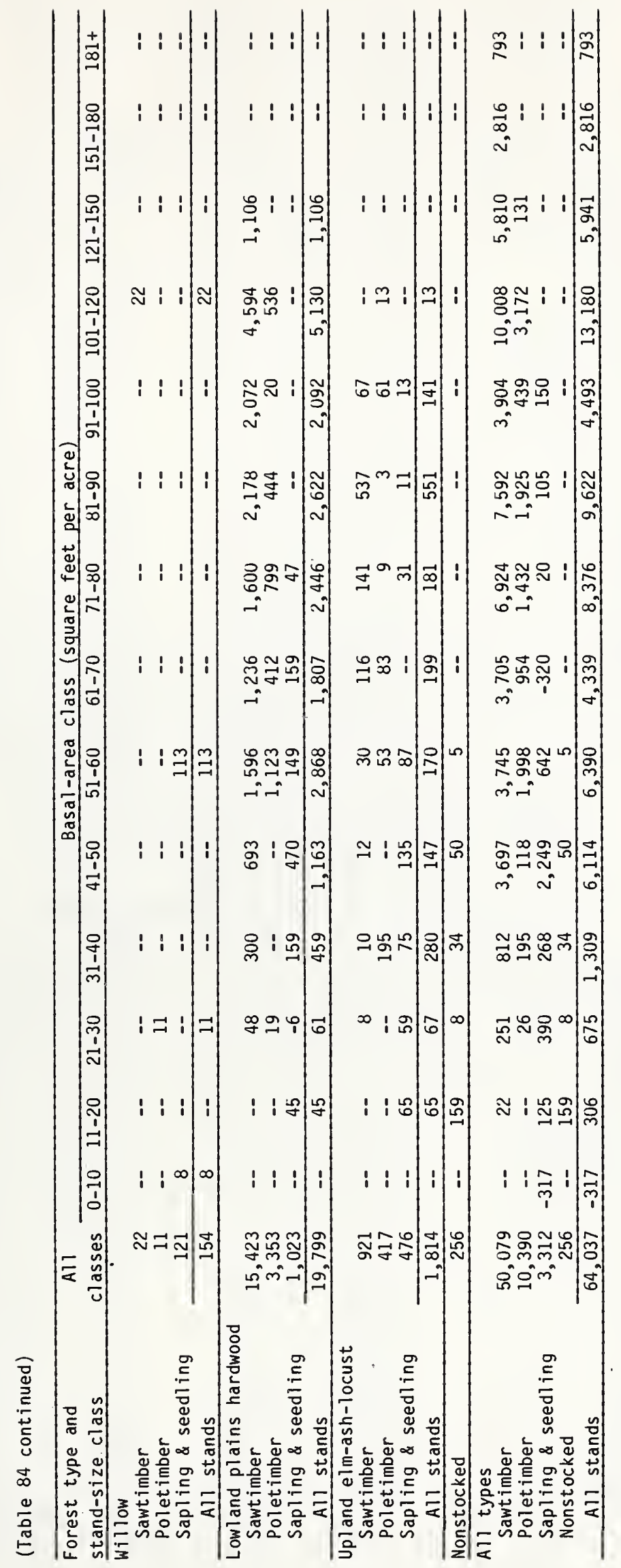


Table 85.--Net annual growth of growing stock on wooded strips by species group and Forest Survey Unit, Kansas, 1980

(In thousand cubic feet)

\begin{tabular}{|c|c|c|c|c|}
\hline \multirow[b]{2}{*}{ Species group } & \multirow[b]{2}{*}{$\begin{array}{l}\text { All } \\
\text { Units }\end{array}$} & \multicolumn{3}{|c|}{ Forest Survey Unit } \\
\hline & & $\begin{array}{l}\text { North- } \\
\text { eastern } \\
\text { Unit }\end{array}$ & $\begin{array}{l}\text { South- } \\
\text { eastern } \\
\text { Unit }\end{array}$ & $\begin{array}{c}\text { Western } \\
\text { Unit }\end{array}$ \\
\hline \multirow{2}{*}{\multicolumn{5}{|c|}{$\begin{array}{l}\text { SOFTWOODS } \\
\text { Eastern redcedar }\end{array}$}} \\
\hline & 107 & 11 & -- & 96 \\
\hline Total & 107 & 11 & -- & 96 \\
\hline \multicolumn{5}{|l|}{ HARDWOODS } \\
\hline Bur oak & 157 & 11 & 21 & 125 \\
\hline Select white oak & 41 & - & 41 & -- \\
\hline Other white oak & -- & -- & -- & -- \\
\hline Select red oak & 45 & 8 & 37 & -- \\
\hline Other red oak & 24 & 9 & 15 & -- \\
\hline Select hickory & 9 & 8 & 1 & -- \\
\hline Other hickory & 22 & 7 & 15 & -- \\
\hline Pecan & 10 & -- & 10 & -- \\
\hline Hard maple & -- & -- & -- & -- \\
\hline Soft maple & 120 & 95 & 25 & -- \\
\hline Ash & 360 & 96 & 70 & 194 \\
\hline Cottonwood & -32 & 92 & -316 & 192 \\
\hline Basswood & 26 & 26 & -- & -- \\
\hline $\mathrm{E} \operatorname{lm}$ & 199 & 128 & 66 & 5 \\
\hline Black walnut & 107 & 75 & 32 & -- \\
\hline Willow & 34 & 20 & 6 & 8 \\
\hline Boxelder & 99 & 71 & 28 & -- \\
\hline Hackberry & 840 & 201 & 411 & 228 \\
\hline Sycamore & 88 & 53 & 35 & -- \\
\hline Other hardwoods & 196 & 153 & 43 & -- \\
\hline Total & 2,345 & 1,053 & 540 & 752 \\
\hline All species & 2,452 & 1,064 & 540 & 848 \\
\hline
\end{tabular}

Table 86.--Net annual growth of sawtimber on wooded strips by species group and Forest Survey Unit, Kansas, 1980

(In thousand board feet) $\underline{1}$ !

\begin{tabular}{|c|c|c|c|c|}
\hline \multirow[b]{2}{*}{ Species group } & \multirow[b]{2}{*}{$\begin{array}{c}\text { All } \\
\text { Units } \\
\end{array}$} & \multicolumn{3}{|c|}{ Forest Survey Unit } \\
\hline & & $\begin{array}{l}\text { North- } \\
\text { eastern } \\
\text { Unit } \\
\end{array}$ & $\begin{array}{r}\text { South- } \\
\text { eastern } \\
\text { Unit } \\
\end{array}$ & $\begin{array}{c}\text { Western } \\
\text { Unit }\end{array}$ \\
\hline \multicolumn{5}{|l|}{ SOFTWOODS } \\
\hline Eastern redcedar & 53 & -- & - & 53 \\
\hline Total & 53 & -- & -- & 53 \\
\hline \multicolumn{5}{|l|}{ HARDWOODS } \\
\hline Bur oak & 581 & 36 & 81 & 464 \\
\hline Select white oak & $=-$ & -- & -- & -- \\
\hline Other white oak & -- & -- & -- & -- \\
\hline Select red oak & 99 & -- & 99 & -- \\
\hline Other red oak & 78 & 52 & 26 & -- \\
\hline Select hickory & -- & -- & - & -- \\
\hline Other hickory & 20 & -- & 20 & -- \\
\hline Pecan & 28 & -- & 28 & -- \\
\hline Hard maple & -- & - & -- & -- \\
\hline Soft maple & 221 & 174 & 47 & -- \\
\hline Ash & 1,272 & 865 & 90 & 317 \\
\hline Cottonwood & 1,806 & 802 & -624 & 1,628 \\
\hline Basswood & 12 & 12 & -- & - \\
\hline Elm & 154 & 72 & 82 & -- \\
\hline Black walnut & 180 & 137 & 43 & -- \\
\hline Willow & 1,690 & 531 & 27 & 1,132 \\
\hline Boxelder & 159 & 44 & 115 & -- \\
\hline Hackberry & 2,178 & 730 & 1,173 & 275 \\
\hline Sycamore & 186 & 60 & 126 & -- \\
\hline Other hardwoods & 488 & 356 & 132 & - \\
\hline Total & 9,152 & 3,871 & 1,465 & 3,816 \\
\hline All species & 9,205 & 3,871 & 1,465 & 3,869 \\
\hline
\end{tabular}

1/ International $1 / 4-i$ nch rule. 
Table 87.--Timber removals from growing stock on commercial forest

land, by species group and Forest Survey Unit, Kansas, 1980

(In thousand cubic feet)

\begin{tabular}{|c|c|c|c|c|}
\hline \multirow[b]{2}{*}{ Species group } & \multirow[b]{2}{*}{$\begin{array}{c}\text { Al1 } \\
\text { Units }\end{array}$} & \multicolumn{3}{|c|}{ Forest Survey Unit } \\
\hline & & $\begin{array}{c}\text { North- } \\
\text { eastern } \\
\text { Unit } \\
\end{array}$ & $\begin{array}{c}\text { South- } \\
\text { eastern } \\
\text { Unit } \\
\end{array}$ & $\begin{array}{c}\text { Western } \\
\text { Unit }\end{array}$ \\
\hline \multirow{2}{*}{\multicolumn{5}{|c|}{$\begin{array}{l}\text { SOFTW00DS } \\
\text { Eastern redcedar }\end{array}$}} \\
\hline & 89 & 40 & 14 & 35 \\
\hline Total & 89 & 40 & 14 & 35 \\
\hline \multicolumn{5}{|l|}{ HARDWOODS } \\
\hline Bur oak & 1,303 & 604 & 360 & 339 \\
\hline Select white oak & 700 & 434 & 266 & -- \\
\hline Other white oak & 480 & 41 & 439 & -- \\
\hline Select red oak & 1,195 & 573 & 604 & 18 \\
\hline Other red oak & 703 & 341 & 362 & -- \\
\hline Select hickory & 168 & 115 & 53 & -- \\
\hline Other hickory & 106 & 58 & 48 & -- \\
\hline Pecan & 85 & -- & 85 & -- \\
\hline Hard maple & 15 & 3 & 12 & -- \\
\hline Soft maple & 500 & 201 & 297 & 2 \\
\hline Ash & 1,629 & 451 & 888 & 290 \\
\hline Cottonwood & 1,935 & 893 & 559 & 483 \\
\hline Basswood & 17 & 17 & -- & -- \\
\hline Elm & 685 & 280 & 337 & 68 \\
\hline Black walnut & 1,307 & 787 & 508 & 12 \\
\hline Hackberry & 1,220 & 437 & 672 & 111 \\
\hline Sycamore & 320 & 70 & 237 & 13 \\
\hline Other hardwoods $1 /$ & 1,526 & 694 & 530 & 302 \\
\hline Total & 13,894 & 5,999 & 6,257 & 1,638 \\
\hline All species & 13,983 & 6,039 & 6,271 & 1,673 \\
\hline
\end{tabular}

1/Includes willow and boxelder species groups.

Table 88.--Timber removals from sawtimber on commercial forest

land, by species group and Forest Survey Unit, Kansas, 1980

(In thousand board feet) 1 /

\begin{tabular}{|c|c|c|c|c|}
\hline \multirow[b]{2}{*}{ Species group } & \multirow[b]{2}{*}{$\begin{array}{c}\text { All } \\
\text { Units }\end{array}$} & \multicolumn{3}{|c|}{ Forest Survey Unit } \\
\hline & & $\begin{array}{l}\text { North- } \\
\text { eastern } \\
\text { Unit }\end{array}$ & $\begin{array}{l}\text { South- } \\
\text { eastern } \\
\text { Unit }\end{array}$ & $\begin{array}{c}\text { Western } \\
\text { Unit }\end{array}$ \\
\hline \multicolumn{5}{|l|}{ SOF TWOODS } \\
\hline Eastern redcedar & 324 & 132 & 30 & 162 \\
\hline Total & 324 & 132 & 30 & 162 \\
\hline \multicolumn{5}{|l|}{ HARDWOODS } \\
\hline Bur oak & 4,771 & 2,002 & 1,721 & 1,048 \\
\hline Select white oak & 1,881 & 1,203 & 678 & $\ldots$ \\
\hline Other white oak & 830 & 94 & 736 & -- \\
\hline Select red oak & 3,529 & 1,620 & 1,832 & 77 \\
\hline Other red oak & 2,199 & 1,082 & 1,117 & -- \\
\hline Select hickory & 527 & 344 & 183 & - \\
\hline Other hickory & 257 & 157 & 100 & -- \\
\hline Pecan & 394 & 4 & 389 & 1 \\
\hline Hard maple & 41 & 8 & 33 & -- \\
\hline Soft maple & 2,126 & 699 & 1,422 & 5 \\
\hline Ash & 5,484 & 1,538 & 3,058 & 888 \\
\hline Cottonwood & 9,154 & 4,334 & 3,146 & 1,674 \\
\hline Basswood & 66 & 65 & 1 & -- \\
\hline Elm & 2,538 & 936 & 1,362 & 240 \\
\hline Black walnut & 8,281 & 4,977 & 3,204 & 100 \\
\hline Hackberry & 4,890 & 1,585 & 2,879 & 426 \\
\hline Sycamore & 1,611 & 321 & 1,220 & 70 \\
\hline Other hardwoods -7 & 4,350 & 1,951 & 1,504 & 895 \\
\hline Total & 52,929 & 22,920 & 24,585 & 5,424 \\
\hline All species & 53,253 & 23,052 & 24,615 & 5,586 \\
\hline
\end{tabular}

$1 /$ International 1/4-inch rule.

2/Includes willow and boxelder species groups. 
Table 89.--Timber removals $1 /$ from growing stock and sawtimber on commercial forest land by species group, Kansas, 1964 and 1980

\begin{tabular}{|c|c|c|c|c|}
\hline \multirow[b]{2}{*}{ Species group } & \multicolumn{2}{|c|}{ Growing stock } & \multicolumn{2}{|c|}{ Sawtimber } \\
\hline & 19642 & 1980 & $1964^{21}$ & 1980 \\
\hline & \multicolumn{2}{|c|}{ Thousand cubic feet } & \multicolumn{2}{|c|}{ Thous and board feet $3 /$} \\
\hline \multicolumn{5}{|l|}{ SOFTWOODS } \\
\hline Eastern redcedar & 21 & 89 & -- & 324 \\
\hline Total & 21 & 89 & $=$ & 324 \\
\hline \multicolumn{5}{|l|}{ HARDWOODS } \\
\hline Bur oak & 953 & 1,303 & 3,604 & 4,771 \\
\hline Select white oak & 120 & 700 & 502 & 1,881 \\
\hline Other white oak & 295 & 480 & 493 & 830 \\
\hline Select red oak & 156 & 1,195 & 169 & 3,529 \\
\hline Other red oak & 492 & 703 & 1,455 & 2,199 \\
\hline Select hickory & 330 & 168 & 981 & 527 \\
\hline Other hickory & 209 & 106 & 479 & 257 \\
\hline Pecan & 72 & 85 & 257 & 394 \\
\hline Hard maple & 12 & 15 & 4 & 41 \\
\hline Soft maple & 667 & 500 & 2,732 & 2,126 \\
\hline Ash & 607 & 1,629 & 1,550 & 5,484 \\
\hline Cottonwood & 1,120 & 1,935 & 4,183 & 9,154 \\
\hline Basswood & 19 & 17 & & 66 \\
\hline Elm & 848 & 685 & 2,539 & 2,538 \\
\hline Black walnut & 1,180 & 1,307 & 7,240 & 8,281 \\
\hline Hackberry & 626 & 1,220 & 2,351 & 4,890 \\
\hline Sycamore & 259 & 320 & 903 & 1,611 \\
\hline Other hardwoods 4 - & 314 & 1,526 & 547 & 4,350 \\
\hline Total & 8,279 & 13,894 & 30,000 & 52,929 \\
\hline A11 species & 8,300 & 13,983 & 30,000 & 53,253 \\
\hline
\end{tabular}

1 'Removals in 1980 are trend-level removals.

2/Figures have been adjusted from those published after the 1966 survey to conform to 1980 volumes because of changes in survey definitions and procedures.

3/ International $1 / 4$-inch rule.

4/ Includes willow and boxelder species groups. 
Table 90.--Timber removals from growing stock and sawtimber on commercial forest land by item and species category, Kansas, 1980

GROWING STOCK

\begin{tabular}{|c|c|c|c|c|c|c|c|c|}
\hline \multirow[b]{2}{*}{ Item } & \multirow[b]{2}{*}{$\begin{array}{c}\text { All } \\
\text { species }\end{array}$} & \multicolumn{7}{|c|}{ Species category } \\
\hline & & Softwoods & Oak & $\begin{array}{c}\text { Elm- } \\
\text { hackberry }\end{array}$ & Ash & Cottonwood & Walnut & $\begin{array}{c}\text { Other } \\
\text { hardwoods }\end{array}$ \\
\hline ROUNDWOOD PRODUCTS & $-\cdot-$ & $-\cdots$ & - - - & -Thousand & ubic $f$ & $-\cdots \cdots$ & --- & $-\cdots-$ \\
\hline Saw logs & 4,340 & 66 & 730 & 638 & 336 & 940 & 1,138 & 492 \\
\hline Veneer logs & & -- & 12 & -- & - & -- & 60 & -- \\
\hline Cooperage logs & & -- & 40 & -- & -- & -- & -- & -- \\
\hline Fuelwood & 7,577 & -- & 3,184 & 1,033 & 1,034 & 398 & -- & 1,928 \\
\hline Posts & & 18 & 19 & -- & -- & $=-$ & $=-$ & 15 \\
\hline Total & 12,081 & 84 & 3,985 & 1,671 & 1,370 & 1,338 & 1,198 & 2,435 \\
\hline LOGGING RES IDUE & 755 & $=$ & 231 & 69 & 137 & 140 & 109 & 69 \\
\hline OTHER REMOVALS & 1,147 & 5 & 165 & 165 & 122 & 457 & $\because$ & 233 \\
\hline ALL TIMBER REMOVALS & 13,983 & 89 & 4,381 & 1,905 & 1,629 & 1,935 & 1,307 & 2,737 \\
\hline \multicolumn{9}{|c|}{ SAWT IMBER } \\
\hline ROUNDWOOD PRODUCTS & $--\cdot$ & $--\cdot$ & & & & & & --- \\
\hline Saw logs & 26,269 & 312 & 3,358 & 4,017 & 1,991 & 6,107 & 7,431 & 3,053 \\
\hline Veneer logs & 475 & -- & 59 & -- & -- & -- & 416 & -- \\
\hline Cooperage logs & 237 & -- & 237 & -- & -- & -- & -- & -- \\
\hline Fuelwood & 20,895 & -- & 8,773 & 2,850 & $2,8 b 1$ & 1,097 & -- & 5,324 \\
\hline Posts & 114 & 11 & 62 & -- & -- & -- & -- & 41 \\
\hline Total & 47,990 & 323 & 12,489 & 6,867 & 4,842 & 7,204 & 7,847 & 8,418 \\
\hline LOGGING RES IDUE & 1,637 & -- & 327 & 125 & 315 & 293 & 434 & 143 \\
\hline OTHER REMOVALS & 3,626 & 1 & 394 & 436 & 327 & 1,657 & - & 811 \\
\hline ALL TIMBER REMOVALS & 53,253 & 324 & 13,210 & 7,428 & 5,484 & 9,154 & 8,281 & 9,372 \\
\hline
\end{tabular}

$1 /$ International $1 / 4$-inch rule.

Table 91.--Net annual growth and removais of growing stock on commercial forest land by species group, Kansas, 1980

(In thousand cubic feet)

\begin{tabular}{lrr}
\hline Species group & $\begin{array}{r}\text { Net annual } \\
\text { growth }\end{array}$ & $\begin{array}{c}\text { Annual timber } \\
\text { removals }\end{array}$ \\
\hline SofTw00DS & & \\
Eastern redcedar & 471 & 89 \\
$\quad$ Total & & \\
\hline HARDW00DS & 1,251 & 1,303 \\
Bur oak & 779 & 700 \\
Select white oak & 594 & 480 \\
Other white oak & 1,467 & 1,195 \\
Select red oak & 611 & 703 \\
Other red oak & 467 & 168 \\
Select hickory & 470 & 106 \\
Other hickory & 254 & 85 \\
Pecan & 94 & 15 \\
Hard maple & 941 & 500 \\
Soft maple & 1,958 & 1,629 \\
Ash & 2,525 & 1,935 \\
Cottonwood & 199 & 17 \\
Basswood & 678 & 685 \\
Elm & 2,167 & 1,307 \\
Black walnut & 4,454 & 1,220 \\
Hackberry & 590 & 320 \\
Sycamore & 3,260 & 1,526 \\
Other hardwoods $1 /$ & 22,759 & 13,894 \\
Total & 23,230 & 13,983 \\
\hline All species & & \\
\hline
\end{tabular}

IIInciudes willow and boxelder species groups. 
Table 92.--Net annual growth and removals of sawtimber on commercial forest land by species group, Kansas, 1980

(In thousand board feet) $\underline{\text { l/ }}$

\begin{tabular}{lrr}
\hline Species group & $\begin{array}{r}\text { Net annual } \\
\text { growth }\end{array}$ & $\begin{array}{c}\text { Annual timber } \\
\text { removals }\end{array}$ \\
\hline SOFTw00DS & 90 & 324 \\
Eastern redcedar & 90 & 324 \\
$\quad$ Total & & \\
\hline HARDWOODS & 4,255 & 4,771 \\
Bur oak & 2,041 & 1,881 \\
Select white oak & 460 & 830 \\
Other white oak & 7,275 & 3,529 \\
Select red oak & 1,179 & 2,199 \\
Other red oak & 953 & 527 \\
Select hickory & 1,060 & 257 \\
Other hickory & 1,113 & 394 \\
Pecan & 607 & 41 \\
Hard maple & 3,170 & 2,126 \\
Soft maple & 4,768 & 5,484 \\
Ash & 8,773 & 9,154 \\
Cottonwood & 360 & 66 \\
Basswood & $-2,234$ & 2,538 \\
Elm & 5,911 & 8,281 \\
Black walnut & 13,246 & 4,890 \\
Hackberry & 2,403 & 1,611 \\
Sycamore & 8,607 & 4,350 \\
Other hardwoods & 63,947 & 52,929 \\
Total & 64,037 & 53,253 \\
\hline All species & & \\
\hline
\end{tabular}

$1 /$ International $1 / 4$-inch rule.

2/Includes willow and boxelder species groups.

Table 93.--Net annual growth and removals of growing stock on commercial forest land by ownership class and softwoods and hardwoods, Kansas, 1980

(In thousand cubic feet)

\begin{tabular}{|c|c|c|c|c|c|c|}
\hline \multirow[b]{2}{*}{ Ownership class } & \multicolumn{3}{|c|}{ Net annual growth } & \multicolumn{3}{|c|}{ Annual timber removals } \\
\hline & $\begin{array}{c}\text { All } \\
\text { species }\end{array}$ & Softwoods & Hardwoods & $\begin{array}{c}A 11 \\
\text { species }\end{array}$ & Softwoods & Hardwoods \\
\hline \multicolumn{7}{|l|}{ PUBLIC } \\
\hline National Forest & -- & -- & -- & -- & -- & -- \\
\hline Misc. federal & 1,020 & 2 & 1,018 & 13 & -- & 13 \\
\hline Indian & 25 & -- & 25 & 6 & -- & 6 \\
\hline State & 316 & -- & 316 & -- & -- & -- \\
\hline County \& municipal & 152 & -- & 152 & - & -- & -- \\
\hline Total & 1,513 & 2 & 1,511 & 19 & -- & 19 \\
\hline \multicolumn{7}{|l|}{$\overline{\text { PRIVATE }}$} \\
\hline $\begin{array}{l}\text { Farmer and } \\
\text { Misc. private }\end{array}$ & 21,717 & 469 & 21,248 & 13,964 & 89 & 13,875 \\
\hline All owners & 23,230 & 471 & 22,759 & 13,983 & 89 & 13,894 \\
\hline
\end{tabular}


Table 94.--Net annual growth and removals of sawtimber on commercial forest land by ownership class and softwoods and hardwoods, Kansas, 1980

(In thousand board feet) $\underline{1 /}$

\begin{tabular}{|c|c|c|c|c|c|c|}
\hline \multirow[b]{2}{*}{ Ownership class } & \multicolumn{3}{|c|}{ Net annual growth } & \multicolumn{3}{|c|}{ Annual timber removals } \\
\hline & $\begin{array}{c}\text { All } \\
\text { species }\end{array}$ & Softwoods & Hardwoods & $\begin{array}{c}\text { All } \\
\text { species }\end{array}$ & Softwoods & Hardwoods \\
\hline \multicolumn{7}{|l|}{ PUBLIC } \\
\hline National Forest & -- & -- & -- & -- & -- & -- \\
\hline Misc. federal & 2,658 & -- & 2,658 & 33 & -- & 33 \\
\hline Indian & 59 & -- & 59 & 17 & -- & 17 \\
\hline State & 866 & -- & 866 & -- & -- & -- \\
\hline County \& municipal & 988 & -- & 988 & - & -- & -- \\
\hline Total & 4,571 & - & 4,571 & 50 & -- & 50 \\
\hline $\begin{array}{l}\text { PRIVATE } \\
\text { Farmer and } \\
\text { Misc. private }\end{array}$ & 59,466 & 90 & 59,376 & 53,203 & 324 & 52,879 \\
\hline All owners & 64,037 & 90 & 63,947 & 53,253 & 324 & 52,929 \\
\hline
\end{tabular}

1/International $1 / 4$-inch rule.

Table 95.--Annual mortality of growing stock on commercial forest land by softwoods and hardwoods, Kansas, 1964 and 1980

(In thousand cubic feet)

\begin{tabular}{lrr}
\hline Species & 1964 1/ & 1980 \\
\hline Softwoods & -- & 28 \\
Hardwoods & 3,280 & 3,739 \\
\hline Al1 species & 3,280 & 3,767 \\
\hline
\end{tabular}

$1 /$ Figures have been adjusted from those published after the 1965 survey to conform to 1980 volumes because of changes in survey definitions and procedures. 
Table 96.--Annual mortality of growing stock on commercial forest land by species group and cause, Kansas, 1980

(In thousand cubic feet)

\begin{tabular}{|c|c|c|c|c|c|c|c|c|}
\hline \multirow[b]{2}{*}{ Species group } & \multirow[b]{2}{*}{$\begin{array}{c}\text { A11 } \\
\text { causes }\end{array}$} & \multicolumn{7}{|c|}{ Cause } \\
\hline & & Insects & Disease & Fire & Animals & Weather & Suppression & $\begin{array}{l}\text { Unknown } \\
\text { and other }\end{array}$ \\
\hline \multirow{2}{*}{\multicolumn{9}{|c|}{$\begin{array}{l}\text { SOF TWOODS } \\
\text { Eastern redcedar }\end{array}$}} \\
\hline & 28 & -- & - & -- & -- & $\because$ & 28 & - \\
\hline Tota 1 & 28 & $=-$ & -- & -- & $=$ & $=$ & 28 & -- \\
\hline \multicolumn{9}{|l|}{ HARDWOODS } \\
\hline Bur oak & 220 & -- & 117 & 4 & - & 6 & -- & 93 \\
\hline Select white oak & 94 & -- & 22 & -- & 28 & - & -- & 44 \\
\hline other white oak & 46 & -- & -- & 12 & -- & -- & -- & 34 \\
\hline Select red oak & 210 & -- & 77 & -- & -- & 42 & -- & 91 \\
\hline Other red oak & 216 & -- & 115 & -- & -- & 52 & -- & 49 \\
\hline Select hickory & 39 & -- & 29 & -- & -- & -- & -- & 10 \\
\hline Other hickory & 10 & -- & 7 & -- & -- & -- & -- & 3 \\
\hline Pecan & - & -- & -- & -- & -- & - & -- & -- \\
\hline Hard maple & -- & -- & -- & -- & -- & -- & -- & -- \\
\hline Soft maple & 12 & -- & -- & -- & -- & - & -- & 12 \\
\hline Ash & 177 & -- & 20 & -- & -- & 10 & 3 & 144 \\
\hline Cottonwood & 853 & 122 & 91 & -- & 66 & 153 & -- & 421 \\
\hline Basswood & 6 & -- & 6 & -- & -- & -- & - & -- \\
\hline Elm & 1,283 & 7 & 865 & 8 & -- & 27 & -- & 376 \\
\hline Black walnut & 223 & -- & 55 & 5 & -- & - & -- & 163 \\
\hline Willow & 57 & -- & 17 & -- & -- & -- & -- & 40 \\
\hline Boxelder & 40 & -- & -- & -- & -- & 35 & 5 & -- \\
\hline Hackberry & 158 & -- & 93 & 6 & -- & -- & -- & 59 \\
\hline Sycamore & 69 & -- & -- & -- & - & -- & -- & 69 \\
\hline Other hardwoods & 26 & $=-$ & -- & -- & -- & -- & - & 26 \\
\hline Total & 3,739 & 129 & 1,514 & 35 & 94 & 325 & 8 & 1,634 \\
\hline All species & 3,767 & 129 & 1,514 & 35 & 94 & 325 & 36 & 1,634 \\
\hline
\end{tabular}


Table 97.--Annual mortality of sawtimber on commercial forest land by species group and cause, Kansas, 1980

(In thousand board feet) 1 I

\begin{tabular}{|c|c|c|c|c|c|c|c|c|}
\hline \multirow[b]{2}{*}{ Species group } & \multirow[b]{2}{*}{$\begin{array}{c}\text { All } \\
\text { causes }\end{array}$} & \multicolumn{7}{|c|}{ Cause } \\
\hline & & Insects & Disease & Fire & Animals & Weather & Suppression & $\begin{array}{l}\text { Unknown } \\
\text { and other }\end{array}$ \\
\hline \multicolumn{9}{|l|}{ SOFTWOODS } \\
\hline Eastern redcedar & 157 & -- & -- & -- & -- & -- & 157 & - \\
\hline Total & 157 & -- & -- & -- & -- & -- & 157 & - \\
\hline \multicolumn{9}{|l|}{ HARDWOODS } \\
\hline Bur oak & 484 & -- & 119 & 21 & -- & 28 & -- & 316 \\
\hline Select white oak & 247 & -- & 93 & -- & 133 & -- & -- & 21 \\
\hline Other white oak & 91 & -- & -- & 23 & - & -- & -- & 68 \\
\hline Select red oak & 660 & -- & 356 & -- & -- & 174 & -- & 130 \\
\hline Other red oak & 1,145 & -- & 624 & -- & -- & 292 & -- & 229 \\
\hline Select hickory & 71 & -- & 26 & -- & -- & - & -- & 45 \\
\hline Other hickory & 34 & -- & 34 & -- & -- & -- & -- & - \\
\hline Pecan & -- & -- & - & -- & -- & -- & -- & -- \\
\hline Hard maple & -- & -- & -- & -- & -- & -- & -- & -- \\
\hline Soft maple & 56 & -- & -- & -- & -- & -- & -- & 56 \\
\hline Ash & 716 & -- & 89 & -- & -- & 48 & -- & 579 \\
\hline Cottonwood & 2,651 & 614 & 371 & -- & 332 & 459 & -- & 875 \\
\hline Basswood & & -- & -- & -- & -- & -- & -- & \\
\hline Elm & 4,295 & 30 & 2,944 & -- & -- & 126 & -- & 1,195 \\
\hline Black walnut & 773 & -- & 135 & 26 & -- & -- & -- & 612 \\
\hline Willow & 85 & -- & 85 & -- & -- & -- & -- & - \\
\hline Boxelder & -- & -- & -- & -- & -- & -- & -- & -- \\
\hline Hackberry & 599 & -- & 397 & 30 & -- & -- & -- & 172 \\
\hline Sycamore & 195 & - & -- & -- & -- & - & -- & 195 \\
\hline Other hardwoods & 60 & - & -- & -- & -- & -- & -- & 60 \\
\hline Total & 12,162 & 644 & 5,273 & 100 & 465 & 1,127 & - & 4,553 \\
\hline All species & 12,319 & 644 & 5,273 & 100 & 465 & 1,127 & 157 & 4,553 \\
\hline
\end{tabular}

I/International $1 / 4$-inch rule.

Table 98.--Annual mortality of growing stock and sawtimber on commercial forest land by ownership class and softwoods and hardwoods, Kansas, 1980

\begin{tabular}{|c|c|c|c|c|c|c|}
\hline \multirow[b]{2}{*}{ Ownership class } & \multicolumn{3}{|c|}{ Growing stock } & \multicolumn{3}{|c|}{ Sawt imber } \\
\hline & $\begin{array}{c}\text { All } \\
\text { species }\end{array}$ & Softwoods & Hardwoods & $\begin{array}{c}\text { All } \\
\text { species }\end{array}$ & Sof twoods & Hardwoods \\
\hline & $\ldots$ & us and cubi & t- - - & $\ldots$. & sand board & $1 / \ldots$ \\
\hline National Forest & -- & -- & -- & -- & -- & -- \\
\hline Miscellaneous federal & 36 & -- & 36 & 127 & -- & 127 \\
\hline Indian & -- & -- & -- & -- & -- & -- \\
\hline State & -- & -- & - & -- & -- & -- \\
\hline County and municipal & & -- & -- & -- & $=$ & -- \\
\hline Farmer & 2,027 & 28 & 1,999 & 7,104 & 157 & 6,947 \\
\hline Misc. private & 1,704 & $=$ & 1,704 & 5,088 & -- & 5,088 \\
\hline All owners & 3,767 & 28 & 3,739 & 12,319 & 157 & 12,162 \\
\hline
\end{tabular}

1/International $1 / 4$-inch rule. 


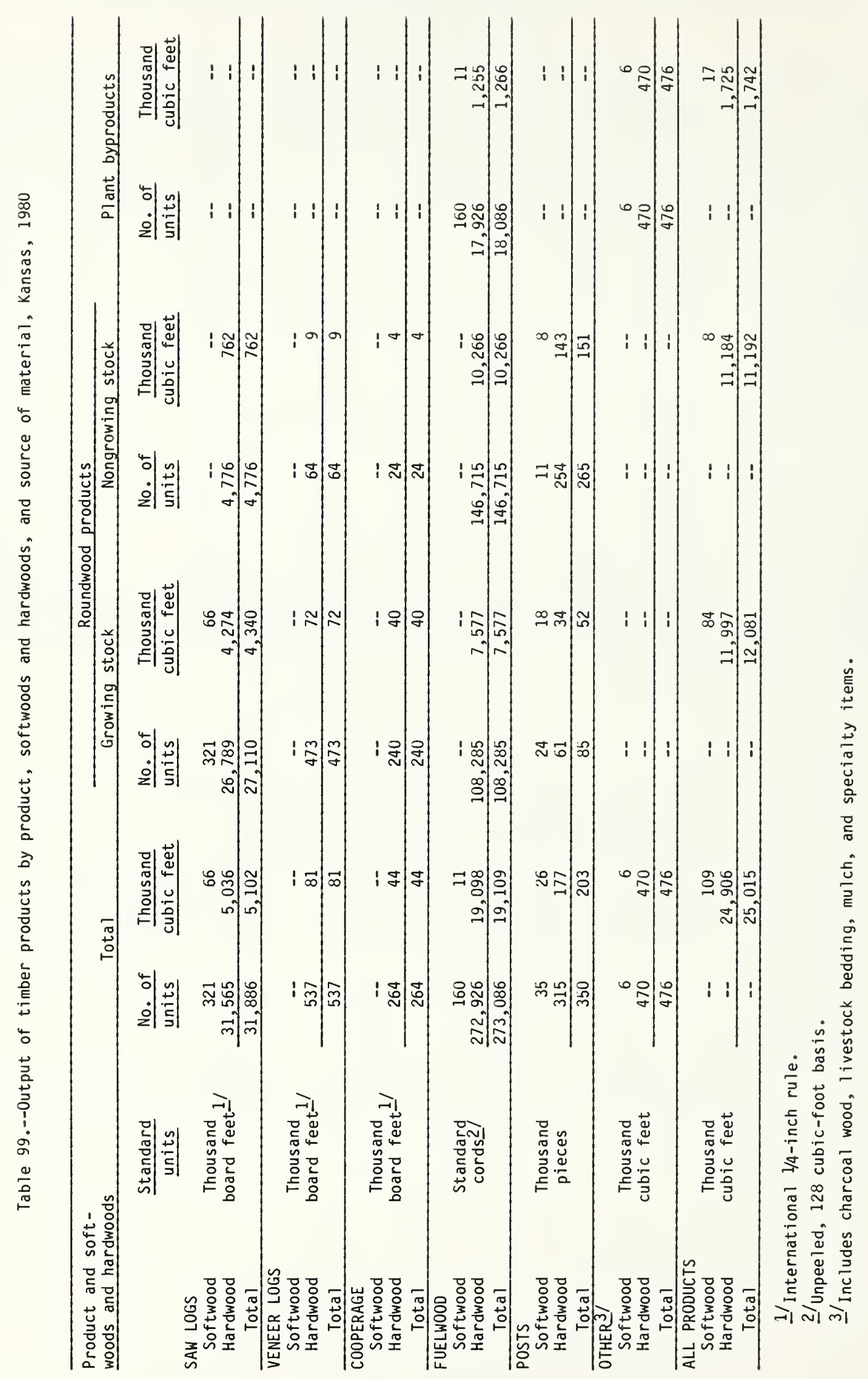




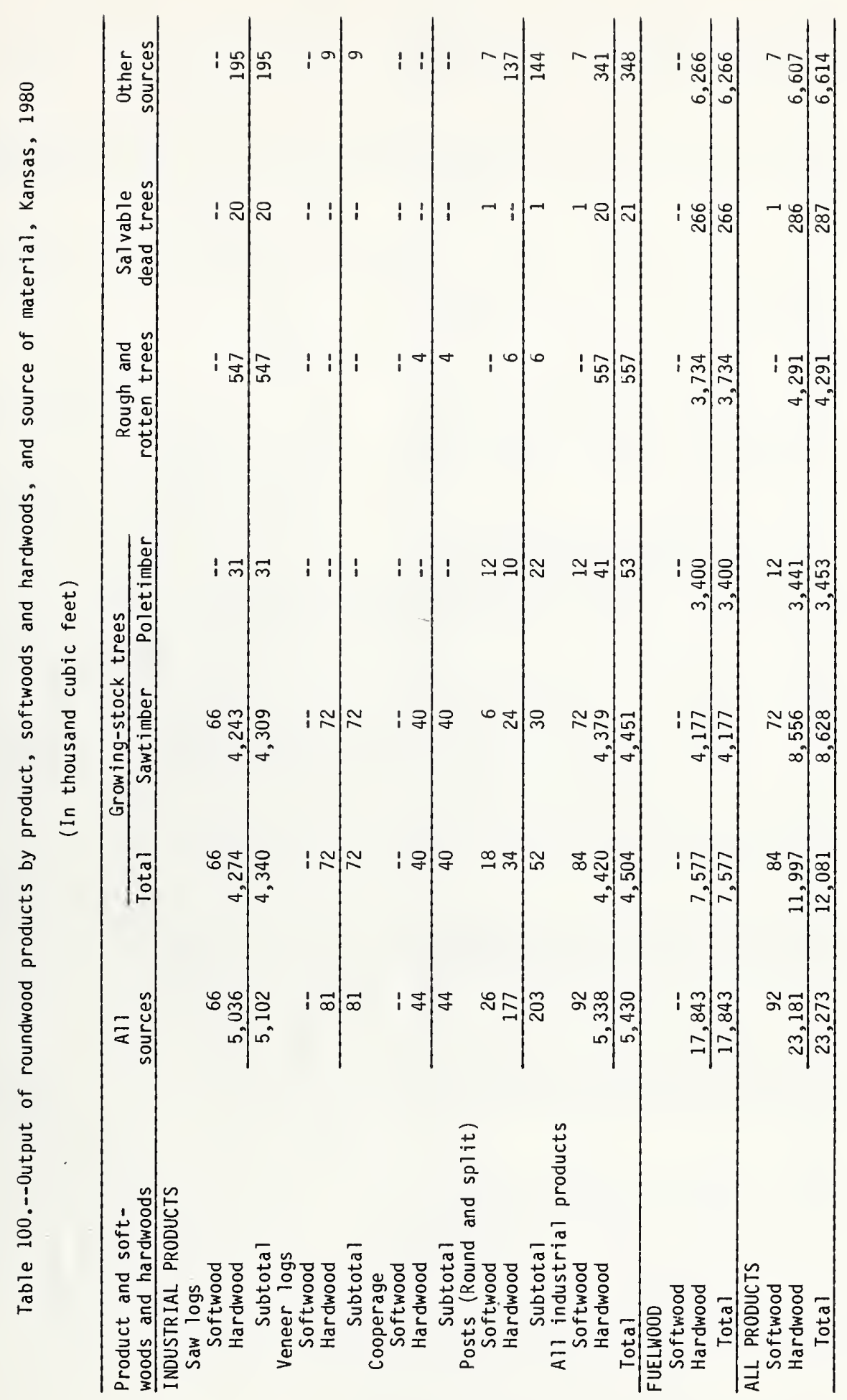




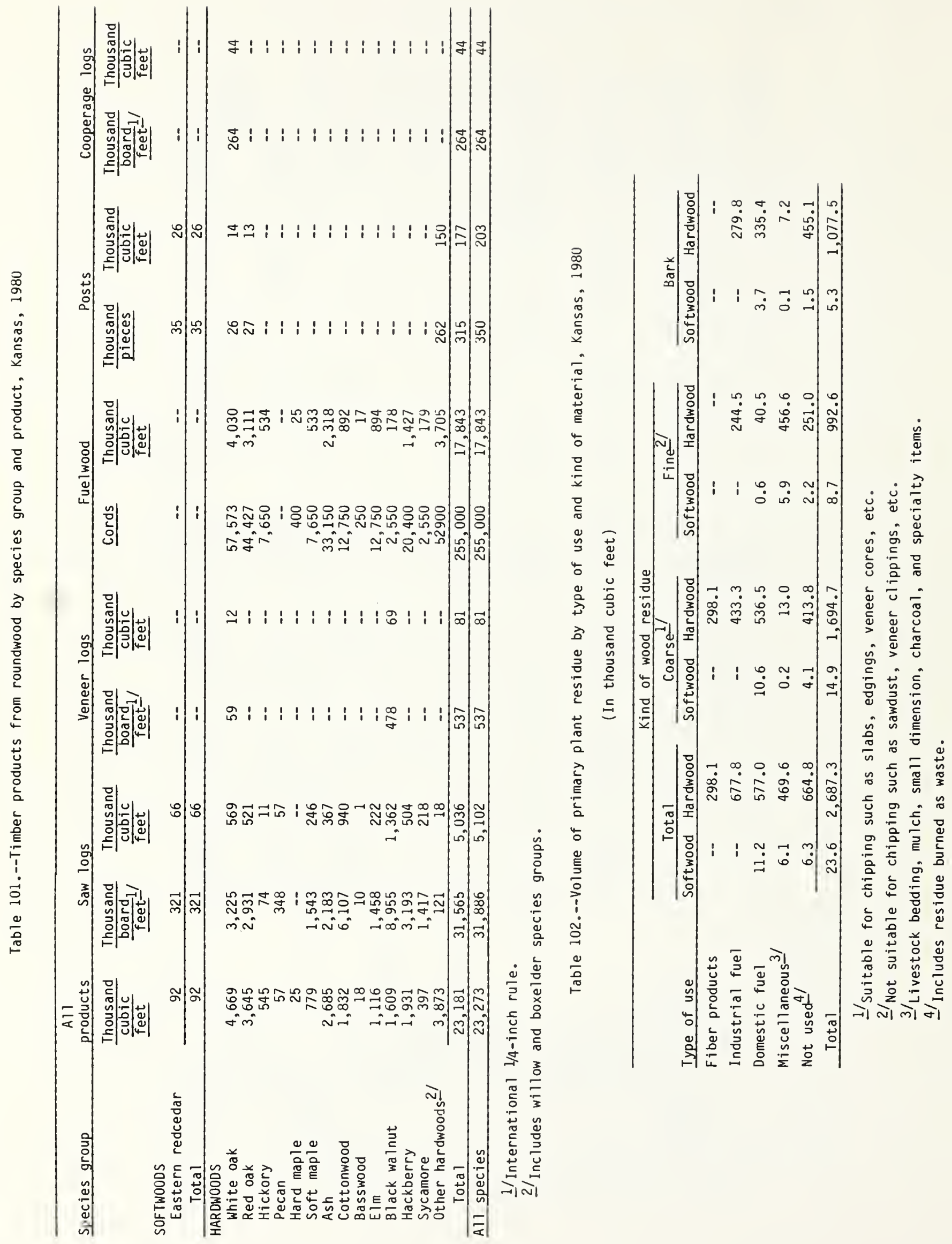




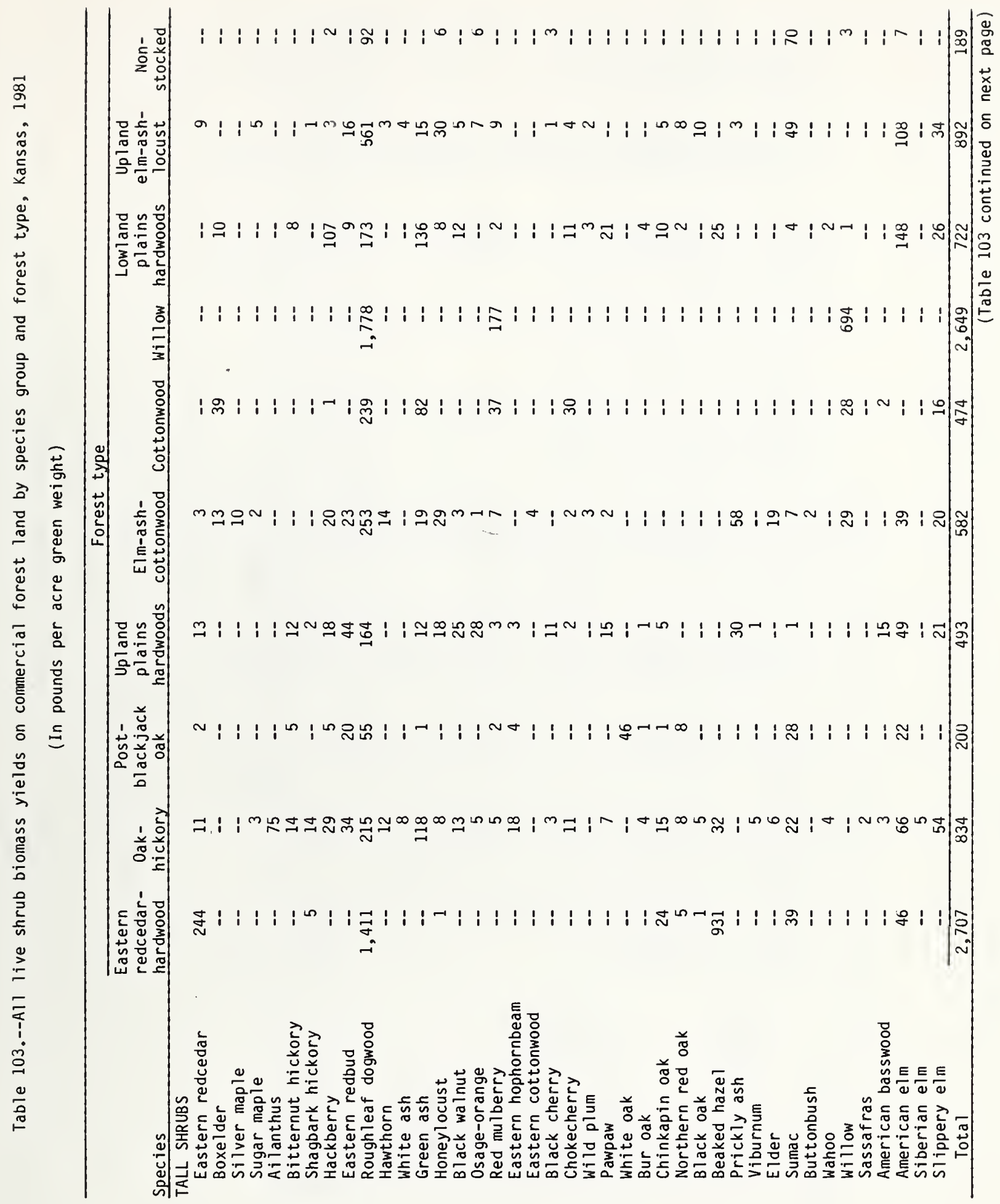




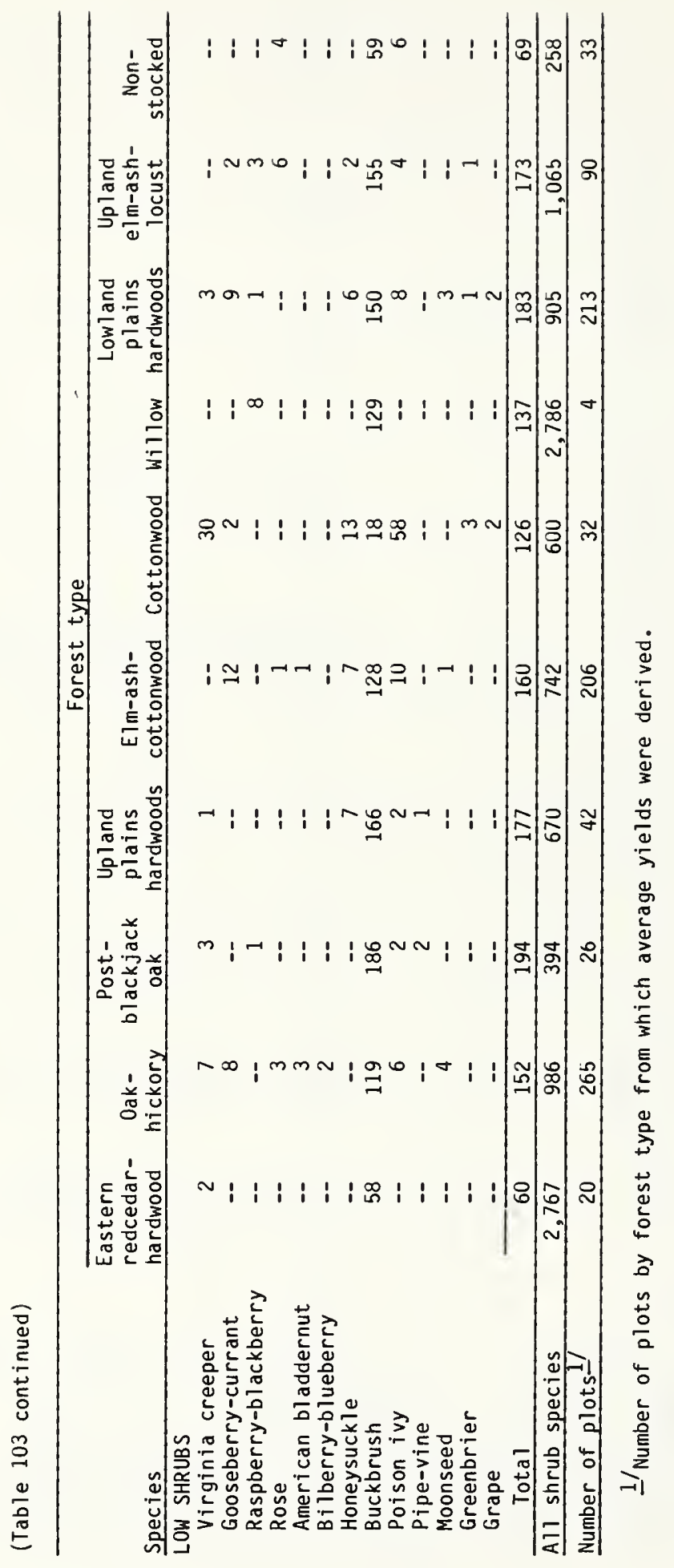




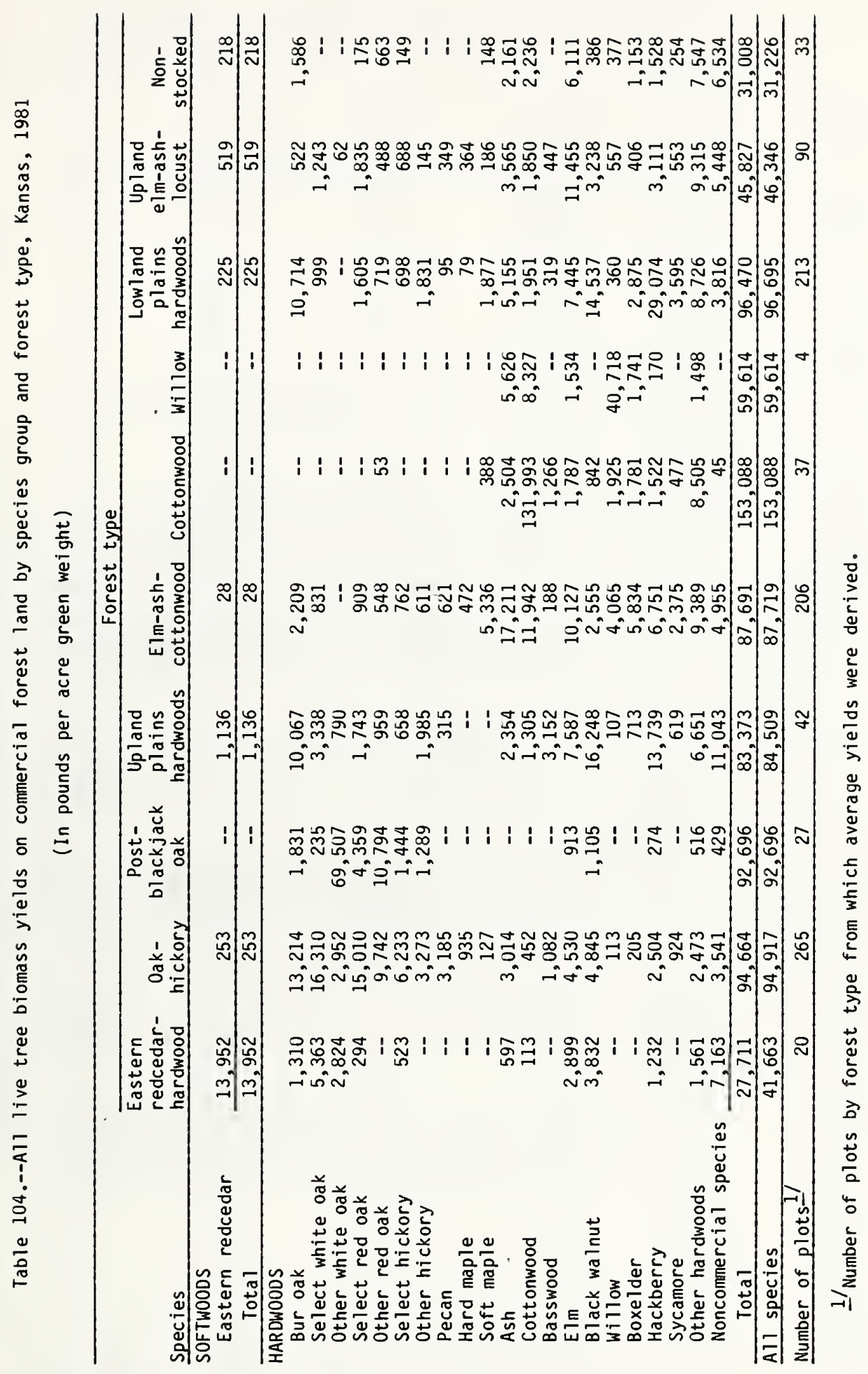




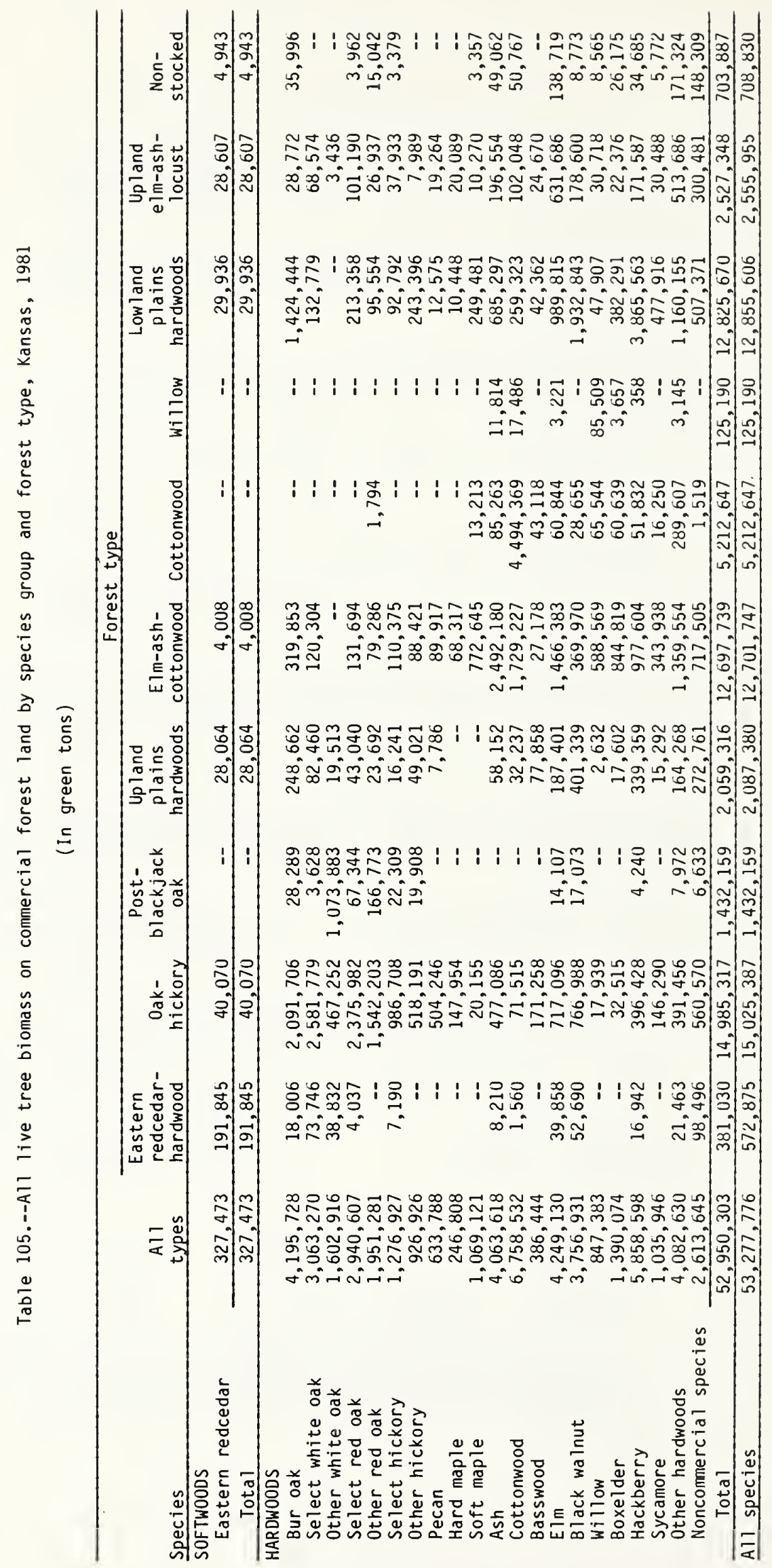


Table 106.--All live tree biomass weight by species group and tree biomass component, Kansas, 1981

(In green tons)

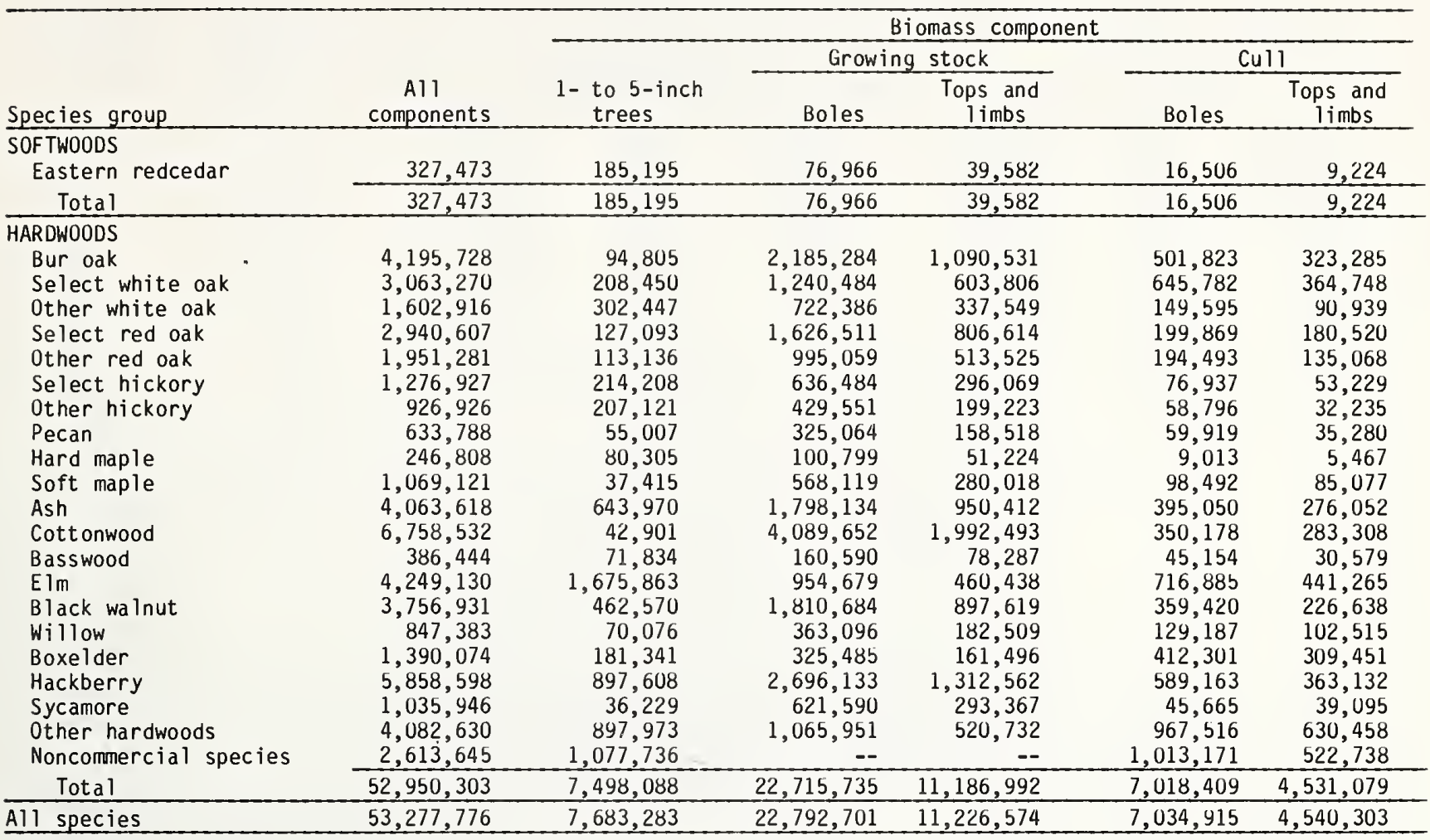

Table 107.--All live tree biomass volume by species group and tree biomass component, Kansas, 1981

(In thousand cubic feet)

\begin{tabular}{|c|c|c|c|c|c|c|}
\hline \multirow[b]{3}{*}{ Species group } & \multirow[b]{3}{*}{$\begin{array}{c}A 11 \\
\text { components }\end{array}$} & \multicolumn{5}{|c|}{ Biomass component } \\
\hline & & \multirow[b]{2}{*}{$\begin{array}{l}1-\text { to } 5 \text {-inch } \\
\text { trees }\end{array}$} & \multicolumn{2}{|c|}{ Growing stock } & \multicolumn{2}{|c|}{ Cul1 } \\
\hline & & & Boles & $\begin{array}{c}\text { Tops and } \\
\text { limbs }\end{array}$ & Boles & $\begin{array}{c}\text { Tops and } \\
\text { limbs }\end{array}$ \\
\hline \multicolumn{7}{|l|}{ SOFTWOODS } \\
\hline Eastern redcedar & 17,701 & 10,010 & 4,160 & 2,140 & 892 & 499 \\
\hline Total & 17,701 & 10,010 & 4,160 & 2,140 & 892 & 499 \\
\hline \multicolumn{7}{|l|}{ HARDWOODS } \\
\hline Bur oak & 368,784 & 34,164 & 179,043 & 89,298 & 40,528 & 25,751 \\
\hline Select white oak & 109,230 & 7,157 & 43,999 & 21,433 & 23,271 & 13,370 \\
\hline Other white oak & 56,862 & 10,384 & 25,633 & 11,992 & 5,449 & 3,404 \\
\hline Select red oak & 103,985 & 4,364 & 56,954 & 28,258 & 7,408 & 7,001 \\
\hline Other red oak & 68,077 & 3,829 & 34,501 & 17,850 & 6,940 & 4,957 \\
\hline Select hickory & 44,514 & 7,249 & 22,187 & 10,323 & 2,783 & 1,972 \\
\hline Other hickory & 32,220 & 7,009 & 15,003 & 6,961 & 2,087 & 1,160 \\
\hline Pecan & 27,992 & 2,290 & 14,413 & 7,030 & 2,677 & 1,582 \\
\hline Hard maple & 9,386 & 3,022 & 3,846 & 1,956 & 349 & 213 \\
\hline Soft maple & 46,315 & 1,615 & 24,462 & 12,060 & 4,322 & 3,856 \\
\hline Ash & 174,828 & 27,287 & 77,186 & 40,845 & 17,208 & 12,302 \\
\hline Cottonwood & 294,105 & 1,818 & 177,508 & 86,499 & 15,405 & 12,875 \\
\hline Basswood & 19,326 & 3,556 & 8,028 & 3,915 & 2,275 & 1,552 \\
\hline Elm & 167,526 & 65,145 & 37,546 & 18,117 & 28,636 & 18,082 \\
\hline Black walnut & 136,037 & 16,867 & 65,030 & 32,282 & 13,254 & 8,604 \\
\hline Willow & 36,529 & 2,917 & 15,540 & 7,815 & 5,658 & 4,599 \\
\hline Boxelder & 66,021 & 8,280 & 15,350 & 7,619 & 19,703 & 15,069 \\
\hline Hackberry & 250,191 & 37,361 & 115,285 & 56,136 & 25,467 & 15,942 \\
\hline Sycamore & 41,662 & 1,456 & 24,869 & 11,739 & 1,907 & 1,691 \\
\hline Other hardwoods & 174,256 & 37,481 & 45,228 & 22,111 & 41,738 & 27,698 \\
\hline Noncommercial species & 110,226 & 44,859 & -- & & 43,067 & 22,300 \\
\hline Total & $2,338,072$ & 328,110 & $1,001,611$ & 494,239 & 310,132 & 203,980 \\
\hline All species & $2,355,773$ & 338,120 & $1,005,771$ & 496,379 & 311,024 & 204,479 \\
\hline
\end{tabular}


Table 108.--Removals, $1 /$ net annual growth, and inventory of growing stock on commercial forest land, Kansas, 1981 and low removals option projections $2 /$ to 2011.

(In million cubic feet)

\begin{tabular}{lccc}
\hline & \multicolumn{3}{c}{ All species } \\
\cline { 2 - 4 } Year & Removals & Growth & Inventory \\
\hline 1981 & 14.0 & 23.2 & 711.3 \\
1991 & 16.0 & 32.2 & 845.8 \\
2001 & 21.1 & 35.0 & $1,001.7$ \\
2011 & 25.8 & 31.4 & $1,098.2$ \\
\hline
\end{tabular}

1/ Timber removals include volume "lost" due to land clearing, flooding, thinning, or changes in land use, in addition to timber cut and used.

2/Based on the following assumptions: (a) that the overall removals rate will be lower than that for the high removals option; (b) that the annual removals rates will differ for each 5-year period but that timber removals will increase at an average annual rate of 2.766 percent; (c) that the area of commercial forest land will decline but at an insignificant rate; (d) that radial growth will decline over time in relation to the increase of basal area per acre of trees; (e) that the intensity of forest management practised will continue at the rate indicated by recent trends; and (f) that the volume of "other" removals will drop during the period as more of these trees are utilized.

Table 109.--Removals, $1 /$ net annual growth, and inventory of growing stock on commercial forest land, Kansas, 1981 and high removals option projections 2 / to 2011 .

(In million cubic feet)

\begin{tabular}{lccc}
\hline & \multicolumn{3}{c}{ All species } \\
\cline { 2 - 4 } Year & Removals & Growth & Inventory \\
\hline 1981 & 14.0 & 23.2 & 711.3 \\
1991 & 18.7 & 32.1 & 830.8 \\
2001 & 27.2 & 35.5 & 944.7 \\
2011 & 37.2 & 34.4 & 969.3 \\
\hline
\end{tabular}

1/Timber removals include volume "lost" due to land clearing, flooding, thinning, or changes in land use, in addition to timber cut and used.

2/Based on the following assumptions: (a) that the overall removals rate will be higher than that for the low removals option; (b) that the annual removals rates will differ for each 5 -year period but that timber removals will increase at an average annual rate of 5.338 percent; (c) that the area of commercial forest land will decline but at an insignificant rate; (d) that radial growth will decline over time in relation to the increase of basal area per acre of trees; (e) that the intensity of forest management practised will continue at the rate indicated by recent trends; and (f) that the volume of "other" removals will drop during the period as more of these trees are utilized. 
Table 110.--Sampling errors-1/ for estimates smaller than the State totals $2 /$ of volume, net growth, removals, and area of commercial forest land, Kansas, 1981

\begin{tabular}{|c|c|c|c|c|c|c|c|}
\hline \multirow{2}{*}{$\begin{array}{l}\text { Sampling } \\
\text { error }\end{array}$} & \multirow{2}{*}{$\begin{array}{l}\text { Commercial } \\
\text { forest area }\end{array}$} & \multicolumn{3}{|c|}{ Growing Stock } & \multicolumn{3}{|c|}{ Sawtimber } \\
\hline & & Inventory & Growth & Removals & Inventory & Growth & Removals \\
\hline Percent & $\frac{\text { Thousand }}{\text { acres }}$ & $\cdots-\underline{M}$ & on cubi & et - - & -- Mil & on board & $t^{3}-\cdots$ \\
\hline 1 & $7,250.4$ & $8,813.5$ & 825.4 & $4,046.0$ & $46,135.7$ & $3,349.3$ & $21,493.3$ \\
\hline 2 & $1,812.6$ & $2,203.4$ & 206.3 & $1,011.5$ & $11,533.9$ & 837.3 & $5,373.3$ \\
\hline 3 & 805.6 & 979.3 & 91.7 & 449.6 & $5,126.2$ & 372.1 & $2,388.1$ \\
\hline 4 & 453.2 & 550.8 & 51.6 & 252.9 & $2,883.5$ & 209.3 & $1,343.3$ \\
\hline 5 & 290.0 & 352.5 & 33.0 & 161.8 & $1,845.4$ & 134.0 & 859.7 \\
\hline 10 & 72.5 & 88.1 & 8.3 & 40.5 & 461.4 & 33.5 & 214.9 \\
\hline 15 & 32.2 & 39.2 & 3.7 & 18.0 & 205.0 & 14.9 & 95.5 \\
\hline 20 & 18.1 & 22.0 & 2.1 & 10.1 & 115.3 & 8.4 & 53.7 \\
\hline 25 & 11.6 & 14.1 & 1.3 & 6.5 & 73.8 & 5.4 & 34.4 \\
\hline 50 & 2.9 & 3.5 & 0.3 & 1.6 & 18.5 & 1.3 & 8.6 \\
\hline 100 & 0.7 & 0.9 & 0.1 & 0.4 & 4.6 & 0.3 & 2.1 \\
\hline
\end{tabular}

$1 /$ At the 68-percent probability level.

2/Sampling errors for State totals are shown in the accuracy section of the Appendix.

3/ International $1 / 4$-inch rule.

Table 111.--Sampling errors $1 /$ for estimates smaller than the Survey Unit totals $2 /$ of volume, net growth, removals, and area of commercial forest land, Northeastern Survey Unit, Kansas, 1981

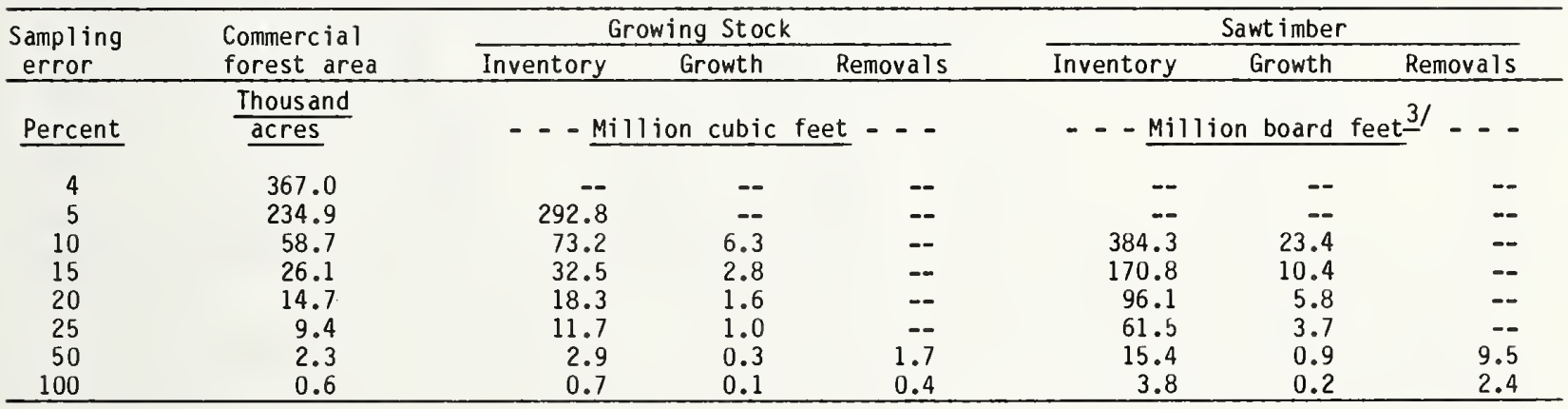

$1 /$ At the 68-percent probability level.

2/Sampling errors for Survey Unit totals are shown in the accuracy section of the Appendix. 3/International $1 / 4$-inch rule. 
Table 112.--Sampling errors $1 /$ for estimates smaller than the Survey Unit totals $2 /$ of volume, net growth, removals, and area of commercial forest 1and, Southeastern Survey Unit, Kansas, 1981

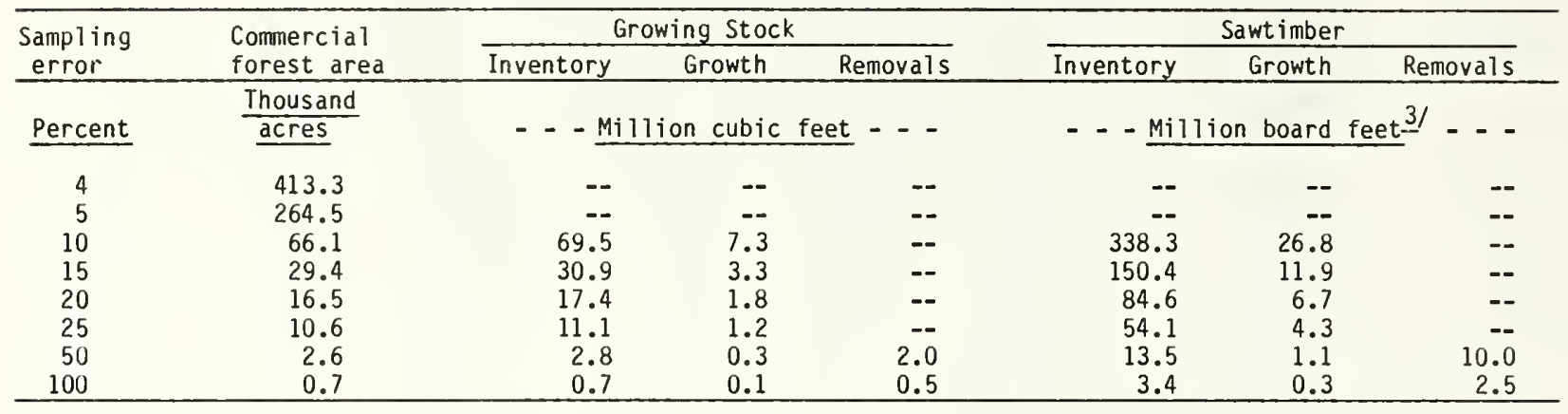

$1 /$ At the 68-percent probability level.

2/ Sampling errors for Survey Unit totals are shown in the accuracy section of the Appendix.

3/ International $1 / 4$-inch rule.

Table 113.--Sampling errors $1 /$ for estimates smaller than the Survey Unit totals $2 /$ of volume, net growth, removals, and area of commercial forest land, Western Survey Unit, Kansas, 1981

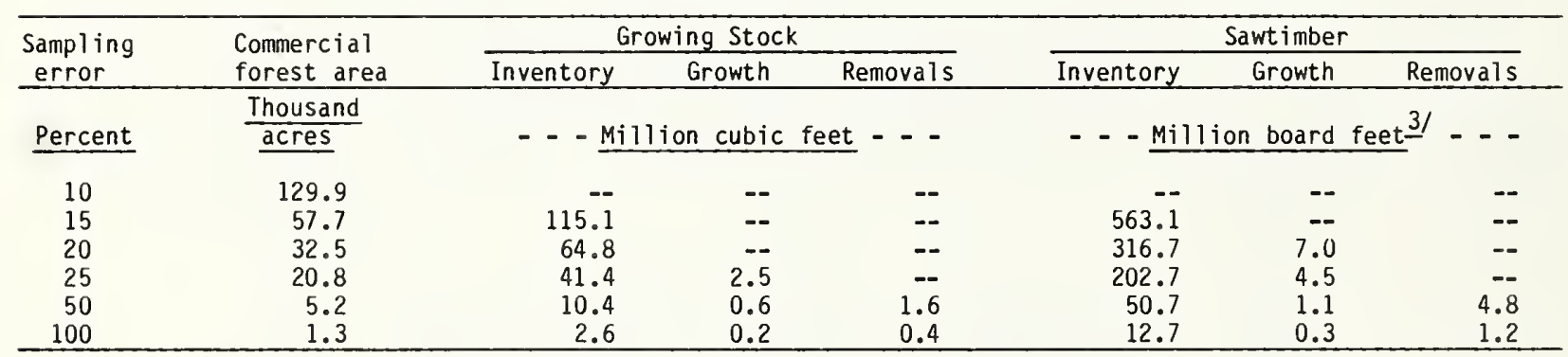

$1 /$ At the 68-percent probability level.

2/Sampling errors for Survey Unit totals are shown in the accuracy section of the Appendix. 3/International $1 / 4$-inch rule. 


Spencer, John S., Jr.; Strickler, John K.; Moyer, William J.

Kansas forest inventory, 1981. Resour. Bull. NC-83. St. Paul, MN: U.S. Department of Agriculture, Forest Service, North Central Forest Experiment Station; 1984. 134 p.

The third inventory of the timber resource of Kansas shows a 1.4percent increase in commercial forest area and a 42-percent gain in growing-stock volume between 1965 and 1980. Text and statistics are presented on area, volume, growth, mortality, removals, utilization, biomass, and future timber supply.

KEY WORDS: Area, timber volume, growth, mortality, removals. 
